Argonne

\title{
Annual Report of Groundwater Monitoring at Centralia, Kansas, in 2009
}

\section{Environmental Science Division}


About Argonne National Laboratory

Argonne is a U.S. Department of Energy laboratory managed by UChicago Argonne, LLC under contract DE-AC02-06CH11357. The Laboratory's main facility is outside Chicago, at 9700 South Cass Avenue, Argonne, Illinois 60439. For information about Argonne and its pioneering science and technology programs, see www.anl.gov.

\section{Availability of This Report}

This report is available, at no cost, at http://www.osti.gov/bridge. It is also available on paper to the U.S. Department of Energy and its contractors, for a processing fee, from:

U.S. Department of Energy

Office of Scientific and Technical Information

P.O. Box 62

Oak Ridge, TN 37831-0062

phone (865) 576-8401

fax (865) 576-5728

reports@adonis.osti.gov

\section{Disclaimer}

This report was prepared as an account of work sponsored by an agency of the United States Government. Reference herein to any specific commercial product, process, or service by trade name, trademark, manufacturer, or otherwise, does not necessarily constitute or imply its endorsement, recommendation, or favoring by the United States Government or any agency thereof. The views and opinions of document authors expressed herein do not necessarily state or reflect those of the United States Government or any agency thereof, Argonne National Laboratory, or UChicago Argonne, LLC. 


\section{Annual Report of Groundwater Monitoring at Centralia, Kansas, in 2009}

by

Applied Geosciences and Environmental Management Section

Environmental Science Division, Argonne National Laboratory

October 2010

USDA 


\section{Contents}

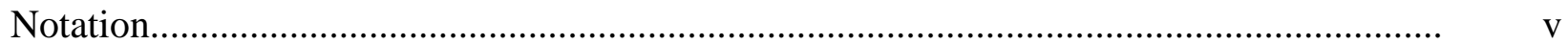

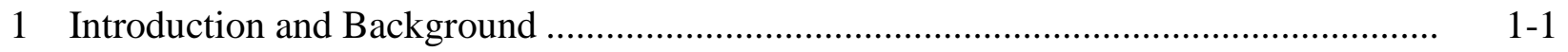

2 Sampling and Analysis Activities .........................................................................

2.1 Measurement of Groundwater Levels............................................................ 2-1

2.2 Monitoring Well and Piezometer Sampling and Analyses .................................. 2 2-1

2.3 Handling and Disposal of Investigation-Derived Waste ..................................... 2 2-2

2.4 Quality Control for Sample Collection, Handling, and Analysis ......................... 2 2-2

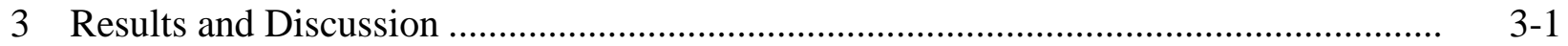

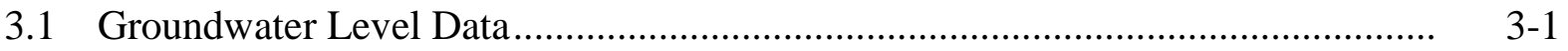

3.2 Groundwater Analysis Results................................................................. $3-2$

3.2.1 Sitewide Monitoring Results............................................................... 3-2

3.2.2 Monitoring Results for the IM Pilot Test Area ....................................... 3-3

4 Conclusions and Recommendations ...................................................................

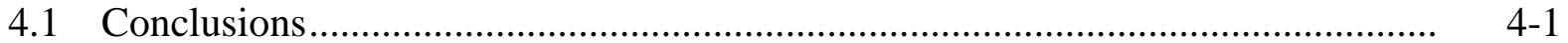

4.2 Recommendations ......................................................................................

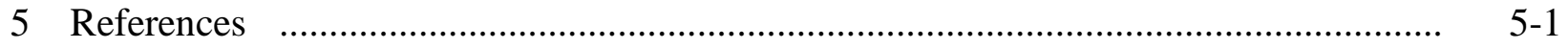

Appendix A: Sequence of Sampling Activities in 2009........................................... A-1

Appendix B: $\quad$ Waste Characterization and Disposal Documentation................................ B-1

Appendix C: Data Summaries for Verification VOCs Analyses by TestAmerica

Laboratories, Inc.

Appendix D: Time Series Diagrams for Selected Parameters at IM Monitoring Points..... D-1

\section{Tables}

3.1 Hand-measured water levels at Centralia in January, April, August, and October 2009

3.2 Analytical results from the AGEM laboratory for volatile organic compounds in groundwater samples collected from the sitewide monitoring points at Centralia, August 2004 to October 2009 
3.3 Field measurements for groundwater samples collected from the sitewide monitoring points at Centralia, August 2004 to October 2009

3.4 Analytical results from the AGEM laboratory for volatile organic compounds in groundwater samples collected from the IM pilot test monitoring points at Centralia, September 2008 to October 2009

3.5 Field measurements for groundwater samples collected from the IM pilot test monitoring points at Centralia, September 2008 to October 2009

A.1 Sequence of sampling activities at Centralia, April 2009 and October 2009

\section{Figures}

1.1 Approved sitewide monitoring network at Centralia, 2004 to 2008

1.2 Locations of IM pilot test injection points and post-injection groundwater monitoring points PMP1-PMP9.

1.3 Previously established (before the IM pilot test) sitewide monitoring points selected for continued annual sampling under the KDHE-approved interim monitoring plan

1.4 Pilot test monitoring points selected for continued annual or twice-yearly sampling under the KDHE-approved interim monitoring plan

3.1 Hydrographs summarizing results of long-term water level monitoring at Centralia, January 2008 to December 2009

3.2 Potentiometric surface at Centralia, based on water levels measured manually on August 27, 2009

3.3 Carbon tetrachloride levels in groundwater in the KDHE-approved network of sitewide monitoring wells sampled at Centralia in October 2009, with the interpreted lateral extent of the contaminant at intervals during the period August 2004 to October 2009

3.4 Carbon tetrachloride in groundwater samples collected during the pre-injection baseline sampling, September and November 2007

3.5 Field-measured results for DO in groundwater samples collected during the pre-injection baseline sampling, September and November 2007. 
3.6 Field-measured results for ORP in groundwater samples collected during the pre-injection baseline sampling, September and November 2007.

3.7 Analytical results for carbon tetrachloride in groundwater samples collected in October 2009 and September 2008 at the IM pilot test monitoring points

3.8 Field-measured results for DO in groundwater samples collected in October 2009 and September 2008 at the IM pilot test monitoring points.

3.9 Field-measured results for ORP in groundwater samples collected in October 2009 and September 2008 at the IM pilot test monitoring points

D.1 Analytical results for VOCs, DO, and ORP in groundwater samples collected at location MW02, November 2007 to October 2009.

D.2 Analytical results for VOCs, DO, and ORP in groundwater samples collected at location PMP1, January 2008 to October 2009

D.3 Analytical results for VOCs, DO, and ORP in groundwater samples collected at locations PSB2 and PMP2, November 2007 to October 2009

D.4 Analytical results for VOCs, DO, and ORP in groundwater samples collected at locations PSB3 and PMP3, November 2007 to October 2009

D.5 Analytical results for VOCs, DO, and ORP in groundwater samples collected at location PMP4, January 2008 to October 2009

D.6 Analytical results for VOCs, DO, and ORP in groundwater samples collected at locations PSB5 and PMP5, November 2007 to October 2009

D.7 Analytical results for VOCs, DO, and ORP in groundwater samples collected at locations PSB6 and PMP6, November 2007 to October 2009

D.8 Analytical results for VOCs, DO, and ORP in groundwater samples collected at locations PSB7 and PMP7, November 2007 to October 2009

D.9 Analytical results for VOCs, DO, and ORP in groundwater samples collected at locations PSB8 and PMP8, November 2007 to October 2009

D.10 Analytical results for VOCs, DO, and ORP in groundwater samples collected at locations PSB9 and PMP9, November 2007 to October 2009 


\section{Notation}

AGEM Applied Geosciences and Environmental Management

AMSL above mean sea level

BGL below ground level

${ }^{\circ} \mathrm{C} \quad$ degree(s) Celsius

CAS Corrective Action Study

CCC Commodity Credit Corporation

COC chain of custody

DO dissolved oxygen

EPA U.S. Environmental Protection Agency

$\mathrm{ft} \quad$ foot (feet)

IM interim measure

in. inch(es)

ISCR in situ chemical reduction

KDHE Kansas Department of Health and Environment

L liter(s)

$\mu \mathrm{g} / \mathrm{L} \quad$ microgram(s) per liter

$\mu \mathrm{S} / \mathrm{cm} \quad$ microsiemen(s) per centimeter

$\mathrm{mg} / \mathrm{L} \quad$ milligram(s) per liter

mi mile(s)

$\mathrm{mV} \quad$ millivolt(s)

ORP oxidation-reduction potential

RBSL risk-based screening level

TOC top of casing

USDA U.S. Department of Agriculture

VOC volatile organic compound 


\section{Annual Report of Groundwater Monitoring at Centralia, Kansas, in 2009}

\section{Introduction and Background}

In September 2005, periodic sampling of groundwater was initiated by the Commodity Credit Corporation of the U.S. Department of Agriculture (CCC/USDA) in the vicinity of a grain storage facility formerly operated by the CCC/USDA at Centralia, Kansas. The sampling at Centralia is being performed on behalf of the CCC/USDA by Argonne National Laboratory, in accord with a monitoring program approved by the Kansas Department of Health and Environment (KDHE). The objective is to monitor levels of carbon tetrachloride contamination identified in the groundwater at Centralia (Argonne 2003, 2004, 2005a).

Under the KDHE-approved monitoring plan (Argonne 2005b), the groundwater was sampled twice yearly from September 2005 until September 2007 for analyses for volatile organic compounds (VOCs), as well as measurement of selected geochemical parameters to aid in the evaluation of possible natural contaminant degradation (reductive dechlorination) processes in the subsurface environment. The results from the two-year sampling program demonstrated the presence of carbon tetrachloride contamination at levels exceeding the KDHE Tier 2 risk-based screening level (RBSL) of $5 \mu \mathrm{g} / \mathrm{L}$ for this compound in a localized groundwater plume that has shown little movement. The relative concentrations of chloroform, the primary degradation product of carbon tetrachloride, suggested that some degree of reductive dechlorination or natural biodegradation was talking place in situ at the former CCC/USDA facility on a localized scale.

The CCC/USDA subsequently developed an Interim Measure Conceptual Design (Argonne 2007b), proposing a pilot test of the Adventus EHC technology for in situ chemical reduction (ISCR). The proposed interim measure (IM) was approved by the KDHE in November 2007 (KDHE 2007). Implementation of the pilot test occurred in November-December 2007. The objective was to create highly reducing conditions that would enhance both chemical and biological reductive dechlorination in the injection test area (Argonne 2009a).

The KDHE (2008a) has requested that sitewide monitoring continue at Centralia until a final remedy has been selected (as part of a Corrective Action Study [CAS] evaluation) and implemented for this site. In response to this request, twice-yearly sampling of 10 monitoring wells and 6 piezometers (Figure 1.1) previously approved by the KDHE for monitoring of the 
groundwater at Centralia (KDHE 2005a,b) was continued in 2008. The sampling events under this extension of the two-year (2005-2007) monitoring program occurred in March and September 2008 (Argonne 2008b, 2009b). Additional piezometers specifically installed to evaluate the progress of the IM pilot test (PMP1-PMP9; Figure 1.2) were also sampled in 2008; the results of these analyses were reported and discussed separately (Argonne 2009a).

On the basis of results of the 2005-2008 sitewide monitoring and the 2008 IM pilot test monitoring, the CCC/USDA recommended a revised sampling program to address both of the continuing monitoring objectives until a CAS for Centralia is developed (Section 4.2 in Argonne 2009b). The elements of this interim monitoring plan are as follows:

- Annual sampling of

- Twelve previously established (before the pilot test) monitoring points (locations identified in Figure 1.3) and

- The five outlying pilot test monitoring points (PMP4, PMP5, PMP6, PMP7, PMP9; Figure 1.4).

- Sampling twice yearly at the five pilot test monitoring points inside the injection area (PMP1-PMP3, PMP8, MW02; Figure 1.4).

With the approval of the KDHE (2009), groundwater sampling for analyses of VOCs and selected other geochemical parameters was conducted at Centralia under the interim monitoring program outlined above in April and October 2009. This report documents the findings of the 2009 monitoring events. 


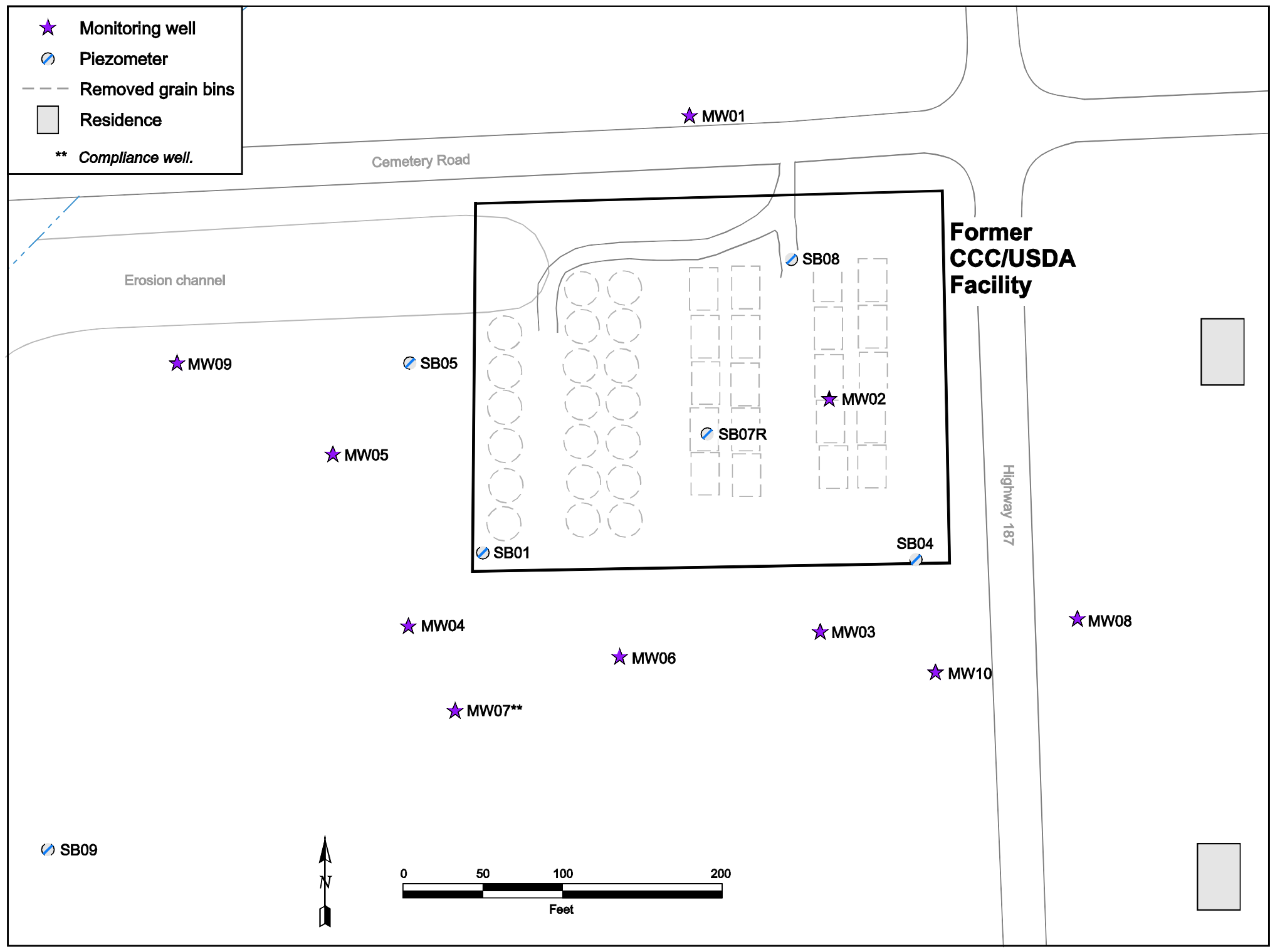

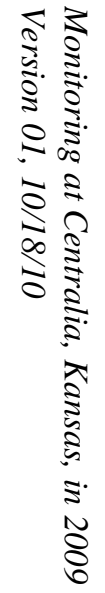

FIGURE 1.1 Approved sitewide monitoring network at Centralia, 2004 to 2008. 


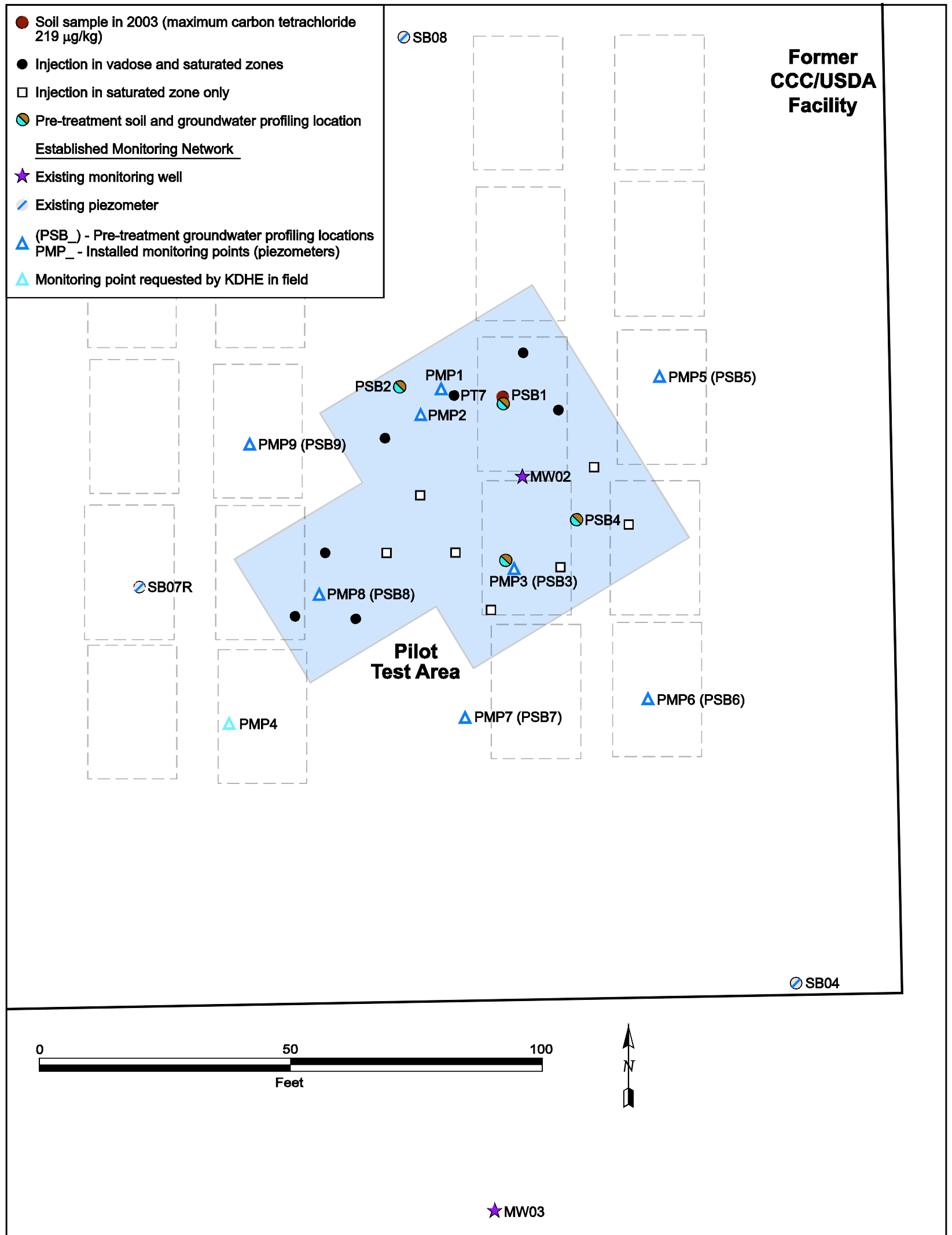

FIGURE 1.2 Locations of IM pilot test injection points and post-injection groundwater monitoring points PMP1-PMP9. 


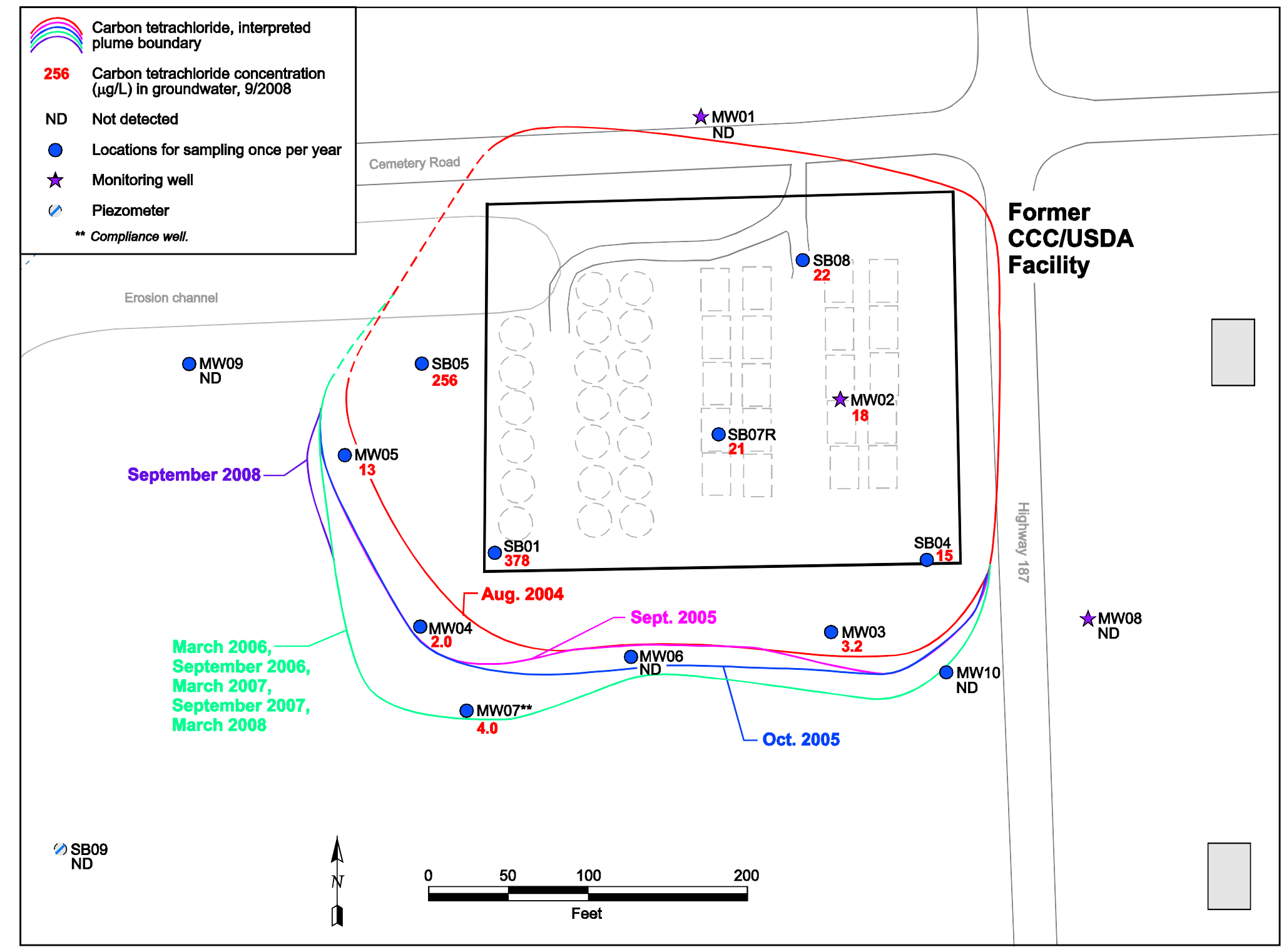

FIGURE 1.3 Previously established (before the IM pilot test) sitewide monitoring points selected for continued annual sampling under the KDHE-approved interim monitoring plan (Section 4.2 in Argonne 2009b). 


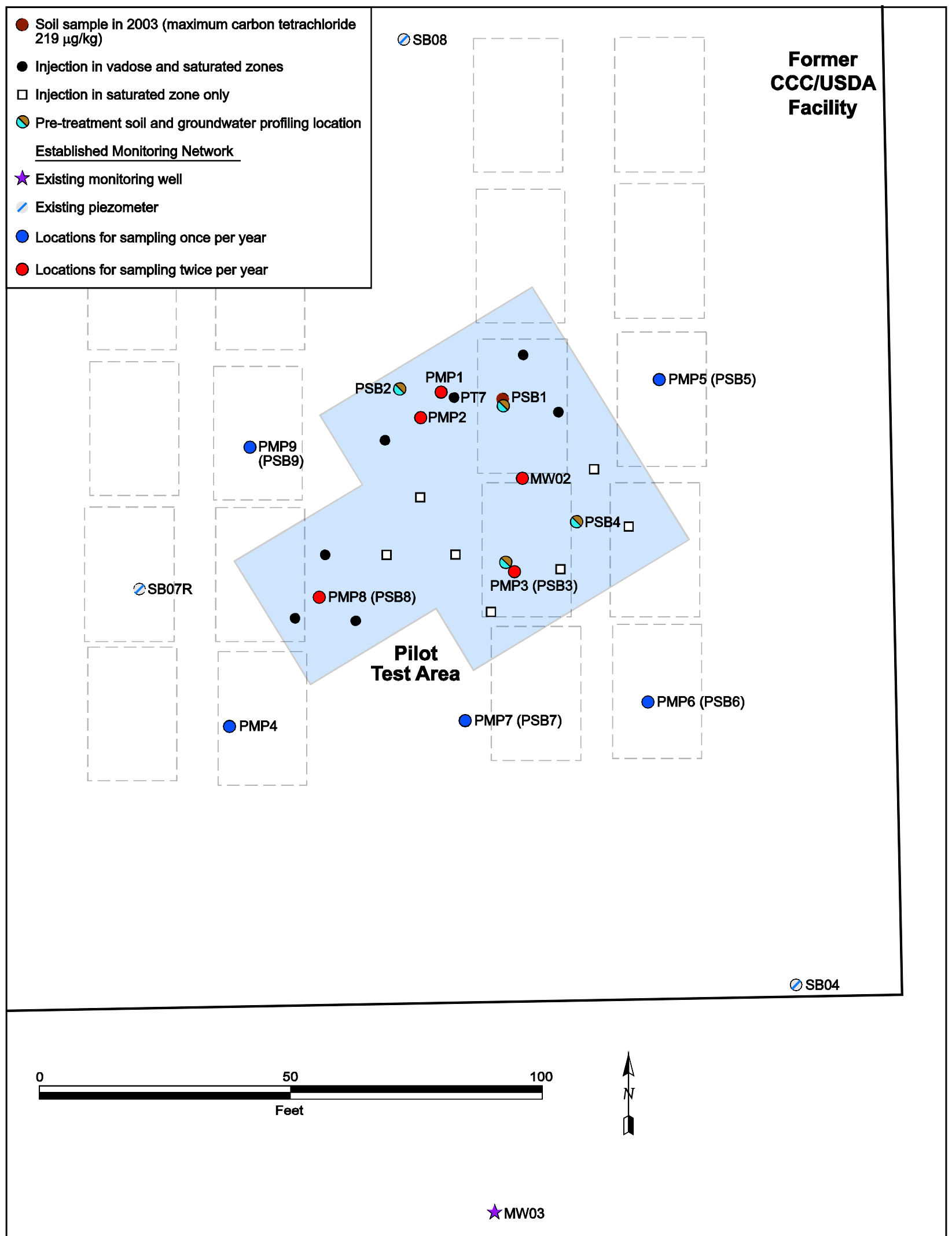

FIGURE 1.4 Pilot test monitoring points selected for continued annual or twice-yearly sampling under the KDHE-approved interim monitoring plan (Section 4.2 in Argonne 2009b). 


\section{Sampling and Analysis Activities}

\subsection{Measurement of Groundwater Levels}

Pilot test monitoring points PMP1-PMP3, PMP8, and MW02 (Figure 1.4) were sampled on April 22, 2009. Pilot test monitoring points PMP1-PMP9 and MW02 (Figure 1.4) and sitewide monitoring points MW03-MW07, MW09, MW10, SB01, SB04, SB05, SB07R, and SB08 (Figure 1.3) were sampled on October 6-8, 2009. Before each well or piezometer was sampled, a water level indicator was used to measure the depth to groundwater and the total depth of each well from the top of the well casing.

Downhole pressure sensors equipped with automatic data loggers are currently installed in wells MW01 and MW03-MW06 to gather long-term data on the groundwater elevation and gradient at Centralia. The recorded water level data for the 2009 observation period were retrieved from the loggers on January 21 and August 27, 2009, and on April 28, 2010. Water levels were measured manually during the current (2009) review period in selected wells in conjunction with the data downloads on January 21 and August 27, 2009.

The groundwater level data are presented and discussed in Section 3.1.

\subsection{Monitoring Well and Piezometer Sampling and Analyses}

After measurement of water levels, each monitoring point was purged of a small volume by using a bladder pump or a Waterra pump. With the approval of the KDHE (2008b), the purging was performed by using low-flow techniques in accord with U.S. Environmental Protection Agency (EPA) procedure EPA/540/S-95/504 (Puls and Barcelona 1996) and the equipment manufacturers' instructions. Field measurements of temperature, $\mathrm{pH}$, conductivity, dissolved oxygen (DO), and oxidation reduction potential (ORP) were taken during purging until the measurements stabilized. Field measurements of iron(II) and carbon dioxide were made as outlined in the (2005-2007) monitoring plan (Argonne 2005b), in accord with procedures in the Master Work Plan (Argonne 2002). The sequence of activities during each of the 2009 sampling events (in April and October) is summarized in Appendix A.

Groundwater samples designated for VOCs analyses were collected in appropriate laboratory containers, labeled, packaged, and chilled to $4^{\circ} \mathrm{C}$ by placement in ice-filled coolers. 
The samples were shipped by an overnight delivery service to the Applied Geosciences and Environmental Management (AGEM) Laboratory at Argonne for VOCs analyses by EPA Method 524.2 (EPA 1995). Aliquots of selected samples (chosen in the field) were also shipped to TestAmerica Laboratories, Inc., South Burlington, Vermont, for verification VOCs analyses.

The analytical results for groundwater samples are discussed in Section 3.2.

\subsection{Handling and Disposal of Investigation-Derived Waste}

The small volumes of purge water generated during each of the 2009 sampling events (April and October) were containerized on-site. Samples of the combined waters were analyzed by a KDHE-certified laboratory (Pace Analytical Services, Inc., Lenexa, Kansas) and found to be free of carbon tetrachloride, chloroform, 1,2 dibromoethane, and nitrate at levels exceeding the KDHE Tier 2 RBSL values for these compounds. With the approval of the KDHE, the accumulated purge water was taken to the Sabetha, Kansas, publicly owned treatment works on November 18, 2009, for disposal. Documentation of the purge water analyses and disposal is in Appendix B.

\subsection{Quality Control for Sample Collection, Handling, and Analysis}

Quality assurance/quality control procedures followed during the April and October 2009 monitoring events are described in detail in the Master Work Plan (Argonne 2002). The results are summarized as follows:

- Sample collection and handling activities were monitored by the documentation of samples as they were collected and the use of chain-of-custody forms and custody seals to ensure sample integrity during handling and shipment.

- Samples designated for VOCs analyses were received with custody seals intact and at the appropriate preservation temperature. All samples were analyzed within the required holding times.

- Quality control samples collected to monitor sample collection and handling activities included equipment rinsates and trip blanks. In addition, method blanks 
were analyzed with the samples to monitor analytical methodologies. All quality control samples analyzed at the AGEM Laboratory were free of carbon tetrachloride and chloroform contamination.

- Groundwater samples were analyzed for VOCs at the AGEM Laboratory with the purge-and-trap method on a gas chromatograph-mass spectrometer system. Calibration checks with each sample delivery group were required to be within $\pm 20 \%$ of the standard. Surrogate standard determinations performed on samples and blanks were within the specified range of $80-120 \%$ for all samples, in either the initial analysis or a successful reanalysis.

- In accordance with the quality control procedures defined in the Master Work Plan (Argonne 2002), the analyses of water samples at the AGEM Laboratory were verified by a second laboratory. Two groundwater samples collected during the April 2009 monitoring event (from MW02 and PMP8) and three samples from the October 2009 event (from MW05, MW10, and PMP8) were submitted for verification organic analysis according to EPA Contract Laboratory Program methodology by TestAmerica. Results showed good agreement over the range of contaminant concentrations detected, with average relative percent difference values of $24 \%$ for carbon tetrachloride and $11 \%$ for chloroform. The detection of methylene chloride, a secondary dechlorination by-product of carbon tetrachloride, was confirmed in the verification analyses. Summary pages for the verification organic analyses by TestAmerica for the samples collected on April 22 and October 6-8, 2009 are in Appendix C. 


\section{Results and Discussion}

\subsection{Groundwater Level Data}

Depths to groundwater were measured manually in each of the wells sampled during the monitoring events on April 22 and October 6-8, 2009. Water levels were also measured manually in conjunction with the data logger downloads performed during the current (2009) review period on January 21 and August 27, 2009. The hand-measured water level data are in Table 3.1.

Hydrographs depicting the variations in water levels in monitored wells MW01 and MW03-MW06 during the current (2009) and previous (2008) review periods are in Figure 3.1. The data logger that was formerly in well MW02 was removed in January 2008 because of corrosion, and its trace appears only briefly in Figure 3.1. The water level traces are shown in conjunction with daily precipitation data obtained from the Kansas State University recording weather station in Powhattan, Kansas, approximately $26 \mathrm{mi}$ east of Centralia (http://wdl.agron.ksu.edu/). Figure 3.1 indicates that the groundwater levels at Centralia have fluctuated by approximately 2-4 ft in response to both seasonal and shorter-term rainfall events but showed little net change in 2008-2009. The pronounced, transient water level "spikes" indicated in the hydrograph for monitoring well MW06 are believed to reflect localized flooding at the location of this (flush-mounted) monitoring well that occurs during heavy rainfall events, particularly in the spring and early summer.

The potentiometric surface at Centralia, interpreted from manual measurements on August 27, 2009, is depicted in Figure 3.2. The recent results are consistent with previous measurements (Argonne 2006, 2007a, 2008a,b, 2009b), indicating an apparent groundwater flow direction toward the southwest across much of the former CCC/USDA facility. Like previous depictions of the potentiometric surface, Figure 3.2 indicates that groundwater flow appears focused toward a localized low in the potentiometric surface, defined by the water level measurements at SB01, MW04, MW06, and MW07. Argonne's earlier investigations (Argonne 2003, 2004) suggested that the increased hydraulic gradients observed near these wells are a reflection of relatively low-permeability silts and clays that compose the aquifer unit in this portion of the study area, in comparison to the coarser-grained deposits identified in the northern and eastern portions of the site. The results of the sitewide groundwater analyses discussed in Section 3.2.1 support an interpretation of slow groundwater flow (and carbon tetrachloride migration) to the south-southwest, in keeping with the observed water level patterns. 


\subsection{Groundwater Analysis Results}

As outlined in Section 1, groundwater sampling and VOCs analyses were conducted from 2005 to 2008 in a network of 16 monitoring points (Figures 1.1) distributed across the investigation area at Centralia. The data from these locations were used to track the natural changes in the concentrations and areal extent of the carbon tetrachloride contamination in groundwater. In October 2009, groundwater sampling was performed, with the approval of the KDHE (2009), in a more limited suite of 12 monitoring points (Figure 1.3) to continue sitewide monitoring of the carbon tetrachloride distribution at Centralia.

In January 2008, 9 additional piezometers (PMP1-PMP9; Figure 1.2) were installed to facilitate more detailed monitoring of the effects of the ISCR treatment technology on the groundwater geochemistry and contaminant distribution in the immediate vicinity of the IM pilot test injection area (Argonne 2009a). Sampling for further assessment of the impacts of the ISCR pilot treatment was conducted in April and October 2009, in accord with the interim monitoring plan (Section 4.2 in Argonne 2009b).

The results of these monitoring efforts are summarized, respectively, in Section 3.2.1 and Section 3.2.2.

\subsubsection{Sitewide Monitoring Results}

The analytical data for VOCs in the groundwater samples collected in the network of sitewide monitoring wells in October 2009 are in Table 3.2, together with data for the previous sampling events at Centralia since sampling of the monitoring wells began in 2004. The October 2009 data for carbon tetrachloride are illustrated in Figure 3.3, along with the lateral margins of the contaminant distribution, as interpreted on the basis of each of the sitewide groundwater sampling events summarized in Table 3.2.

Carbon tetrachloride was detected in October 2009 at 9 of the 12 approved sitewide monitoring locations (KDHE 2009) on and downgradient from the former CCC/USDA facility (Figure 3.3), at concentrations ranging from $2.9 \mu \mathrm{g} / \mathrm{L}$ (at MW04) to a maximum of $396 \mu \mathrm{g} / \mathrm{L}$ (at SB01). Chloroform concentrations ranging from $<1 \mu \mathrm{g} / \mathrm{L}$ to $19 \mu \mathrm{g} / \mathrm{L}$ were detected at 7 of the 12 sampled locations (Table 3.2). 
The carbon tetrachloride concentrations identified in the sitewide monitoring wells in October 2009 were generally consistent with previous measurements; however, the concentrations at all of the sampled points having detectable carbon tetrachloride showed a slight increase relative to the most recent previous (September 2008) monitoring results. The data in Table 3.2 and Figure 3.3 continue to indicate the longer-term trends (observed previously) of slightly increasing carbon tetrachloride levels at monitoring points SB05, MW03, MW04, and MW07, along the western and southern margins of the groundwater plume and in the apparent direction of groundwater flow.

The results of field measurements on the groundwater samples from wells in the sitewide monitoring network are summarized in Table 3.3. The detection of trace to relatively low levels of chloroform in association with the carbon tetrachloride identified at monitoring points MW05, MW07, SB01, SB04, SB05, SB07R, and SB08 (Table 3.2) suggests that some degradation of carbon tetrachloride is occurring at these locations. With only one possible exception (at MW06), however, the relatively high DO concentrations (1.42-9.66 mg/L) and positive ORP levels (53 mV to $238 \mathrm{mV}$ ) identified at the sitewide monitoring points (Table 3.3) do not support the widespread occurrence of anaerobic reducing conditions within the Centralia aquifer.

\subsubsection{Monitoring Results for the IM Pilot Test Area}

Baseline groundwater sampling was conducted within and adjacent to the IM pilot test area (Figure 1.2) in September and November 2007, prior to the injection of the ISCR materials, to provide a basis for assessment of the ISCR treatment technology over time. The pre-treatment concentrations of carbon tetrachloride and the values of DO and ORP identified during this sampling (Argonne 2009a) are illustrated in Figures 3.4-3.6, respectively.

Injection of the ISCR materials (in December 2007) initially generated extremely reducing, oxygen-depleted groundwater conditions (conducive to the reductive dechlorination of carbon tetrachloride) within the injection field, while less dramatic reductions in DO and ORP were observed at monitoring points outside the treatment area. The extremely low DO and ORP levels were, however, maintained for only approximately 5-7 weeks after injection. Subsequent monitoring in 2008 (Argonne 2009a,b) demonstrated that the DO and ORP levels within the injection field remained consistently lower than those at monitoring points outside the injection area, but the results showed no clear indication of further geochemical effects beyond the limits of the injection field. 
Reductions of $96-99 \%$ in the concentrations of carbon tetrachloride in groundwater within the injection field and of $20-70 \%$ at most monitoring points near the injection area were observed in the first 5-7 weeks after injection. Continued monitoring in 2008 showed that carbon tetrachloride concentrations in the injection field generally remained near the initial postinjection levels or decreased slightly more, while the concentrations at points bordering or outside the injection area showed little consistency and variably decreased, increased, or remained relatively unchanged (Argonne 2009a) after the initial 5-7 weeks following the injection.

The analytical data for VOCs in the groundwater samples collected from the IM pilot test monitoring points (PMP1-PMP9 and MW02; Figure 1.4) in April and October 2009 are in Table 3.4, together with data for the most recent previous sampling event (September 2008) at these locations. The corresponding field measurements for these locations and sampling events are in Table 3.5. Time series diagrams summarizing the complete sequence of analysis results for selected parameters (carbon tetrachloride, chloroform, methylene chloride, DO, ORP) at each IM monitoring point since the ISCR pilot test was implemented in November 2007 are in Appendix D, Figures D.1-D.10.

Carbon tetrachloride was detected at each of the points sampled in the pilot test area during the April and October 2009 monitoring events, except for monitoring well MW02 (Table 3.4). In April 2009, carbon tetrachloride concentrations ranging from $3.2 \mu \mathrm{g} / \mathrm{L}$ to 1,398 $\mu \mathrm{g} / \mathrm{L}$ were identified at PMP1-PMP3 and PMP8. In October 2009, concentrations ranging from $<1 \mu \mathrm{g} / \mathrm{L}$ (at PMP3) to 1,384 $\mu \mathrm{g} / \mathrm{L}$ (at PMP2) were detected at piezometers PMP1-PMP9.

The results of the September 2008 and October 2009 analyses for carbon tetrachloride are illustrated in Figure 3.7. The data indicate that, except for location PMP1, the carbon tetrachloride concentrations in groundwater in the pilot test injection field (shaded area in Figure 3.8) continued to decrease during the 2009 review period. This observation is qualitatively consistent with the DO concentrations and ORP levels identified in the pilot test area in 2009 (Table 3.5 and Figures 3.8 and 3.9, respectively), which indicate that oxygendepleted, chemically reducing conditions were maintained in the injection field throughout the present review period.

Relatively high and persistent levels of chloroform (relative to carbon tetrachloride; Table 3.4 and Appendix D) were also observed at PMP1-PMP9 during the current review period, 
and low levels of methylene chloride were detected at four of the pilot test monitoring locations (PMP2, PMP5, PMP7, PMP8) in the October 2009 sampling event. Together, these findings confirm that geochemical conditions favorable to the degradation of carbon tetrachloride, via reductive dechlorination, persist in the pilot test area as a result of the November 2007 ISCR injections.

Figures 3.8 and 3.9 indicate that DO and ORP values decreased from September 2008 to October 2009 at monitoring points PMP4, PMP7, and PMP9 to the southwest and downgradient of the pilot test injection field, and also at nearby point PMP6 (to the southeast). Slightly lower concentrations of carbon tetrachloride were also identified at the PMP4 and PMP7 locations in October 2009 (Figure 3.7). These relationships are empirically consistent with possible slow expansion of the range of influence of the ISCR treatment technology with time. Additional monitoring in the pilot test area will be necessary, however, to substantiate these observations, as increased carbon tetrachloride concentrations were observed in the apparent direction of groundwater flow at PMP9 and nearby monitoring point SB07R (see Section 3.2.1 and Table 3.2) during the current review period, as well as at PMP6 and more upgradient monitoring points PMP1 and PMP5. 
TABLE 3.1 Hand-measured water levels at Centralia in January, April, August, and October 2009.

\begin{tabular}{|c|c|c|c|c|c|c|c|c|c|}
\hline \multirow[b]{2}{*}{ Well } & \multirow[b]{2}{*}{$\begin{array}{c}\text { Top of Casing } \\
\text { Elevation }^{\mathrm{b}} \\
\text { (ft AMSL) }\end{array}$} & \multicolumn{2}{|c|}{ January 21, 2009} & \multicolumn{2}{|c|}{ April $22,2009^{a}$} & \multicolumn{2}{|c|}{ August 27, 2009} & \multicolumn{2}{|c|}{ October $6-8,2009^{a}$} \\
\hline & & $\begin{array}{l}\text { Depth to } \\
\text { Groundwater } \\
\text { (ft TOC) }\end{array}$ & $\begin{array}{l}\text { Groundwater } \\
\text { Elevation } \\
\text { (ft AMSL) }\end{array}$ & $\begin{array}{l}\text { Depth to } \\
\text { Groundwater } \\
\text { (ft TOC) }\end{array}$ & $\begin{array}{l}\text { Groundwater } \\
\text { Elevation } \\
\text { (ft AMSL) }\end{array}$ & $\begin{array}{l}\text { Depth to } \\
\text { Groundwater } \\
\text { (ft TOC) }\end{array}$ & $\begin{array}{l}\text { Groundwater } \\
\text { Elevation } \\
\text { (ft AMSL) }\end{array}$ & $\begin{array}{l}\text { Depth to } \\
\text { Groundwater } \\
\text { (ft TOC) }\end{array}$ & $\begin{array}{l}\text { Groundwater } \\
\text { Elevation } \\
\text { (ft AMSL) }\end{array}$ \\
\hline MW01 & 1329.17 & 13.19 & 1315.98 & & & 11.35 & 1317.82 & 10.31 & 1318.86 \\
\hline MW02 & 1334.67 & & & 20.8 & 1313.87 & 20.07 & 1314.60 & 20.98 & 1313.69 \\
\hline MW03 & 1334.51 & 21.37 & 1313.14 & & & 19.93 & 1314.58 & 20.43 & 1314.08 \\
\hline MW04 & 1322.57 & 24.53 & 1298.04 & & & 22.92 & 1299.65 & 23.75 & 1298.82 \\
\hline MW05 & 1317.97 & 10.44 & 1307.53 & & & 8.15 & 1309.82 & 11.98 & 1305.99 \\
\hline MW06 & 1329.63 & 36.80 & 1292.83 & & & 35.15 & 1294.48 & 36.23 & 1293.40 \\
\hline MW07 & 1324.76 & & & & & 26.48 & 1298.28 & 27.97 & 1296.79 \\
\hline MW08 & 1332.34 & & & & & 17.77 & 1314.57 & 18.85 & 1313.49 \\
\hline MW09 & 1310.41 & & & & & 0.47 & 1309.94 & 3.92 & 1306.49 \\
\hline MW10 & 1334.39 & & & & & 19.75 & 1314.64 & 20.59 & 1313.80 \\
\hline SB01 & 1325.15 & & & & & 17.76 & 1307.39 & 17.42 & 1307.73 \\
\hline SBO4 & 1335.67 & & & & & 21.02 & 1314.65 & 21.73 & 1313.94 \\
\hline SB05 & 1321.28 & & & & & 9.11 & 1312.17 & 11.12 & 1310.16 \\
\hline SB07R & 1331.57 & & & & & 16.91 & 1314.66 & 18.43 & 1313.14 \\
\hline SB08 & 1332.48 & & & & & 17.83 & 1314.65 & 18.51 & 1313.97 \\
\hline SB09 & 1311.07 & & & & & 4.82 & 1306.25 & 7.32 & 1303.75 \\
\hline PMP1 & 1333.70 & & & 20.0 & 1313.70 & & & 21.08 & 1312.62 \\
\hline PMP2 & 1333.67 & & & 20.0 & 1313.67 & & & 19.84 & 1313.83 \\
\hline PMP3 & 1334.57 & & & 22.4 & 1312.17 & & & 21.15 & 1313.42 \\
\hline PMP4 & 1331.99 & & & & & & & 18.59 & 1313.40 \\
\hline PMP5 & 1335.07 & & & & & & & 21.73 & 1313.34 \\
\hline PMP6 & 1335.19 & & & & & & & 21.53 & 1313.66 \\
\hline PMP7 & 1334.06 & & & & & & & 20.54 & 1313.52 \\
\hline PMP8 & 1332.94 & & & 19.4 & 1313.54 & & & 19.87 & 1313.07 \\
\hline PMP9 & 1331.83 & & & & & & & 15.83 & 1316.00 \\
\hline
\end{tabular}

a Measurements made during sampling.

b 2009 surveyed elevations.

c Depths measured from the top of the casing (TOC). 
TABLE 3.2 Analytical results from the AGEM Laboratory for volatile organic compounds in groundwater samples collected at the sitewide monitoring points at Centralia, August 2004 to October 2009.

\begin{tabular}{|c|c|c|c|c|c|c|}
\hline \multirow[b]{2}{*}{ Well } & \multirow{2}{*}{$\begin{array}{l}\text { Screen } \\
\text { Interval } \\
\text { (ft BGL) }\end{array}$} & \multirow[b]{2}{*}{ Sample } & \multirow[b]{2}{*}{$\begin{array}{l}\text { Sample } \\
\text { Date }\end{array}$} & \multicolumn{3}{|c|}{ Concentration $^{\mathrm{a}}(\mu \mathrm{g} / \mathrm{L})$} \\
\hline & & & & $\begin{array}{c}\text { Carbon } \\
\text { Tetrachloride }\end{array}$ & Chloroform & $\begin{array}{c}\text { Methylene } \\
\text { Chloride }\end{array}$ \\
\hline \multirow[t]{9}{*}{ MW01 } & $54.5-64.5$ & CNMW01-W-16158 & $8 / 24 / 04$ & $N D^{b}$ & ND & ND \\
\hline & & CNMW01-W-19276 & 9/10/05 & ND & ND & ND \\
\hline & & CNMW01-W-16308 & $10 / 11 / 05$ & ND & ND & ND \\
\hline & & CNMW01-W-19890 & $3 / 15 / 06$ & ND & ND & ND \\
\hline & & CNMW01-W-22501 & $9 / 25 / 06$ & ND & ND & ND \\
\hline & & CNMW01-W-16326 & $3 / 29 / 07$ & ND & ND & ND \\
\hline & & CNMW01-W-16228 & $9 / 26 / 07$ & $1.0 \mathrm{R}^{\mathrm{c}}$ & ND & ND \\
\hline & & CNMW01-W-26023 & $3 / 19 / 08$ & ND & ND & ND \\
\hline & & CNMW01-W-26673 & $9 / 9 / 08$ & ND & ND & ND \\
\hline \multirow[t]{7}{*}{$\mathrm{MWO}^{\mathrm{d}}$} & $49.5-59.5$ & CNMW02-W-16159 & $8 / 26 / 04$ & 215 & 6.2 & ND \\
\hline & & CNMW02-W-19282 & 9/11/05 & 776 & 33 & ND \\
\hline & & CNMW02-W-16309 & $10 / 12 / 05$ & 528 & 21 & ND \\
\hline & & CNMW02-W-19908 & $3 / 16 / 06$ & 847 & 21 & ND \\
\hline & & CNMW02-W-22508 & $9 / 26 / 06$ & 1233 & 25 & ND \\
\hline & & CNMW02-W-15489 & $3 / 26 / 07$ & 829 & 14 & ND \\
\hline & & CNMW02-W-16227 & $9 / 26 / 07$ & 1138 & 18 & ND \\
\hline \multirow[t]{10}{*}{ MW03 } & $50.5-60.5$ & CNMW03-W-16178 & $8 / 24 / 04$ & 1.2 & ND & ND \\
\hline & & CNMW03-W-19277 & $9 / 10 / 05$ & 1.6 & ND & ND \\
\hline & & CNMW03-W-16310 & $10 / 11 / 05$ & 1.8 & ND & ND \\
\hline & & CNMW03-W-19909 & $3 / 17 / 06$ & 2.6 & $0.2 \mathrm{~J}^{\mathrm{e}}$ & ND \\
\hline & & CNMW03-W-22513 & $9 / 26 / 06$ & 2.7 & ND & ND \\
\hline & & CNMW03-W-15494 & $3 / 27 / 07$ & 2.5 & ND & ND \\
\hline & & CNMW03-W-16223 & $9 / 25 / 07$ & 3.5 & ND & ND \\
\hline & & CNMW03-W-26001 & $3 / 12 / 08$ & 2.3 & ND & ND \\
\hline & & CNMW03-W-26675 & $9 / 9 / 08$ & 3.2 & $0.3 \mathrm{~J}$ & ND \\
\hline & & CNMW03-W-27151 & 10/6/09 & 6.2 & ND & ND \\
\hline \multirow[t]{10}{*}{ MW04 } & $37.5-47.5$ & CNMW04-W-16180 & $8 / 24 / 04$ & ND & ND & ND \\
\hline & & CNMW04-W-19280 & 9/11/05 & $0.9 \mathrm{~J}$ & ND & ND \\
\hline & & CNMW04-W-16311 & $10 / 11 / 05$ & $0.8 \mathrm{~J}$ & ND & ND \\
\hline & & CNMW04-W-19891 & $3 / 15 / 06$ & 1.3 & ND & ND \\
\hline & & CNMW04-W-22506 & $9 / 25 / 06$ & 1.4 & $0.1 \mathrm{~J}$ & ND \\
\hline & & CNMW04-W-16210 & $3 / 28 / 07$ & 2.1 & ND & ND \\
\hline & & CNMW04-W-16220 & $9 / 24 / 07$ & 2.0 & ND & ND \\
\hline & & CNMW04-W-26024 & $3 / 19 / 08$ & 1.3 & ND & ND \\
\hline & & CNMW04-W-26676 & 9/9/08 & 2.0 & ND & ND \\
\hline & & CNMW04-W-27152 & 10/7/09 & 2.9 & ND & ND \\
\hline \multirow[t]{10}{*}{ MW05 } & $34.5-44.5$ & CNMW05-W-16183 & $8 / 25 / 04$ & ND & ND & ND \\
\hline & & CNMW05-W-19279 & 9/10/05 & 1.9 & ND & ND \\
\hline & & CNMW05-W-16312 & $10 / 11 / 05$ & 1.5 & ND & ND \\
\hline & & CNMW05-W-19976 & $3 / 15 / 06$ & 1.3 & ND & ND \\
\hline & & CNMW05-W-22505 & $9 / 25 / 06$ & 1.3 & ND & ND \\
\hline & & CNMW05-W-16213 & $3 / 28 / 07$ & $0.5 \mathrm{~J}$ & ND & ND \\
\hline & & CNMW05-W-16218 & $9 / 24 / 07$ & 1.2 & ND & ND \\
\hline & & CNMW05-W-26025 & 3/19/08 & 1.9 & ND & ND \\
\hline & & CNMW05-W-26677 & $9 / 10 / 08$ & 13 & $0.7 \mathrm{~J}$ & ND \\
\hline & & CNMW05-W-27153 & 10/7/09 & 18 & 1.1 & ND \\
\hline
\end{tabular}


TABLE 3.2 (Cont.)

\begin{tabular}{|c|c|c|c|c|c|c|}
\hline \multirow[b]{2}{*}{ Well } & \multirow[b]{2}{*}{$\begin{array}{l}\text { Screen } \\
\text { Interval } \\
\text { (ft BGL) }\end{array}$} & \multirow[b]{2}{*}{ Sample } & \multirow[b]{2}{*}{$\begin{array}{l}\text { Sample } \\
\text { Date }\end{array}$} & \multicolumn{3}{|c|}{ Concentration $(\mu \mathrm{g} / \mathrm{L})$} \\
\hline & & & & $\begin{array}{c}\text { Carbon } \\
\text { Tetrachloride }\end{array}$ & Chloroform & $\begin{array}{l}\text { Methylene } \\
\text { Chloride }\end{array}$ \\
\hline \multirow[t]{10}{*}{ MW06 } & $46.5-56.5$ & CNMW06-W-16184 & $8 / 25 / 04$ & ND & ND & ND \\
\hline & & CNMW06-W-19278 & 9/10/05 & ND & ND & ND \\
\hline & & CNMW06-W-16313 & $10 / 11 / 05$ & $0.3 \mathrm{~J}$ & ND & ND \\
\hline & & CNMW06-W-19889 & $3 / 15 / 06$ & $0.2 \mathrm{~J}$ & ND & ND \\
\hline & & CNMW06-W-22511 & $9 / 27 / 06$ & ND & ND & ND \\
\hline & & CNMW06-W-16208 & $3 / 27 / 07$ & ND & ND & ND \\
\hline & & CNMW06-W-16222 & $9 / 24 / 07$ & ND & ND & ND \\
\hline & & CNMW06-W-26026 & 3/19/08 & ND & ND & ND \\
\hline & & CNMW06-W-26678 & $9 / 9 / 08$ & ND & ND & ND \\
\hline & & CNMW06-W-27154 & 10/6/09 & ND & ND & ND \\
\hline \multirow[t]{7}{*}{ MW07 } & $45-55$ & CNMW07-W-19887 & $3 / 14 / 06$ & $0.4 \mathrm{~J}$ & $0.6 \mathrm{~J}$ & ND \\
\hline & & CNMW07-W-22512 & $9 / 26 / 06$ & 1.1 & ND & ND \\
\hline & & CNMW07-W-15492 & $3 / 26 / 07$ & 1.8 & ND & ND \\
\hline & & CNMW07-W-16221 & $9 / 24 / 07$ & 2.4 & ND & ND \\
\hline & & CNMW07-W-26027 & $3 / 19 / 08$ & 3.0 & ND & ND \\
\hline & & CNMW07-W-26679 & 9/9/08 & 4.0 & $0.2 \mathrm{~J}$ & ND \\
\hline & & CNMW07-W-27155 & 10/6/09 & 5.1 & $0.6 \mathrm{~J}$ & ND \\
\hline \multirow[t]{6}{*}{ MW08 } & $38-53$ & CNMW08-W-19284 & $3 / 14 / 06$ & ND & ND & ND \\
\hline & & CNMW08-W-22507 & 9/26/06 & ND & ND & ND \\
\hline & & CNMW08-W-15493 & $3 / 27 / 07$ & ND & ND & ND \\
\hline & & CNMW08-W-16226 & $9 / 25 / 07$ & ND & ND & ND \\
\hline & & CNMW08-W-26028 & $3 / 20 / 08$ & ND & ND & ND \\
\hline & & CNMW08-W-26680 & 9/10/08 & ND & ND & ND \\
\hline \multirow[t]{7}{*}{ MW09 } & $25-35$ & CNMW09-W-19285 & $3 / 15 / 06$ & ND & ND & ND \\
\hline & & CNMW09-W-22504 & $9 / 25 / 06$ & ND & ND & ND \\
\hline & & CNMW09-W-16209 & $3 / 27 / 07$ & ND & ND & ND \\
\hline & & CNMW09-W-16219 & $9 / 24 / 07$ & ND & ND & ND \\
\hline & & CNMW09-W-26029 & $3 / 20 / 08$ & ND & ND & ND \\
\hline & & CNMW09-W-26681 & $9 / 10 / 08$ & ND & ND & ND \\
\hline & & CNMW09-W-27157 & 10/6/09 & ND & ND & ND \\
\hline \multirow[t]{7}{*}{ MW10 } & $30-45$ & CNMW10-W-19886 & $3 / 14 / 06$ & ND & ND & ND \\
\hline & & CNMW10-W-22510 & 9/26/06 & ND & ND & ND \\
\hline & & CNMW10-W-16215 & $3 / 28 / 07$ & ND & ND & ND \\
\hline & & CNMW10-W-16224 & $9 / 25 / 07$ & ND & ND & ND \\
\hline & & CNMW10-W-26030 & $3 / 20 / 08$ & ND & ND & ND \\
\hline & & CNMW10-W-26682 & $9 / 9 / 08$ & ND & ND & ND \\
\hline & & CNMW10-W-27158 & 10/6/09 & ND & ND & ND \\
\hline \multirow[t]{10}{*}{ SB01 } & $40-50$ & CNSB01-W-16188 & $8 / 26 / 04$ & 186 & 6.5 & ND \\
\hline & & CNSB01-W-19274 & $9 / 9 / 05$ & 269 & 6.8 & ND \\
\hline & & CNSB01-W-16314 & $10 / 12 / 05$ & 288 & 6.6 & ND \\
\hline & & CNSB01-W-19979 & $3 / 17 / 06$ & 320 & 5.7 & ND \\
\hline & & CNSB01-W-22516 & $9 / 27 / 06$ & 267 & 6.3 & ND \\
\hline & & CNSB01-W-15491 & $3 / 27 / 07$ & 222 & 4.9 & ND \\
\hline & & CNSB01-W-16232 & $9 / 27 / 07$ & 283 & 4.6 & ND \\
\hline & & CNSB01-W-26031 & $3 / 20 / 08$ & 325 & 4.8 & ND \\
\hline & & CNSB01-W-26683 & 9/10/08 & 378 & 4.1 & ND \\
\hline & & CNSB01-W-27159 & $10 / 7 / 09$ & 396 & 5.0 & ND \\
\hline
\end{tabular}


TABLE 3.2 (Cont.)

\begin{tabular}{|c|c|c|c|c|c|c|}
\hline \multirow[b]{2}{*}{ Well } & \multirow[b]{2}{*}{$\begin{array}{l}\text { Screen } \\
\text { Interval } \\
\text { (ft BGL) }\end{array}$} & \multirow[b]{2}{*}{ Sample } & \multirow[b]{2}{*}{$\begin{array}{l}\text { Sample } \\
\text { Date }\end{array}$} & \multicolumn{3}{|c|}{ Concentration $(\mu \mathrm{g} / \mathrm{L})$} \\
\hline & & & & $\begin{array}{c}\text { Carbon } \\
\text { Tetrachloride }\end{array}$ & Chloroform & $\begin{array}{l}\text { Methylene } \\
\text { Chloride }\end{array}$ \\
\hline \multirow[t]{10}{*}{ SB04 } & $51-61$ & CNSB04-W-16189 & $8 / 26 / 04$ & 30 & ND & ND \\
\hline & & CNSB04-W-19273 & 9/9/05 & 47 & $0.6 \mathrm{~J}$ & ND \\
\hline & & CNSB04-W-16315 & $10 / 12 / 05$ & 44 & $0.5 \mathrm{~J}$ & ND \\
\hline & & CNSB04-W-19906 & 3/16/06 & 51 & $0.5 \mathrm{~J}$ & $0.4 \mathrm{~J} \mathrm{~B}^{f}$ \\
\hline & & CNSB04-W-22503 & 9/25/06 & 54 & $0.7 \mathrm{~J}$ & ND \\
\hline & & CNSB04-W-16216 & $3 / 28 / 07$ & 44 & $0.5 \mathrm{~J}$ & ND \\
\hline & & CNSB04-W-16230 & 9/26/07 & 36 & $0.4 \mathrm{~J}$ & ND \\
\hline & & CNSB04-W-26002 & $3 / 12 / 08$ & 30 & $0.3 \mathrm{~J}$ & ND \\
\hline & & CNSB04-W-26684 & 9/9/08 & 15 & $0.3 \mathrm{~J}$ & ND \\
\hline & & CNSB04-W-27160 & 10/8/09 & 17 & $0.3 \mathrm{~J}$ & ND \\
\hline \multirow[t]{10}{*}{ SB05 } & $32-42$ & CNSB05-W-16190 & $8 / 26 / 04$ & 59 & 5.5 & ND \\
\hline & & CNSB05-W-19275 & $9 / 9 / 05$ & 77 & 7.2 & ND \\
\hline & & CNSB05-W-16323 & $10 / 12 / 05$ & 54 & 5.5 & ND \\
\hline & & CNSB05-W-19904 & 3/17/06 & 104 & 7.2 & ND \\
\hline & & CNSB05-W-19940 & 9/27/06 & 139 & 12 & ND \\
\hline & & CNSB05-W-16212 & $3 / 28 / 07$ & 138 & 12 & ND \\
\hline & & CNSB05-W-16233 & $9 / 26 / 07$ & 221 & 16 & ND \\
\hline & & CNSB05-W-26032 & $3 / 20 / 08$ & 224 & 17 & ND \\
\hline & & CNSB05-W-26685 & 9/9/08 & 256 & 20 & ND \\
\hline & & CNSB05-W-27161 & 10/8/09 & 289 & 19 & ND \\
\hline \multirow[t]{7}{*}{ SB07R } & $45-60$ & CNSB07R-W-19978 & $3 / 15 / 06$ & 41 & 2.7 & ND \\
\hline & & CNSB07R-W-19924 & 9/26/06 & 30 & 1.7 & ND \\
\hline & & CNSB07R-W-15490 & $3 / 26 / 07$ & 30 & 1.7 & ND \\
\hline & & CNSB07R-W-16225 & $9 / 25 / 07$ & 50 & 2.4 & ND \\
\hline & & CNSB07R-W-26003 & $3 / 12 / 08$ & 13 & $0.9 \mathrm{~J}$ & ND \\
\hline & & CNSB07R-W-26686 & 9/9/08 & 21 & 1.4 & ND \\
\hline & & CNSB07R-W-27162 & 10/7/09 & 38 & 1.7 & ND \\
\hline \multirow[t]{10}{*}{ SB08 } & $52-62$ & CNSB08-W-16192 & $8 / 26 / 04$ & 79 & 3.1 & ND \\
\hline & & CNSB08-W-19272 & $9 / 8 / 05$ & 80 & 2.6 & ND \\
\hline & & CNSB08-W-16317 & $10 / 12 / 05$ & 77 & 2.8 & ND \\
\hline & & CNSB08-W-19903 & 3/17/06 & 91 & 2.7 & ND \\
\hline & & CNSB08-W-22500 & 9/21/06 & 53 & 1.6 & ND \\
\hline & & CNSB08-W-16214 & $3 / 28 / 07$ & 64 & 2.0 & ND \\
\hline & & CNSB08-W-16229 & $9 / 26 / 07$ & 68 & 1.8 & ND \\
\hline & & CNSB08-W-26004 & $3 / 12 / 08$ & 28 & 1.1 & ND \\
\hline & & CNSB08-W-26687 & 9/8/08 & 22 & 1.2 & ND \\
\hline & & CBSB08-W-27163 & 10/8/09 & 29 & 1.2 & ND \\
\hline \multirow[t]{9}{*}{ SB09 } & $32-42$ & CNSB09-W-16193 & $8 / 26 / 04$ & ND & ND & ND \\
\hline & & CNSB09-W-19281 & 9/11/05 & ND & ND & ND \\
\hline & & CNSB09-W-16318 & $10 / 11 / 05$ & ND & ND & ND \\
\hline & & CNSB09-W-19902 & $3 / 17 / 06$ & ND & ND & ND \\
\hline & & CNSB09-W-22502 & 9/25/06 & ND & ND & ND \\
\hline & & CNSB09-W-16211 & $3 / 28 / 07$ & ND & ND & ND \\
\hline & & CNSB09-W-16231 & 9/26/07 & ND & ND & ND \\
\hline & & CNSB09-W-26033 & $3 / 20 / 08$ & ND & ND & ND \\
\hline & & CNSB09-W-26688 & 9/10/08 & ND & ND & ND \\
\hline
\end{tabular}


TABLE 3.2 (Cont.)

\begin{tabular}{|c|c|c|c|c|c|c|}
\hline \multirow[b]{2}{*}{ Well } & \multirow[b]{2}{*}{$\begin{array}{l}\text { Screen } \\
\text { Interval } \\
\text { (ft BGL) }\end{array}$} & \multirow[b]{2}{*}{ Sample } & \multirow[b]{2}{*}{$\begin{array}{l}\text { Sample } \\
\text { Date }\end{array}$} & \multicolumn{3}{|c|}{ Concentration $(\mu \mathrm{g} / \mathrm{L})$} \\
\hline & & & & $\begin{array}{c}\text { Carbon } \\
\text { Tetrachloride }\end{array}$ & Chloroform & $\begin{array}{c}\text { Methylene } \\
\text { Chloride }\end{array}$ \\
\hline
\end{tabular}

a Regulatory levels (KDHE Tier 2 RSBL values):

Compound $\quad$ Concentration $(\mu \mathrm{g} / \mathrm{L})$

$\begin{array}{lc}\text { Carbon tetrachloride } & 5.0 \\ \text { Chloroform } & 80 \\ \text { Methylene chloride } & 5.0\end{array}$

b ND, not detected at an instrument detection limit of $0.1 \mu \mathrm{g} / \mathrm{L}$.

c Qualifier R indicates that the contaminant was present in the associated equipment rinsate.

d Data are for samples collected prior to implementation of the IM ISCR pilot test in November 2007. More recent results are in Table 3.4.

e Qualifier J indicates an estimated concentration below the method quantitation limit of $1.0 \mu \mathrm{g} / \mathrm{L}$.

f Qualifier B indicates that the contaminant was present in the associated method blank. 
TABLE 3.3 Field measurements for groundwater samples collected from the sitewide monitoring points at Centralia, August 2004 to October 2009.

\begin{tabular}{|c|c|c|c|c|c|c|c|c|c|}
\hline \multirow[b]{2}{*}{ Well } & \multirow{2}{*}{$\begin{array}{l}\text { Screen } \\
\text { Interval } \\
\text { (ft BGL) }\end{array}$} & \multirow[b]{2}{*}{$\begin{array}{c}\text { Sample } \\
\text { Date }\end{array}$} & \multirow[b]{2}{*}{$\begin{array}{c}\text { Temperature } \\
\left({ }^{\circ} \mathrm{C}\right)\end{array}$} & \multirow[b]{2}{*}{$\mathrm{pH}$} & \multirow[b]{2}{*}{$\begin{array}{c}\text { Conductivity } \\
(\mu \mathrm{S} / \mathrm{cm})\end{array}$} & \multicolumn{3}{|c|}{ Concentration (mg/L) } & \multirow[b]{2}{*}{$\begin{array}{l}\text { ORP } \\
(\mathrm{mV})\end{array}$} \\
\hline & & & & & & $\begin{array}{l}\text { Dissolved } \\
\text { Oxygen }\end{array}$ & $\begin{array}{l}\text { Carbon } \\
\text { Dioxide }\end{array}$ & Iron(II) & \\
\hline \multirow[t]{9}{*}{ MW01 } & $54.5-64.5$ & $8 / 24 / 04$ & 16.3 & 7.39 & 652 & 0.06 & 25 & 0.00 & 230 \\
\hline & & 9/10/05 & 16.3 & 7.26 & 599 & 6.31 & $-^{a}$ & 0.00 & 104 \\
\hline & & $10 / 11 / 05$ & 16.4 & 6.45 & 634 & - & - & - & - \\
\hline & & $3 / 15 / 06$ & 14.3 & 7.56 & 621 & 9.33 & 30 & 0.04 & 297 \\
\hline & & 9/25/06 & 13.3 & 7.01 & 782 & 6.82 & 50 & 0.31 & 92 \\
\hline & & $3 / 29 / 07$ & 16.5 & 6.54 & 629 & 4.39 & - & 0.00 & 174 \\
\hline & & 9/26/07 & 17.8 & 7.06 & 630 & 0.89 & 35 & 0.09 & 146 \\
\hline & & $3 / 19 / 08$ & 9.5 & 7.31 & 613 & 3.34 & - & - & 122 \\
\hline & & $9 / 9 / 08$ & 13.9 & 7.28 & 595 & 5.18 & 20 & 0.03 & $\begin{array}{r}126 \\
28\end{array}$ \\
\hline \multirow[t]{7}{*}{$\mathrm{MWO}^{\mathrm{b}}$} & $49.5-59.5$ & 8/26/04 & 14.4 & 7.31 & 729 & 0.16 & 20 & 0.12 & 235 \\
\hline & & 9/11/05 & 15.3 & 7.02 & 739 & 1.28 & - & - & - \\
\hline & & $10 / 12 / 05$ & 14.8 & 6.60 & 766 & - & - & - & - \\
\hline & & $3 / 16 / 06$ & 14.2 & 6.78 & 759 & 1.24 & - & 0.00 & 295 \\
\hline & & 9/26/06 & 13.2 & 6.98 & 957 & 3.05 & 40 & 0.06 & 67 \\
\hline & & $3 / 26 / 07$ & 15.7 & 6.39 & 739 & 2.29 & 50 & - & 67 \\
\hline & & $9 / 26 / 07$ & 15.4 & 7.04 & 763 & 3.39 & 25 & 0.00 & 156 \\
\hline \multirow[t]{10}{*}{ MW03 } & $50.5-60.5$ & 8/24/04 & 13.1 & 7.28 & 783 & 0.10 & 55 & 0.21 & 230 \\
\hline & & 9/10/05 & 15.1 & 7.05 & 715 & 10.42 & 65 & 0.00 & 142 \\
\hline & & $10 / 11 / 05$ & 16.3 & 6.46 & 765 & - & - & - & - \\
\hline & & $3 / 17 / 06$ & 13.8 & 6.75 & 753 & 9.39 & 77 & 0.00 & 290 \\
\hline & & $9 / 26 / 06$ & 13.2 & 6.92 & 960 & 11.57 & 45 & 0.08 & 251 \\
\hline & & $3 / 27 / 07$ & 15.3 & 6.40 & 774 & 7.73 & 25 & - & 268 \\
\hline & & $9 / 25 / 07$ & 14.3 & 6.97 & 738 & 8.44 & 30 & 0.00 & 162 \\
\hline & & $3 / 12 / 08$ & 14.6 & 7.12 & 777 & 7.90 & - & 3.13 & 88 \\
\hline & & 9/9/08 & 14.9 & 7.13 & 763 & 9.60 & 110 & 0.12 & 66 \\
\hline & & 10/6/09 & 13.8 & 7.08 & 770 & 9.66 & 95 & 0.03 & 216 \\
\hline \multirow[t]{10}{*}{ MW04 } & $37.5-47.5$ & $8 / 24 / 04$ & 16.2 & 7.39 & 717 & 0.11 & 40 & 0.04 & 210 \\
\hline & & 9/11/05 & 15.4 & 7.18 & 665 & 8.43 & 60 & 0.00 & 226 \\
\hline & & $10 / 11 / 05$ & 14.4 & 7.14 & 811 & - & - & - & - \\
\hline & & $3 / 15 / 06$ & 13.5 & 7.78 & 675 & 6.82 & 55 & 0.06 & 283 \\
\hline & & $9 / 25 / 06$ & - & 7.02 & 613 & 9.13 & 40 & 0.19 & 46 \\
\hline & & $3 / 28 / 07$ & 15.4 & 6.47 & 678 & 5.46 & - & 0.00 & 197 \\
\hline & & 9/24/07 & 17.4 & 7.10 & 667 & 6.94 & 35 & 0.24 & 261 \\
\hline & & $3 / 19 / 08$ & 11.2 & 7.32 & 636 & 7.55 & - & - & 164 \\
\hline & & $9 / 9 / 08$ & 14.2 & 7.14 & 648 & 8.68 & 100 & 0.00 & 72 \\
\hline & & 10/7/09 & 13.9 & 7.17 & 671 & 8.64 & 100 & 0.02 & 183 \\
\hline \multirow[t]{10}{*}{ MW05 } & $34.5-44.5$ & 8/25/04 & 14.3 & 7.14 & 613 & 0.08 & 25 & 0.06 & 215 \\
\hline & & 9/10/05 & 14.2 & 6.80 & 620 & 1.40 & 110 & 0.00 & 160 \\
\hline & & $10 / 11 / 05$ & 14.8 & 6.35 & 610 & - & - & - & - \\
\hline & & $3 / 15 / 06$ & 14.3 & 6.90 & 701 & 0.90 & 30 & 0.06 & 156 \\
\hline & & $9 / 25 / 06$ & 13.6 & 6.95 & 768 & 0.09 & 50 & 0.02 & 55 \\
\hline & & $3 / 28 / 07$ & 14.4 & 6.44 & 573 & 4.53 & 35 & 0.00 & 295 \\
\hline & & $9 / 24 / 07$ & 15.8 & 7.06 & 368 & 3.09 & 45 & 0.00 & 182 \\
\hline & & $3 / 19 / 08$ & 12.9 & 7.42 & 642 & 5.42 & - & - & 177 \\
\hline & & 9/10/08 & 13.9 & 7.11 & 663 & 7.14 & 95 & 0.00 & 130 \\
\hline & & $10 / 7 / 09$ & 14.2 & 7.11 & 672 & 7.05 & 90 & 0.00 & 194 \\
\hline
\end{tabular}


TABLE 3.3 (Cont.)

\begin{tabular}{|c|c|c|c|c|c|c|c|c|c|}
\hline \multirow[b]{2}{*}{ Well } & \multirow{2}{*}{$\begin{array}{l}\text { Screen } \\
\text { Interval } \\
\text { (ft BGL) }\end{array}$} & \multirow[b]{2}{*}{$\begin{array}{l}\text { Sample } \\
\text { Date }\end{array}$} & \multirow[b]{2}{*}{$\begin{array}{l}\text { Temperature } \\
\left({ }^{\circ} \mathrm{C}\right)\end{array}$} & \multirow[b]{2}{*}{$\mathrm{pH}$} & \multirow[b]{2}{*}{$\begin{array}{l}\text { Conductivity } \\
(\mu \mathrm{S} / \mathrm{cm})\end{array}$} & \multicolumn{3}{|c|}{ Concentration (mg/L) } & \multirow[b]{2}{*}{$\begin{array}{l}\text { ORP } \\
(\mathrm{mV})\end{array}$} \\
\hline & & & & & & $\begin{array}{l}\text { Dissolved } \\
\text { Oxygen }\end{array}$ & $\begin{array}{l}\text { Carbon } \\
\text { Dioxide }\end{array}$ & Iron(II) & \\
\hline \multirow{10}{*}{ MW06 } & $46.5-56.5$ & $8 / 25 / 04$ & 15.9 & 7.50 & 637 & 0.05 & 15 & 0.00 & 215 \\
\hline & & 9/10/05 & 14.6 & 7.23 & 659 & 0.04 & 60 & 0.00 & 41 \\
\hline & & $10 / 11 / 05$ & 15.8 & 6.99 & 638 & - & - & - & - \\
\hline & & $3 / 15 / 06$ & 14.1 & 7.38 & 630 & 9.87 & 35 & 0.02 & 263 \\
\hline & & $9 / 27 / 06$ & 13.1 & 6.16 & 652 & 0.05 & 45 & 1.12 & 63 \\
\hline & & $3 / 27 / 07$ & 19.0 & 6.42 & 466 & 0.11 & 20 & 0.00 & 13 \\
\hline & & $9 / 24 / 07$ & 16.8 & 7.11 & 463 & 8.00 & 25 & 0.41 & 191 \\
\hline & & 3/19/08 & 14.1 & 7.01 & 552 & 7.00 & - & - & 172 \\
\hline & & 9/9/08 & 14.4 & 7.20 & 437 & 0.36 & 105 & 0.07 & -96 \\
\hline & & 10/6/09 & 13.5 & 6.69 & 255 & 0.61 & 110 & 0.06 & -72 \\
\hline \multirow[t]{7}{*}{ MW07 } & $45-55$ & 3/14/06 & 14.7 & 6.61 & 709 & 0.34 & - & 0.03 & 143 \\
\hline & & 9/26/06 & 13.1 & 7.23 & 642 & 2.91 & 50 & 0.00 & - \\
\hline & & $3 / 26 / 07$ & 15.8 & 6.50 & 642 & 1.87 & 30 & 0.00 & 261 \\
\hline & & $9 / 24 / 07$ & 19.0 & 7.18 & 609 & 9.05 & 60 & 0.18 & 190 \\
\hline & & 3/19/08 & 12.5 & 7.29 & 647 & 2.70 & - & - & 215 \\
\hline & & 9/9/08 & 15.6 & 7.10 & 629 & 1.41 & 68 & 0.00 & 16 \\
\hline & & 10/6/09 & 13.9 & 7.19 & 618 & 1.42 & 70 & 0.00 & 53 \\
\hline \multirow[t]{6}{*}{ MW08 } & $38-53$ & 3/14/06 & 13.5 & 6.35 & 854 & 5.32 & - & 0.00 & 145 \\
\hline & & $9 / 26 / 06$ & 13.3 & 6.75 & 1095 & 0.16 & 50 & 0.18 & 37 \\
\hline & & 3/27/07 & 15.8 & 6.31 & 874 & 1.49 & 30 & 0.21 & 237 \\
\hline & & $9 / 25 / 07$ & 15.8 & 6.92 & 627 & 1.42 & 45 & 0.14 & 219 \\
\hline & & $3 / 20 / 08$ & 13.5 & 7.19 & 869 & 2.11 & - & - & 185 \\
\hline & & 9/10/08 & 16.3 & 7.03 & 864 & 1.17 & 100 & 0.03 & 117 \\
\hline \multirow[t]{7}{*}{ MW09 } & $25-35$ & 3/15/06 & 17.7 & 7.33 & 664 & 0.95 & 55 & 0.09 & 214 \\
\hline & & 9/25/06 & 12.8 & 6.87 & 859 & 1.59 & 45 & 0.18 & 90 \\
\hline & & $3 / 27 / 07$ & 14.9 & 6.35 & 689 & 4.10 & 30 & 0.69 & 152 \\
\hline & & 9/24/07 & 16.6 & 6.94 & 1999 & 3.86 & 55 & 0.14 & 186 \\
\hline & & $3 / 20 / 08$ & 13.5 & 7.17 & 720 & 4.70 & - & - & 173 \\
\hline & & 9/10/08 & 14.7 & 7.02 & 706 & 3.68 & 110 & 0.07 & 120 \\
\hline & & 10/6/09 & 13.2 & 7.00 & 715 & 3.73 & 110 & 0.08 & 148 \\
\hline \multirow[t]{7}{*}{ MW10 } & $30-45$ & 3/14/06 & 14.8 & 6.60 & 834 & 6.42 & 65 & 0.00 & 166 \\
\hline & & $9 / 26 / 06$ & 13.6 & 6.87 & 1058 & 6.94 & 50 & 0.50 & 51 \\
\hline & & 3/28/07 & 17.0 & 6.36 & 834 & 5.09 & 35 & 0.00 & 270 \\
\hline & & 9/25/07 & 15.8 & 6.94 & 827 & 6.64 & 35 & 0.21 & 199 \\
\hline & & $3 / 20 / 08$ & 10.9 & 7.18 & 898 & 6.12 & - & - & 187 \\
\hline & & $9 / 9 / 08$ & 14.8 & 7.05 & 879 & 7.18 & 100 & 0.06 & 94 \\
\hline & & 10/6/09 & 13.7 & 7.04 & 883 & 6.67 & 95 & 0.08 & 201 \\
\hline \multirow[t]{10}{*}{ SB01 } & $40-50$ & 8/26/04 & 26.0 & 7.46 & 699 & 5.21 & 30 & 0.00 & 210 \\
\hline & & 9/9/05 & 25.0 & 7.11 & 674 & 6.25 & 95 & 0.00 & 140 \\
\hline & & $10 / 12 / 05$ & 13.8 & 7.23 & 686 & - & - & - & - \\
\hline & & $3 / 17 / 06$ & 12.4 & 7.30 & 692 & 5.98 & 55 & 0.00 & 185 \\
\hline & & 9/27/06 & 14.4 & 7.03 & 832 & 6.54 & 40 & 0.52 & 198 \\
\hline & & $3 / 27 / 07$ & 18.0 & 6.37 & 659 & 3.81 & 25 & 0.23 & 173 \\
\hline & & $9 / 27 / 07$ & 13.5 & 7.24 & 720 & 6.55 & 45 & 1.04 & 143 \\
\hline & & $3 / 20 / 08$ & 15.6 & 7.29 & 783 & 8.02 & - & - & 182 \\
\hline & & 9/10/08 & 16.5 & 7.10 & 676 & 2.89 & 100 & 0.17 & 100 \\
\hline & & 10/7/09 & 14.8 & 7.11 & 761 & 7.69 & 105 & 0.07 & 215 \\
\hline
\end{tabular}


TABLE 3.3 (Cont.)

\begin{tabular}{|c|c|c|c|c|c|c|c|c|c|}
\hline \multirow[b]{2}{*}{ Well } & \multirow{2}{*}{$\begin{array}{l}\text { Screen } \\
\text { Interval } \\
\text { (ft BGL) }\end{array}$} & \multirow[b]{2}{*}{$\begin{array}{l}\text { Sample } \\
\text { Date }\end{array}$} & \multirow[b]{2}{*}{$\begin{array}{c}\text { Temperature } \\
\left({ }^{\circ} \mathrm{C}\right)\end{array}$} & \multirow[b]{2}{*}{$\mathrm{pH}$} & \multirow[b]{2}{*}{$\begin{array}{l}\text { Conductivity } \\
(\mu \mathrm{S} / \mathrm{cm})\end{array}$} & \multicolumn{3}{|c|}{ Concentration (mg/L) } & \multirow[b]{2}{*}{$\begin{array}{l}\text { ORP } \\
(\mathrm{mV})\end{array}$} \\
\hline & & & & & & $\begin{array}{l}\text { Dissolved } \\
\text { Oxygen }\end{array}$ & $\begin{array}{l}\text { Carbon } \\
\text { Dioxide }\end{array}$ & Iron(II) & \\
\hline \multirow[t]{10}{*}{ SB04 } & $51-61$ & $8 / 26 / 04$ & 17.9 & 7.14 & 765 & 3.78 & 55 & 0.37 & 230 \\
\hline & & 9/9/05 & 16.0 & 7.09 & 708 & 8.67 & 100 & - & 206 \\
\hline & & $10 / 12 / 05$ & 13.9 & 7.17 & 813 & - & - & - & - \\
\hline & & $3 / 16 / 06$ & 13.0 & 7.57 & 799 & 5.96 & 30 & - & 276 \\
\hline & & $9 / 25 / 06$ & 14.9 & 7.16 & 791 & 9.32 & 70 & 1.18 & 64 \\
\hline & & $3 / 28 / 07$ & 16.2 & 6.45 & 850 & 6.18 & - & 0.23 & 266 \\
\hline & & 9/26/07 & 19.8 & 7.03 & 760 & 6.61 & 30 & 0.00 & 202 \\
\hline & & 3/12/08 & 15.5 & 7.04 & 819 & 6.16 & - & 0.09 & 154 \\
\hline & & 9/9/08 & 16.5 & 7.11 & 802 & 6.48 & 100 & 0.02 & 70 \\
\hline & & 10/8/09 & 12.2 & 7.11 & 797 & 7.43 & 95 & 0.09 & 238 \\
\hline \multirow[t]{10}{*}{ SB05 } & $32-42$ & 8/26/04 & 15.7 & 7.25 & 761 & - & 25 & 0.06 & 220 \\
\hline & & 9/9/05 & 16.9 & 6.98 & 687 & 7.58 & 100 & - & - \\
\hline & & $10 / 12 / 05$ & 14.0 & 7.00 & 728 & - & - & - & - \\
\hline & & 3/17/06 & 13.3 & 7.67 & 718 & 4.80 & 40 & 0.18 & 253 \\
\hline & & 9/27/06 & 13.7 & 6.58 & 763 & 4.70 & 50 & 0.25 & 78 \\
\hline & & 3/28/07 & 16.7 & 4.03 & 1100 & 2.58 & 35 & 0.07 & 296 \\
\hline & & 9/26/07 & 15.1 & 6.98 & 810 & 4.10 & 30 & 0.50 & 221 \\
\hline & & 3/20/08 & 14.5 & 7.11 & 870 & 5.56 & - & - & 206 \\
\hline & & 9/9/08 & 13.7 & 6.79 & 890 & 7.60 & 90 & 0.09 & 56 \\
\hline & & 10/8/09 & 12.7 & 7.09 & 874 & 6.63 & 100 & 0.08 & 209 \\
\hline \multirow[t]{7}{*}{ SB07R } & $45-60$ & 3/15/06 & 16.8 & 7.24 & 685 & 7.41 & 60 & 0.08 & 83 \\
\hline & & 9/26/06 & 13.2 & 6.89 & 842 & 6.17 & 55 & 0.26 & 67 \\
\hline & & $3 / 26 / 07$ & 19.0 & 6.38 & 668 & 5.08 & 40 & 0.07 & 237 \\
\hline & & $9 / 25 / 07$ & 17.4 & 7.06 & 642 & 6.30 & 35 & 0.11 & 170 \\
\hline & & 3/12/08 & 17.3 & 7.18 & 639 & 5.33 & - & 0.00 & 108 \\
\hline & & 9/9/08 & 14.1 & 7.06 & 631 & 5.08 & 100 & 0.07 & 55 \\
\hline & & 10/7/09 & 13.3 & 7.11 & 629 & 6.67 & 110 & 0.10 & 224 \\
\hline \multirow[t]{10}{*}{ SB08 } & $52-62$ & $8 / 26 / 04$ & 19.5 & 7.31 & 635 & 0.16 & 20 & 0.53 & 235 \\
\hline & & 9/8/05 & 21.2 & 7.27 & 598 & 3.21 & 75 & 0.00 & 111 \\
\hline & & $10 / 12 / 05$ & 13.9 & 7.15 & 630 & - & - & - & - \\
\hline & & 3/17/06 & 12.9 & 7.14 & 645 & 3.40 & 40 & 0.00 & 246 \\
\hline & & 9/21/06 & 14.1 & 6.96 & 809 & 4.53 & 40 & 0.00 & 37 \\
\hline & & $3 / 28 / 07$ & 15.8 & 6.53 & 645 & 3.57 & 35 & 0.24 & 208 \\
\hline & & 9/26/07 & 17.4 & 7.11 & 617 & 4.56 & 40 & 0.77 & 156 \\
\hline & & 3/12/08 & 17.1 & 7.17 & 642 & 3.63 & - & 0.14 & 102 \\
\hline & & $9 / 8 / 08$ & 13.6 & 7.14 & 626 & 2.70 & 90 & 0.00 & 230 \\
\hline & & 10/8/09 & 12.3 & 7.22 & 617 & 4.43 & 95 & 0.00 & 221 \\
\hline \multirow[t]{9}{*}{ SB09 } & $32-42$ & 8/26/04 & 30.9 & 7.09 & 910 & 0.26 & 75 & 0.00 & 185 \\
\hline & & 9/11/05 & 14.6 & 6.71 & 877 & 0.13 & 225 & 0.00 & - \\
\hline & & $10 / 11 / 05$ & 13.9 & 6.85 & 910 & - & - & - & - \\
\hline & & $3 / 17 / 06$ & 11.7 & 7.03 & 969 & 1.53 & 99 & 0.00 & 206 \\
\hline & & $9 / 25 / 06$ & 14.2 & 7.00 & 976 & 0.29 & 70 & 0.38 & 86 \\
\hline & & $3 / 28 / 07$ & 14.3 & 6.32 & 957 & 0.89 & 40 & 0.09 & 236 \\
\hline & & 9/26/07 & 15.2 & 6.77 & 969 & 1.53 & 45 & 0.12 & 199 \\
\hline & & 3/20/08 & 10.1 & 6.94 & 1000 & 1.57 & - & - & 221 \\
\hline & & 9/10/08 & 18.4 & 6.87 & 977 & 0.56 & 160 & 0.11 & 109 \\
\hline
\end{tabular}


Monitoring at Centralia, Kansas, in 2009

Version 01, 10/18/10

TABLE 3.3 (Cont.)

\begin{tabular}{|c|c|c|c|c|c|c|c|c|c|}
\hline \multirow[b]{2}{*}{ Well } & \multirow[b]{2}{*}{$\begin{array}{l}\text { Screen } \\
\text { Interval } \\
\text { (ft BGL) }\end{array}$} & \multirow[b]{2}{*}{$\begin{array}{l}\text { Sample } \\
\text { Date }\end{array}$} & \multirow[b]{2}{*}{$\begin{array}{c}\text { Temperature } \\
\left({ }^{\circ} \mathrm{C}\right)\end{array}$} & \multirow[b]{2}{*}{$\mathrm{pH}$} & \multirow[b]{2}{*}{$\begin{array}{c}\text { Conductivity } \\
(\mu \mathrm{S} / \mathrm{cm})\end{array}$} & \multicolumn{3}{|c|}{ Concentration (mg/L) } & \multirow[b]{2}{*}{$\begin{array}{l}\text { ORP } \\
(\mathrm{mV})\end{array}$} \\
\hline & & & & & & $\begin{array}{l}\text { Dissolved } \\
\text { Oxygen }\end{array}$ & $\begin{array}{l}\text { Carbon } \\
\text { Dioxide }\end{array}$ & Iron(II) & \\
\hline
\end{tabular}

a No measurement obtained.

b Data are for samples collected prior to implementation of the IM ISCR pilot test in November 2007. 
TABLE 3.4 Analytical results from the AGEM Laboratory for volatile organic compounds in groundwater samples collected from the IM pilot test monitoring points at Centralia, September 2008 to October 2009.

\begin{tabular}{|c|c|c|c|c|c|c|}
\hline \multirow[b]{2}{*}{ Well } & \multirow{2}{*}{$\begin{array}{l}\text { Screen } \\
\text { Interval } \\
\text { (ft BGL) }\end{array}$} & \multirow[b]{2}{*}{ Sample } & \multirow[b]{2}{*}{$\begin{array}{l}\text { Sample } \\
\text { Date }\end{array}$} & \multicolumn{3}{|c|}{ Concentration $(\mu \mathrm{g} / \mathrm{L})$} \\
\hline & & & & $\begin{array}{c}\text { Carbon } \\
\text { Tetrachloride }\end{array}$ & Chloroform & $\begin{array}{c}\text { Methylene } \\
\text { Chloride }\end{array}$ \\
\hline \multirow[t]{3}{*}{$\mathrm{MWO2}^{\mathrm{a}}$} & $49.5-59.5$ & CNMW02-W-26674 & $9 / 8 / 08$ & 18 & 57 & 11 \\
\hline & & CNMW02-W-27140 & $4 / 22 / 09$ & $N D^{b}$ & ND & 1.8 \\
\hline & & CNMW02-W-27150 & $10 / 8 / 09$ & ND & ND & ND \\
\hline \multirow[t]{3}{*}{ PMP1 } & $50-60$ & CNPMP1-W-26689 & 9/9/08 & 136 & 30 & ND \\
\hline & & CNPMP1-W-27141 & $4 / 22 / 09$ & 102 & 21 & ND \\
\hline & & CNPMP1-W-27165 & 10/7/09 & 167 & 20 & ND \\
\hline \multirow[t]{3}{*}{ PMP2 } & $50-60$ & CNPMP2-W-26690 & 9/9/08 & 1,854 & 318 & 5.6 \\
\hline & & CNPMP2-W-27142 & $4 / 22 / 09$ & 1,398 & 299 & $N A^{c}$ \\
\hline & & CNPMP2-W-27166 & 10/7/09 & 1,384 & 272 & 6.6 \\
\hline \multirow[t]{3}{*}{ PMP3 } & $50-60$ & CNPMP3-W-26691 & 9/9/08 & 21 & 57 & 6.2 \\
\hline & & CNPMP3-W-27143 & $4 / 22 / 09$ & 3.2 & 5.8 & ND \\
\hline & & CNPMP3-W-27167 & 10/7/09 & $0.5 \mathrm{Jd}$ & 3.9 & ND \\
\hline \multirow[t]{2}{*}{ PMP4 } & $48.75-58.75$ & CNPMP4-W-26692 & 9/9/08 & 49 & 4.2 & ND \\
\hline & & CNPMP4-W-27168 & 10/6/09 & 39 & 2.9 & ND \\
\hline \multirow[t]{2}{*}{ PMP5 } & $50-60$ & CNPMP5-W-26693 & 9/10/08 & 418 & 46 & 1.6 \\
\hline & & CNPMP5-W-27169 & 10/8/09 & 728 & 43 & 1.2 \\
\hline \multirow[t]{2}{*}{ PMP6 } & $50-60$ & CNPMP6-W-26694 & $9 / 8 / 08$ & 110 & 7.8 & ND \\
\hline & & CNPMP6-W-27170 & $10 / 6 / 09$ & 199 & 12 & ND \\
\hline \multirow[t]{2}{*}{ PMP7 } & $50-60$ & CNPMP7-W-26695 & 9/9/08 & 119 & 13 & ND \\
\hline & & CNPMP7-W-27171 & $10 / 6 / 09$ & 84 & 23 & 1.8 \\
\hline \multirow[t]{3}{*}{ PMP8 } & $50-60$ & CNPMP8-W-26696 & 9/9/08 & 72 & 125 & 3.4 \\
\hline & & CNPMP8-W-27144 & $4 / 22 / 09$ & 3.2 & 5.6 & 1.9 \\
\hline & & CNPMP8-W-27172 & 10/7/09 & 16 & 21 & 1.8 \\
\hline \multirow[t]{2}{*}{ PMP9 } & $50-60$ & CNPMP9-W-26697 & 9/9/08 & 7.6 & $0.4 \mathrm{~J}$ & ND \\
\hline & & CNPMP9-W-27173 & 10/7/09 & 29 & $0.5 \mathrm{~J}$ & ND \\
\hline
\end{tabular}

a Data are for samples collected after implementation of the IM ISCR pilot test in November 2007.

b ND, not detected at an instrument detection limit of $0.1 \mu \mathrm{g} / \mathrm{L}$.

c NA, no analysis.

$\mathrm{d}$ Qualifier $\mathrm{J}$ indicates an estimated concentration below the method quantitation limit of $1.0 \mu \mathrm{g} / \mathrm{L}$. 
TABLE 3.5 Field measurements for groundwater samples collected from the IM pilot test monitoring points at Centralia, September 2008 to October 2009.

\begin{tabular}{|c|c|c|c|c|c|c|c|c|c|}
\hline \multirow[b]{2}{*}{ Well } & \multirow{2}{*}{$\begin{array}{l}\text { Screen } \\
\text { Interval } \\
\text { (ft BGL) }\end{array}$} & \multirow[b]{2}{*}{$\begin{array}{l}\text { Sample } \\
\text { Date }\end{array}$} & \multirow[b]{2}{*}{$\begin{array}{c}\text { Temperature } \\
\left({ }^{\circ} \mathrm{C}\right)\end{array}$} & \multirow[b]{2}{*}{$\mathrm{pH}$} & \multirow[b]{2}{*}{$\begin{array}{l}\text { Conductivity } \\
(\mu \mathrm{S} / \mathrm{cm})\end{array}$} & \multicolumn{3}{|c|}{ Concentration (mg/L) } & \multirow[b]{2}{*}{$\begin{array}{l}\text { ORP } \\
(\mathrm{mV})\end{array}$} \\
\hline & & & & & & $\begin{array}{l}\text { Dissolved } \\
\text { Oxygen }\end{array}$ & $\begin{array}{l}\text { Carbon } \\
\text { Dioxide }\end{array}$ & Iron(II) & \\
\hline \multirow[t]{3}{*}{$\mathrm{MWO} 2^{\mathrm{a}}$} & $49.5-59.5$ & $9 / 8 / 08$ & 13.1 & 6.12 & 6,821 & 0.40 & 50 & $3.30^{\mathrm{b}}$ & -74 \\
\hline & & $4 / 22 / 09$ & 14.8 & 6.71 & 2,943 & 0.60 & 110 & 2.70 & -131 \\
\hline & & $10 / 8 / 09$ & 12.7 & 6.98 & 1,829 & 0.44 & 50 & 3.06 & -138 \\
\hline \multirow[t]{3}{*}{ PMP1 } & $50-60$ & 9/9/08 & 14.4 & 5.54 & 700 & 1.37 & 115 & 0.23 & 40 \\
\hline & & 4/22/09 & 15.1 & 6.97 & 667 & 3.62 & 115 & 0.60 & -79 \\
\hline & & 10/7/09 & 13.8 & 7.30 & 623 & 0.56 & 110 & 0.33 & -34 \\
\hline \multirow[t]{3}{*}{ PMP2 } & $50-60$ & 9/9/08 & 14.4 & 7.09 & 997 & 0.05 & 180 & 1.68 & -41 \\
\hline & & 4/22/09 & 15.0 & 6.91 & 829 & 3.57 & 150 & 1.36 & -101 \\
\hline & & 10/7/09 & 13.9 & 7.65 & 775 & 0.19 & 160 & 1.53 & -89 \\
\hline \multirow[t]{3}{*}{ PMP3 } & $50-60$ & 9/9/08 & 14.5 & 6.98 & 1301 & 0.03 & 150 & $3.30^{\mathrm{b}}$ & -150 \\
\hline & & 4/22/09 & 14.3 & 7.13 & 506 & 2.64 & 130 & 2.51 & -114 \\
\hline & & $10 / 7 / 09$ & 14.0 & 8.06 & 472 & 0.17 & 140 & 0.37 & -129 \\
\hline \multirow[t]{2}{*}{ PMP4 } & $48.75-58.75$ & 9/9/08 & 14.3 & 4.97 & 738 & 4.87 & 100 & 0.49 & 134 \\
\hline & 80.1000 .10 & $10 / 6 / 09$ & 13.2 & 6.46 & 705 & 2.20 & 110 & 0.08 & 43 \\
\hline \multirow[t]{2}{*}{ PMP5 } & $50-60$ & 9/10/08 & 16.9 & 7.20 & 875 & 2.51 & 105 & 0.18 & 117 \\
\hline & & 10/8/09 & 10.7 & 7.10 & 839 & 3.18 & 100 & 0.00 & 43 \\
\hline \multirow[t]{2}{*}{ PMP6 } & $50-60$ & 9/8/08 & 13.2 & 6.87 & 787 & 3.32 & 75 & 0.09 & 173 \\
\hline & & 10/6/09 & 13.5 & 6.80 & 692 & 2.30 & 80 & 0.07 & 159 \\
\hline \multirow[t]{2}{*}{ PMP7 } & $50-60$ & 9/9/08 & 14.2 & 6.30 & 807 & 2.18 & 70 & 0.18 & 15 \\
\hline & & 10/6/09 & 13.4 & 6.74 & 655 & 0.46 & 70 & 0.12 & -13 \\
\hline \multirow[t]{3}{*}{ PMP8 } & $50-60$ & 9/9/08 & 14.4 & 7.05 & 1388 & 0.03 & 60 & 2.72 & -129 \\
\hline & & $4 / 22 / 09$ & 15.2 & 7.30 & 776 & 1.74 & 150 & 2.03 & -139 \\
\hline & & 10/7/09 & 13.9 & 7.69 & 688 & 0.81 & 120 & 0.27 & -155 \\
\hline \multirow[t]{2}{*}{ PMP9 } & $50-60$ & 9/9/08 & 14.0 & 6.36 & 606 & 7.78 & 120 & 0.10 & 45 \\
\hline & & 10/7/09 & 13.7 & 7.50 & 568 & 5.82 & 125 & 0.06 & -1 \\
\hline
\end{tabular}

a Data are for samples collected after implementation of the IM ISCR pilot test in November 2007.

b Maximum reading from instrument. 


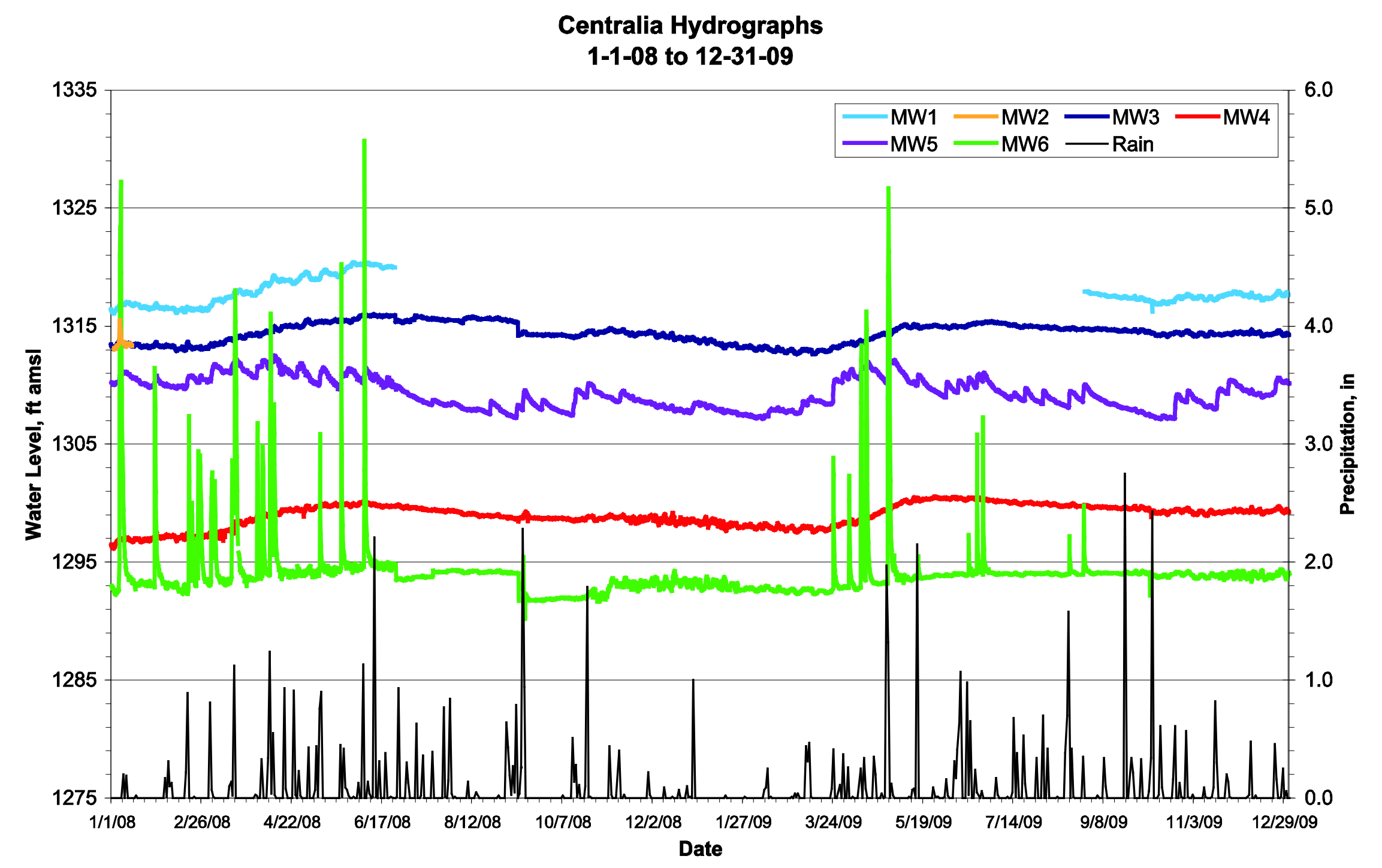

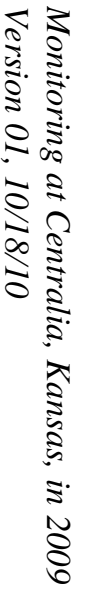

FIGURE 3.1 Hydrographs summarizing results of long-term water level monitoring at Centralia, January 2008 to December 2009. 


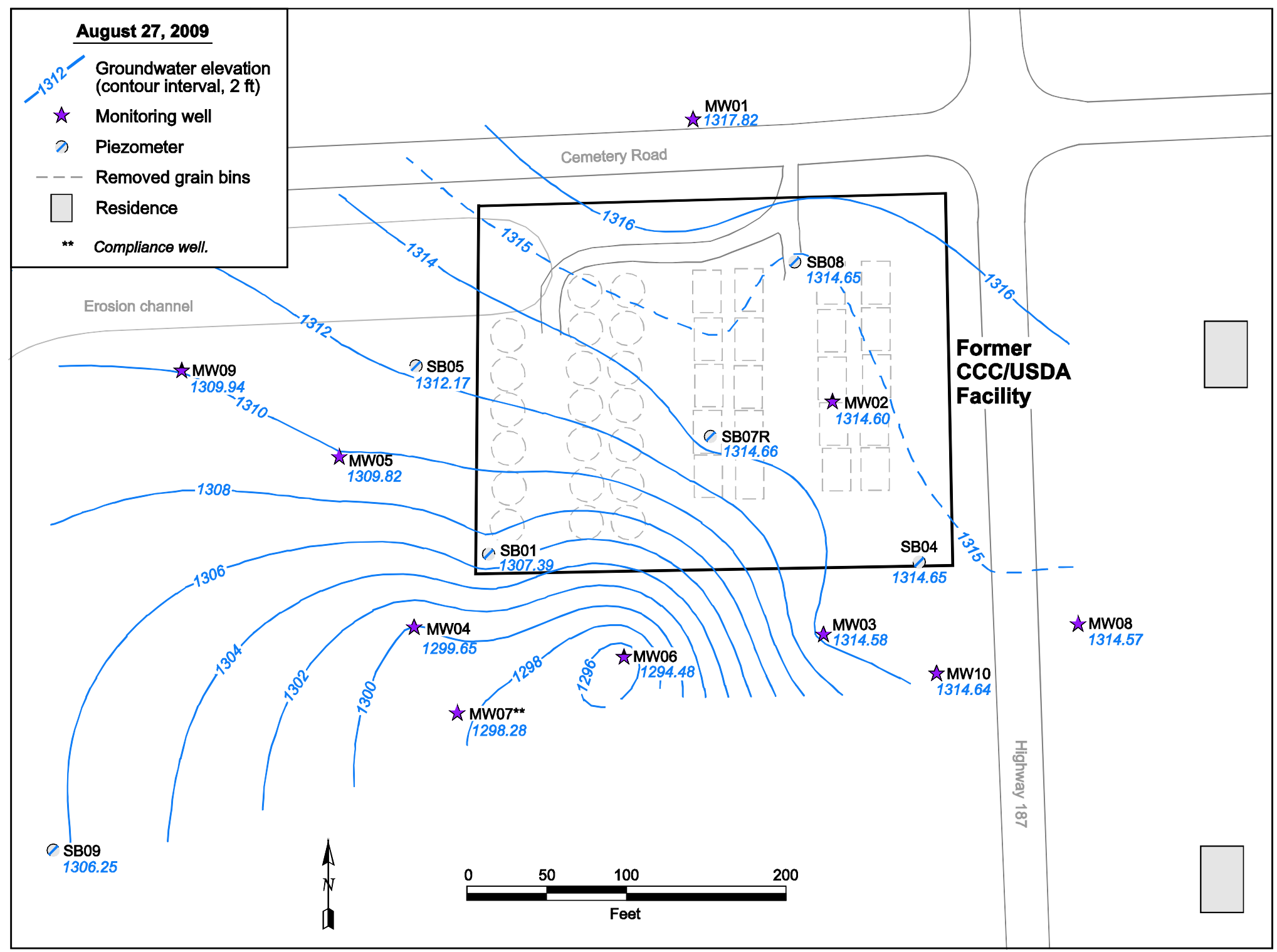

FIGURE 3.2 Potentiometric surface at Centralia, based on water levels measured manually on August 27, 2009. 


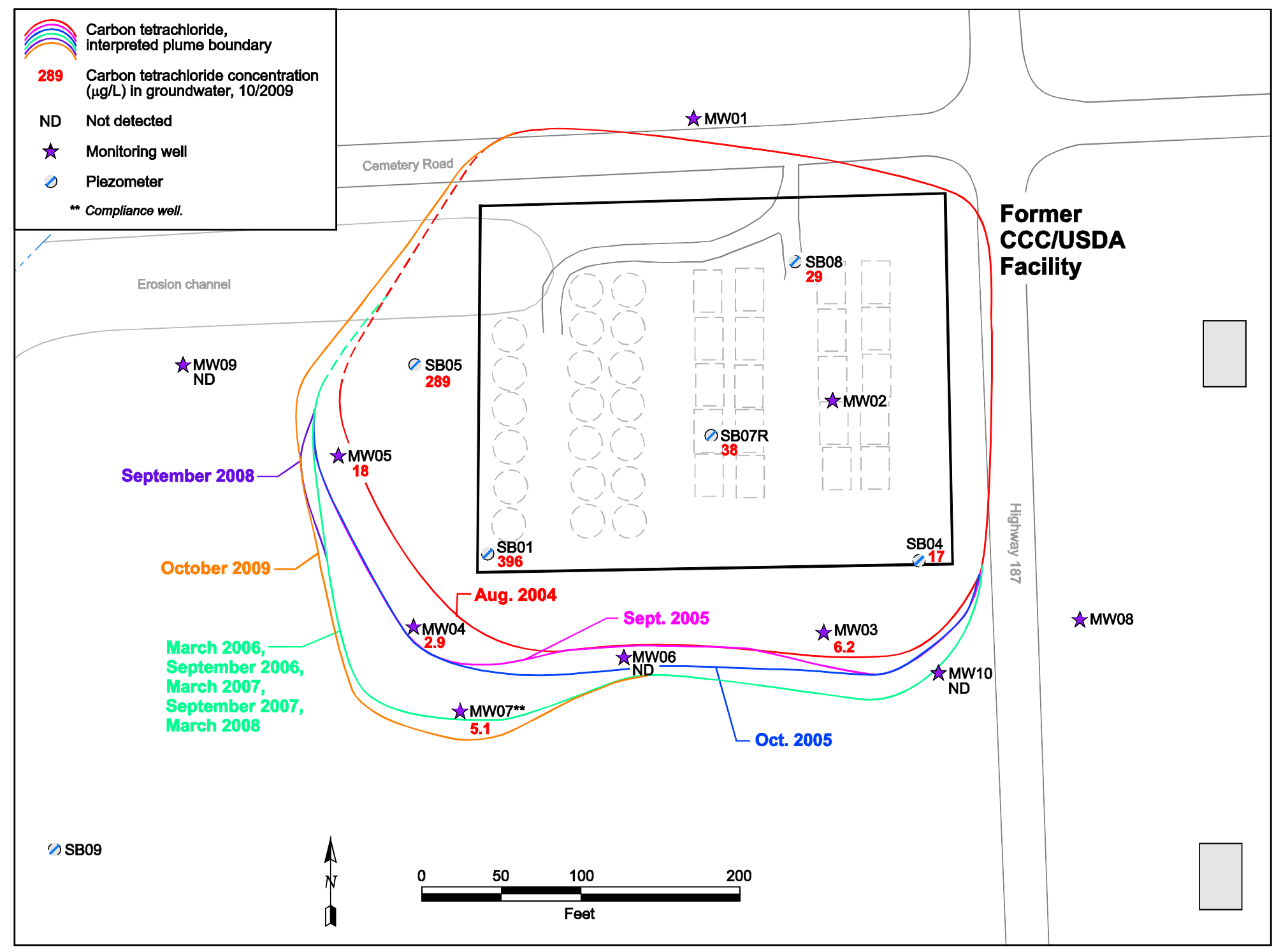

FIGURE 3.3 Carbon tetrachloride levels in groundwater in the KDHE-approved network of sitewide monitoring wells sampled at Centralia in October 2009, with the interpreted lateral extent of the contaminant at intervals during the period August 2004 to

October 2009. 


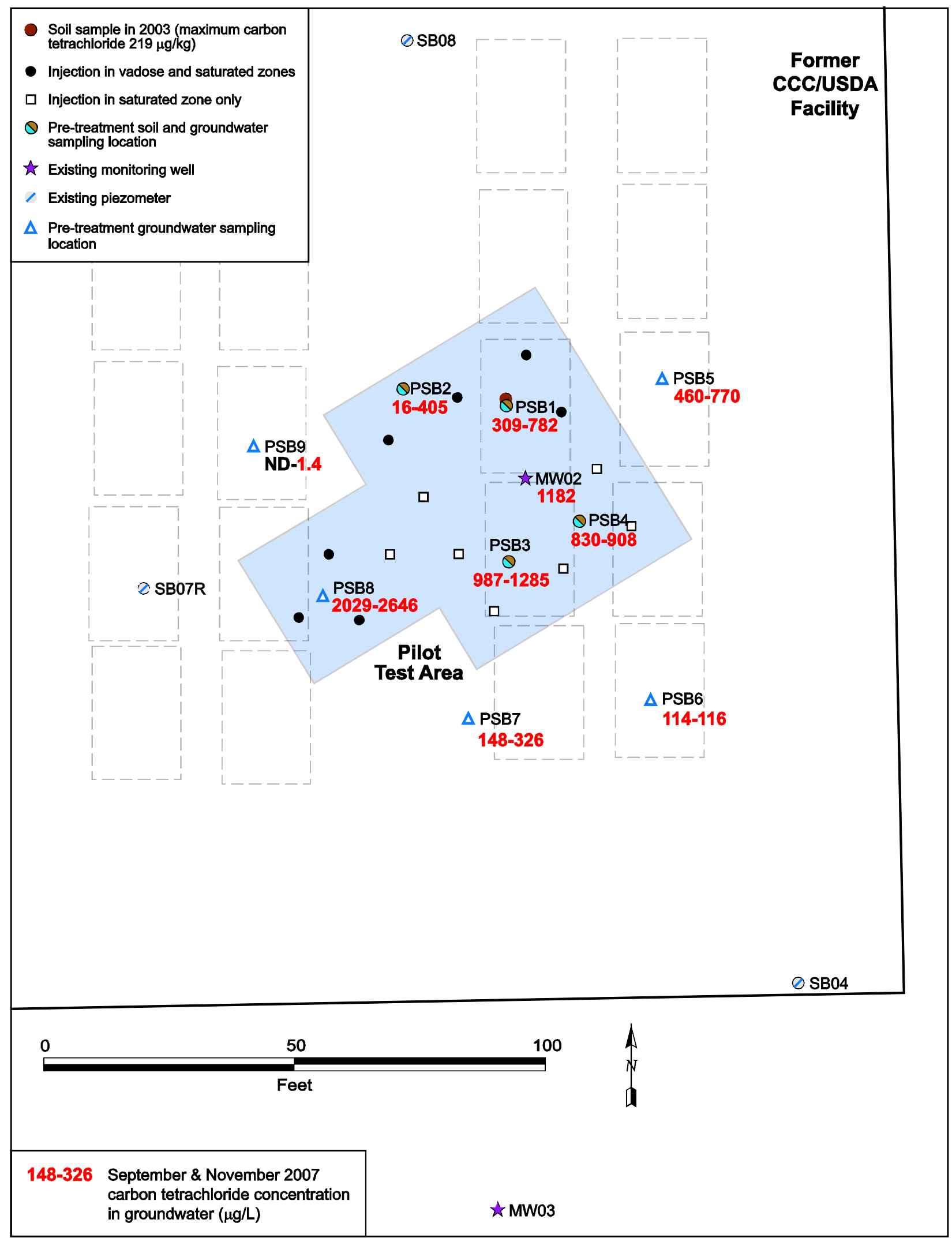

FIGURE 3.4 Carbon tetrachloride in groundwater samples collected during the pre-injection baseline sampling, September and November 2007 


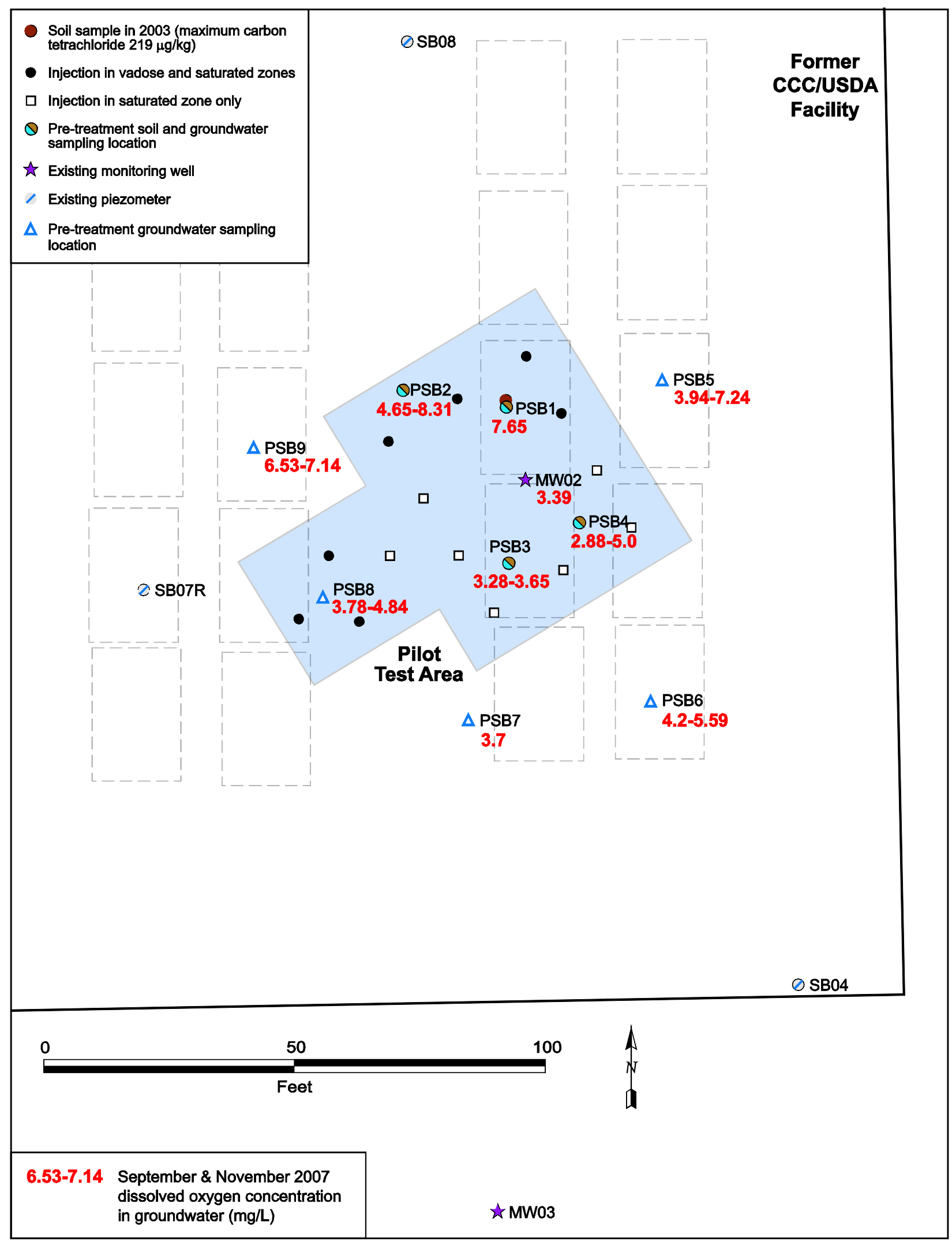

FIGURE 3.5 Field-measured results for DO in groundwater samples collected during the pre-injection baseline sampling, September and November 2007 


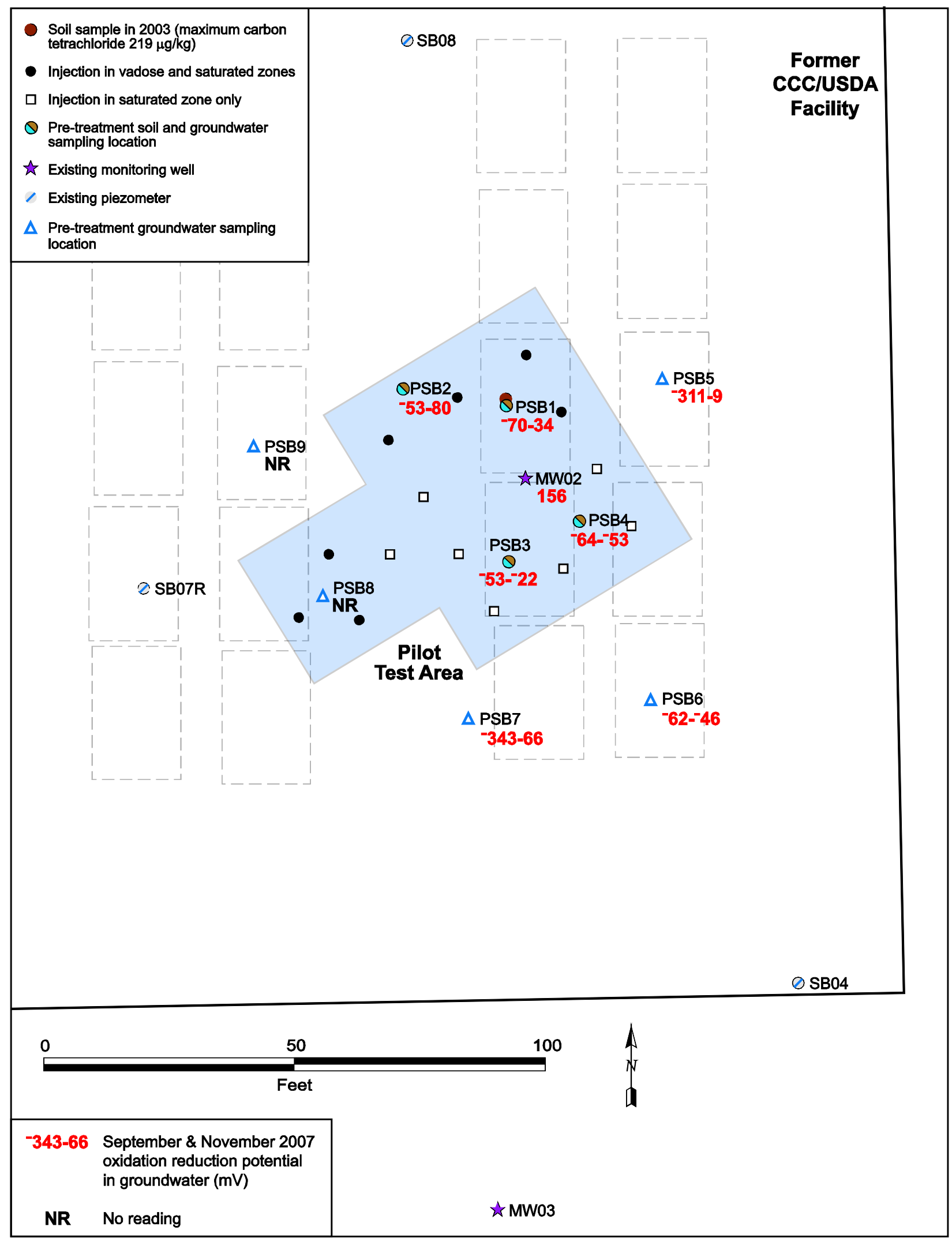

FIGURE 3.6 Field-measured results for ORP in groundwater samples collected during the pre-injection baseline sampling, September and November 2007 


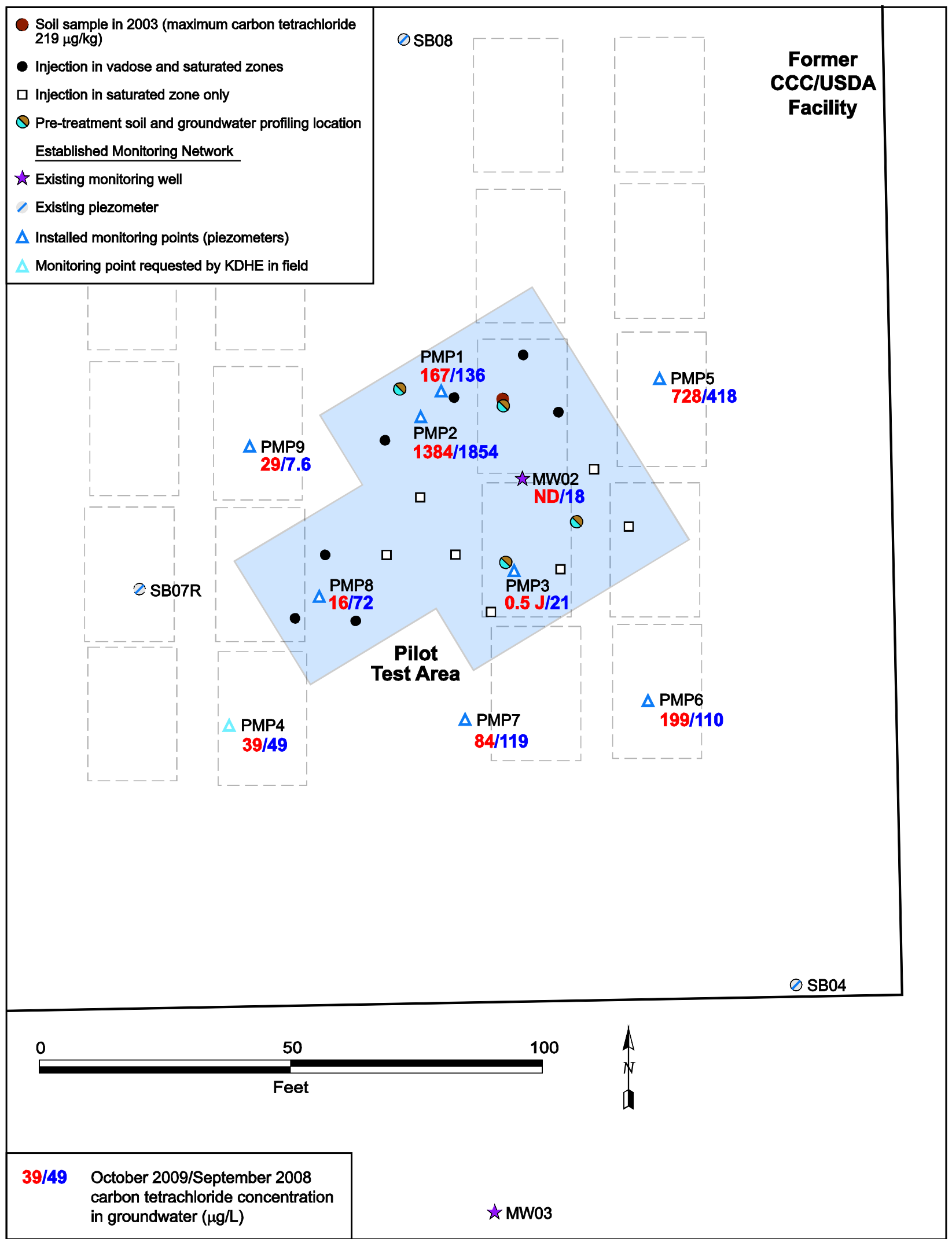

FIGURE 3.7 Analytical results for carbon tetrachloride in groundwater samples collected in October 2009 and September 2008 at the IM pilot test monitoring points. 


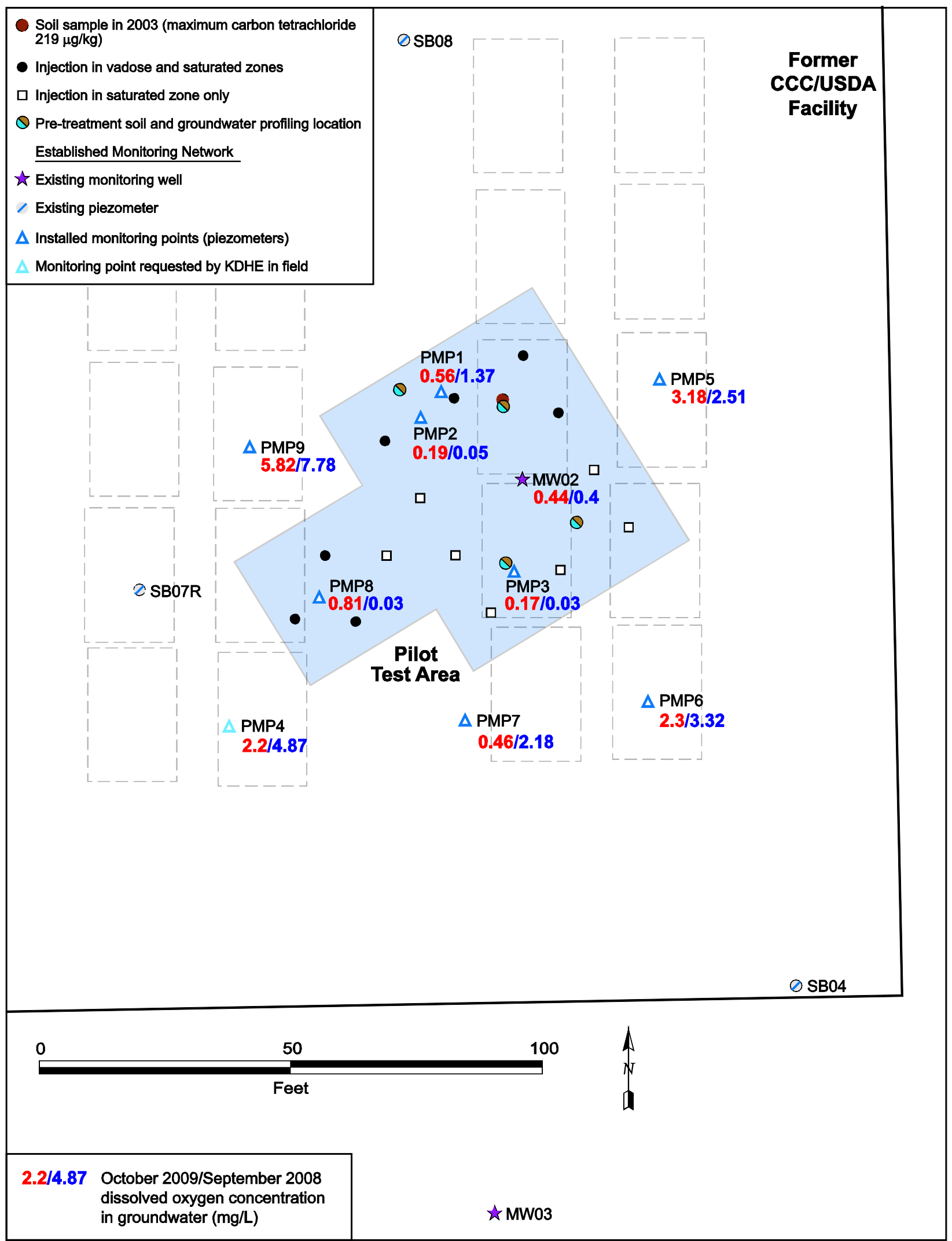

FIGURE 3.8 Field-measured results for DO in groundwater samples collected in October 2009 and September 2008 at the IM pilot test monitoring points. 


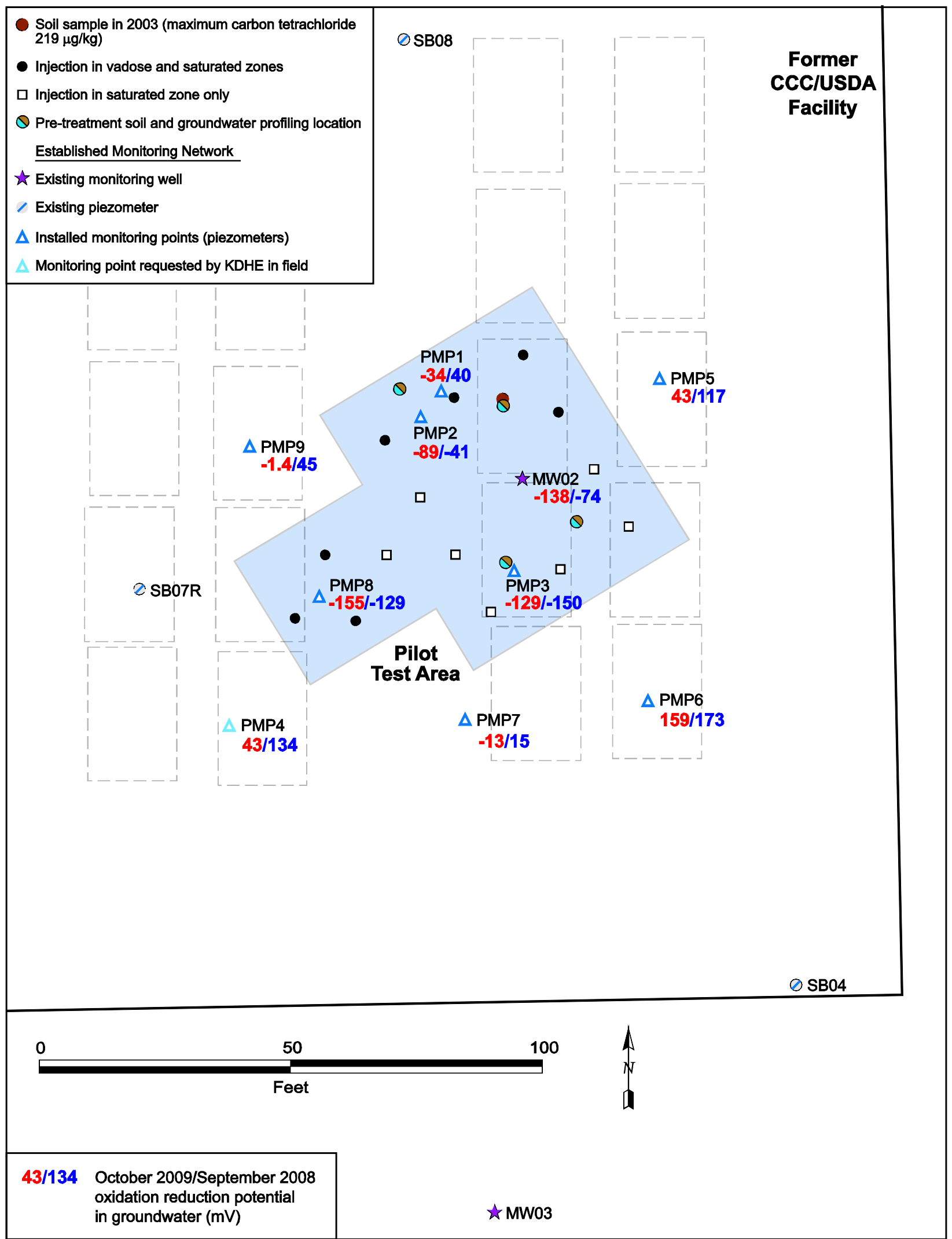

FIGURE 3.9 Field-measured results for ORP in groundwater samples collected in October 2009 and September 2008 at the IM pilot test monitoring points. 


\section{Conclusions and Recommendations}

\subsection{Conclusions}

The findings of the April 2009 and October 2009 monitoring events at Centralia support the following conclusions:

- Measurements of groundwater levels obtained manually and through the use of automatic recorders have consistently indicated an apparent direction of groundwater flow to the south-southwest across the former CCC/USDA facility.

- The October 2009 carbon tetrachloride data for monitoring points in the approved sitewide network were generally consistent with previous results, although a slight increase relative to the concentrations identified in September 2008 was observed at most locations. Longer-term trends of slightly increasing carbon tetrachloride concentrations continue to be observed at monitoring points SB05, MW03, MW04, and MW07, along the western and southern margins of the contaminant distribution in groundwater. These trends suggest very slow expansion of the plume at the downgradient locations.

- Trace to low levels of chloroform identified at sitewide monitoring points MW05, MW07, SB01, SB04, SB05, SB07R, and SB08 suggest that limited natural degradation of carbon tetrachloride is occurring at these locations. The relatively high DO concentrations and positive ORP levels identified at these and most of the other sitewide monitoring points indicate, however, that anaerobic reducing conditions conducive to the reductive dechlorination of carbon tetrachloride are not widely developed, sitewide, within the Centralia aquifer.

- The results of sampling in April and October 2009 indicate that (with one exception, at PMP1) the concentrations of carbon tetrachloride identified in groundwater within the IM pilot test injection field continued to decrease during the present review period. The results also confirmed that oxygen- 
depleted, chemically reducing conditions persist in the injection field as a result of the ISCR injections in November-December 2007.

- From September 2008 to October 2009, DO and ORP values decreased at pilot test monitoring points PMP4, PMP6, PMP7, and PMP9. Carbon tetrachloride concentrations also decreased at PMP4 and PMP7. Monitoring points PMP4, PMP7, and PMP9 lie immediately to the southwest and downgradient of the pilot test injection field, and PMP6 lies near the southern margin of the injection field. These relationships qualitatively suggest that the range of influence of the injected ISCR treatment technology might be increasing slowly with time, as a consequence of natural groundwater flow. Additional monitoring in the pilot test area will be required, however, to confirm these observations.

\subsection{Recommendations}

The groundwater sampling conducted at Centralia in April and October 2009 represented the first monitoring events performed under the interim site monitoring plan (Section 4.2 in Argonne 2009b) approved by the KDHE (2009). The results of these sampling activities continue to support the interpretation that the movement of groundwater and contaminant migration at Centralia are occurring very slowly, in a predictable manner. These findings demonstrate that the KDHE-approved frequency for monitoring of the groundwater at Centralia is sufficient to remain protective of human health and the environment.

In keeping with the approved interim monitoring program, the following sampling events at Centralia are scheduled for 2010:

- April 2010 - Sampling at IM pilot test monitoring points PMP1-PMP3, PMP8, and MW02 (Figure 1.4) inside the injection area.

- September 2010 - Sampling at sitewide monitoring points MW03-MW07, MW09, MW10, SB01, SB04, SB05, SB07R, and SB08 (Figure 1.3), as well as at IM pilot test monitoring points PMP1-PMP9 and MW02 (Figure 1.4). 


\section{References}

Argonne, 2002, Final Master Work Plan: Environmental Investigations at Former CCC/USDA Facilities in Kansas, 2002 Revision, ANL/ER/TR-02/004, prepared for the Commodity Credit Corporation, U.S. Department of Agriculture, Washington, D.C., by Argonne National Laboratory, Argonne, Illinois, December.

Argonne, 2003, Final Phase I Report and Phase II Work Plan: QuickSite ${ }^{\circledR}$ Investigation, Centralia, Kansas, ANL/ER/TR-02/009, prepared for the Commodity Credit Corporation, U.S. Department of Agriculture, Washington, D.C., by Argonne National Laboratory, Argonne, Illinois, March.

Argonne, 2004, Final Phase II Report: QuickSite ${ }^{\circledR}$ Investigation, Centralia, Kansas, ANL/ER/TR-03/006, prepared for the Commodity Credit Corporation, U.S. Department of Agriculture, Washington, D.C., by Argonne National Laboratory, Argonne, Illinois, March.

Argonne, 2005a, Final Report: 2004 Monitoring Well Installation and Sampling at Centralia, Kansas, ANL/ER/TR-04/011, prepared for the Commodity Credit Corporation, U.S. Department of Agriculture, Washington, D.C., by Argonne National Laboratory, Argonne, Illinois, October.

Argonne, 2005b, Final Work Plan: Groundwater Monitoring at Centralia, Kansas, ANL/ER/TR-05/004, prepared for the Commodity Credit Corporation, U.S. Department of Agriculture, Washington, D.C., by Argonne National Laboratory, Argonne, Illinois, August.

Argonne, 2006, Final Report: Groundwater Monitoring at Centralia, Kansas, in SeptemberOctober 2005 and March 2006, with Expansion of the Monitoring Network in January 2006, ANL/EVS/AGEM/TR-06-06, prepared for the Commodity Credit Corporation, U.S. Department of Agriculture, Washington, D.C., by Argonne National Laboratory, Argonne, Illinois, October.

Argonne, 2007a, March 2007 Monitoring Results for Centralia, Kansas, ANL/EVS/AGEM/TR07-08, prepared for the Commodity Credit Corporation, U.S. Department of Agriculture, Washington, D.C., by Argonne National Laboratory, Argonne, Illinois, June.

Argonne, 2007b, Interim Measure Conceptual Design for Remediation at the Former CCC/USDA Grain Storage Facility at Centralia, Kansas: Pilot Test and Remedy 
Implementation, ANL/EVS/AGEM/TR-07-11, prepared for the Commodity Credit Corporation, U.S. Department of Agriculture, Washington, D.C., by Argonne National Laboratory, Argonne, Illinois, October.

Argonne, 2008a, September 2007 Monitoring Results for Centralia, Kansas, ANL/EVS/AGEM/TR-08-01, prepared for the Commodity Credit Corporation, U.S. Department of Agriculture, Washington, D.C., by Argonne National Laboratory, Argonne, Illinois, January.

Argonne, 2008b, March 2008 Monitoring Results for Centralia, Kansas, ANL/EVS/AGEM/TR08-08, prepared for the Commodity Credit Corporation, U.S. Department of Agriculture, Washington, D.C., by Argonne National Laboratory, Argonne, Illinois, May.

Argonne, 2009a, Progress Report and Technical Evaluation of the ISCR Pilot Test Conducted at the Former CCC/USDA Grain Storage Facility in Centralia, Kansas, ANL/EVS/AGEM/TR-0818, prepared for the Commodity Credit Corporation, U.S. Department of Agriculture, Washington, D.C., by Argonne National Laboratory, Argonne, Illinois, January.

Argonne, 2009b, September 2008 Monitoring Results for Centralia, Kansas, ANL/EVS/AGEM/TR-09-01, prepared for the Commodity Credit Corporation, U.S. Department of Agriculture, Washington, D.C., by Argonne National Laboratory, Argonne, Illinois, February.

EPA, 1995, Method 524.2: Measurement of Purgeable Organic Compounds in Water by Capillary Column Gas Chromatography/Mass Spectrometry, Revision 4.1, edited by J.W. Munch, National Exposure Research Laboratory, Office of Research and Development, U.S. Environmental Protection Agency, Cincinnati, Ohio.

EPA, 1998, Technical Protocol for Evaluating Natural Attenuation of Chlorinated Solvents in Ground Water, EPA/600/R-98/128, Office of Research and Development, U.S. Environmental Protection Agency, Washington, D.C., September (http://www.epa.gov/superfund/resources/ gwdocs/protocol.htm).

KDHE, 2001, Monitored Natural Attenuation, Policy BER-RS-042, Bureau of Environmental Remediation, Kansas Department of Health and Environment, Topeka, Kansas, March 30 (revised December 18, 2005; http://www.kdheks.gov/ber/policies/BER_RS_042.pdf). 
KDHE, 2005a, letter from C. Carey (Bureau of Environmental Remediation, Kansas Department of Health and Environment, Topeka, Kansas) to C. Roe (Commodity Credit Corporation, U.S. Department of Agriculture, Washington, D.C.), regarding Draft Report: 2004 Monitoring Well Installation and Sampling, Centralia, Kansas, October 13.

KDHE, 2005b, letter from C. Carey (Bureau of Environmental Remediation, Kansas Department of Health and Environment, Topeka, Kansas) to C. Roe (Commodity Credit Corporation, U.S. Department of Agriculture, Washington, D.C.), regarding Final Work Plan: Groundwater Monitoring at Centralia, Kansas, October 13.

KDHE, 2007, letter from C. Carey (Bureau of Environmental Remediation, Kansas Department of Health and Environment, Topeka, Kansas) to C. Roe (Commodity Credit Corporation, U.S. Department of Agriculture, Washington, D.C.), regarding review of Interim Measure Conceptual Design for Centralia, Kansas, November 9.

KDHE, 2008a, letter from C. Carey (Bureau of Environmental Remediation, Kansas Department of Health and Environment, Topeka, Kansas) to C. Roe (Commodity Credit Corporation, U.S. Department of Agriculture, Washington, D.C.), regarding September 2007 Monitoring Results for Centralia, Kansas, March 12.

KDHE, 2008b, electronic mail message from C. Carey (Bureau of Environmental Remediation, Kansas Department of Health and Environment, Topeka, Kansas) to L. LaFreniere (Argonne National Laboratory, Argonne, Illinois), regarding use of the low-flow sampling technique at Centralia, February 11.

KDHE, 2009, letter from E. Finzer (Bureau of Environmental Remediation, Kansas Department of Health and Environment, Topeka, Kansas) to C. Roe (Commodity Credit Corporation, U.S. Department of Agriculture, Washington, D.C.), regarding Centralia monitoring reports for 2008 and the progress report for the ISCR pilot test, April 6.

Puls, R.W., and M.J. Barcelona, 1996, "Low-Flow (Minimal Drawdown) Ground-Water Sampling Procedures,” EPA/540/S-95/504, in Ground Water Issue, Superfund Technology Support Center for Ground Water, National Risk Management Research Laboratory, Ada, Oklahoma, April (www.epa.gov/tio/tsp/download/lwflw2a.pdf). 
Appendix A:

Sequence of Sampling Activities in 2009 
TABLE A.1 Sequence of sampling activities at Centralia, April 2009 and October 2009.

\begin{tabular}{|c|c|c|c|c|c|c|c|c|}
\hline Date & Time & Sample & Type $^{a}$ & Location & $\begin{array}{l}\text { Depth } \\
\text { (ft BGL) }\end{array}$ & $\begin{array}{l}\text { Chain of } \\
\text { Custody }\end{array}$ & $\begin{array}{l}\text { Shipping } \\
\text { Date }\end{array}$ & Sample Description \\
\hline \multicolumn{9}{|c|}{ April 2009 sampling event } \\
\hline $4 / 22 / 09$ & $11: 18$ & CNMW02-W-27140 & MW & MW02 & $49.5-59.5$ & 2820 & $4 / 22 / 09$ & $\begin{array}{l}\text { Depth to water }=20.8 \mathrm{ft} \text {. Depth of } 4 \text {-in. well = } \\
59.5 \mathrm{ft} \text {. Sample collected by using low-flow } \\
\text { bladder pump positioned at } 54.5 \mathrm{ft} \text { after purging } \\
\text { of } 7 \mathrm{~L} \text {. }\end{array}$ \\
\hline $4 / 22 / 09$ & $11: 30$ & CNQCIR-W-27147 b & $\mathrm{RI}$ & QC & & 2820 & $4 / 22 / 09$ & $\begin{array}{l}\text { Rinsate of decontaminated pump purge line after } \\
\text { collection of sample CNMW02-W-27140. }\end{array}$ \\
\hline $4 / 22 / 09$ & $12: 20$ & CNPMP2-W-27142 & MW & PMP2 & $50-60$ & 2820 & $4 / 22 / 09$ & $\begin{array}{l}\text { Depth to water }=20 \mathrm{ft} \text {. Depth of } 0.5 \text {-in. well }= \\
60 \mathrm{ft} \text {. Sample collected by using low-flow } \\
\text { bladder pump positioned at } 55 \mathrm{ft} \text { after purging } \\
\text { of } 5.5 \mathrm{~L} \text {. }\end{array}$ \\
\hline $4 / 22 / 09$ & $12: 21$ & CNPMP2DUP-W-27145 & MW & PMP2 & $50-60$ & 2820 & $4 / 22 / 09$ & Replicate of sample CNPMP2-W-27142. \\
\hline $4 / 22 / 09$ & $12: 45$ & CNPMP1-W-27141 & MW & PMP1 & $50-60$ & 2820 & $4 / 22 / 09$ & $\begin{array}{l}\text { Depth to water }=20 \mathrm{ft} \text {. Depth of } 0.5 \text {-in. well }= \\
60 \mathrm{ft} \text {. Sample collected by using low-flow } \\
\text { bladder pump positioned at } 55 \mathrm{ft} \text { after purging } \\
\text { of } 5.8 \mathrm{~L} \text {. }\end{array}$ \\
\hline $4 / 22 / 09$ & 13:15 & CNPMP3-W-27143 & MW & PMP3 & $50-60$ & 2820 & $4 / 22 / 09$ & $\begin{array}{l}\text { Depth to water }=22.4 \mathrm{ft} \text {. Depth of } 0.5 \text {-in. well }= \\
60 \mathrm{ft} . \text { Sample collected by using low-flow } \\
\text { bladder pump positioned at } 55 \mathrm{ft} \text { after purging } \\
\text { of } 5.2 \mathrm{~L} \text {. }\end{array}$ \\
\hline $4 / 22 / 09$ & $13: 16$ & CNPMP3DUP-W-27146 & MW & PMP3 & $50-60$ & 2820 & $4 / 22 / 09$ & Replicate of sample CNPMP3-W-27143. \\
\hline $4 / 22 / 09$ & $13: 38$ & CNPMP8-W-27144 & MW & PMP8 & $50-60$ & 2820 & 4/22/09 & $\begin{array}{l}\text { Depth to water }=19.4 \mathrm{ft} \text {. Depth of } 0.5 \text {-in. well }= \\
60 \mathrm{ft} . \text { Sample collected by using low-flow } \\
\text { bladder pump positioned at } 55 \mathrm{ft} \text { after purging } \\
\text { of } 5.3 \mathrm{~L} \text {. }\end{array}$ \\
\hline $4 / 22 / 09$ & $14: 14$ & CNQCTB-W-27148b & TB & QC & & 2820 & $4 / 22 / 09$ & $\begin{array}{l}\text { Trip blank sent to the AGEM Laboratory for } \\
\text { organic analysis with water samples listed on } \\
\text { chain-of-custody form (COC) } 2820 \text { and to } \\
\text { TestAmerica for verification organic analysis } \\
\text { with samples listed on COC } 2819 \text {. }\end{array}$ \\
\hline \multicolumn{9}{|c|}{ October 2009 sampling event } \\
\hline 10/6/09 & $11: 22$ & CNMW10-W-27158 & MW & MW10 & $30-45$ & 2610 & 10/7/09 & $\begin{array}{l}\text { Depth to water }=20.59 \mathrm{ft} \text {. Depth of } 2 \text {-in. well = } \\
45 \mathrm{ft} \text {. Sample collected by using low-flow } \\
\text { bladder pump positioned at } 37.5 \mathrm{ft} \text { after purging } \\
\text { of } 10.25 \mathrm{~L} \text {. }\end{array}$ \\
\hline
\end{tabular}


TABLE A.1 (Cont.)

\begin{tabular}{|c|c|c|c|c|c|c|c|c|}
\hline Date & Time & Sample & Type $^{a}$ & Location & $\begin{array}{l}\text { Depth } \\
\text { (ft BGL) }\end{array}$ & $\begin{array}{l}\text { Chain of } \\
\text { Custody }\end{array}$ & $\begin{array}{l}\text { Shipping } \\
\text { Date }\end{array}$ & Sample Description \\
\hline \multicolumn{9}{|c|}{ October 2009 sampling event (cont.) } \\
\hline 10/6/09 & 13:01 & CNMW03-W-27151 & MW & MW03 & $50.5-60.5$ & 2610 & 10/7/09 & $\begin{array}{l}\text { Depth to water }=20.43 \mathrm{ft} \text {. Depth of } 4 \text {-in. well }= \\
60.5 \mathrm{ft} \text {. Sample collected by using low-flow } \\
\text { bladder pump positioned at } 55.5 \mathrm{ft} \text { after purging } \\
\text { of } 6.5 \mathrm{~L} \text {. }\end{array}$ \\
\hline 10/6/09 & 13:02 & CNMW03DUP-W-27174 & MW & MW03 & $50.5-60.5$ & 2610 & 10/7/09 & Replicate of sample CNMW3-W-27151. \\
\hline $10 / 6 / 09$ & $14: 38$ & CNMW06-W-27154 & MW & MW06 & $46.5-56.5$ & 2610 & $10 / 7 / 09$ & $\begin{array}{l}\text { Depth to water }=36.23 \mathrm{ft} \text {. Depth of } 4 \text {-in. well = } \\
56.5 \mathrm{ft} \text {. Sample collected by using low-flow } \\
\text { bladder pump positioned at } 51.5 \mathrm{ft} \text { after purging } \\
\text { of } 11 \mathrm{~L} \text {. Goldish-yellow tint. }\end{array}$ \\
\hline 10/6/09 & 16:16 & CNMW07-W-27155 & MW & MW07 & $45-55$ & 2610 & 10/7/09 & $\begin{array}{l}\text { Depth to water = } 27.97 \mathrm{ft} \text {. Depth of } 2 \text {-in. well = } \\
55 \mathrm{ft} \text {. Sample collected by using low-flow } \\
\text { bladder pump positioned at } 50 \mathrm{ft} \text { after purging } \\
\text { of } 9 \mathrm{~L} \text {. }\end{array}$ \\
\hline 10/6/09 & $16: 38$ & CNPMP6-W-27170 & MW & PMP6 & $50-60$ & 2610 & 10/7/09 & $\begin{array}{l}\text { Depth to water }=21.53 \mathrm{ft} \text {. Depth of } 0.5 \text {-in. well }= \\
60 \mathrm{ft} \text {. Sample collected by using Waterra pump } \\
\text { positioned at } 55 \mathrm{ft} \text { after purging of } 7 \mathrm{~L} \text {. Light } \\
\text { brown and silty. }\end{array}$ \\
\hline 10/6/09 & $17: 28$ & CNPMP7-W-27171 & MW & PMP7 & $50-60$ & 2610 & 10/7/09 & $\begin{array}{l}\text { Depth to water }=20.54 \mathrm{ft} \text {. Depth of } 0.5 \text {-in. well }= \\
60 \mathrm{ft} \text {. Sample collected by using Waterra pump } \\
\text { positioned at } 55 \mathrm{ft} \text { after purging of } 6 \mathrm{~L} \text {. Cloudy } \\
\text { to clear. }\end{array}$ \\
\hline 10/6/09 & $18: 16$ & CNPMP4-W-27168 & MW & PMP4 & $48.75-58.75$ & 2610 & 10/7/09 & $\begin{array}{l}\text { Depth to water }=18.59 \mathrm{ft} \text {. Depth of } 0.5 \text {-in. well }= \\
58.75 \mathrm{ft} \text {. Sample collected by using Waterra } \\
\text { pump positioned at } 53.75 \mathrm{ft} \text { after purging of } \\
6.5 \mathrm{~L} \text {. Tannish brown in color. }\end{array}$ \\
\hline 10/6/09 & $18: 20$ & CNMW09-W-27157 & MW & MW09 & $25-35$ & 2610 & 10/7/09 & $\begin{array}{l}\text { Depth to water }=3.92 \mathrm{ft} \text {. Depth of } 2 \text {-in. well }= \\
35 \mathrm{ft} \text {. Sample collected by using low-flow } \\
\text { bladder pump positioned at } 30 \mathrm{ft} \text { after purging } \\
\text { of } 12.25 \mathrm{~L} \text {. }\end{array}$ \\
\hline 10/6/09 & $18: 40$ & CNQCIR-W-27176b & RI & QC & - & 2611 & 10/7/09 & $\begin{array}{l}\text { Rinsate of decontaminated sampling line after } \\
\text { collection of sample CNMW09-W-27157. }\end{array}$ \\
\hline 10/7/09 & $11: 13$ & CNSB07R-W-27162 & СРТ/P & SB07R & $45-60$ & 2611 & 10/7/09 & $\begin{array}{l}\text { Depth to water }=18.43 \mathrm{ft} \text {. Depth of } 2 \text {-in. well = } \\
60 \mathrm{ft} \text {. Sample collected by using low-flow } \\
\text { bladder pump positioned at } 52.5 \mathrm{ft} \text { after purging } \\
\text { of } 6.75 \mathrm{~L} \text {. }\end{array}$ \\
\hline
\end{tabular}


TABLE A.1 (Cont.)

\begin{tabular}{|c|c|c|c|c|c|c|c|c|}
\hline Date & Time & Sample & Type $^{a}$ & Location & $\begin{array}{l}\text { Depth } \\
\text { (ft BGL) }\end{array}$ & $\begin{array}{l}\text { Chain of } \\
\text { Custody }\end{array}$ & $\begin{array}{l}\text { Shipping } \\
\text { Date }\end{array}$ & Sample Description \\
\hline \multicolumn{9}{|c|}{ October 2009 sampling event (cont.) } \\
\hline 10/7/09 & $12: 50$ & CNSB01-W-27159 & $\mathrm{CPT} / \mathrm{P}$ & SB01 & $40-50$ & 2611 & 10/7/09 & $\begin{array}{l}\text { Depth to water }=17.42 \mathrm{ft} \text {. Depth of } 1 \text {-in. well = } \\
50 \mathrm{ft} \text {. Sample collected by using low-flow } \\
\text { bladder pump positioned at } 45 \mathrm{ft} \text { after purging } \\
\text { of } 3 \mathrm{~L} \text {. }\end{array}$ \\
\hline 10/7/09 & $12: 51$ & CNSB01DUP-W-27175 & $\mathrm{CPT} / \mathrm{P}$ & SB01 & $40-50$ & 2611 & 10/7/09 & Replicate of sample CNSB01-W-27159. \\
\hline 10/7/09 & $13: 02$ & CNPMP8-W-27172 & MW & PMP8 & $50-60$ & 2611 & 10/7/09 & $\begin{array}{l}\text { Depth to water }=19.87 \mathrm{ft} \text {. Depth of } 0.5 \text {-in. well }= \\
60 \mathrm{ft} \text {. Sample collected by using Waterra pump } \\
\text { positioned at } 55 \mathrm{ft} \text { after purging of } 7 \mathrm{~L} \text {. }\end{array}$ \\
\hline 10/7/09 & $13: 54$ & CNMW05-W-27153 & MW & MW05 & $34.5-44.5$ & 2611 & 10/7/09 & $\begin{array}{l}\text { Depth to water }=11.98 \mathrm{ft} \text {. Depth of } 4 \text {-in. well = } \\
44.5 \mathrm{ft} \text {. Sample collected by using low-flow } \\
\text { bladder pump positioned at } 39.5 \mathrm{ft} \text { after purging } \\
\text { of } 7 \mathrm{~L} \text {. }\end{array}$ \\
\hline 10/7/09 & $14: 18$ & CNPMP3-W-27167 & MW & PMP3 & $50-60$ & 2611 & 10/7/09 & $\begin{array}{l}\text { Depth to water }=21.15 \mathrm{ft} \text {. Depth of } 0.5 \text {-in. well }= \\
60 \mathrm{ft} \text {. Sample collected by using Waterra pump } \\
\text { positioned at } 55 \mathrm{ft} \text { after purging of } 7 \mathrm{~L} \text {. Grayish } \\
\text { in color. }\end{array}$ \\
\hline 10/7/09 & $14: 48$ & CNMW04-W-27152 & MW & MW04 & $37.5-47.5$ & 2611 & 10/7/09 & $\begin{array}{l}\text { Depth to water }=23.75 \mathrm{ft} \text {. Depth of } 4 \text {-in. well }= \\
47.5 \mathrm{ft} \text {. Sample collected by using low-flow } \\
\text { bladder pump positioned at } 42.5 \mathrm{ft} \text { after purging } \\
\text { of } 6.5 \mathrm{~L} \text {. }\end{array}$ \\
\hline 10/7/09 & $15: 22$ & CNPMP9-W-27173 & MW & PMP9 & $50-60$ & 2611 & 10/7/09 & $\begin{array}{l}\text { Depth to water }=15.83 \mathrm{ft} \text {. Depth of } 0.5 \text {-in. well }= \\
60 \mathrm{ft} \text {. Sample collected by using Waterra pump } \\
\text { positioned at } 55 \mathrm{ft} \text { after purging of } 7 \mathrm{~L} \text {. }\end{array}$ \\
\hline 10/7/09 & 16:04 & CNPMP2-W-27166 & MW & PMP2 & $50-60$ & 2611 & 10/7/09 & $\begin{array}{l}\text { Depth to water }=19.84 \mathrm{ft} \text {. Depth of } 0.5 \text {-in. well = } \\
60 \mathrm{ft} \text {. Sample collected by using Waterra pump } \\
\text { positioned at } 55 \mathrm{ft} \text { after purging of } 7 \mathrm{~L} \text {. Grayish } \\
\text { tint with odor. }\end{array}$ \\
\hline 10/7/09 & $16: 19$ & CNSB09-W-27164 & СРТ/P & SB09 & $32-42$ & 2611 & 10/7/09 & $\begin{array}{l}\text { Depth to water }=7.32 \mathrm{ft} \text {. Depth of } 1 \text {-in. well = } \\
42 \mathrm{ft} \text {. Sample collected by using low-flow } \\
\text { bladder pump positioned at } 37 \mathrm{ft} \text { after purging } \\
\text { of } 3.25 \mathrm{~L} \text {. }\end{array}$ \\
\hline 10/7/09 & $16: 36$ & CNPMP1-W-27165 & MW & PMP1 & $50-60$ & 2611 & 10/7/09 & $\begin{array}{l}\text { Depth to water }=21.08 \mathrm{ft} \text {. Depth of } 0.5 \text {-in. well }= \\
60 \mathrm{ft} \text {. Sample collected by using Waterra pump } \\
\text { positioned at } 55 \mathrm{ft} \text { after purging of } 7 \mathrm{~L} \text {. Light } \\
\text { brown with odor; silty. }\end{array}$ \\
\hline
\end{tabular}


TABLE A.1 (Cont.)

\begin{tabular}{|c|c|c|c|c|c|c|c|c|}
\hline Date & Time & Sample & Type $^{a}$ & Location & $\begin{array}{l}\text { Depth } \\
\text { (ft BGL) }\end{array}$ & $\begin{array}{l}\text { Chain of } \\
\text { Custody }\end{array}$ & $\begin{array}{l}\text { Shipping } \\
\text { Date }\end{array}$ & Sample Description \\
\hline \multicolumn{9}{|c|}{ October 2009 sampling event (cont.) } \\
\hline 10/7/09 & $17: 22$ & CNMW08-W-27156 & MW & MW08 & $38-53$ & 2611 & 10/7/09 & $\begin{array}{l}\text { Depth to water = } 18.85 \mathrm{ft} \text {. Depth of } 2 \text {-in. well = } \\
53 \mathrm{ft} \text {. Sample collected by using low-flow } \\
\text { bladder pump positioned at } 45.5 \mathrm{ft} \text { after purging } \\
\text { of } 8 \mathrm{~L} \text {. }\end{array}$ \\
\hline 10/7/09 & 18:17 & CNQCIR-W-27177b & RI & QC & - & 2611 & 10/7/09 & $\begin{array}{l}\text { Rinsate of decontaminated sampling line after } \\
\text { collection of sample CNMW08-W-27156. }\end{array}$ \\
\hline 10/7/09 & $18: 30$ & CNQCTB-W-27178b & TB & $\mathrm{QC}$ & - & 2611 & 10/7/09 & $\begin{array}{l}\text { Trip blank sent to the AGEM Laboratory for } \\
\text { organic analysis with water samples listed on } \\
\text { COCs } 2610 \text { and } 2611 \text { and to TestAmerica for } \\
\text { verification organic analysis with samples listed } \\
\text { on COC } 2613 \text {. }\end{array}$ \\
\hline 10/7/09 & 18:31 & CNQCTB-W-27178A & TB & QC & - & 2615 & 10/8/09 & $\begin{array}{l}\text { Trip blank sent to the AGEM Laboratory for } \\
\text { organic analysis with water samples listed on } \\
\text { COC } 2615 \text {. }\end{array}$ \\
\hline 10/8/09 & 9:48 & CNSB05-W-27161 & СРТ/P & SB05 & $32-42$ & 2615 & 10/8/09 & $\begin{array}{l}\text { Depth to water }=11.12 \mathrm{ft} \text {. Depth of } 1 \text {-in. well = } \\
42 \mathrm{ft} \text {. Sample collected by using low-flow } \\
\text { bladder pump positioned at } 37 \mathrm{ft} \text { after purging } \\
\text { of } 16 \mathrm{~L} \text {. }\end{array}$ \\
\hline 10/8/09 & $11: 10$ & CNMW01-W-27149 & MW & MW01 & $54.5-64.5$ & 2615 & 10/8/09 & $\begin{array}{l}\text { Depth to water = } 10.31 \mathrm{ft} \text {. Depth of } 4 \text {-in. well = } \\
64.5 \mathrm{ft} \text {. Sample collected by using low-flow } \\
\text { bladder pump positioned at } 59.5 \mathrm{ft} \text { after purging } \\
\text { of } 6 \mathrm{~L} \text {. }\end{array}$ \\
\hline 10/8/09 & $12: 20$ & CNMW02-W-27150 & MW & MW02 & $49.5-59.5$ & 2615 & 10/8/09 & $\begin{array}{l}\text { Depth to water = } 20.98 \mathrm{ft} \text {. Depth of } 4 \text {-in. well = } \\
59.5 \mathrm{ft} \text {. Sample collected by using low-flow } \\
\text { bladder pump positioned at } 54.5 \mathrm{ft} \text { after purging } \\
\text { of } 8 \mathrm{~L} \text {. Light gray; offensive odor. }\end{array}$ \\
\hline 10/8/09 & $12: 34$ & CNSB08-W-27163 & СРТ/P & SB08 & $52-62$ & 2615 & 10/8/09 & $\begin{array}{l}\text { Depth to water = } 18.51 \mathrm{ft} \text {. Depth of } 1 \text {-in. well = } \\
62 \mathrm{ft} \text {. Sample collected by using low-flow } \\
\text { bladder pump positioned at } 57 \mathrm{ft} \text { after purging } \\
\text { of } 3 \mathrm{~L} \text {. }\end{array}$ \\
\hline 10/8/09 & $13: 41$ & CNSB04-W-27160 & СРТ/P & SB04 & $51-61$ & 2615 & 10/8/09 & $\begin{array}{l}\text { Depth to water }=21.73 \mathrm{ft} \text {. Depth of } 1 \text {-in. well }= \\
61 \mathrm{ft} \text {. Sample collected by using low-flow } \\
\text { bladder pump positioned at } 56 \mathrm{ft} \text { after purging } \\
\text { of } 2 \mathrm{~L} \text {. }\end{array}$ \\
\hline
\end{tabular}


TABLE A.1 (Cont.)

\begin{tabular}{|c|c|c|c|c|c|c|c|c|}
\hline Date & Time & Sample & Type $^{\mathrm{a}}$ & Location & $\begin{array}{l}\text { Depth } \\
\text { (ft BGL) }\end{array}$ & $\begin{array}{l}\text { Chain of } \\
\text { Custody }\end{array}$ & $\begin{array}{l}\text { Shipping } \\
\text { Date }\end{array}$ & Sample Description \\
\hline \multicolumn{9}{|c|}{ October 2009 sampling event (cont.) } \\
\hline 10/8/09 & $13: 42$ & CNPMP5-W-27169 & MW & PMP5 & $50-60$ & 2615 & 10/8/09 & $\begin{array}{l}\text { Depth to water = } 21.73 \mathrm{ft} \text {. Depth of 1-in. well = } \\
60 \mathrm{ft} \text {. Sample collected by using low-flow } \\
\text { bladder pump positioned at } 55 \mathrm{ft} \text { after purging } \\
\text { of } 2.4 \mathrm{~L} \text {. Light brown in color. }\end{array}$ \\
\hline
\end{tabular}

a Sample types: CPT/P, piezometer; MW, monitoring well; RI, rinsate; TB, trip blank.

b Quality control sample. 
Appendix B:

Waste Characterization and Disposal Documentation 


\section{Sample Condition Upon Receipt}

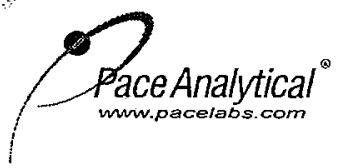

Client Name: tCW Project \# Cock709

Courier: $\square$ Fed Ex $\square$ UPS $\square$ USPS $\square$ Client $\square$ Commercial $\square$ pace Other Tracking \#: 555876829061

Custody Seal on Cooler/Box Present: $\succeq$ yes $\square$ no Seals intact: $\square$ yes $\square$ no

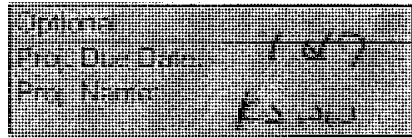

Packing Material: $\square$ Bubble Wrap $\square$ Bubble Bags $\square$ None $\square$ Other

\begin{tabular}{|c|c|c|c|}
\hline Thermometer Used & Type of Ice: Wet & Blue None & $\square$ Samples on ice, cooling process has begun \\
\hline Cooler Temperature & Biological Tissue i & is Frozen: Yes No & $\begin{array}{l}\text { Date and Initialsof person examining } \\
\text { contents: } 1 / 25\end{array}$ \\
\hline Temp should be above freezing to $6^{\circ} \mathrm{C}$ & & Comments: & \\
\hline Chain of Custody Present: & שres $\square$ No $\square \mathrm{N} / \mathrm{A}$ & 1. & \\
\hline Chain of Custody Filled Out: & Gres $\square$ No $\square \mathrm{N} / \mathrm{A}$ & 2. & \\
\hline Chain of Custody Relinquished: & GYes $\square$ No $\quad \square \mathrm{N} / \mathrm{A}$ & 3. & \\
\hline Sampler Name \& Signature on COC: & EYes $\square$ No $\square \mathrm{N} / \mathrm{A}$ & 4. & \\
\hline Samples Arrived within Hold Time: & 七res $\square$ No $\square \mathrm{N} / \mathrm{A}$ & 5. & \\
\hline Short Hold Time Analysis ( $<72 \mathrm{hr})$ : & $\square$ Yes $\square$ No $\square \mathrm{N} / \mathrm{A}$ & $\mathrm{NO}_{3}$ & \\
\hline Rush Turn Around Time Requested: & $\square$ Yes $\square^{\prime}$ No $\quad \square \mathrm{N} / \mathrm{A}$ & 7. & \\
\hline Sufficient Volume: & EYes $\square$ No $\square \mathrm{N} / \mathrm{A}$ & 8. & \\
\hline $\begin{array}{l}\text { Correct Containers Used: } \\
\text {-Pace Containers Used: }\end{array}$ & 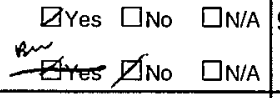 & 9. & \\
\hline Containers Intact: & $\square$ Yes $\square$ No $\quad \square \mathrm{N} / \mathrm{A}$ & 10. & \\
\hline Filtered volume received for Dissolved tests & $\square$ Yes $\square$ No $\quad \square \mathrm{N} / \mathrm{A}$ & 11. & \\
\hline $\begin{array}{l}\text { Sample Labels match COC: } \\
\text {-Includes date/time/ID/Analysis Matrix: } \\
\end{array}$ & 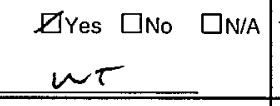 & $\begin{array}{l}12 . \\
\text { AU SAMPCES }\end{array}$ & COLEOTED a/24 SCCORDOWU TO \\
\hline $\begin{array}{l}\text { All containers needing preservation have been checked. } \\
\text { All containers needing preservation are found to be in } \\
\text { compliance with EPA recommendation. }\end{array}$ & $\begin{array}{lll}\square \text { Yes } & \square \text { No } & \square_{N / A} \\
\square \text { Yes } & \square \text { No } & \square_{N / A}\end{array}$ & 13. UABELS & \\
\hline exceptions: NOA, coliform, TOC, O\&G, WI-DRO (water) & $\forall$ Yres $\square$ No & $\begin{array}{l}\text { Initial when } \\
\text { completed }\end{array}$ & $\begin{array}{l}\text { Lot \# of added } \\
\text { preservative }\end{array}$ \\
\hline Samples checked for dechlorination: & पYes $\square$ No $\quad \square \mathrm{N} / \mathrm{A}$ & 14. & \\
\hline Headspace in VOA Vials $(>6 \mathrm{~mm})$ : & 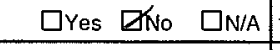 & 15. & \\
\hline $\begin{array}{l}\text { Trip Blank Present: } \\
\text { Trip Blank Custody Seals Present } \\
\text { Pace Trip Blank Lot \# (if purchased): }\end{array}$ & $\begin{array}{lll}\square^{\prime} \text { Yes } & \square \text { No } & \square \mathrm{N} / \mathrm{A} \\
\text {ZZTes } & \square \mathrm{No} & \square \mathrm{N} / \mathrm{A}\end{array}$ & 16. & \\
\hline
\end{tabular}

Pace Trip Blank Lot \# (if purchased):

Client Notification/Resolution: $\quad$ Copy COC to Client? $\quad \mathrm{Y} / \mathrm{N} \quad$ Field Data Required? $\mathrm{Y} / \mathrm{N}$

Person Contacted: Travis Kamler Date/Time: 9-25.09

comments/Resolution: Per cllent-aul samples collected on 9-24-09, ypt

Project Manager Review: $\quad$ Ap \& $9-28-09$

Date:

Note: Whenever there is a discrepancy affecting North Carolina compliance samples, a copy of this form will be sent to the North Carolina DEHNR Certification Office (i.e out of hold, incorrect preservative, out of temp, incorrect containers) 


\section{SAMPLE ACKNOWLEDGMENT}

$\begin{array}{ll}\text { Samples Submitted By: } & \text { TCW Construction Inc } \\ \text { Client Project ID: } & \text { Kansas Waste Water } \\ \text { Client PO\#: } & \text { Credit Card }\end{array}$

Client PO\#:

\author{
Pace Project Manager: \\ Pace Analytical Project ID: \\ Samples Received: \\ Estimated Completion:
}

Trudy Gipson

Phone 1(913)563-1405

trudy.gipson@pacelabs.com

6066709

September 25, 2009

October 07, 2009

\begin{tabular}{|c|c|c|c|c|}
\hline Customer Sample ID & $\begin{array}{l}\text { Pace Analytical } \\
\text { Lab ID }\end{array}$ & Matrix & $\begin{array}{l}\text { Date/Time } \\
\text { Collected }\end{array}$ & Method \\
\hline AGPURGE-W-924091 & 6066709001 & Water & 09/24/09 08:00 & $\begin{array}{l}300.0 \text { IC Anions } \\
504 \text { GCS EDB and DBCP } \\
8260 \mathrm{MSV}\end{array}$ \\
\hline BAPURGE-W-924092 & 6066709002 & Water & 09/24/09 11:15 & $\begin{array}{l}300.0 \text { IC Anions } \\
504 \text { GCS EDB and DBCP } \\
8260 \mathrm{MSV}\end{array}$ \\
\hline CNPURGE-W-924093 & 6066709003 & Water & 09/24/09 12:40 & $\begin{array}{l}\text { 300.0 IC Anions } \\
504 \text { GCS EDB and DBCP } \\
8260 \text { MSV }\end{array}$ \\
\hline EUPURGE-W-924094 & 6066709004 & Water & 09/24/09 13:33 & $\begin{array}{l}300.0 \text { IC Anions } \\
504 \text { GCS EDB and DBCP } \\
8260 \mathrm{MSV}\end{array}$ \\
\hline MRPURGE-W-924095 & 6066709005 & Water & 09/24/09 14:22 & $\begin{array}{l}300.0 \text { IC Anions } \\
504 \text { GCS EDB and DBCP } \\
8260 \text { MSV }\end{array}$ \\
\hline QCTB-W-924096 & 6066709006 & Water & 09/24/09 16:40 & $8260 \mathrm{MSV}$ \\
\hline
\end{tabular}


October 13, 2009

Mr. Travis Kamler

TCW Construction Inc

141 M Street

Lincoln, NE 68508

\section{RE: Project: Kansas Waste Water}

Pace Project No.: 6066709

Dear Mr. Kamler:

Enclosed are the analytical results for sample(s) received by the laboratory on September 25, 2009. The results relate only to the samples included in this report. Results reported herein conform to the most current NELAC standards, where applicable, unless otherwise narrated in the body of the report.

If you have any questions concerning this report, please feel free to contact me.

Sincerely,

$$
\text { Sudy } \sin _{i=0}
$$

Trudy Gipson

trudy.gipson@pacelabs.com

Project Manager

Enclosures

cc: Mr. David Surgnier 


\section{CERTIFICATIONS}

Project:

Kansas Waste Water

Pace Project No.:

6066709

Kansas Certification IDs

Washington Certification \#: C2069

Utah Certification \#: 9135995665

Texas Certification \#: T104704407-08-TX

Oregon Certification \#: KS200001

Oklahoma Certification \#: 9205/9935

Nevada Certification \#: KS000212008A
Louisiana Certification \#: 03055

Kansas/NELAP Certification \#: E-10116

lowa Certification \#: 118

Illinois Certification \#: 001191

Arkansas Certification \#: 05-008-0

A2LA Certification \#: 2456.01

This report shall not be reproduced, except in full, without the written consent of Pace Analytical Services, Inc.. 
SAMPLE SUMMARY

Project: Kansas Waste Water

Pace Project No.: 6066709

\begin{tabular}{|c|c|c|c|c|}
\hline Lab ID & Sample ID & Matrix & Date Collected & Date Received \\
\hline 6066709001 & AGPURGE-W-924091 & Water & 09/24/09 08:00 & 09/25/09 08:50 \\
\hline 6066709002 & BAPURGE-W-924092 & Water & 09/24/09 11:15 & 09/25/09 08:50 \\
\hline 6066709003 & CNPURGE-W-924093 & Water & 09/24/09 12:40 & 09/25/09 08:50 \\
\hline 6066709004 & EUPURGE-W-924094 & Water & 09/24/09 13:33 & 09/25/09 08:50 \\
\hline 6066709005 & MRPURGE-W-924095 & Water & 09/24/09 14:22 & 09/25/09 08:50 \\
\hline 6066709006 & QCTB-W-924096 & Water & 09/24/09 16:40 & 09/25/09 08:50 \\
\hline
\end{tabular}


SAMPLE ANALYTE COUNT

Project: Kansas Waste Water

Pace Project No.: 6066709

\begin{tabular}{|c|c|c|c|c|}
\hline Lab ID & Sample ID & Method & Analysts & $\begin{array}{l}\text { Analytes } \\
\text { Reported }\end{array}$ \\
\hline \multirow[t]{3}{*}{6066709001} & AGPURGE-W-924091 & EPA 300.0 & RAB & 1 \\
\hline & & EPA 5030B/8260 & NPM & 70 \\
\hline & & EPA 504.1 & WAW & 1 \\
\hline \multirow[t]{3}{*}{6066709002} & BAPURGE-W-924092 & EPA 300.0 & RAB & 1 \\
\hline & & EPA 5030B/8260 & NPM & 70 \\
\hline & & EPA 504.1 & WAW & 1 \\
\hline \multirow[t]{3}{*}{6066709003} & CNPURGE-W-924093 & EPA 300.0 & RAB & 1 \\
\hline & & EPA 5030B/8260 & NPM & 70 \\
\hline & & EPA 504.1 & WAW & 1 \\
\hline \multirow[t]{3}{*}{6066709004} & EUPURGE-W-924094 & EPA 300.0 & RAB & 1 \\
\hline & & EPA 5030B/8260 & NPM & 70 \\
\hline & & EPA 504.1 & WAW & 1 \\
\hline \multirow[t]{3}{*}{6066709005} & MRPURGE-W-924095 & EPA 300.0 & RAB & 1 \\
\hline & & EPA 5030B/8260 & NPM & 70 \\
\hline & & EPA 504.1 & WAW & 1 \\
\hline 6066709006 & QCTB-W-924096 & EPA 5030B/8260 & NPM & 70 \\
\hline
\end{tabular}




\section{ANALYTICAL RESULTS}

Project: Kansas Waste Water

Pace Project No.: 6066709

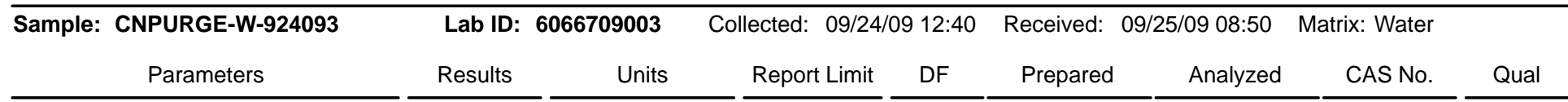

504 GCS EDB and DBCP

1,2-Dibromoethane (EDB)

\section{MSV}

Acetone

Benzene

Bromobenzene

Bromochloromethane

Bromodichloromethane

Bromoform

Bromomethane

2-Butanone (MEK)

n-Butylbenzene

sec-Butylbenzene

tert-Butylbenzene

Carbon disulfide

Carbon tetrachloride

Chlorobenzene

Chloroethane

Chloroform

Chloromethane

2-Chlorotoluene

4-Chlorotoluene

1,2-Dibromo-3-chloropropane

Dibromochloromethane

1,2-Dibromoethane (EDB)

Dibromomethane

1,2-Dichlorobenzene

1,3-Dichlorobenzene

1,4-Dichlorobenzene

Dichlorodifluoromethane

1,1-Dichloroethane

1,2-Dichloroethane

1,2-Dichloroethene (Total)

1,1-Dichloroethene

cis-1,2-Dichloroethene

trans-1,2-Dichloroethene

1,2-Dichloropropane

1,3-Dichloropropane

2,2-Dichloropropane

1,1-Dichloropropene

cis-1,3-Dichloropropene

trans-1,3-Dichloropropene

Ethylbenzene

Hexachloro-1,3-butadiene

2-Hexanone

Isopropylbenzene (Cumene)

p-Isopropyltoluene

Date: 10/13/2009 03:25 PM
Analytical Method: EPA 504.1 Preparation Method: EPA 504.1

$$
\begin{array}{lllllllll}
\text { ND ug/L } & 0.046 & 1 & 10 / 08 / 09 & 00: 00 & 10 / 10 / 09 & 04: 04 & 106-93-4
\end{array}
$$

Analytical Method: EPA 5030B/8260

\begin{tabular}{|c|c|c|c|c|}
\hline ND ug/L & 10.0 & 1 & 09/28/09 21:37 & $67-64-1$ \\
\hline ND ug/L & 1.0 & 1 & 09/28/09 21:37 & $71-43-2$ \\
\hline ND ug/L & 1.0 & 1 & 09/28/09 21:37 & $108-86-1$ \\
\hline ND ug/L & 1.0 & 1 & 09/28/09 21:37 & $74-97-5$ \\
\hline ND ug/L & 1.0 & 1 & 09/28/09 21:37 & $75-27-4$ \\
\hline ND ug/L & 1.0 & 1 & 09/28/09 21:37 & $75-25-2$ \\
\hline ND ug/L & 1.0 & 1 & 09/28/09 21:37 & $74-83-9$ \\
\hline ND ug/L & 10.0 & 1 & 09/28/09 21:37 & $78-93-3$ \\
\hline ND ug/L & 1.0 & 1 & 09/28/09 21:37 & $104-51-8$ \\
\hline ND ug/L & 1.0 & 1 & 09/28/09 21:37 & $135-98-8$ \\
\hline ND ug/L & 1.0 & 1 & 09/28/09 21:37 & $98-06-6$ \\
\hline ND ug/L & 5.0 & 1 & 09/28/09 21:37 & $75-15-0$ \\
\hline ND ug/L & 1.0 & 1 & 09/28/09 21:37 & $56-23-5$ \\
\hline ND ug/L & 1.0 & 1 & 09/28/09 21:37 & $108-90-7$ \\
\hline ND ug/L & 1.0 & 1 & 09/28/09 21:37 & $75-00-3$ \\
\hline ND ug/L & 1.0 & 1 & 09/28/09 21:37 & $67-66-3$ \\
\hline ND ug/L & 1.0 & 1 & 09/28/09 21:37 & $74-87-3$ \\
\hline ND ug/L & 1.0 & 1 & 09/28/09 21:37 & $95-49-8$ \\
\hline ND ug/L & 1.0 & 1 & 09/28/09 21:37 & $106-43-4$ \\
\hline ND ug/L & 2.5 & 1 & 09/28/09 21:37 & $96-12-8$ \\
\hline ND ug/L & 1.0 & 1 & 09/28/09 21:37 & $124-48-1$ \\
\hline ND ug/L & 1.0 & 1 & 09/28/09 21:37 & $106-93-4$ \\
\hline ND ug/L & 1.0 & 1 & 09/28/09 21:37 & $74-95-3$ \\
\hline ND ug/L & 1.0 & 1 & 09/28/09 21:37 & $95-50-1$ \\
\hline ND ug/L & 1.0 & 1 & 09/28/09 21:37 & 541-73-1 \\
\hline ND ug/L & 1.0 & 1 & 09/28/09 21:37 & $106-46-7$ \\
\hline ND ug/L & 1.0 & 1 & 09/28/09 21:37 & $75-71-8$ \\
\hline ND ug/L & 1.0 & 1 & 09/28/09 21:37 & $75-34-3$ \\
\hline ND ug/L & 1.0 & 1 & 09/28/09 21:37 & $107-06-2$ \\
\hline ND ug/L & 1.0 & 1 & 09/28/09 21:37 & $540-59-0$ \\
\hline ND ug/L & 1.0 & 1 & 09/28/09 21:37 & $75-35-4$ \\
\hline ND ug/L & 1.0 & 1 & 09/28/09 21:37 & $156-59-2$ \\
\hline ND ug/L & 1.0 & 1 & 09/28/09 21:37 & $156-60-5$ \\
\hline ND ug/L & 1.0 & 1 & 09/28/09 21:37 & $78-87-5$ \\
\hline ND ug/L & 1.0 & 1 & 09/28/09 21:37 & $142-28-9$ \\
\hline ND ug/L & 1.0 & 1 & 09/28/09 21:37 & $594-20-7$ \\
\hline ND ug/L & 1.0 & 1 & 09/28/09 21:37 & $563-58-6$ \\
\hline ND ug/L & 1.0 & 1 & 09/28/09 21:37 & $10061-01-5$ \\
\hline ND ug/L & 1.0 & 1 & 09/28/09 21:37 & $10061-02-6$ \\
\hline ND ug/L & 1.0 & 1 & 09/28/09 21:37 & $100-41-4$ \\
\hline ND ug/L & 1.0 & 1 & 09/28/09 21:37 & $87-68-3$ \\
\hline ND ug/L & 10.0 & 1 & 09/28/09 21:37 & $591-78-6$ \\
\hline ND ug/L & 1.0 & 1 & 09/28/09 21:37 & $98-82-8$ \\
\hline ND ug/L & 1.0 & 1 & 09/28/09 21:37 & $99-87-6$ \\
\hline
\end{tabular}

REPORT OF LABORATORY ANALYSIS

Page 9 of 23

This report shall not be reproduced, except in full,

without the written consent of Pace Analytical Services, Inc.. 


\section{ANALYTICAL RESULTS}

Project: Kansas Waste Water

Pace Project No.: 6066709

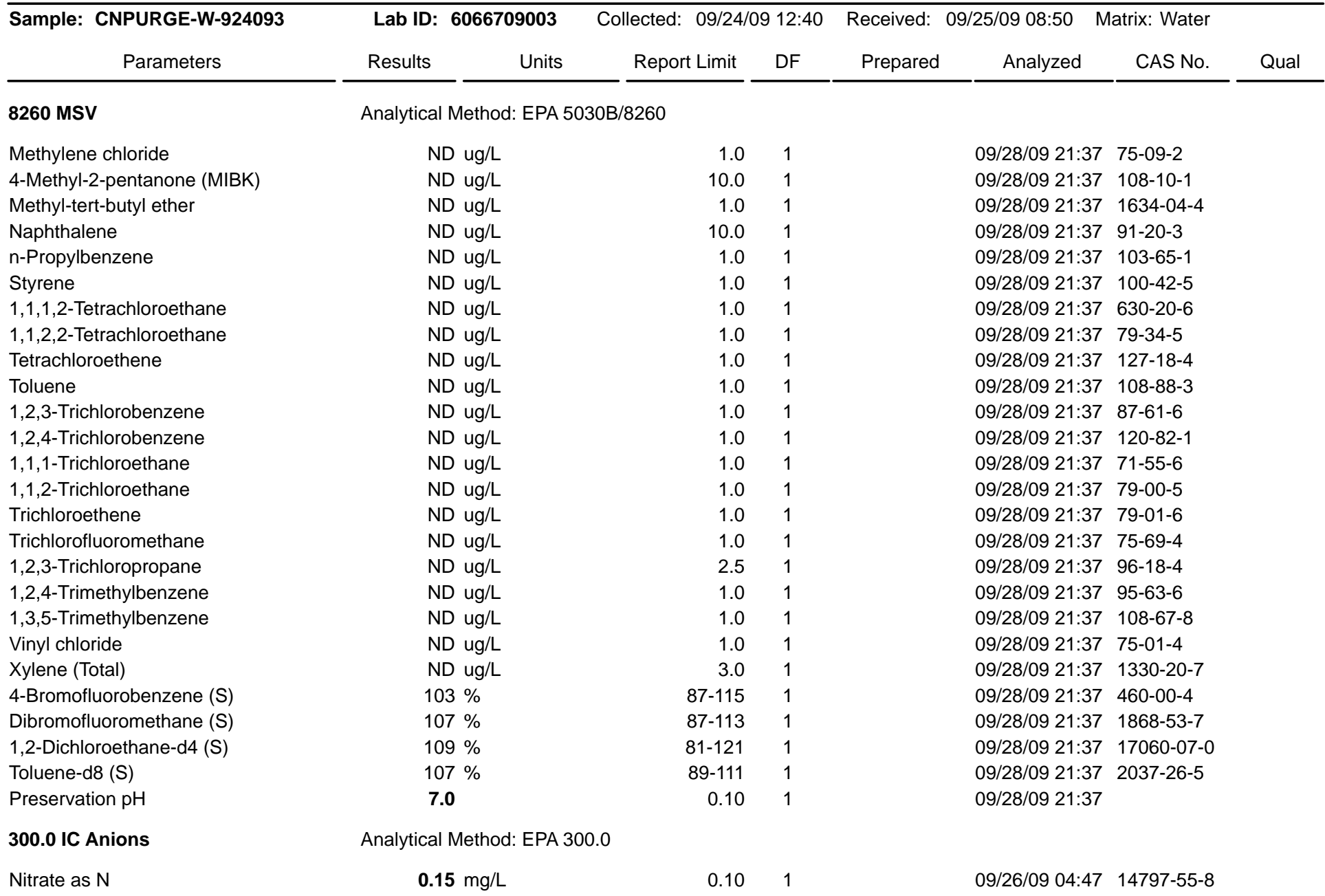

This report shall not be reproduced, except in full, 


\section{ANALYTICAL RESULTS}

Project: Kansas Waste Water

Pace Project No.: 6066709

\begin{tabular}{|c|c|c|c|c|c|c|c|c|}
\hline \multirow{2}{*}{$\begin{array}{c}\text { Sample: QCTB-W-924096 } \\
\text { Parameters }\end{array}$} & \multirow{2}{*}{\multicolumn{2}{|c|}{$\begin{array}{lr}\text { Lab ID: } & 6066709006 \\
& \\
\text { Results } & \text { Units }\end{array}$}} & \multicolumn{2}{|c|}{ Collected: 09/24/09 16:40 } & \multirow{2}{*}{$\begin{array}{l}\text { Received: } \\
\text { Prepared }\end{array}$} & \multirow{2}{*}{$\begin{array}{r}\text { 09/25/09 08:50 } \\
\text { Analyzed }\end{array}$} & \multirow{2}{*}{$\begin{array}{l}\text { Matrix: Water } \\
\text { CAS No. }\end{array}$} & \multirow[b]{2}{*}{ Qual } \\
\hline & & & Report Limit & DF & & & & \\
\hline 8260 MSV & Analytical & Method: EPA 5 & $30 \mathrm{~B} / 8260$ & & & & & \\
\hline Acetone & 15. & $4 \mathrm{ug} / \mathrm{L}$ & 10.0 & 1 & & 09/28/09 22:23 & $67-64-1$ & \\
\hline Benzene & $\mathrm{NL}$ & ug/L & 1.0 & 1 & & 09/28/09 22:23 & $71-43-2$ & \\
\hline Bromobenzene & $\mathrm{NL}$ & $u g / L$ & 1.0 & 1 & & $09 / 28 / 0922: 23$ & $108-86-1$ & \\
\hline Bromochloromethane & $\mathrm{NL}$ & $u g / L$ & 1.0 & 1 & & $09 / 28 / 0922: 23$ & $74-97-5$ & \\
\hline Bromodichloromethane & $\mathrm{NL}$ & ug/L & 1.0 & 1 & & 09/28/09 22:23 & $75-27-4$ & \\
\hline Bromoform & $\mathrm{NL}$ & $u g / L$ & 1.0 & 1 & & $09 / 28 / 0922: 23$ & $75-25-2$ & \\
\hline Bromomethane & $\mathrm{NL}$ & $u g / L$ & 1.0 & 1 & & $09 / 28 / 0922: 23$ & $74-83-9$ & \\
\hline 2-Butanone (MEK) & $\mathrm{NL}$ & ug/L & 10.0 & 1 & & 09/28/09 22:23 & $78-93-3$ & \\
\hline n-Butylbenzene & $\mathrm{NI}$ & ug/L & 1.0 & 1 & & 09/28/09 22:23 & $104-51-8$ & \\
\hline sec-Butylbenzene & $\mathrm{NL}$ & $u g / L$ & 1.0 & 1 & & $09 / 28 / 0922: 23$ & $135-98-8$ & \\
\hline tert-Butylbenzene & $\mathrm{NL}$ & ug/L & 1.0 & 1 & & 09/28/09 22:23 & $98-06-6$ & \\
\hline Carbon disulfide & $\mathrm{NI}$ & ug/L & 5.0 & 1 & & 09/28/09 22:23 & $75-15-0$ & \\
\hline Carbon tetrachloride & $\mathrm{NL}$ & $u g / L$ & 1.0 & 1 & & $09 / 28 / 0922: 23$ & $56-23-5$ & \\
\hline Chlorobenzene & $\mathrm{NL}$ & ug/L & 1.0 & 1 & & 09/28/09 22:23 & $108-90-7$ & \\
\hline Chloroethane & $\mathrm{NL}$ & $u g / L$ & 1.0 & 1 & & 09/28/09 22:23 & $75-00-3$ & \\
\hline Chloroform & $\mathrm{NL}$ & $u g / L$ & 1.0 & 1 & & $09 / 28 / 0922: 23$ & $67-66-3$ & \\
\hline Chloromethane & $\mathrm{NL}$ & ug/L & 1.0 & 1 & & 09/28/09 22:23 & $74-87-3$ & \\
\hline 2-Chlorotoluene & $\mathrm{NL}$ & ug/L & 1.0 & 1 & & 09/28/09 22:23 & $95-49-8$ & \\
\hline 4-Chlorotoluene & $\mathrm{NL}$ & $u g / L$ & 1.0 & 1 & & $09 / 28 / 0922: 23$ & $106-43-4$ & \\
\hline 1,2-Dibromo-3-chloropropane & $\mathrm{NL}$ & ug/L & 2.5 & 1 & & 09/28/09 22:23 & $96-12-8$ & \\
\hline Dibromochloromethane & $\mathrm{NL}$ & $u g / L$ & 1.0 & 1 & & 09/28/09 22:23 & $124-48-1$ & \\
\hline 1,2-Dibromoethane (EDB) & $\mathrm{NL}$ & ug/L & 1.0 & 1 & & $09 / 28 / 0922: 23$ & $106-93-4$ & \\
\hline Dibromomethane & $\mathrm{NL}$ & $u g / L$ & 1.0 & 1 & & $09 / 28 / 0922: 23$ & $74-95-3$ & \\
\hline 1,2-Dichlorobenzene & $\mathrm{NL}$ & $u g / L$ & 1.0 & 1 & & 09/28/09 22:23 & $95-50-1$ & \\
\hline 1,3-Dichlorobenzene & $\mathrm{NI}$ & ug/L & 1.0 & 1 & & 09/28/09 22:23 & $541-73-1$ & \\
\hline 1,4-Dichlorobenzene & $\mathrm{NL}$ & $u g / L$ & 1.0 & 1 & & $09 / 28 / 0922: 23$ & $106-46-7$ & \\
\hline Dichlorodifluoromethane & $\mathrm{NL}$ & $u g / L$ & 1.0 & 1 & & 09/28/09 22:23 & $75-71-8$ & \\
\hline 1,1-Dichloroethane & $\mathrm{NI}$ & ug/L & 1.0 & 1 & & 09/28/09 22:23 & $75-34-3$ & \\
\hline 1,2-Dichloroethane & $\mathrm{NL}$ & $u g / L$ & 1.0 & 1 & & $09 / 28 / 0922: 23$ & $107-06-2$ & \\
\hline 1,2-Dichloroethene (Total) & $\mathrm{NL}$ & $u g / L$ & 1.0 & 1 & & $09 / 28 / 0922: 23$ & $540-59-0$ & \\
\hline 1,1-Dichloroethene & $\mathrm{NL}$ & $u g / L$ & 1.0 & 1 & & 09/28/09 22:23 & $75-35-4$ & \\
\hline cis-1,2-Dichloroethene & $\mathrm{NL}$ & $u g / L$ & 1.0 & 1 & & $09 / 28 / 0922: 23$ & $156-59-2$ & \\
\hline trans-1,2-Dichloroethene & $\mathrm{NL}$ & $u g / L$ & 1.0 & 1 & & $09 / 28 / 0922: 23$ & $156-60-5$ & \\
\hline 1,2-Dichloropropane & $\mathrm{NL}$ & ug/L & 1.0 & 1 & & 09/28/09 22:23 & $78-87-5$ & \\
\hline 1,3-Dichloropropane & $\mathrm{NL}$ & $u g / L$ & 1.0 & 1 & & 09/28/09 22:23 & $142-28-9$ & \\
\hline 2,2-Dichloropropane & $\mathrm{NL}$ & $u g / L$ & 1.0 & 1 & & $09 / 28 / 0922: 23$ & $594-20-7$ & \\
\hline 1,1-Dichloropropene & $\mathrm{NL}$ & $u g / L$ & 1.0 & 1 & & 09/28/09 22:23 & $563-58-6$ & \\
\hline cis-1,3-Dichloropropene & $\mathrm{NL}$ & $u g / L$ & 1.0 & 1 & & $09 / 28 / 0922: 23$ & $10061-01-5$ & \\
\hline trans-1,3-Dichloropropene & $\mathrm{NL}$ & $u g / L$ & 1.0 & 1 & & $09 / 28 / 0922: 23$ & $10061-02-6$ & \\
\hline Ethylbenzene & $\mathrm{NL}$ & $u g / L$ & 1.0 & 1 & & 09/28/09 22:23 & $100-41-4$ & \\
\hline Hexachloro-1,3-butadiene & $\mathrm{NL}$ & $u g / L$ & 1.0 & 1 & & $09 / 28 / 0922: 23$ & $87-68-3$ & \\
\hline 2-Hexanone & $\mathrm{NL}$ & $u g / L$ & 10.0 & 1 & & $09 / 28 / 0922: 23$ & $591-78-6$ & \\
\hline Isopropylbenzene (Cumene) & $\mathrm{NL}$ & ug/L & 1.0 & 1 & & 09/28/09 22:23 & $98-82-8$ & \\
\hline p-Isopropyltoluene & $\mathrm{NL}$ & $u g / L$ & 1.0 & 1 & & $09 / 28 / 0922: 23$ & $99-87-6$ & \\
\hline Methylene chloride & $\mathrm{NL}$ & $u g / L$ & 1.0 & 1 & & $09 / 28 / 0922: 23$ & $75-09-2$ & \\
\hline 4-Methyl-2-pentanone (MIBK) & $\mathrm{NL}$ & $u g / L$ & 10.0 & 1 & & $09 / 28 / 0922: 23$ & $108-10-1$ & \\
\hline Methyl-tert-butyl ether & $\mathrm{NL}$ & $\mathrm{ug} / \mathrm{L}$ & 1.0 & 1 & & $09 / 28 / 0922: 23$ & $1634-04-4$ & \\
\hline
\end{tabular}

This report shall not be reproduced, except in full, without the written consent of Pace Analytical Services, Inc.. 


\section{ANALYTICAL RESULTS}

Project: Kansas Waste Water

Pace Project No.: 6066709

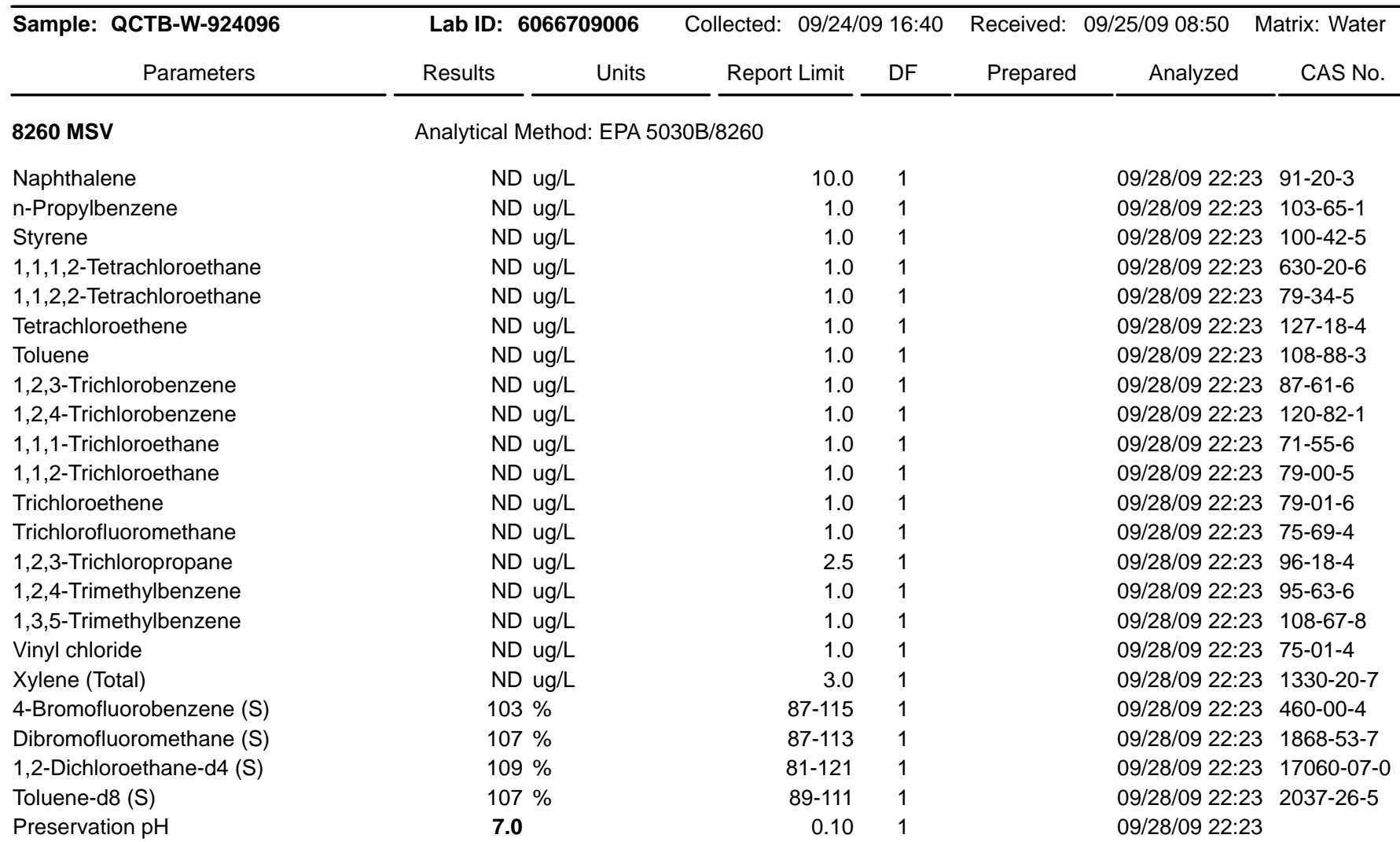

This report shall not be reproduced, except in full, 


\section{QUALITY CONTROL DATA}

Project: Kansas Waste Water

Pace Project No.: 6066709

\begin{tabular}{llll}
\hline QC Batch: & WETA/10995 & Analysis Method: & EPA 300.0 \\
QC Batch Method: & EPA 300.0 & Analysis Description: & 300.0 IC Anions
\end{tabular}

Associated Lab Samples: $\quad$ 6066709001, 6066709002, 6066709003, 6066709004, 6066709005

\begin{tabular}{|c|c|c|c|c|c|}
\hline METHOD BLANK: 541949 & & Matrix: & Nater & & \\
\hline Associated Lab Samples: & 6066709001,60667090 & 709003,6066 & 09004,60667 & 9005 & \\
\hline Parameter & Units & $\begin{array}{l}\text { Blank } \\
\text { Result }\end{array}$ & $\begin{array}{l}\text { Reporting } \\
\text { Limit }\end{array}$ & Analyzed & Qualifiers \\
\hline Nitrate as $\mathrm{N}$ & $\mathrm{mg} / \mathrm{L}$ & ND & 0.10 & 09/25/09 21:46 & \\
\hline
\end{tabular}

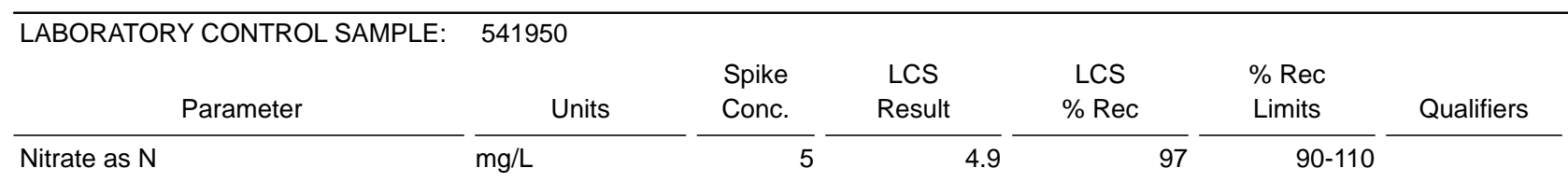

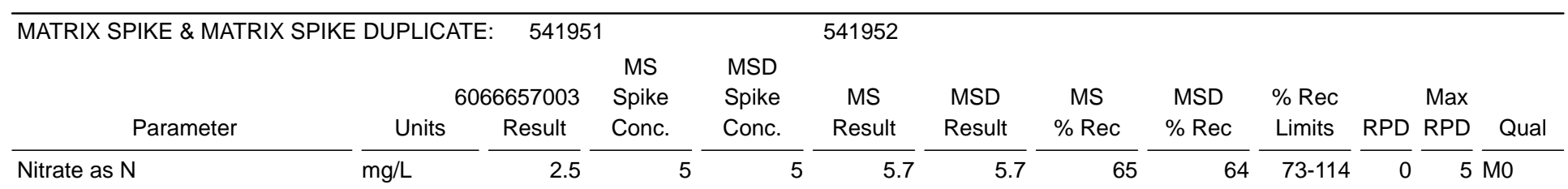

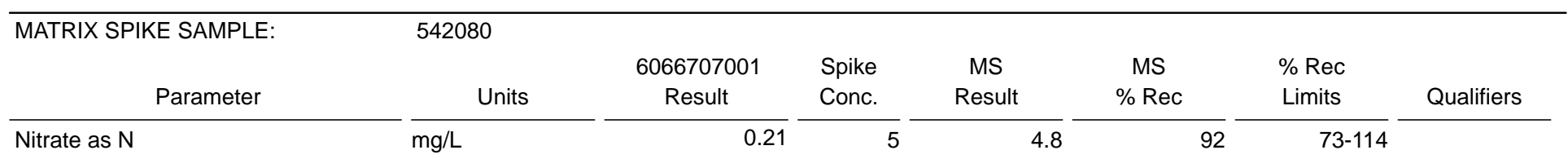




\section{QUALITY CONTROL DATA}

Project: $\quad$ Kansas Waste Water

Pace Project No.: 6066709

\begin{tabular}{llll}
\hline QC Batch: & MSV/23759 & Analysis Method: & EPA 5030B/8260 \\
QC Batch Method: & EPA 5030B/8260 & Analysis Description: & 8260 MSV Water 7 day
\end{tabular}

Associated Lab Samples: $\quad$ 6066709001, 6066709002, 6066709003, 6066709004, 6066709005, 6066709006

\begin{tabular}{|c|c|c|c|c|c|}
\hline METHOD BLANK: 548226 & & Matrix: & Vater & & \\
\hline Associated Lab Samples: & 001,6066709 & 709003,6066 & 09004,60667 & 9005,6066709006 & \\
\hline Parameter & Units & $\begin{array}{l}\text { Blank } \\
\text { Result }\end{array}$ & $\begin{array}{l}\text { Reporting } \\
\text { Limit }\end{array}$ & Analyzed & Qualifiers \\
\hline 1,1,1,2-Tetrachloroethane & $\mathrm{ug} / \mathrm{L}$ & ND & 1.0 & 09/28/09 20:06 & \\
\hline 1,1,1-Trichloroethane & ug/L & ND & 1.0 & 09/28/09 20:06 & \\
\hline 1,1,2,2-Tetrachloroethane & $\mathrm{ug} / \mathrm{L}$ & ND & 1.0 & 09/28/09 20:06 & \\
\hline 1,1,2-Trichloroethane & $\mathrm{ug} / \mathrm{L}$ & ND & 1.0 & 09/28/09 20:06 & \\
\hline 1,1-Dichloroethane & ug/L & ND & 1.0 & 09/28/09 20:06 & \\
\hline 1,1-Dichloroethene & $\mathrm{ug} / \mathrm{L}$ & ND & 1.0 & 09/28/09 20:06 & \\
\hline 1,1-Dichloropropene & $\mathrm{ug} / \mathrm{L}$ & ND & 1.0 & 09/28/09 20:06 & \\
\hline 1,2,3-Trichlorobenzene & ug/L & ND & 1.0 & 09/28/09 20:06 & \\
\hline 1,2,3-Trichloropropane & $\mathrm{ug} / \mathrm{L}$ & ND & 2.5 & 09/28/09 20:06 & \\
\hline 1,2,4-Trichlorobenzene & ug/L & ND & 1.0 & 09/28/09 20:06 & \\
\hline 1,2,4-Trimethylbenzene & $\mathrm{ug} / \mathrm{L}$ & ND & 1.0 & 09/28/09 20:06 & \\
\hline 1,2-Dibromo-3-chloropropane & $\mathrm{ug} / \mathrm{L}$ & ND & 2.5 & 09/28/09 20:06 & \\
\hline 1,2-Dibromoethane (EDB) & ug/L & ND & 1.0 & 09/28/09 20:06 & \\
\hline 1,2-Dichlorobenzene & $\mathrm{ug} / \mathrm{L}$ & ND & 1.0 & 09/28/09 20:06 & \\
\hline 1,2-Dichloroethane & ug/L & ND & 1.0 & 09/28/09 20:06 & \\
\hline 1,2-Dichloroethene (Total) & $\mathrm{ug} / \mathrm{L}$ & ND & 1.0 & 09/28/09 20:06 & \\
\hline 1,2-Dichloropropane & $\mathrm{ug} / \mathrm{L}$ & ND & 1.0 & 09/28/09 20:06 & \\
\hline 1,3,5-Trimethylbenzene & ug/L & ND & 1.0 & 09/28/09 20:06 & \\
\hline 1,3-Dichlorobenzene & ug/L & ND & 1.0 & 09/28/09 20:06 & \\
\hline 1,3-Dichloropropane & $\mathrm{ug} / \mathrm{L}$ & ND & 1.0 & 09/28/09 20:06 & \\
\hline 1,4-Dichlorobenzene & ug/L & ND & 1.0 & 09/28/09 20:06 & \\
\hline 2,2-Dichloropropane & $\mathrm{ug} / \mathrm{L}$ & ND & 1.0 & 09/28/09 20:06 & \\
\hline 2-Butanone (MEK) & $\mathrm{ug} / \mathrm{L}$ & ND & 10.0 & 09/28/09 20:06 & \\
\hline 2-Chlorotoluene & ug/L & ND & 1.0 & 09/28/09 20:06 & \\
\hline 2-Hexanone & $\mathrm{ug} / \mathrm{L}$ & ND & 10.0 & 09/28/09 20:06 & \\
\hline 4-Chlorotoluene & ug/L & ND & 1.0 & 09/28/09 20:06 & \\
\hline 4-Methyl-2-pentanone (MIBK) & $\mathrm{ug} / \mathrm{L}$ & ND & 10.0 & 09/28/09 20:06 & \\
\hline Acetone & $\mathrm{ug} / \mathrm{L}$ & ND & 10.0 & 09/28/09 20:06 & \\
\hline Benzene & $\mathrm{ug} / \mathrm{L}$ & ND & 1.0 & 09/28/09 20:06 & \\
\hline Bromobenzene & $\mathrm{ug} / \mathrm{L}$ & ND & 1.0 & 09/28/09 20:06 & \\
\hline Bromochloromethane & $\mathrm{ug} / \mathrm{L}$ & ND & 1.0 & 09/28/09 20:06 & \\
\hline Bromodichloromethane & $\mathrm{ug} / \mathrm{L}$ & ND & 1.0 & 09/28/09 20:06 & \\
\hline Bromoform & $\mathrm{ug} / \mathrm{L}$ & ND & 1.0 & 09/28/09 20:06 & \\
\hline Bromomethane & ug/L & ND & 1.0 & 09/28/09 20:06 & \\
\hline Carbon disulfide & $\mathrm{ug} / \mathrm{L}$ & ND & 5.0 & 09/28/09 20:06 & \\
\hline Carbon tetrachloride & $\mathrm{ug} / \mathrm{L}$ & ND & 1.0 & 09/28/09 20:06 & \\
\hline Chlorobenzene & ug/L & ND & 1.0 & 09/28/09 20:06 & \\
\hline Chloroethane & $\mathrm{ug} / \mathrm{L}$ & ND & 1.0 & 09/28/09 20:06 & \\
\hline Chloroform & $\mathrm{ug} / \mathrm{L}$ & ND & 1.0 & 09/28/09 20:06 & \\
\hline Chloromethane & ug/L & ND & 1.0 & 09/28/09 20:06 & \\
\hline cis-1,2-Dichloroethene & $\mathrm{ug} / \mathrm{L}$ & ND & 1.0 & 09/28/09 20:06 & \\
\hline cis-1,3-Dichloropropene & ug/L & ND & 1.0 & 09/28/09 20:06 & \\
\hline Dibromochloromethane & $\mathrm{ug} / \mathrm{L}$ & ND & 1.0 & 09/28/09 20:06 & \\
\hline
\end{tabular}




\section{QUALITY CONTROL DATA}

Project: Kansas Waste Water

Pace Project No.: 6066709

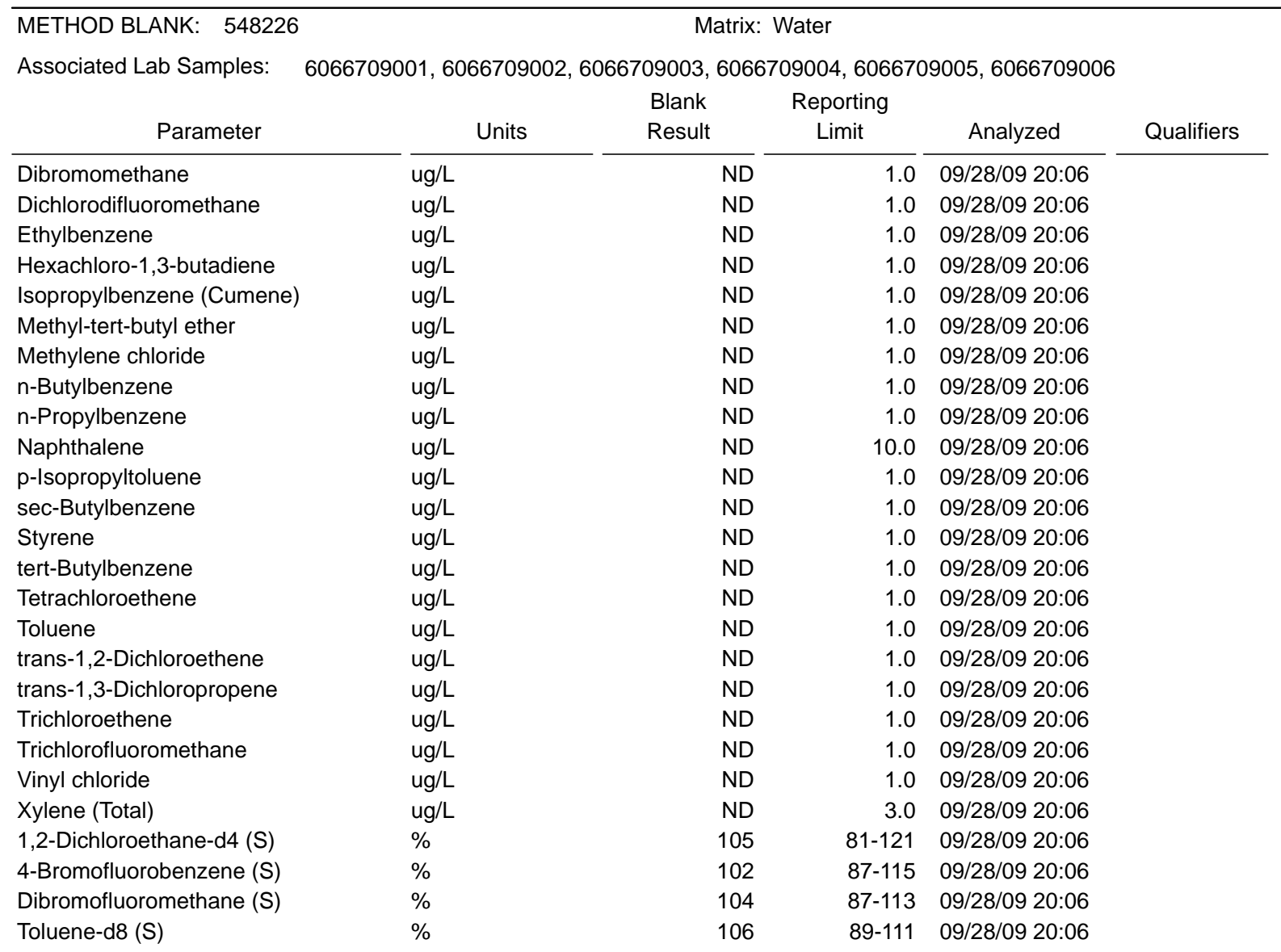

\begin{tabular}{|c|c|c|c|c|c|c|}
\hline \multirow{2}{*}{$\begin{array}{c}\text { LABORATORY CONTROL SAMPLE: } \\
\text { Parameter }\end{array}$} & \multicolumn{6}{|l|}{548227} \\
\hline & Units & $\begin{array}{l}\text { Spike } \\
\text { Conc. }\end{array}$ & $\begin{array}{l}\text { LCS } \\
\text { Result }\end{array}$ & $\begin{array}{l}\text { LCS } \\
\% \operatorname{Rec}\end{array}$ & $\begin{array}{l}\% \text { Rec } \\
\text { Limits }\end{array}$ & Qualifiers \\
\hline 1,1,1,2-Tetrachloroethane & $\mathrm{ug} / \mathrm{L}$ & 10 & 7.6 & 76 & $75-121$ & \\
\hline 1,1,1-Trichloroethane & $\mathrm{ug} / \mathrm{L}$ & 10 & 8.8 & 88 & $73-120$ & \\
\hline 1,1,2,2-Tetrachloroethane & $\mathrm{ug} / \mathrm{L}$ & 10 & 10 & 100 & $73-128$ & \\
\hline 1,1,2-Trichloroethane & $\mathrm{ug} / \mathrm{L}$ & 10 & 10.4 & 104 & $83-125$ & \\
\hline 1,1-Dichloroethane & $\mathrm{ug} / \mathrm{L}$ & 10 & 9.8 & 98 & $79-115$ & \\
\hline 1,1-Dichloroethene & $\mathrm{ug} / \mathrm{L}$ & 10 & 10.2 & 102 & $76-122$ & \\
\hline 1,1-Dichloropropene & $\mathrm{ug} / \mathrm{L}$ & 10 & 10.5 & 105 & 80-119 & \\
\hline 1,2,3-Trichlorobenzene & $\mathrm{ug} / \mathrm{L}$ & 10 & 9.5 & 95 & $70-138$ & \\
\hline 1,2,3-Trichloropropane & $\mathrm{ug} / \mathrm{L}$ & 10 & 10.3 & 103 & $74-129$ & \\
\hline 1,2,4-Trichlorobenzene & $\mathrm{ug} / \mathrm{L}$ & 10 & 9.0 & 90 & $72-131$ & \\
\hline 1,2,4-Trimethylbenzene & $\mathrm{ug} / \mathrm{L}$ & 10 & 9.2 & 92 & $78-123$ & \\
\hline 1,2-Dibromo-3-chloropropane & $\mathrm{ug} / \mathrm{L}$ & 10 & 8.9 & 89 & $61-139$ & \\
\hline 1,2-Dibromoethane (EDB) & $\mathrm{ug} / \mathrm{L}$ & 10 & 10 & 100 & $80-124$ & \\
\hline 1,2-Dichlorobenzene & $\mathrm{ug} / \mathrm{L}$ & 10 & 9.4 & 94 & $82-113$ & \\
\hline 1,2-Dichloroethane & $\mathrm{ug} / \mathrm{L}$ & 10 & 10.9 & 109 & $78-118$ & \\
\hline
\end{tabular}




\section{QUALITY CONTROL DATA}

Project: Kansas Waste Water

Pace Project No.: 6066709

\begin{tabular}{|c|c|c|c|c|c|c|}
\hline LABORATORY CONTROL SAMPLE: & 548227 & & & & & \\
\hline & & Spike & LCS & LCS & $\% \operatorname{Rec}$ & undifiors \\
\hline Parameter & Units & & & & & Quaminers \\
\hline 1,2-Dichloroethene (Total) & ug/L & 20 & 21.5 & 107 & $79-120$ & \\
\hline 1,2-Dichloropropane & $\mathrm{ug} / \mathrm{L}$ & 10 & 10.9 & 109 & 83-117 & \\
\hline 1,3,5-Trimethylbenzene & $\mathrm{ug} / \mathrm{L}$ & 10 & 9.3 & 93 & $79-116$ & \\
\hline 1,3-Dichlorobenzene & ug/L & 10 & 9.1 & 91 & $82-112$ & \\
\hline 1,3-Dichloropropane & $\mathrm{ug} / \mathrm{L}$ & 10 & 10.4 & 104 & $82-121$ & \\
\hline 1,4-Dichlorobenzene & ug/L & 10 & 9.1 & 91 & $81-111$ & \\
\hline 2,2-Dichloropropane & ug/L & 10 & 6.3 & 63 & $55-139$ & \\
\hline 2-Butanone (MEK) & $\mathrm{ug} / \mathrm{L}$ & 25 & 29.6 & 119 & $61-136$ & \\
\hline 2-Chlorotoluene & ug/L & 10 & 9.1 & 91 & $81-115$ & \\
\hline 2-Hexanone & ug/L & 25 & 27.8 & 111 & $65-137$ & \\
\hline 4-Chlorotoluene & $\mathrm{ug} / \mathrm{L}$ & 10 & 9.2 & 92 & $81-111$ & \\
\hline 4-Methyl-2-pentanone (MIBK) & ug/L & 25 & 32.1 & 129 & $65-133$ & \\
\hline Acetone & $\mathrm{ug} / \mathrm{L}$ & 25 & 27.7 & 111 & $58-126$ & \\
\hline Benzene & $\mathrm{ug} / \mathrm{L}$ & 10 & 10.8 & 108 & $81-114$ & \\
\hline Bromobenzene & $\mathrm{ug} / \mathrm{L}$ & 10 & 9.3 & 93 & $84-113$ & \\
\hline Bromochloromethane & ug/L & 10 & 11.2 & 112 & $79-120$ & \\
\hline Bromodichloromethane & ug/L & 10 & 10.0 & 100 & $75-119$ & \\
\hline Bromoform & $\mathrm{ug} / \mathrm{L}$ & 10 & 6.8 & 68 & $66-132$ & \\
\hline Bromomethane & ug/L & 10 & 5.8 & 58 & $58-151$ & \\
\hline Carbon disulfide & $u g / L$ & 10 & 10.9 & 109 & $49-148$ & \\
\hline Carbon tetrachloride & $\mathrm{ug} / \mathrm{L}$ & 10 & 7.4 & 74 & $62-137$ & \\
\hline Chlorobenzene & ug/L & 10 & 9.9 & 99 & $81-113$ & \\
\hline Chloroethane & $\mathrm{ug} / \mathrm{L}$ & 10 & 12.4 & 124 & $65-119$ & L3 \\
\hline Chloroform & $\mathrm{ug} / \mathrm{L}$ & 10 & 10.4 & 104 & $76-118$ & \\
\hline Chloromethane & ug/L & 10 & 9.6 & 96 & $40-132$ & \\
\hline cis-1,2-Dichloroethene & $\mathrm{ug} / \mathrm{L}$ & 10 & 10.8 & 108 & $80-119$ & \\
\hline cis-1,3-Dichloropropene & $\mathrm{ug} / \mathrm{L}$ & 10 & 9.5 & 95 & $75-122$ & \\
\hline Dibromochloromethane & ug/L & 10 & 8.4 & 84 & $72-124$ & \\
\hline Dibromomethane & $\mathrm{ug} / \mathrm{L}$ & 10 & 11.0 & 110 & $79-121$ & \\
\hline Dichlorodifluoromethane & $\mathrm{ug} / \mathrm{L}$ & 10 & 8.1 & 81 & $11-156$ & \\
\hline Ethylbenzene & $\mathrm{ug} / \mathrm{L}$ & 10 & 9.6 & 96 & $82-115$ & \\
\hline Hexachloro-1,3-butadiene & $\mathrm{ug} / \mathrm{L}$ & 10 & 8.3 & 83 & $72-139$ & \\
\hline Isopropylbenzene (Cumene) & $\mathrm{ug} / \mathrm{L}$ & 10 & 8.4 & 84 & $69-103$ & \\
\hline Methyl-tert-butyl ether & $\mathrm{ug} / \mathrm{L}$ & 10 & 9.4 & 94 & $65-113$ & \\
\hline Methylene chloride & ug/L & 10 & 10.0 & 100 & $76-124$ & \\
\hline n-Butylbenzene & $u g / L$ & 10 & 9.1 & 91 & $77-121$ & \\
\hline n-Propylbenzene & $\mathrm{ug} / \mathrm{L}$ & 10 & 8.9 & 89 & $79-116$ & \\
\hline Naphthalene & ug/L & 10 & 10.6 & 106 & $66-132$ & \\
\hline p-Isopropyltoluene & ug/L & 10 & 8.8 & 88 & $77-114$ & \\
\hline sec-Butylbenzene & ug/L & 10 & 9.1 & 91 & $80-119$ & \\
\hline Styrene & ug/L & 10 & 10.1 & 101 & 81-115 & \\
\hline tert-Butylbenzene & ug/L & 10 & 9.2 & 92 & $77-121$ & \\
\hline Tetrachloroethene & $\mathrm{ug} / \mathrm{L}$ & 10 & 9.2 & 92 & $73-122$ & \\
\hline Toluene & ug/L & 10 & 10.6 & 106 & $82-114$ & \\
\hline trans-1,2-Dichloroethene & $\mathrm{ug} / \mathrm{L}$ & 10 & 10.7 & 107 & $75-122$ & \\
\hline trans-1,3-Dichloropropene & $\mathrm{ug} / \mathrm{L}$ & 10 & 6.5 & 65 & $66-114$ & L2 \\
\hline Trichloroethene & $\mathrm{ug} / \mathrm{L}$ & 10 & 10.6 & 106 & $78-119$ & \\
\hline Trichlorofluoromethane & $\mathrm{ug} / \mathrm{L}$ & 10 & 9.7 & 97 & $71-120$ & \\
\hline
\end{tabular}

This report shall not be reproduced, except in full, 


\section{QUALITY CONTROL DATA}

$\begin{array}{ll}\text { Project: } & \text { Kansas Waste Water } \\ \text { Pace Project No.: } & 6066709\end{array}$

\begin{tabular}{|c|c|c|c|c|c|c|}
\hline \multirow{3}{*}{$\begin{array}{c}\text { LABORATORY CONTROL SAMPLE: } \\
\text { Parameter }\end{array}$} & \multicolumn{6}{|l|}{548227} \\
\hline & & Spike & LCS & LCS & $\% \operatorname{Rec}$ & \\
\hline & Units & Conc. & Result & \% Rec & Limits & Qualifiers \\
\hline Vinyl chloride & ug/L & 10 & 9.2 & 92 & $67-139$ & \\
\hline Xylene (Total) & $\mathrm{ug} / \mathrm{L}$ & 30 & 26.9 & 90 & $81-116$ & \\
\hline 1,2-Dichloroethane-d4 (S) & $\%$ & & & 104 & $81-121$ & \\
\hline 4-Bromofluorobenzene (S) & $\%$ & & & 101 & $87-115$ & \\
\hline Dibromofluoromethane (S) & $\%$ & & & 105 & $87-113$ & \\
\hline Toluene-d8 (S) & $\%$ & & & 105 & $89-111$ & \\
\hline
\end{tabular}




\section{QUALITY CONTROL DATA}

Project: Kansas Waste Water

Pace Project No.: 6066709

\begin{tabular}{llll}
\hline QC Batch: & OEXT/19948 & Analysis Method: & EPA 504.1 \\
QC Batch Method: & EPA 504.1 & Analysis Description: & GCS 504 EDB DBCP
\end{tabular}

Associated Lab Samples: $\quad$ 6066709001, 6066709002, 6066709003, 6066709004, 6066709005

METHOD BLANK: $548830 \quad$ Matrix: Water

Associated Lab Samples: $\quad$ 6066709001, 6066709002, 6066709003, 6066709004, 6066709005

$\frac{\text { Parameter }}{1,2 \text {-Dibromoethane (EDB) }} \frac{\text { Units }}{\mathrm{ug} / \mathrm{L}} \frac{\text { Result }}{\mathrm{ND}} \frac{\begin{array}{c}\text { Blank } \\ \text { Limit }\end{array}}{0.050} \frac{\text { Analyzed }}{10 / 09 / 09 \text { 15:13 }} \stackrel{\text { Qualifiers }}{-}$

\begin{tabular}{|c|c|c|c|c|c|c|c|c|c|c|}
\hline \multirow{2}{*}{\multicolumn{2}{|c|}{ LABORATORY CONTROL SAMPLE \& LCSD: }} & 548831 & \multicolumn{3}{|c|}{548832} & \multirow{3}{*}{$\begin{array}{l}\text { LCSD } \\
\% \operatorname{Rec}\end{array}$} & \multirow{3}{*}{$\begin{array}{l}\% \text { Rec } \\
\text { Limits }\end{array}$} & \multirow{2}{*}{\multicolumn{2}{|c|}{ Max }} & \multirow[b]{3}{*}{ Qualifiers } \\
\hline & & Spike & LCS & LCSD & LCS & & & & & \\
\hline Parameter & Units & Conc. & Result & Result & $\% \operatorname{Rec}$ & & & RPD & RPD & \\
\hline 1,2-Dibromoethane (EDB) & $\mathrm{ug} / \mathrm{L}$ & .25 & 0.29 & 0.30 & 117 & 121 & $70-130$ & 4 & 20 & \\
\hline
\end{tabular}




\section{QUALIFIERS}

Project: $\quad$ Kansas Waste Water

Pace Project No.: 6066709

\section{DEFINITIONS}

DF - Dilution Factor, if reported, represents the factor applied to the reported data due to changes in sample preparation, dilution of the sample aliquot, or moisture content.

ND - Not Detected at or above adjusted reporting limit.

$\mathrm{J}$ - Estimated concentration above the adjusted method detection limit and below the adjusted reporting limit.

MDL - Adjusted Method Detection Limit.

$\mathrm{S}$ - Surrogate

1,2-Diphenylhydrazine (8270 listed analyte) decomposes to Azobenzene.

Consistent with EPA guidelines, unrounded data are displayed and have been used to calculate \% recovery and RPD values.

LCS(D) - Laboratory Control Sample (Duplicate)

MS(D) - Matrix Spike (Duplicate)

DUP - Sample Duplicate

RPD - Relative Percent Difference

Pace Analytical is NELAP accredited. Contact your Pace PM for the current list of accredited analytes.

$\mathrm{U}$ - Indicates the compound was analyzed for, but not detected.

\section{BATCH QUALIFIERS}

Batch: MSV/23759

[M5] A matrix spike/matrix spike duplicate was not performed for this batch due to insufficient sample volume.

\section{ANALYTE QUALIFIERS}

L2 Analyte recovery in the laboratory control sample (LCS) was below QC limits. Results for this analyte in associated samples may be biased low.

L3 Analyte recovery in the laboratory control sample (LCS) exceeded QC limits. Analyte presence below reporting limits in associated samples. Results unaffected by high bias.

M0 Matrix spike recovery and/or matrix spike duplicate recovery was outside laboratory control limits. 
October 30, 2009

Mr. Travis Kamler

TCW Construction Inc

141 M Street

Lincoln, NE 68508

RE: Project: Kansas Waste Water

Pace Project No.: 6068053

Dear Mr. Kamler:

Enclosed are the analytical results for sample(s) received by the laboratory on October 20, 2009.

The results relate only to the samples included in this report. Results reported herein conform to the most current NELAC standards, where applicable, unless otherwise narrated in the body of the report.

If you have any questions concerning this report, please feel free to contact me.

Sincerely,

$$
\text { sudy sigoon }
$$

Trudy Gipson

trudy.gipson@pacelabs.com

Project Manager

Enclosures

cc: Mr. David Surgnier 


\section{CERTIFICATIONS}

Project:

Kansas Waste Water

Pace Project No.:

6068053

Kansas Certification IDs

Washington Certification \#: C2069

Utah Certification \#: 9135995665

Texas Certification \#: T104704407-08-TX

Oregon Certification \#: KS200001

Oklahoma Certification \#: 9205/9935

Nevada Certification \#: KS000212008A

Louisiana Certification \#: 03055

Kansas/NELAP Certification \#: E-10116

lowa Certification \#: 118

Illinois Certification \#: 001191

Arkansas Certification \#: 05-008-0

A2LA Certification \#: 2456.01

This report shall not be reproduced, except in full, without the written consent of Pace Analytical Services, Inc. 
SAMPLE SUMMARY

Project: Kansas Waste Water

Pace Project No.: 6068053

\begin{tabular}{|c|c|c|c|c|}
\hline Lab ID & Sample ID & Matrix & Date Collected & Date Received \\
\hline 6068053001 & CNPURGE-W-1019091 & Water & 10/19/09 11:00 & 10/20/09 09:05 \\
\hline 6068053002 & BAPURGE-W-1019092 & Water & 10/19/09 12:28 & 10/20/09 09:05 \\
\hline 6068053003 & HAPURGE-W-1019093 & Water & 10/19/09 13:52 & 10/20/09 09:05 \\
\hline 6068053004 & QCTB-W-1019094 & Water & 10/19/09 17:40 & 10/20/09 09:05 \\
\hline
\end{tabular}


SAMPLE ANALYTE COUNT

Project: Kansas Waste Water

Pace Project No.: 6068053

\begin{tabular}{|c|c|c|c|c|}
\hline Lab ID & Sample ID & Method & Analysts & $\begin{array}{l}\text { Analytes } \\
\text { Reported }\end{array}$ \\
\hline \multirow[t]{3}{*}{6068053001} & CNPURGE-W-1019091 & EPA 300.0 & $\mathrm{RAB}$ & 1 \\
\hline & & EPA 5030B/8260 & AJA & 70 \\
\hline & & EPA 504.1 & NAW & 1 \\
\hline \multirow[t]{3}{*}{6068053002} & BAPURGE-W-1019092 & EPA 300.0 & RAB & 1 \\
\hline & & EPA 5030B/8260 & AJA & 70 \\
\hline & & EPA 504.1 & NAW & 1 \\
\hline \multirow[t]{3}{*}{6068053003} & HAPURGE-W-1019093 & EPA 300.0 & $\mathrm{RAB}$ & 1 \\
\hline & & EPA 5030B/8260 & AJA & 70 \\
\hline & & EPA 504.1 & NAW & 1 \\
\hline 6068053004 & QCTB-W-1019094 & EPA 5030B/8260 & AJA & 70 \\
\hline
\end{tabular}




\section{ANALYTICAL RESULTS}

Project: Kansas Waste Water

Pace Project No.: 6068053

\begin{tabular}{|c|c|c|c|c|c|c|c|c|c|}
\hline Sample & CNPURGE-W-1019091 & Lab ID: & 6068053001 & Collected: $10 / 19$ & $11: 00$ & Received: & 10/20/09 09:05 & Matrix: Water & \\
\hline & Parameters & Results & Units & Report Limit & DF & Prepared & Analyzed & CAS No. & Qual \\
\hline
\end{tabular}

504 GCS EDB and DBCP

1,2-Dibromoethane (EDB)

\section{MSV}

Acetone

Benzene

Bromobenzene

Bromochloromethane

Bromodichloromethane

Bromoform

Bromomethane

2-Butanone (MEK)

n-Butylbenzene

sec-Butylbenzene

tert-Butylbenzene

Carbon disulfide

Carbon tetrachloride

Chlorobenzene

Chloroethane

Chloroform

Chloromethane

2-Chlorotoluene

4-Chlorotoluene

1,2-Dibromo-3-chloropropane

Dibromochloromethane

1,2-Dibromoethane (EDB)

Dibromomethane

1,2-Dichlorobenzene

1,3-Dichlorobenzene

1,4-Dichlorobenzene

Dichlorodifluoromethane

1,1-Dichloroethane

1,2-Dichloroethane

1,2-Dichloroethene (Total)

1,1-Dichloroethene

cis-1,2-Dichloroethene

trans-1,2-Dichloroethene

1,2-Dichloropropane

1,3-Dichloropropane

2,2-Dichloropropane

1,1-Dichloropropene

cis-1,3-Dichloropropene

trans-1,3-Dichloropropene

Ethylbenzene

Hexachloro-1,3-butadiene

2-Hexanone

Isopropylbenzene (Cumene)

p-Isopropyltoluene

Date: 10/30/2009 10:54 AM
Analytical Method: EPA 504.1 Preparation Method: EPA 504.1

$$
\begin{array}{lllllllll}
\text { ND ug/L } & 0.028 & 1 & 10 / 27 / 09 & 00: 00 & 10 / 27 / 09 & 17: 43 & 106-93-4
\end{array}
$$

Analytical Method: EPA 5030B/8260

\begin{tabular}{|c|c|}
\hline ND ug/L & 10.0 \\
\hline ND ug/L & 1.0 \\
\hline ND ug/L & 1.0 \\
\hline ND ug/L & 1.0 \\
\hline ND ug/L & 1.0 \\
\hline ND ug/L & 1.0 \\
\hline ND ug/L & 1.0 \\
\hline ND ug/L & 10.0 \\
\hline ND ug/L & 1.0 \\
\hline ND ug/L & 1.0 \\
\hline ND ug/L & 1.0 \\
\hline ND ug/L & 5.0 \\
\hline $2.3 \mathrm{ug} / \mathrm{L}$ & 1.0 \\
\hline ND ug/L & 1.0 \\
\hline ND ug/L & 1.0 \\
\hline ND ug/L & 1.0 \\
\hline ND ug/L & 1.0 \\
\hline ND ug/L & 1.0 \\
\hline ND ug/L & 1.0 \\
\hline ND ug/L & 2.5 \\
\hline ND ug/L & 1.0 \\
\hline ND ug/L & 1.0 \\
\hline ND ug/L & 1.0 \\
\hline ND ug/L & 1.0 \\
\hline ND ug/L & 1.0 \\
\hline ND ug/L & 1.0 \\
\hline ND ug/L & 1.0 \\
\hline ND ug/L & 1.0 \\
\hline ND ug/L & 1.0 \\
\hline ND ug/L & 1.0 \\
\hline ND ug/L & 1.0 \\
\hline ND ug/L & 1.0 \\
\hline ND ug/L & 1.0 \\
\hline ND ug/L & 1.0 \\
\hline ND ug/L & 1.0 \\
\hline ND ug/L & 1.0 \\
\hline ND ug/L & 1.0 \\
\hline ND ug/L & 1.0 \\
\hline ND ug/L & 1.0 \\
\hline ND ug/L & 1.0 \\
\hline ND ug/L & 1.0 \\
\hline ND ug/L & 10.0 \\
\hline ND ug/L & 1.0 \\
\hline ND ug/L & 1.0 \\
\hline
\end{tabular}

10/24/09 19:10 67-64-1

10/24/09 19:10 71-43-2

10/24/09 19:10 108-86-1

10/24/09 19:10 74-97-5

10/24/09 19:10 75-27-4

10/24/09 19:10 75-25-2

10/24/09 19:10 74-83-9

10/24/09 19:10 78-93-3

10/24/09 19:10 104-51-8

10/24/09 19:10 135-98-8

10/24/09 19:10 98-06-6

10/24/09 19:10 75-15-0

10/24/09 19:10 56-23-5

10/24/09 19:10 108-90-7

10/24/09 19:10 75-00-3

10/24/09 19:10 67-66-3

10/24/09 19:10 74-87-3

10/24/09 19:10 95-49-8

10/24/09 19:10 106-43-4

10/24/09 19:10 96-12-8

10/24/09 19:10 124-48-1

10/24/09 19:10 106-93-4

10/24/09 19:10 74-95-3

10/24/09 19:10 95-50-1

10/24/09 19:10 541-73-1

10/24/09 19:10 106-46-7

10/24/09 19:10 75-71-8

10/24/09 19:10 75-34-3

10/24/09 19:10 107-06-2

10/24/09 19:10 540-59-0

10/24/09 19:10 75-35-4

10/24/09 19:10 156-59-2

10/24/09 19:10 156-60-5

10/24/09 19:10 78-87-5

10/24/09 19:10 142-28-9

10/24/09 19:10 594-20-7

10/24/09 19:10 563-58-6

10/24/09 19:10 10061-01-5

10/24/09 19:10 10061-02-6

10/24/09 19:10 100-41-4

10/24/09 19:10 87-68-3

10/24/09 19:10 591-78-6

10/24/09 19:10 98-82-8

10/24/09 19:10 99-87-6
REPORT OF LABORATORY ANALYSIS

This report shall not be reproduced, except in full,

without the written consent of Pace Analytical Services, Inc. 


\section{ANALYTICAL RESULTS}

Project: Kansas Waste Water

Pace Project No.: 6068053

Sample: CNPURGE-W-1019091 $\quad$ Lab ID: $6068053001 \quad$ Collected: 10/19/09 11:00 Received: 10/20/09 09:05 Matrix: Water

Parameters $\quad$ Results $\longrightarrow$ Units $\longrightarrow$ Report Limit $\stackrel{\text { DF }}{\text { Prepared }}$

8260 MSV

Methylene chloride

4-Methyl-2-pentanone (MIBK)

Methyl-tert-butyl ether

Naphthalene

n-Propylbenzene

Styrene

1,1,1,2-Tetrachloroethane

1,1,2,2-Tetrachloroethane

Tetrachloroethene

Toluene

1,2,3-Trichlorobenzene

1,2,4-Trichlorobenzene

1,1,1-Trichloroethane

1,1,2-Trichloroethane

Trichloroethene

Trichlorofluoromethane

1,2,3-Trichloropropane

1,2,4-Trimethylbenzene

1,3,5-Trimethylbenzene

Vinyl chloride

Xylene (Total)

4-Bromofluorobenzene (S)

Dibromofluoromethane (S)

1,2-Dichloroethane-d4 (S)

Toluene-d8 (S)

Preservation $\mathrm{pH}$

\subsection{IC Anions}

Nitrate as $\mathrm{N}$
Analytical Method: EPA 5030B/8260

$\begin{array}{crrlll}\text { ND ug/L } & 1.0 & 1 & 10 / 24 / 09 & 19: 10 & 75-09-2 \\ \text { ND ug/L } & 10.0 & 1 & 10 / 24 / 09 & 19: 10 & 108-10-1 \\ \text { ND ug/L } & 1.0 & 1 & 10 / 24 / 09 & 19: 10 & 1634-04-4 \\ \text { ND ug/L } & 10.0 & 1 & 10 / 24 / 09 & 19: 10 & 91-20-3 \\ \text { ND ug/L } & 1.0 & 1 & 10 / 24 / 09 & 19: 10 & 103-65-1 \\ \text { ND ug/L } & 1.0 & 1 & 10 / 24 / 09 & 19: 10 & 100-42-5 \\ \text { ND ug/L } & 1.0 & 1 & 10 / 24 / 09 & 19: 10 & 630-20-6 \\ \text { ND ug/L } & 1.0 & 1 & 10 / 24 / 09 & 19: 10 & 79-34-5 \\ \text { ND ug/L } & 1.0 & 1 & 10 / 24 / 09 & 19: 10 & 127-18-4 \\ \text { ND ug/L } & 1.0 & 1 & 10 / 24 / 09 & 19: 10 & 108-88-3 \\ \text { ND ug/L } & 1.0 & 1 & 10 / 24 / 09 & 19: 10 & 87-61-6 \\ \text { ND ug/L } & 1.0 & 1 & 10 / 24 / 09 & 19: 10 & 120-82-1 \\ \text { ND ug/L } & 1.0 & 1 & 10 / 24 / 09 & 19: 10 & 71-55-6 \\ \text { ND ug/L } & 1.0 & 1 & 10 / 24 / 09 & 19: 10 & 79-00-5 \\ \text { ND ug/L } & 1.0 & 1 & 10 / 24 / 09 & 19: 10 & 79-01-6 \\ \text { ND ug/L } & 1.0 & 1 & 10 / 24 / 09 & 19: 10 & 75-69-4 \\ \text { ND ug/L } & 2.5 & 1 & 10 / 24 / 09 & 19: 10 & 96-18-4 \\ \text { ND ug/L } & 1.0 & 1 & 10 / 24 / 09 & 19: 10 & 95-63-6 \\ \text { ND ug/L } & 1.0 & 1 & 10 / 24 / 09 & 19: 10 & 108-67-8 \\ \text { ND ug/L } & 1.0 & 1 & 10 / 24 / 09 & 19: 10 & 75-01-4 \\ \text { ND ug/L } & 3.0 & 1 & 10 / 24 / 09 & 19: 10 & 1330-20-7 \\ 103 \% & 87-115 & 1 & 10 / 24 / 09 & 19: 10 & 460-00-4 \\ 99 \% & 87-113 & 1 & 10 / 24 / 09 & 19: 10 & 1868-53-7 \\ 101 \% & 81-121 & 1 & 10 / 24 / 09 & 19: 10 & 17060-07-0 \\ 101 \% & 89-111 & 1 & 10 / 24 / 09 & 19: 10 & 2037-26-5 \\ 6.0 & 0.10 & 1 & 10 / 24 / 09 & 19: 10 & \end{array}$

Analytical Method: EPA 300.0

$2.1 \mathrm{mg} / \mathrm{L}$

0.101

10/20/09 18:55 14797-55-8

This report shall not be reproduced, except in full, 


\section{ANALYTICAL RESULTS}

Project: Kansas Waste Water

Pace Project No.: 6068053

\begin{tabular}{|c|c|c|c|c|c|c|c|c|}
\hline \multirow{2}{*}{$\begin{array}{c}\text { Sample: QCTB-W-1019094 } \\
\text { Parameters }\end{array}$} & \multirow{2}{*}{\multicolumn{2}{|c|}{$\begin{array}{lr}\text { Lab ID: } & 6068053004 \\
& \\
\text { Results } & \text { Units }\end{array}$}} & \multicolumn{2}{|c|}{ Collected: 10/19/09 17:40 } & \multirow{2}{*}{$\begin{array}{l}\text { Received: } \\
\text { Prepared }\end{array}$} & \multirow{2}{*}{$\begin{array}{c}\text { 10/20/09 09:05 } \mathrm{N} \\
\text { Analyzed }\end{array}$} & \multirow{2}{*}{$\begin{array}{l}\text { Matrix: Water } \\
\text { CAS No. }\end{array}$} & \multirow[b]{2}{*}{ Qual } \\
\hline & & & Report Limit & DF & & & & \\
\hline 8260 MSV & Analytical & al Method: EPA 5 & $30 \mathrm{~B} / 8260$ & & & & & \\
\hline Acetone & & VD ug/L & 10.0 & 1 & & $10 / 24 / 09$ 19:59 & $67-64-1$ & \\
\hline Benzene & & ND ug/L & 1.0 & 1 & & $10 / 24 / 09$ 19:59 & $71-43-2$ & \\
\hline Bromobenzene & & ND ug/L & 1.0 & 1 & & 10/24/09 19:59 & $108-86-1$ & \\
\hline Bromochloromethane & & ND ug/L & 1.0 & 1 & & $10 / 24 / 0919: 59$ & $74-97-5$ & \\
\hline Bromodichloromethane & & ND ug/L & 1.0 & 1 & & $10 / 24 / 09$ 19:59 & $75-27-4$ & \\
\hline Bromoform & & ND ug/L & 1.0 & 1 & & 10/24/09 19:59 & $75-25-2$ & \\
\hline Bromomethane & & VD ug/L & 1.0 & 1 & & $10 / 24 / 09$ 19:59 & $74-83-9$ & \\
\hline 2-Butanone (MEK) & & ND ug/L & 10.0 & 1 & & $10 / 24 / 09$ 19:59 & $78-93-3$ & \\
\hline n-Butylbenzene & & ND ug/L & 1.0 & 1 & & $10 / 24 / 09$ 19:59 & $104-51-8$ & \\
\hline sec-Butylbenzene & & ND ug/L & 1.0 & 1 & & $10 / 24 / 0919: 59$ & $135-98-8$ & \\
\hline tert-Butylbenzene & & ND ug/L & 1.0 & 1 & & $10 / 24 / 09$ 19:59 & $98-06-6$ & \\
\hline Carbon disulfide & & VD ug/L & 5.0 & 1 & & $10 / 24 / 09$ 19:59 & $75-15-0$ & \\
\hline Carbon tetrachloride & & ND ug/L & 1.0 & 1 & & $10 / 24 / 0919: 59$ & $56-23-5$ & \\
\hline Chlorobenzene & & ND ug/L & 1.0 & 1 & & $10 / 24 / 09$ 19:59 & $108-90-7$ & \\
\hline Chloroethane & & ND ug/L & 1.0 & 1 & & 10/24/09 19:59 & $75-00-3$ & \\
\hline Chloroform & & VD ug/L & 1.0 & 1 & & $10 / 24 / 0919: 59$ & $67-66-3$ & \\
\hline Chloromethane & & VD ug/L & 1.0 & 1 & & $10 / 24 / 09$ 19:59 & $74-87-3$ & \\
\hline 2-Chlorotoluene & & VD ug/L & 1.0 & 1 & & $10 / 24 / 09$ 19:59 & $95-49-8$ & \\
\hline 4-Chlorotoluene & & ND ug/L & 1.0 & 1 & & $10 / 24 / 09$ 19:59 & $106-43-4$ & \\
\hline 1,2-Dibromo-3-chloropropane & & ND ug/L & 2.5 & 1 & & $10 / 24 / 0919: 59$ & $96-12-8$ & \\
\hline Dibromochloromethane & & ND ug/L & 1.0 & 1 & & 10/24/09 19:59 & $124-48-1$ & \\
\hline 1,2-Dibromoethane (EDB) & & ND ug/L & 1.0 & 1 & & 10/24/09 19:59 & $106-93-4$ & \\
\hline Dibromomethane & & VD ug/L & 1.0 & 1 & & $10 / 24 / 09$ 19:59 & $74-95-3$ & \\
\hline 1,2-Dichlorobenzene & & VD ug/L & 1.0 & 1 & & $10 / 24 / 09$ 19:59 & $95-50-1$ & \\
\hline 1,3-Dichlorobenzene & & VD ug/L & 1.0 & 1 & & $10 / 24 / 09$ 19:59 & $541-73-1$ & \\
\hline 1,4-Dichlorobenzene & & ND ug/L & 1.0 & 1 & & $10 / 24 / 0919: 59$ & $106-46-7$ & \\
\hline Dichlorodifluoromethane & & ND ug/L & 1.0 & 1 & & $10 / 24 / 09$ 19:59 & $75-71-8$ & \\
\hline 1,1-Dichloroethane & & VD ug/L & 1.0 & 1 & & $10 / 24 / 09$ 19:59 & $75-34-3$ & \\
\hline 1,2-Dichloroethane & & VD ug/L & 1.0 & 1 & & $10 / 24 / 09$ 19:59 & $107-06-2$ & \\
\hline 1,2-Dichloroethene (Total) & & ND ug/L & 1.0 & 1 & & $10 / 24 / 0919: 59$ & $540-59-0$ & \\
\hline 1,1-Dichloroethene & & VD ug/L & 1.0 & 1 & & $10 / 24 / 09$ 19:59 & $75-35-4$ & \\
\hline cis-1,2-Dichloroethene & & VD ug/L & 1.0 & 1 & & $10 / 24 / 09$ 19:59 & $156-59-2$ & \\
\hline trans-1,2-Dichloroethene & & ND ug/L & 1.0 & 1 & & $10 / 24 / 0919: 59$ & $156-60-5$ & \\
\hline 1,2-Dichloropropane & & VD ug/L & 1.0 & 1 & & $10 / 24 / 09$ 19:59 & $78-87-5$ & \\
\hline 1,3-Dichloropropane & & ND ug/L & 1.0 & 1 & & $10 / 24 / 09$ 19:59 & $142-28-9$ & \\
\hline 2,2-Dichloropropane & & VD ug/L & 1.0 & 1 & & $10 / 24 / 09$ 19:59 & $594-20-7$ & \\
\hline 1,1-Dichloropropene & & ND ug/L & 1.0 & 1 & & 10/24/09 19:59 & $563-58-6$ & \\
\hline cis-1,3-Dichloropropene & & ND ug/L & 1.0 & 1 & & $10 / 24 / 0919: 59$ & $10061-01-5$ & \\
\hline trans-1,3-Dichloropropene & & VD ug/L & 1.0 & 1 & & $10 / 24 / 09$ 19:59 & $10061-02-6$ & \\
\hline Ethylbenzene & & ND ug/L & 1.0 & 1 & & 10/24/09 19:59 & $100-41-4$ & \\
\hline Hexachloro-1,3-butadiene & & VD ug/L & 1.0 & 1 & & $10 / 24 / 09$ 19:59 & $87-68-3$ & \\
\hline 2-Hexanone & & ND ug/L & 10.0 & 1 & & $10 / 24 / 0919: 59$ & $591-78-6$ & \\
\hline Isopropylbenzene (Cumene) & & ND ug/L & 1.0 & 1 & & $10 / 24 / 09$ 19:59 & $98-82-8$ & \\
\hline p-Isopropyltoluene & & ND ug/L & 1.0 & 1 & & $10 / 24 / 0919: 59$ & $99-87-6$ & \\
\hline Methylene chloride & & ND ug/L & 1.0 & 1 & & $10 / 24 / 0919: 59$ & $75-09-2$ & \\
\hline 4-Methyl-2-pentanone (MIBK) & & ND ug/L & 10.0 & 1 & & $10 / 24 / 09$ 19:59 & $108-10-1$ & \\
\hline Methyl-tert-butyl ether & & VD ug/L & 1.0 & 1 & & $10 / 24 / 0919: 59$ & $1634-04-4$ & \\
\hline
\end{tabular}

This report shall not be reproduced, except in full, without the written consent of Pace Analytical Services, Inc.. 


\section{ANALYTICAL RESULTS}

Project: Kansas Waste Water

Pace Project No.: 6068053

\begin{tabular}{|c|c|c|c|c|c|c|c|}
\hline \multirow{2}{*}{$\begin{array}{c}\text { Sample: QCTB-W-1019094 } \\
\text { Parameters }\end{array}$} & \multirow{2}{*}{\multicolumn{2}{|c|}{ 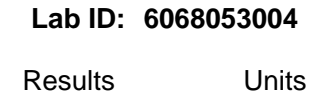 }} & \multirow{2}{*}{$\begin{array}{r}\text { Collected: } \\
\text { Repor }\end{array}$} & 10/19/09 17:40 & \multirow{2}{*}{$\begin{array}{l}\text { Received: } \\
\text { Prepared }\end{array}$} & \multirow{2}{*}{$\begin{array}{r}\text { 10/20/09 09:05 } \\
\text { Analyzed }\end{array}$} & \multirow{2}{*}{$\begin{array}{l}\text { Matrix: Water } \\
\text { CAS No. }\end{array}$} \\
\hline & & & & DF & & & \\
\hline 8260 MSV & Analytical & Method: EPA 5 & $30 \mathrm{~B} / 8260$ & & & & \\
\hline Naphthalene & & D ug/L & 10.0 & 1 & & $10 / 24 / 09$ 19:59 & 9 91-20-3 \\
\hline n-Propylbenzene & & D ug/L & 1.0 & 1 & & 10/24/09 19:59 & 9 103-65-1 \\
\hline Styrene & & D ug/L & 1.0 & 1 & & 10/24/09 19:59 & $9100-42-5$ \\
\hline 1,1,1,2-Tetrachloroethane & & D ug/L & 1.0 & 1 & & 10/24/09 19:59 & $9630-20-6$ \\
\hline 1,1,2,2-Tetrachloroethane & & D ug/L & 1.0 & 1 & & 10/24/09 19:59 & $979-34-5$ \\
\hline Tetrachloroethene & & D ug/L & 1.0 & 1 & & 10/24/09 19:59 & 9 127-18-4 \\
\hline Toluene & & D ug/L & 1.0 & 1 & & 10/24/09 19:59 & $9108-88-3$ \\
\hline 1,2,3-Trichlorobenzene & & D ug/L & 1.0 & 1 & & 10/24/09 19:59 & $987-61-6$ \\
\hline 1,2,4-Trichlorobenzene & & D ug/L & 1.0 & 1 & & 10/24/09 19:59 & $9120-82-1$ \\
\hline 1,1,1-Trichloroethane & & D ug/L & 1.0 & 1 & & 10/24/09 19:59 & $971-55-6$ \\
\hline 1,1,2-Trichloroethane & & D ug/L & 1.0 & 1 & & 10/24/09 19:59 & $979-00-5$ \\
\hline Trichloroethene & & D ug/L & 1.0 & 1 & & $10 / 24 / 0919: 59$ & $979-01-6$ \\
\hline Trichlorofluoromethane & & D ug/L & 1.0 & 1 & & 10/24/09 19:59 & $975-69-4$ \\
\hline 1,2,3-Trichloropropane & & D ug/L & 2.5 & 1 & & 10/24/09 19:59 & $996-18-4$ \\
\hline 1,2,4-Trimethylbenzene & & D ug/L & 1.0 & 1 & & 10/24/09 19:59 & $995-63-6$ \\
\hline 1,3,5-Trimethylbenzene & & D ug/L & 1.0 & 1 & & 10/24/09 19:59 & 9 108-67-8 \\
\hline Vinyl chloride & & D ug/L & 1.0 & 1 & & 10/24/09 19:59 & $975-01-4$ \\
\hline Xylene (Total) & & D ug/L & 3.0 & 1 & & 10/24/09 19:59 & $91330-20-7$ \\
\hline 4-Bromofluorobenzene (S) & 10 & $2 \%$ & $87-115$ & 1 & & 10/24/09 19:59 & $9460-00-4$ \\
\hline Dibromofluoromethane (S) & 9 & $8 \%$ & $87-113$ & 1 & & 10/24/09 19:59 & 9 1868-53-7 \\
\hline 1,2-Dichloroethane-d4 (S) & 10 & $1 \%$ & $81-121$ & 1 & & 10/24/09 19:59 & 9 17060-07-0 \\
\hline Toluene-d8 (S) & 10 & $2 \%$ & $89-111$ & 1 & & 10/24/09 19:59 & $92037-26-5$ \\
\hline Preservation $\mathrm{pH}$ & 6. & & 0.10 & 1 & & 10/24/09 19:59 & \\
\hline
\end{tabular}

This report shall not be reproduced, except in full, 


\section{QUALITY CONTROL DATA}

Project: Kansas Waste Water

Pace Project No.: 6068053

\begin{tabular}{llll}
\hline QC Batch: & WETA/11239 & Analysis Method: & EPA 300.0 \\
QC Batch Method: & EPA 300.0 & Analysis Description: & 300.0 IC Anions
\end{tabular}

Associated Lab Samples: $\quad$ 6068053001, 6068053002, 6068053003

METHOD BLANK: $554827 \quad$ Matrix: Water

Associated Lab Samples: $\quad$ 6068053001, 6068053002, 6068053003

$\frac{\text { Parameter }}{\text { Nitrate as } \mathrm{N}} \frac{\text { Units }}{\mathrm{mg} / \mathrm{L}} \frac{\text { Result }}{\mathrm{ND}} \frac{\begin{array}{c}\text { Blank } \\ \text { Limit }\end{array}}{0.10} \frac{\text { Analyzed }}{10 / 20 / 09 \text { 18:20 }} \frac{\text { Qualifiers }}{-}$

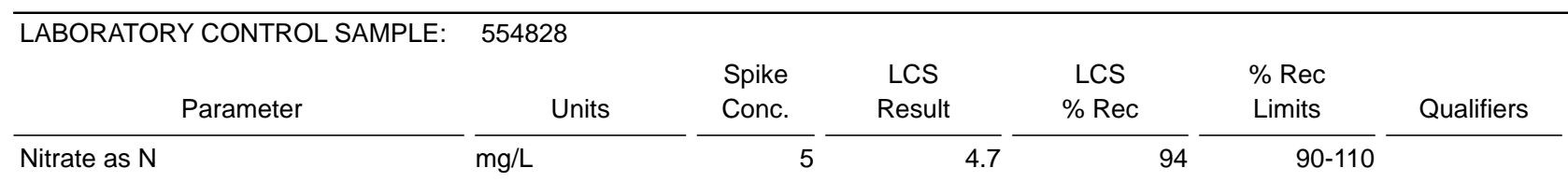

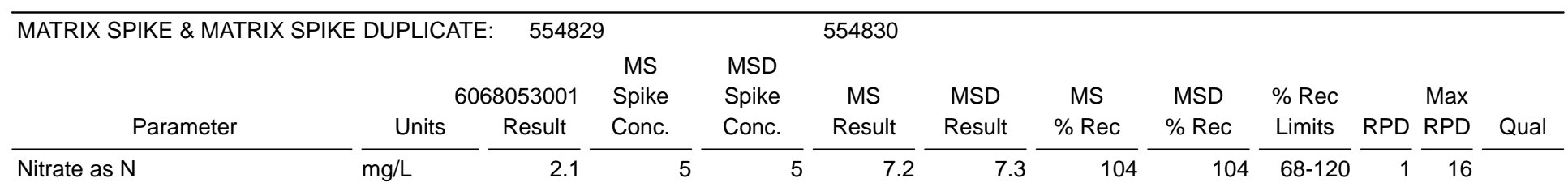




\section{QUALITY CONTROL DATA}

Project: $\quad$ Kansas Waste Water

Pace Project No.: 6068053

\begin{tabular}{llll}
\hline QC Batch: & MSV/24399 & Analysis Method: & EPA 5030B/8260 \\
QC Batch Method: & EPA 5030B/8260 & Analysis Description: & 8260 MSV Water 7 day
\end{tabular}

Associated Lab Samples: $\quad$ 6068053001, 6068053002, 6068053003, 6068053004

METHOD BLANK: $557805 \quad$ Matrix: Water

Associated Lab Samples: 6068053001, 6068053002, 6068053003, 6068053004

\begin{tabular}{|c|c|c|c|c|c|}
\hline Parameter & Units & $\begin{array}{l}\text { Blank } \\
\text { Result }\end{array}$ & $\begin{array}{l}\text { Reporting } \\
\text { Limit }\end{array}$ & Analyzed & Qualifiers \\
\hline 1,1,1,2-Tetrachloroethane & $\mathrm{ug} / \mathrm{L}$ & $\overline{N D}$ & 1.0 & $10 / 24 / 0918: 38$ & \\
\hline 1,1,1-Trichloroethane & $\mathrm{ug} / \mathrm{L}$ & ND & 1.0 & $10 / 24 / 0918: 38$ & \\
\hline 1,1,2,2-Tetrachloroethane & $\mathrm{ug} / \mathrm{L}$ & ND & 1.0 & $10 / 24 / 0918: 38$ & \\
\hline 1,1,2-Trichloroethane & $\mathrm{ug} / \mathrm{L}$ & ND & 1.0 & $10 / 24 / 0918: 38$ & \\
\hline 1,1-Dichloroethane & $\mathrm{ug} / \mathrm{L}$ & ND & 1.0 & $10 / 24 / 0918: 38$ & \\
\hline 1,1-Dichloroethene & $\mathrm{ug} / \mathrm{L}$ & ND & 1.0 & $10 / 24 / 0918: 38$ & \\
\hline 1,1-Dichloropropene & $\mathrm{ug} / \mathrm{L}$ & ND & 1.0 & $10 / 24 / 0918: 38$ & \\
\hline 1,2,3-Trichlorobenzene & $\mathrm{ug} / \mathrm{L}$ & ND & 1.0 & $10 / 24 / 0918: 38$ & \\
\hline 1,2,3-Trichloropropane & $\mathrm{ug} / \mathrm{L}$ & ND & 2.5 & $10 / 24 / 0918: 38$ & \\
\hline 1,2,4-Trichlorobenzene & $\mathrm{ug} / \mathrm{L}$ & ND & 1.0 & $10 / 24 / 0918: 38$ & \\
\hline 1,2,4-Trimethylbenzene & $\mathrm{ug} / \mathrm{L}$ & ND & 1.0 & $10 / 24 / 0918: 38$ & \\
\hline 1,2-Dibromo-3-chloropropane & $\mathrm{ug} / \mathrm{L}$ & ND & 2.5 & $10 / 24 / 0918: 38$ & \\
\hline 1,2-Dibromoethane (EDB) & $\mathrm{ug} / \mathrm{L}$ & ND & 1.0 & $10 / 24 / 0918: 38$ & \\
\hline 1,2-Dichlorobenzene & $\mathrm{ug} / \mathrm{L}$ & ND & 1.0 & $10 / 24 / 0918: 38$ & \\
\hline 1,2-Dichloroethane & $\mathrm{ug} / \mathrm{L}$ & ND & 1.0 & $10 / 24 / 0918: 38$ & \\
\hline 1,2-Dichloroethene (Total) & $\mathrm{ug} / \mathrm{L}$ & ND & 1.0 & $10 / 24 / 0918: 38$ & \\
\hline 1,2-Dichloropropane & $\mathrm{ug} / \mathrm{L}$ & ND & 1.0 & $10 / 24 / 0918: 38$ & \\
\hline 1,3,5-Trimethylbenzene & $\mathrm{ug} / \mathrm{L}$ & ND & 1.0 & $10 / 24 / 0918: 38$ & \\
\hline 1,3-Dichlorobenzene & $\mathrm{ug} / \mathrm{L}$ & ND & 1.0 & $10 / 24 / 0918: 38$ & \\
\hline 1,3-Dichloropropane & $\mathrm{ug} / \mathrm{L}$ & ND & 1.0 & $10 / 24 / 0918: 38$ & \\
\hline 1,4-Dichlorobenzene & $\mathrm{ug} / \mathrm{L}$ & ND & 1.0 & $10 / 24 / 0918: 38$ & \\
\hline 2,2-Dichloropropane & $\mathrm{ug} / \mathrm{L}$ & ND & 1.0 & $10 / 24 / 0918: 38$ & \\
\hline 2-Butanone (MEK) & $\mathrm{ug} / \mathrm{L}$ & ND & 10.0 & $10 / 24 / 0918: 38$ & \\
\hline 2-Chlorotoluene & $\mathrm{ug} / \mathrm{L}$ & ND & 1.0 & $10 / 24 / 0918: 38$ & \\
\hline 2-Hexanone & $\mathrm{ug} / \mathrm{L}$ & ND & 10.0 & $10 / 24 / 0918: 38$ & \\
\hline 4-Chlorotoluene & $\mathrm{ug} / \mathrm{L}$ & ND & 1.0 & $10 / 24 / 0918: 38$ & \\
\hline 4-Methyl-2-pentanone (MIBK) & $\mathrm{ug} / \mathrm{L}$ & ND & 10.0 & $10 / 24 / 0918: 38$ & \\
\hline Acetone & $\mathrm{ug} / \mathrm{L}$ & ND & 10.0 & $10 / 24 / 0918: 38$ & \\
\hline Benzene & ug/L & ND & 1.0 & $10 / 24 / 0918: 38$ & \\
\hline Bromobenzene & $\mathrm{ug} / \mathrm{L}$ & ND & 1.0 & $10 / 24 / 0918: 38$ & \\
\hline Bromochloromethane & $\mathrm{ug} / \mathrm{L}$ & ND & 1.0 & $10 / 24 / 0918: 38$ & \\
\hline Bromodichloromethane & ug/L & ND & 1.0 & $10 / 24 / 0918: 38$ & \\
\hline Bromoform & $\mathrm{ug} / \mathrm{L}$ & ND & 1.0 & $10 / 24 / 0918: 38$ & \\
\hline Bromomethane & $\mathrm{ug} / \mathrm{L}$ & ND & 1.0 & $10 / 24 / 0918: 38$ & \\
\hline Carbon disulfide & $\mathrm{ug} / \mathrm{L}$ & ND & 5.0 & $10 / 24 / 0918: 38$ & \\
\hline Carbon tetrachloride & $\mathrm{ug} / \mathrm{L}$ & ND & 1.0 & $10 / 24 / 0918: 38$ & \\
\hline Chlorobenzene & $\mathrm{ug} / \mathrm{L}$ & ND & 1.0 & $10 / 24 / 0918: 38$ & \\
\hline Chloroethane & $\mathrm{ug} / \mathrm{L}$ & ND & 1.0 & $10 / 24 / 0918: 38$ & \\
\hline Chloroform & $\mathrm{ug} / \mathrm{L}$ & ND & 1.0 & $10 / 24 / 0918: 38$ & \\
\hline Chloromethane & $\mathrm{ug} / \mathrm{L}$ & ND & 1.0 & $10 / 24 / 0918: 38$ & \\
\hline cis-1,2-Dichloroethene & $\mathrm{ug} / \mathrm{L}$ & ND & 1.0 & $10 / 24 / 0918: 38$ & \\
\hline cis-1,3-Dichloropropene & $\mathrm{ug} / \mathrm{L}$ & ND & 1.0 & $10 / 24 / 0918: 38$ & \\
\hline Dibromochloromethane & $\mathrm{ug} / \mathrm{L}$ & ND & 1.0 & $10 / 24 / 0918: 38$ & \\
\hline
\end{tabular}




\section{QUALITY CONTROL DATA}

Project: Kansas Waste Water

Pace Project No.: 6068053

\begin{tabular}{|c|c|c|c|c|c|}
\hline METHOD BLANK: 557805 & & Matrix: & Nater & & \\
\hline Associated Lab Samples: & 01,60680530 & 53003,6068 & 53004 & & \\
\hline Parameter & Units & $\begin{array}{l}\text { Blank } \\
\text { Result }\end{array}$ & $\begin{array}{l}\text { Reporting } \\
\text { Limit }\end{array}$ & Analyzed & Qualifiers \\
\hline Dibromomethane & $\mathrm{ug} / \mathrm{L}$ & $\overline{N D}$ & 1.0 & $10 / 24 / 0918: 38$ & \\
\hline Dichlorodifluoromethane & $u g / L$ & ND & 1.0 & $10 / 24 / 0918: 38$ & \\
\hline Ethylbenzene & $\mathrm{ug} / \mathrm{L}$ & ND & 1.0 & $10 / 24 / 0918: 38$ & \\
\hline Hexachloro-1,3-butadiene & $\mathrm{ug} / \mathrm{L}$ & ND & 1.0 & $10 / 24 / 0918: 38$ & \\
\hline Isopropylbenzene (Cumene) & $u g / L$ & ND & 1.0 & $10 / 24 / 0918: 38$ & \\
\hline Methyl-tert-butyl ether & $\mathrm{ug} / \mathrm{L}$ & ND & 1.0 & $10 / 24 / 0918: 38$ & \\
\hline Methylene chloride & $\mathrm{ug} / \mathrm{L}$ & ND & 1.0 & $10 / 24 / 0918: 38$ & \\
\hline n-Butylbenzene & $\mathrm{ug} / \mathrm{L}$ & ND & 1.0 & $10 / 24 / 0918: 38$ & \\
\hline n-Propylbenzene & ug/L & ND & 1.0 & $10 / 24 / 0918: 38$ & \\
\hline Naphthalene & $\mathrm{ug} / \mathrm{L}$ & ND & 10.0 & $10 / 24 / 0918: 38$ & \\
\hline p-Isopropyltoluene & $\mathrm{ug} / \mathrm{L}$ & ND & 1.0 & $10 / 24 / 0918: 38$ & \\
\hline sec-Butylbenzene & ug/L & ND & 1.0 & $10 / 24 / 0918: 38$ & \\
\hline Styrene & $\mathrm{ug} / \mathrm{L}$ & ND & 1.0 & $10 / 24 / 0918: 38$ & \\
\hline tert-Butylbenzene & $\mathrm{ug} / \mathrm{L}$ & ND & 1.0 & $10 / 24 / 0918: 38$ & \\
\hline Tetrachloroethene & ug/L & ND & 1.0 & $10 / 24 / 0918: 38$ & \\
\hline Toluene & $\mathrm{ug} / \mathrm{L}$ & ND & 1.0 & $10 / 24 / 0918: 38$ & \\
\hline trans-1,2-Dichloroethene & $\mathrm{ug} / \mathrm{L}$ & ND & 1.0 & $10 / 24 / 0918: 38$ & \\
\hline trans-1,3-Dichloropropene & $u g / L$ & ND & 1.0 & $10 / 24 / 0918: 38$ & \\
\hline Trichloroethene & $\mathrm{ug} / \mathrm{L}$ & ND & 1.0 & $10 / 24 / 0918: 38$ & \\
\hline Trichlorofluoromethane & $\mathrm{ug} / \mathrm{L}$ & ND & 1.0 & $10 / 24 / 0918: 38$ & \\
\hline Vinyl chloride & $u g / L$ & ND & 1.0 & $10 / 24 / 0918: 38$ & \\
\hline Xylene (Total) & $\mathrm{ug} / \mathrm{L}$ & ND & 3.0 & $10 / 24 / 0918: 38$ & \\
\hline 1,2-Dichloroethane-d4 (S) & $\%$ & 99 & $81-121$ & $10 / 24 / 0918: 38$ & \\
\hline 4-Bromofluorobenzene (S) & $\%$ & 101 & 87-115 & $10 / 24 / 0918: 38$ & \\
\hline Dibromofluoromethane (S) & $\%$ & 95 & $87-113$ & $10 / 24 / 0918: 38$ & \\
\hline Toluene-d8 (S) & $\%$ & 102 & $89-111$ & $10 / 24 / 0918: 38$ & \\
\hline
\end{tabular}

\begin{tabular}{|c|c|c|c|c|c|c|}
\hline \multirow{2}{*}{$\begin{array}{c}\text { LABORATORY CONTROL SAMPLE: } \\
\text { Parameter }\end{array}$} & \multicolumn{6}{|l|}{557806} \\
\hline & Units & $\begin{array}{l}\text { Spike } \\
\text { Conc. }\end{array}$ & $\begin{array}{l}\text { LCS } \\
\text { Result }\end{array}$ & $\begin{array}{c}\text { LCS } \\
\% \operatorname{Rec}\end{array}$ & $\begin{array}{l}\% \text { Rec } \\
\text { Limits }\end{array}$ & Qualifiers \\
\hline 1,1,1,2-Tetrachloroethane & $\mathrm{ug} / \mathrm{L}$ & 10 & 10.1 & 101 & $75-121$ & \\
\hline 1,1,1-Trichloroethane & $\mathrm{ug} / \mathrm{L}$ & 10 & 9.6 & 96 & $73-120$ & \\
\hline 1,1,2,2-Tetrachloroethane & $\mathrm{ug} / \mathrm{L}$ & 10 & 10.8 & 108 & $73-128$ & \\
\hline 1,1,2-Trichloroethane & ug/L & 10 & 10.1 & 101 & $83-125$ & \\
\hline 1,1-Dichloroethane & $\mathrm{ug} / \mathrm{L}$ & 10 & 9.7 & 97 & $79-115$ & \\
\hline 1,1-Dichloroethene & $\mathrm{ug} / \mathrm{L}$ & 10 & 9.5 & 95 & $76-122$ & \\
\hline 1,1-Dichloropropene & $\mathrm{ug} / \mathrm{L}$ & 10 & 10.0 & 100 & $80-119$ & \\
\hline 1,2,3-Trichlorobenzene & $\mathrm{ug} / \mathrm{L}$ & 10 & 11.6 & 116 & $70-138$ & \\
\hline 1,2,3-Trichloropropane & $\mathrm{ug} / \mathrm{L}$ & 10 & 11.5 & 115 & $74-129$ & \\
\hline 1,2,4-Trichlorobenzene & $\mathrm{ug} / \mathrm{L}$ & 10 & 10.7 & 107 & $72-131$ & \\
\hline 1,2,4-Trimethylbenzene & ug/L & 10 & 10.0 & 100 & $78-123$ & \\
\hline 1,2-Dibromo-3-chloropropane & $\mathrm{ug} / \mathrm{L}$ & 10 & 11.3 & 113 & $61-139$ & \\
\hline 1,2-Dibromoethane (EDB) & $\mathrm{ug} / \mathrm{L}$ & 10 & 10.2 & 102 & $80-124$ & \\
\hline 1,2-Dichlorobenzene & $\mathrm{ug} / \mathrm{L}$ & 10 & 10 & 100 & $82-113$ & \\
\hline 1,2-Dichloroethane & $\mathrm{ug} / \mathrm{L}$ & 10 & 9.6 & 96 & $78-118$ & \\
\hline
\end{tabular}




\section{QUALITY CONTROL DATA}

Project: Kansas Waste Water

Pace Project No.: 6068053

\begin{tabular}{|c|c|c|c|c|c|c|}
\hline LABORATORY CONTROL SAMPLE: & 557806 & & & & & \\
\hline Parameter & Units & $\begin{array}{l}\text { Spike } \\
\text { Conc. }\end{array}$ & $\begin{array}{l}\text { LCS } \\
\text { Result }\end{array}$ & $\begin{array}{c}\text { LCS } \\
\% \operatorname{Rec}\end{array}$ & $\begin{array}{l}\% \text { Rec } \\
\text { Limits }\end{array}$ & Qualifiers \\
\hline 1,2-Dichloroethene (Total) & $\overline{u g / L}$ & 20 & $\overline{19.4}$ & $\overline{97}$ & $79-120$ & \\
\hline 1,2-Dichloropropane & $\mathrm{ug} / \mathrm{L}$ & 10 & 10.9 & 109 & $83-117$ & \\
\hline 1,3,5-Trimethylbenzene & ug/L & 10 & 8.5 & 85 & $79-116$ & \\
\hline 1,3-Dichlorobenzene & $\mathrm{ug} / \mathrm{L}$ & 10 & 10.1 & 101 & $82-112$ & \\
\hline 1,3-Dichloropropane & $\mathrm{ug} / \mathrm{L}$ & 10 & 10.2 & 102 & $82-121$ & \\
\hline 1,4-Dichlorobenzene & ug/L & 10 & 9.9 & 99 & $81-111$ & \\
\hline 2,2-Dichloropropane & $\mathrm{ug} / \mathrm{L}$ & 10 & 9.2 & 92 & $55-139$ & \\
\hline 2-Butanone (MEK) & $\mathrm{ug} / \mathrm{L}$ & 25 & 26.7 & 107 & $61-136$ & \\
\hline 2-Chlorotoluene & ug/L & 10 & 10.0 & 100 & $81-115$ & \\
\hline 2-Hexanone & $\mathrm{ug} / \mathrm{L}$ & 25 & 25.6 & 102 & $65-137$ & \\
\hline 4-Chlorotoluene & $\mathrm{ug} / \mathrm{L}$ & 10 & 9.9 & 99 & $81-111$ & \\
\hline 4-Methyl-2-pentanone (MIBK) & ug/L & 25 & 22.9 & 92 & $65-133$ & \\
\hline Acetone & $\mathrm{ug} / \mathrm{L}$ & 25 & 28.8 & 115 & $58-126$ & \\
\hline Benzene & $\mathrm{ug} / \mathrm{L}$ & 10 & 9.6 & 96 & $81-114$ & \\
\hline Bromobenzene & $\mathrm{ug} / \mathrm{L}$ & 10 & 10.0 & 100 & $84-113$ & \\
\hline Bromochloromethane & $\mathrm{ug} / \mathrm{L}$ & 10 & 9.3 & 93 & $79-120$ & \\
\hline Bromodichloromethane & $\mathrm{ug} / \mathrm{L}$ & 10 & 9.4 & 94 & $75-119$ & \\
\hline Bromoform & $\mathrm{ug} / \mathrm{L}$ & 10 & 9.7 & 97 & $66-132$ & \\
\hline Bromomethane & $\mathrm{ug} / \mathrm{L}$ & 10 & 13.0 & 130 & $58-151$ & \\
\hline Carbon disulfide & $\mathrm{ug} / \mathrm{L}$ & 10 & 11.1 & 111 & $49-148$ & \\
\hline Carbon tetrachloride & $\mathrm{ug} / \mathrm{L}$ & 10 & 9.8 & 98 & $62-137$ & \\
\hline Chlorobenzene & $\mathrm{ug} / \mathrm{L}$ & 10 & 9.2 & 92 & $81-113$ & \\
\hline Chloroethane & $\mathrm{ug} / \mathrm{L}$ & 10 & 10 & 100 & $65-119$ & \\
\hline Chloroform & $\mathrm{ug} / \mathrm{L}$ & 10 & 9.9 & 99 & $76-118$ & \\
\hline Chloromethane & ug/L & 10 & 10.2 & 102 & $40-132$ & \\
\hline cis-1,2-Dichloroethene & $\mathrm{ug} / \mathrm{L}$ & 10 & 9.4 & 94 & $80-119$ & \\
\hline cis-1,3-Dichloropropene & $\mathrm{ug} / \mathrm{L}$ & 10 & 10.1 & 101 & $75-122$ & \\
\hline Dibromochloromethane & $\mathrm{ug} / \mathrm{L}$ & 10 & 9.5 & 95 & $72-124$ & \\
\hline Dibromomethane & $\mathrm{ug} / \mathrm{L}$ & 10 & 9.8 & 98 & $79-121$ & \\
\hline Dichlorodifluoromethane & $\mathrm{ug} / \mathrm{L}$ & 10 & 10.0 & 100 & $11-156$ & \\
\hline Ethylbenzene & $\mathrm{ug} / \mathrm{L}$ & 10 & 9.2 & 92 & $82-115$ & \\
\hline Hexachloro-1,3-butadiene & $\mathrm{ug} / \mathrm{L}$ & 10 & 11.8 & 118 & $72-139$ & \\
\hline Isopropylbenzene (Cumene) & $\mathrm{ug} / \mathrm{L}$ & 10 & 8.3 & 83 & 69-103 & \\
\hline Methyl-tert-butyl ether & $\mathrm{ug} / \mathrm{L}$ & 10 & 10.4 & 104 & $65-113$ & \\
\hline Methylene chloride & $\mathrm{ug} / \mathrm{L}$ & 10 & 10.6 & 106 & $76-124$ & \\
\hline n-Butylbenzene & $\mathrm{ug} / \mathrm{L}$ & 10 & 10.4 & 104 & $77-121$ & \\
\hline n-Propylbenzene & $\mathrm{ug} / \mathrm{L}$ & 10 & 10.0 & 100 & $79-116$ & \\
\hline Naphthalene & $\mathrm{ug} / \mathrm{L}$ & 10 & 11.2 & 112 & $66-132$ & \\
\hline p-Isopropyltoluene & $\mathrm{ug} / \mathrm{L}$ & 10 & 9.8 & 98 & $77-114$ & \\
\hline sec-Butylbenzene & $\mathrm{ug} / \mathrm{L}$ & 10 & 10.4 & 104 & $80-119$ & \\
\hline Styrene & $\mathrm{ug} / \mathrm{L}$ & 10 & 9.6 & 96 & $81-115$ & \\
\hline tert-Butylbenzene & $\mathrm{ug} / \mathrm{L}$ & 10 & 10.2 & 102 & $77-121$ & \\
\hline Tetrachloroethene & $\mathrm{ug} / \mathrm{L}$ & 10 & 9.1 & 91 & $73-122$ & \\
\hline Toluene & $\mathrm{ug} / \mathrm{L}$ & 10 & 9.5 & 95 & $82-114$ & \\
\hline trans-1,2-Dichloroethene & $\mathrm{ug} / \mathrm{L}$ & 10 & 9.9 & 99 & $75-122$ & \\
\hline trans-1,3-Dichloropropene & $\mathrm{ug} / \mathrm{L}$ & 10 & 9.1 & 91 & $66-114$ & \\
\hline Trichloroethene & $\mathrm{ug} / \mathrm{L}$ & 10 & 10.1 & 101 & $78-119$ & \\
\hline Trichlorofluoromethane & $\mathrm{ug} / \mathrm{L}$ & 10 & 9.7 & 97 & $71-120$ & \\
\hline
\end{tabular}

This report shall not be reproduced, except in full, 


\section{QUALITY CONTROL DATA}

Project: Kansas Waste Water

Pace Project No.: 6068053

\begin{tabular}{|c|c|c|c|c|c|c|}
\hline \multirow{3}{*}{$\begin{array}{c}\text { LABORATORY CONTROL SAMPLE: } \\
\text { Parameter }\end{array}$} & \multicolumn{6}{|l|}{557806} \\
\hline & & Spike & LCS & LCS & $\% \operatorname{Rec}$ & \\
\hline & Units & Conc. & Result & \% Rec & Limits & Qualifiers \\
\hline Vinyl chloride & ug/L & 10 & 11.2 & 112 & $67-139$ & \\
\hline Xylene (Total) & $\mathrm{ug} / \mathrm{L}$ & 30 & 28.3 & 94 & $81-116$ & \\
\hline 1,2-Dichloroethane-d4 (S) & $\%$ & & & 99 & $81-121$ & \\
\hline 4-Bromofluorobenzene (S) & $\%$ & & & 103 & $87-115$ & \\
\hline Dibromofluoromethane (S) & $\%$ & & & 98 & $87-113$ & \\
\hline Toluene-d8 (S) & $\%$ & & & 102 & $89-111$ & \\
\hline
\end{tabular}

This report shall not be reproduced, except in full, without the written consent of Pace Analytical Services, Inc.. 


\section{QUALITY CONTROL DATA}

Project: Kansas Waste Water

Pace Project No.: 6068053

\begin{tabular}{llll}
\hline QC Batch: & OEXT/20399 & Analysis Method: & EPA 504.1 \\
QC Batch Method: & EPA 504.1 & Analysis Description: & GCS 504 EDB DBCP
\end{tabular}

Associated Lab Samples: 6068053001, 6068053002, 6068053003

METHOD BLANK: $558502 \quad$ Matrix: Water

Associated Lab Samples: 6068053001, 6068053002, 6068053003

$\frac{\text { Parameter }}{1,2 \text {-Dibromoethane (EDB) }} \frac{\text { Units }}{\mathrm{ug} / \mathrm{L}} \frac{\text { Result }}{\mathrm{ND}} \frac{\begin{array}{c}\text { Blank } \\ \text { Limit }\end{array}}{0.030} \frac{\text { Analyzed }}{10 / 27 / 0900: 00} \frac{\text { Qualifiers }}{-}$

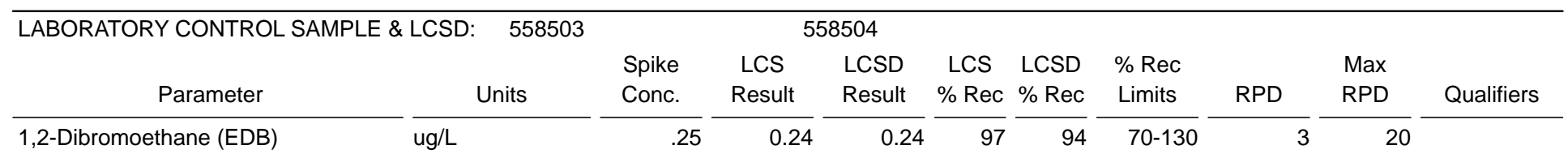




\section{QUALIFIERS}

Project: $\quad$ Kansas Waste Water

Pace Project No.: 6068053

\section{DEFINITIONS}

DF - Dilution Factor, if reported, represents the factor applied to the reported data due to changes in sample preparation, dilution of the sample aliquot, or moisture content.

ND - Not Detected at or above adjusted reporting limit.

$\mathrm{J}$ - Estimated concentration above the adjusted method detection limit and below the adjusted reporting limit.

MDL - Adjusted Method Detection Limit.

$S$ - Surrogate

1,2-Diphenylhydrazine (8270 listed analyte) decomposes to Azobenzene.

Consistent with EPA guidelines, unrounded data are displayed and have been used to calculate \% recovery and RPD values.

LCS(D) - Laboratory Control Sample (Duplicate)

MS(D) - Matrix Spike (Duplicate)

DUP - Sample Duplicate

RPD - Relative Percent Difference

Pace Analytical is NELAP accredited. Contact your Pace PM for the current list of accredited analytes.

$\mathrm{U}$ - Indicates the compound was analyzed for, but not detected.

\section{BATCH QUALIFIERS}

Batch: MSV/24399

[M5] A matrix spike/matrix spike duplicate was not performed for this batch due to insufficient sample volume. 
AGEM $40 \quad \mathrm{~L}$

GENERAL RECEIPT

037934

Office of City Clerk

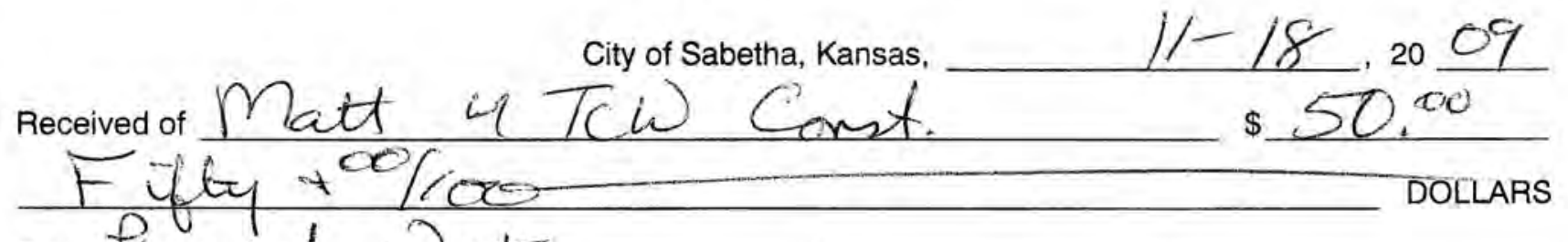

For flu ged Water

Fund

Fund

Fund

City Clerk 


\section{Appendix C:}

Data Summaries for Verification VOCs Analyses by TestAmerica Laboratories, Inc. 


\section{TestAmerica}

THE LEADER IN ENYIRONMENTAL TESTING

TestAmerica Laboratories, Inc.

May 8, 2009

Mr. Clyde Dennis

Argonne National Laboratory

9700 S. Cass Avenue

Building 203, Office B149

Argonne, IL 60439

Re: Laboratory Project No. 21005

Case: CENTRLIA: SDG: 131359

Dear Mr. Dennis:

Enclosed are analytical results for samples that were received by TestAmerica Burlington on April $23^{\text {rd }}$, 2009. Laboratory identification numbers were assigned, and designated as follows:

\begin{tabular}{llll} 
Lab ID & $\begin{array}{l}\text { Client } \\
\text { Sample ID }\end{array}$ & $\begin{array}{l}\text { Sample } \\
\text { Date }\end{array}$ & $\begin{array}{l}\text { Sample } \\
\text { Matrix }\end{array}$ \\
\cline { 2 - 3 } & Received: 04/23/09 ETR No: 131359 & \\
793268 & CNMW02-W-27140 & $04 / 22 / 09$ & WATER \\
793269 & CNPMP8-W-27144 & $04 / 22 / 09$ & WATER \\
793270 & CNQCTB-W-27148 & $04 / 22 / 09$ & WATER \\
793271 & VHBLK01 & $04 / 23 / 09$ & WATER
\end{tabular}

Documentation of the condition of the samples at the time of their receipt and any exception to the laboratory's Sample Acceptance Policy is documented in the Sample Handling section of this submittal. The samples, as received, were not acid preserved. On that basis, the laboratory did provide for the analytical work to be performed within seven days of sample collection.

In order to accommodate field length limitations in processing the data summary forms, the laboratory did, in certain instances, abbreviate the sample identifier. The electronically formatted data provides for the full sample identifier.

\section{SOM01.2 Volatile Organics (Trace Level Water)}

A storage blank was prepared for volatile organics analysis, and stored in association with the storage of the sample. That storage blank, identified as VHBLK01, was carried through the holding period with the samples, and analyzed. 


\section{TestAmerica}

THE LEADER IN ENVIRONMENTAL TESTING

Samples CNMW02-W-27140 and CNPMP8-W-27144 were analyzed at a dilution, based on the results of preliminary screening. An additional, more concentrated analysis was performed on each sample in order to provide a lower reporting limit for those target analytes that were not identified as constituents in the primary analysis. Both sets of results for the analysis of samples CNMW02-W-27140 and CNPMP8-W-27144 are included in this submittal. Each of the analyses associated with the sample set exhibited an acceptable internal standard performance. There was an acceptable recovery of each deuterated monitoring compound (DMC) in the analysis the method blank associated with the analytical work, and in the analysis of the storage blank. The analysis of the samples in this sample set did meet the technical acceptance criteria specific to DMC recoveries, although not all DMC recoveries were within the control range in each analysis. The technical acceptance criteria does provide for the recovery of up to three DMCs to fall outside of the control range in the analysis of field samples. The derived recoveries of 2-butanone- $d_{5}$ and 2-hexanone- $d_{5}$ were elevated in each analysis of samples CNMW02-W-27140 and CNPMP8-W-27144. Matrix spike and matrix spike duplicate analyses were not performed on the samples in this sample set. A trace concentration of acetone was identified in the analysis of one of the method blanks associated with the analytical work (VBLKY8). The concentration level in that analysis was below the established reporting limit, and the acquisition did meet the technical acceptance criteria for an acceptable method blank analysis. The analysis of the storage blank associated with the sample set was free of target analyte contamination. Present in the storage blank and method blank analyses was a nontarget constituent that represented a compound that is related to the DMC formulation. The fact that the presence of this compound is not within the laboratory's control is at issue. The derived results for that compound have been qualified with an " $X$ " qualifier to reflect the source of the contamination. An instrument blank (VIBLKN1) was analyzed following the more concentrated analysis of sample CNMW02-W-27140. There was an acceptable recovery of each deuterated monitoring compound in that analysis. A trace concentration of acetone was identified in the analysis of the instrument blank. The concentration level in that analysis was below the established reporting limit, and the acquisition did meet the technical acceptance criteria for an acceptable instrument blank analysis.

The responses for each target analyte met the relative standard deviation criterion in the initial calibration. The response for each target analyte met the percent difference criterion in the continuing calibration check acquisition. The response for each target analyte met the 50.0 percent difference criterion in the closing calibration check acquisition.

The primary quantitation mass for methylcyclohexane that is specified in the Statement of Work is mass 83 . The laboratory did identify a contribution to mass 83 from 1,2-dichloropropane- $d_{6}$, one of the deuterated monitoring compounds (DMCs). The laboratory did change the primary quantitation mass assignment to mass 55 for the quantification of methylcyclohexane.

Manual integration was employed in deriving certain of the analytical results. The values that have been derived from manual integration are qualified on the quantitation reports. Extracted ion current profiles for each manual integration are included in the data package, and further documented in the Sample Preparation section of this submittal.

Any reference within this report to Severn Trent Laboratories, Inc. or STL, should be understood to refer to TestAmerica Laboratories, Inc. (formerly known as Severn Trent Laboratories, Inc.) The analytical results associated with the samples presented in this test report were generated 


\section{TestAmerica \\ THE LEADER IN ENVIRONMENTAL TESTING}

under a quality system that adheres to requirements specified in the NELAC standard. Release of the data in this test report and any associated electronic deliverables is authorized by the Laboratory Director's designee as verified by the following signature.

If there are any questions regarding this submittal, please contact me at 802 660-1990.

Sincerely,

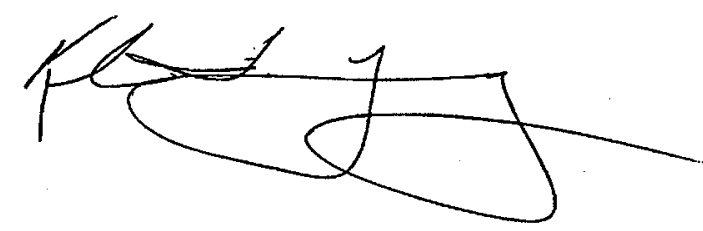

Kirk F. Young

Project Manager

KFY/hsf

Enclosure 


\section{Organic}

U: Compound analyzed but not detected at a concentration above the reporting limit.

$\mathrm{J}: \quad$ Estimated value.

$\mathrm{N}$ : Indicates presumptive evidence of a compound. This flag is used only for tentatively identified compounds (TICs) where the identification of a compound is based on a mass spectral library search.

P: $\quad$ SW-846: The relative percent difference for detected concentrations between two GC columns is greater than $40 \%$. Unless otherwise specified the higher of the two values is reported on the Form 1 .

CLP SOW: Greater than $25 \%$ difference for detected concentrations between two $\mathrm{GC}$ columns. Unless otherwise specified the lower of the two values is reported on the Form I.

C: Pesticide result whose identification has been confirmed by GC/MS.

B: Analyte is found in the sample and the associated method blank. The flag is used for tentatively identified compounds as well as positively identified compounds.

E: Compounds whose concentrations exceed the upper limit of the calibration range of the instrument for that specific analysis.

D: Concentrations identified from analysis of the sample at a secondary dilution.

A: Tentatively identified compound is a suspected aldol condensation product.

$X, Y, Z$ : Laboratory defined flags that may be used alone or combined, as needed. If used, the description of the flag is defined in the project narrative.

\section{Inorganic/Metals}

E: Reported value is estimated due to the presence of interference.

$\mathrm{N}$ : Matrix spike sample recovery is not within control limits.

* Duplicate sample analysis is not within control limits.

B: The result reported is less than the reporting limit but greater than the instrument detection limit.

U: $\quad$ Analyte was analyzed for but not detected above the reporting limit.

\section{Method Codes:}

$\begin{array}{ll}\text { P } & \text { ICP-AES } \\ \text { MS } & \text { ICP-MS } \\ \text { CV } & \text { Cold Vapor AA } \\ \text { AS } & \text { Semi-Automated Spectrophotometric }\end{array}$




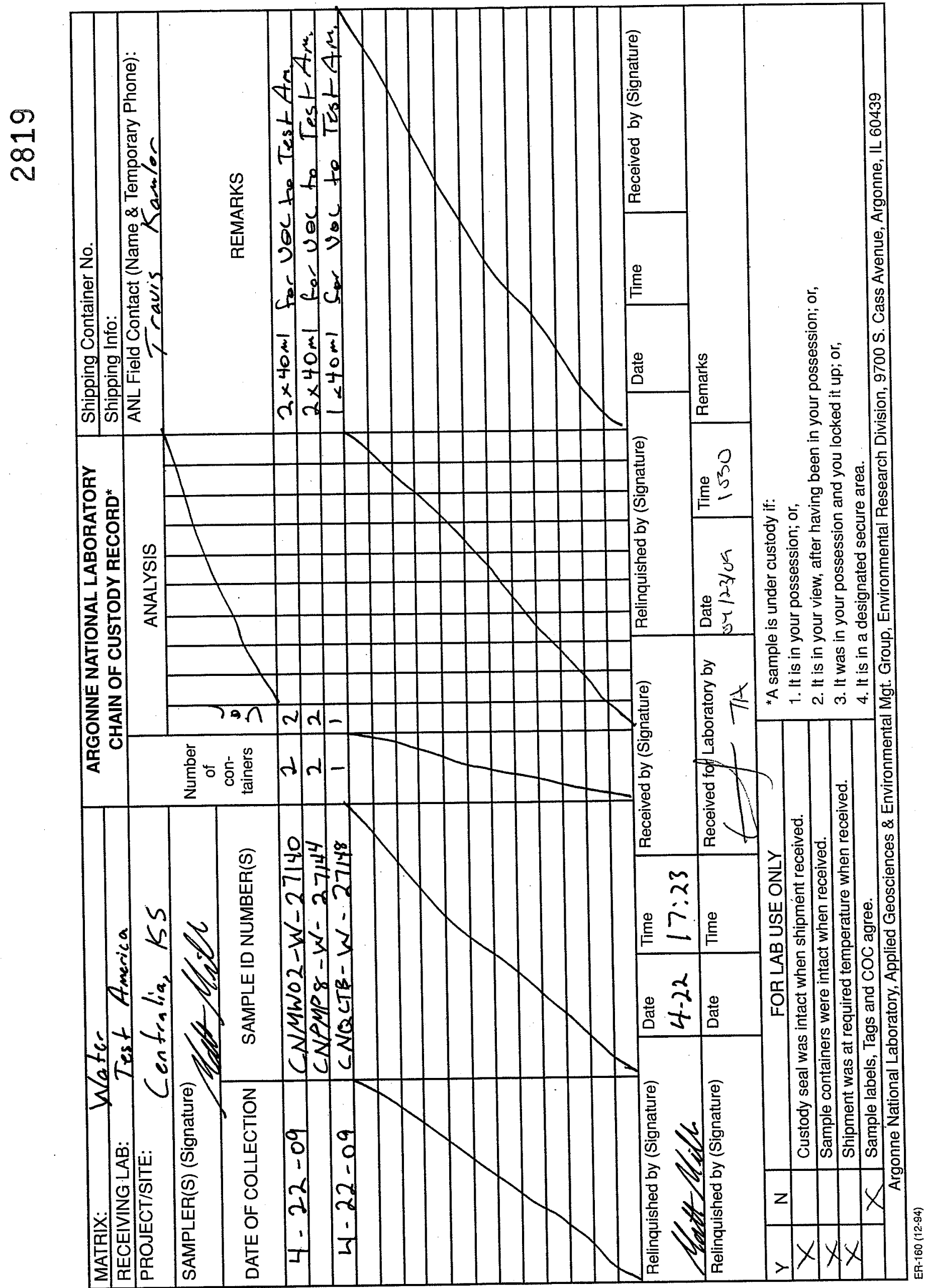




\section{TestAmerica \\ W. \\ THE LEADER IN ENVIRONMENTAL. TESTING}

\section{Sample Data Summary - SOM01.2 Volatiles \\ - Trace}


IA - FORM I VOA-1

VOLATILE ORGANICS ANALYSIS DATA SHEET
EPA SAMPLE NO.

MW02W27140
Lab Name: TESTAMERICA BURLINGTON

Lab Code: STIV

Matrix: (SOIL/SED/WATER) Water

Sample wt/vol: 25.0

$(\mathrm{g} / \mathrm{mL}) \mathrm{mL}$

Level: (TRACE/LOW/MED) TRACE

\% Moisture: not dec.

GC Column: DB-624

ID $: 0.53$

Soil Extract Volume:

Purge Volume: 25.0
Contract: $8 \mathrm{E}-00302$

SDG No.: 131359

\begin{tabular}{|c|c|c|c|}
\hline $\begin{array}{c}\text { CAS NO. } \\
========= \\
75-71-8 \\
74-87-3 \\
75-01-4 \\
74-83-9 \\
75-00-3 \\
75-69-4 \\
75-35-4 \\
76-13-1 \\
67-64-1 \\
75-15-0 \\
79-20-9 \\
75-09-2 \\
156-60-5 \\
1634-04-4 \\
75-34-3 \\
156-59-2 \\
78-93-3 \\
74-97-5 \\
67-66-3 \\
71-55-6 \\
110-82-7 \\
56-23-5 \\
71-43-2 \\
107-06-2\end{array}$ & $\begin{array}{l}\text { COMPOUND } \\
\text { Dichlorodifluoromethane } \\
\text { Chloromethane } \\
\text { Vinyl chloride } \\
\text { Bromomethane } \\
\text { Chloroethane } \\
\text { Trichlorofluoromethane } \\
1,1-\text { Dichloroethene } \\
1,1,2-\text { Trichloro-1, } 2,2-\text { trifluoroethane } \\
\text { Acetone } \\
\text { Carbon disulfide } \\
\text { Methyl acetate } \\
\text { Methylene chloride } \\
\text { trans-1, } 2 \text {-Dichloroethene } \\
\text { Methyl tert-butyl ether } \\
1,1-D i c h l o r o e t h a n e \\
\text { cis-1,2-Dichloroethene } \\
2-\text { Butanone } \\
\text { Bromochloromethane } \\
\text { Chloroform } \\
1,1,1-\text { Trichloroethane } \\
\text { Cyclohexane } \\
\text { Carbon tetrachloride } \\
\text { Benzene } \\
1,2-D i c h l o r o e t h a n e\end{array}$ & 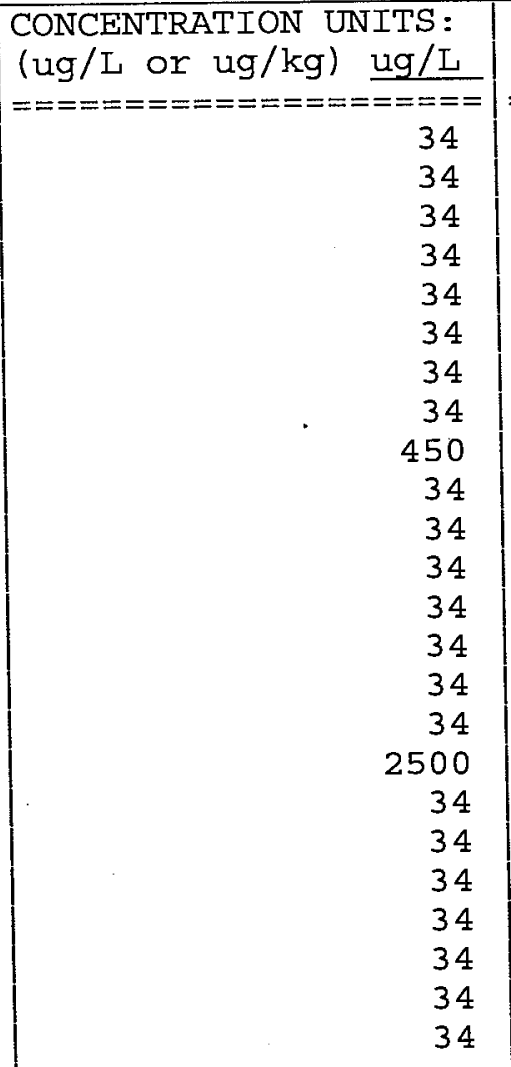 & $\begin{array}{l}====== \\
\mathrm{U} \\
\mathrm{U} \\
\mathrm{U} \\
\mathrm{U} \\
\mathrm{U} \\
\mathrm{U} \\
\mathrm{U} \\
\mathrm{U} \\
\mathrm{U} \\
\mathrm{U} \\
\mathrm{U} \\
\mathrm{U} \\
\mathrm{U} \\
\mathrm{U} \\
\mathrm{U} \\
\mathrm{U} \\
\mathrm{U} \\
\mathrm{U} \\
\mathrm{U} \\
\mathrm{U} \\
\mathrm{U} \\
\mathrm{U}\end{array}$ \\
\hline
\end{tabular}

Report 1,4-Dioxane for Low-Medium VOA analysis only 
1B - FORM I VOA-2

VOLATILE ORGANICS ANALYSIS DATA SHEET
EPA SAMPLE NO.

MW02W2 7140
Lab Name: TESTAMERICA BURLINGTON

Lab Code: STLV Case No.: CENTRLIA Mod. Ref No.:
Contract: $8 \mathrm{E}-00302$

SDG No.: 131359
Matrix: (SOIL/SED/WATER) water

Sample wt/vol: 25.0

$(\mathrm{g} / \mathrm{mL}) \mathrm{mL}$

Level: (TRACE/LOW/MED) TRACE

\% Moisture: not dec.

GC Column: DB-624

$I D: 0.53$

Soil Extract Volume:

Purge Volume: 25.0
Lab Sample ID: 793268

Lab File ID: 793268D2

Date Received: 04/23/2009

Date Analyzed: 04/27/2009

Dilution Factor: 67.7

Soil Aliquot Volume:

(uL)

\begin{tabular}{|c|c|c|c|}
\hline $\begin{array}{l}\text { CAS NO. } \\
========= \\
79-01-6 \\
108-87-2 \\
78-87-5 \\
75-27-4 \\
10061-01-5 \\
108-10-1 \\
108-88-3 \\
10061-02-6 \\
79-00-5 \\
127-18-4 \\
591-78-6 \\
124-48-1 \\
106-93-4 \\
108-90-7 \\
100-41-4 \\
95-47-6 \\
179601-23-1 \\
100-42-5 \\
75-25-2 \\
98-82-8 \\
79-34-5 \\
541-73-1 \\
106-46-7 \\
95-50-1 \\
96-12-8 \\
120-82-1 \\
87-61-6\end{array}$ & 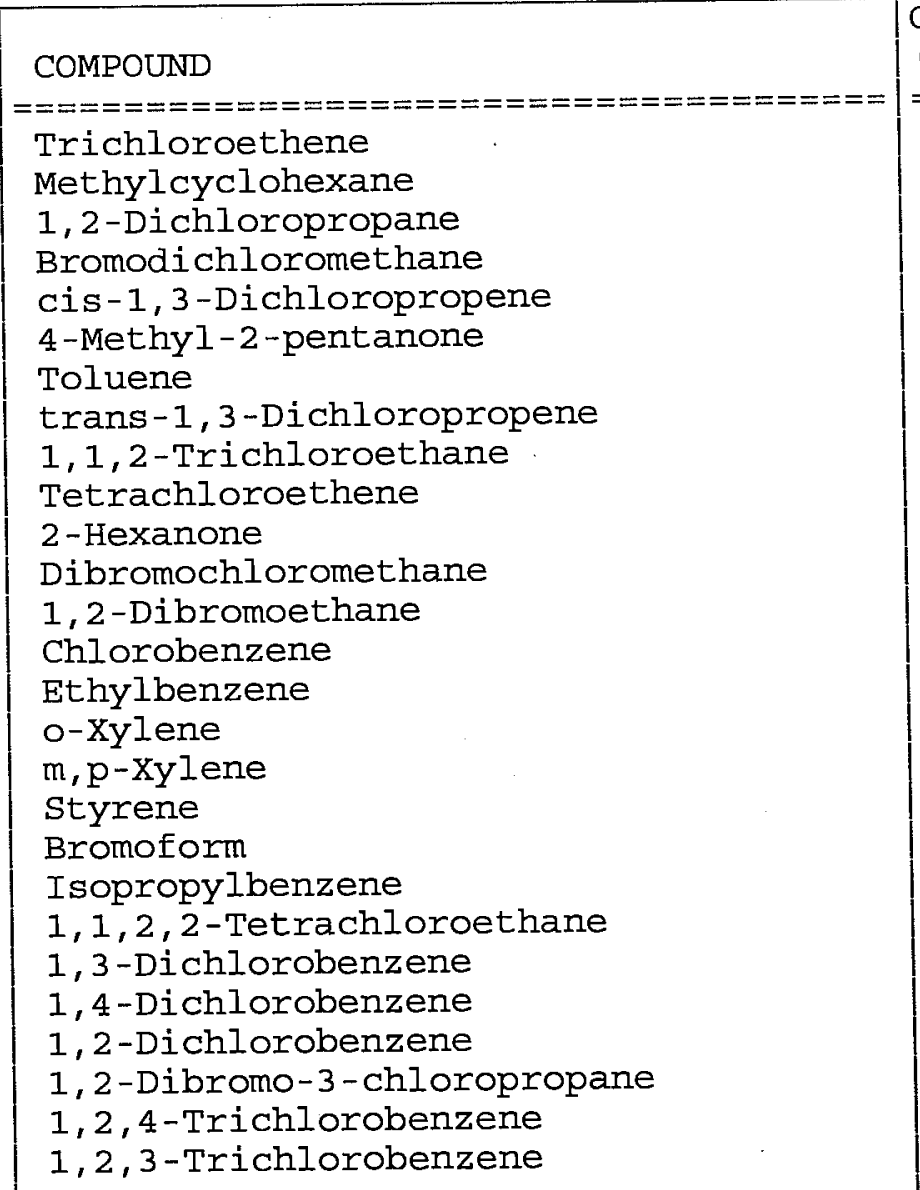 & $\begin{array}{|cr|}\text { CONCENTRATION UNITS : } \\
\text { (ug/L or ug/kg) } \mathrm{ug} / \mathrm{L} \\
================= \\
34 \\
34 \\
34 \\
34 \\
34 \\
340 \\
3600 \\
34 \\
34 \\
34 \\
340 \\
34 \\
34 \\
34 \\
24 \\
34 \\
34 \\
34 \\
34 \\
34 \\
34 \\
34 \\
34 \\
34 \\
34 \\
34 \\
34\end{array}$ & \begin{tabular}{|l}
$======$ \\
$U$ \\
$U$ \\
$U$ \\
$U$ \\
$U$ \\
$U$ \\
$E$ \\
$U$ \\
$U$ \\
$U$ \\
$U$ \\
$U$ \\
$U$ \\
$U$ \\
$J$ \\
$U$ \\
$U$ \\
$U$ \\
$U$ \\
$U$ \\
$U$ \\
$U$ \\
$U$ \\
$U$ \\
$U$ \\
$U$ \\
$U$
\end{tabular} \\
\hline
\end{tabular}


$1 A$ - FORM I VOA-1

VOLATILE ORGANICS ANALYSIS DATA SHEET

Lab Name: TESTAMERICA BURLINGTON

Lab Code: STLV Case No.: CENTRIIA Mod. Ref No.:
Contract : 8E-00302

SDG No.: 131359
Matrix: (SOIL/SED/WATER) Water

Sample wt/vol: 25.0

$(\mathrm{g} / \mathrm{mL}) \mathrm{mL}$

Level: (TRACE/LOW/MED) TRACE

$\%$ Moisture: not dec.

GC Column: DB-624

ID $: 0.53$

Soil Extract Volume:

Purge Volume: 25.0
Lab Sample ID: $793268 D 1$

Lab File ID: $793268 D$

Date Received: 04/23/2009

Date Analyzed: 04/27/2009

Dilution Factor: 677.0

Soil Aliquot Volume:

(uL)

\begin{tabular}{|c|c|c|c|}
\hline $\begin{array}{c}\text { CAS NO. } \\
=========== \\
75-71-8 \\
74-87-3 \\
75-01-4 \\
74-83-9 \\
75-00-3 \\
75-69-4 \\
75-35-4 \\
76-13-1 \\
67-64-1 \\
75-15-0 \\
79-20-9 \\
75-09-2 \\
156-60-5 \\
1634-04-4 \\
75-34-3 \\
156-59-2 \\
78-93-3 \\
74-97-5 \\
67-66-3 \\
71-55-6 \\
110-82-7 \\
56-23-5 \\
71-43-2 \\
107-06-2\end{array}$ & $\begin{array}{l}\text { COMPOUND } \\
=========================== \\
\text { Dichlorodifluoromethane } \\
\text { Chloromethane } \\
\text { Vinyl chloride } \\
\text { Bromomethane } \\
\text { Chloroethane } \\
\text { Trichlorofluoromethane } \\
1,1-D i c h l o r o e t h e n e \\
1,1,2-T r i c h l o r o-1,2,2-t r i f l u o r o e t h a n e \\
\text { Acetone } \\
\text { Carbon disulfide } \\
\text { Methyl acetate } \\
\text { Methylene chloride } \\
\text { trans-1,2-Dichloroethene } \\
\text { Methyl tert-butyl ether } \\
1,1-D i c h l o r o e t h a n e \\
\text { cis-1,2-Dichloroethene } \\
2-\text { Butanone } \\
\text { Bromochloromethane } \\
\text { Chloroform } \\
1,1,1-\text { Trichloroethane } \\
\text { Cyclohexane } \\
\text { Carbon tetrachloride } \\
\text { Benzene } \\
1,2-D i c h l o r o e t h a n e\end{array}$ & \begin{tabular}{|cr} 
CONCENTRATION UNITS : \\
(ug/L Or ug/kg) & ug $/ \mathrm{L}$ \\
$=================$ \\
340 \\
340 \\
340 \\
340 \\
340 \\
340 \\
340 \\
340 \\
3900 \\
340 \\
340 \\
340 \\
340 \\
340 \\
340 \\
340 \\
2600 \\
340 \\
340 \\
340 \\
340 \\
340 \\
340 \\
340
\end{tabular} & $\begin{array}{l}========= \\
\mathrm{U} \\
\mathrm{U} \\
\mathrm{U} \\
\mathrm{U} \\
\mathrm{U} \\
\mathrm{U} \\
\mathrm{U} \\
\mathrm{U} \\
\mathrm{D} \\
\mathrm{U} \\
\mathrm{U} \\
\mathrm{U} \\
\mathrm{U} \\
\mathrm{U} \\
\mathrm{U} \\
\mathrm{U} \\
\mathrm{DJ} \\
\mathrm{U} \\
\mathrm{U} \\
\mathrm{U} \\
\mathrm{U} \\
\mathrm{U} \\
\mathrm{U} \\
\mathrm{U}\end{array}$ \\
\hline
\end{tabular}

Report 1,4-Dioxane for Low-Medium VOA analysis only 
Lab Name: TESTAMERICA BURLINGTON

Contract: $8 \mathrm{E}-00302$

Lab Code: STLV Case No.: CENTRLIA Mod. Ref No.:

SDG No.: 131359

Matrix: (SOIL/SED/WATER) Water

Sample wt/vol: $25.0 \quad(\mathrm{~g} / \mathrm{mL}) \mathrm{mL}$

\section{Level: (TRACE/LOW/MED) TRACE}

$\%$ Moisture: not dec.

GC Column: DB-624

Soil Extract Volume: ID $: 0.53 \quad(\mathrm{~mm})$

(uL)

(mL)

Purge Volume: 25.0
Lab Sample ID: 793268D1

Lab File ID: 793268D

Date Received: 04/23/2009

Date Analyzed: 04/27/2009

Dilution Factor: 677.0

Soil Aliquot Volume:

(uL)

$(\mathrm{mL})$

\begin{tabular}{|c|c|c|c|}
\hline CAS NO. & COMPOUND & $\begin{array}{l}\text { CONCENTRATION UNITS: } \\
(\mathrm{ug} / \mathrm{L} \text { or } \mathrm{ug} / \mathrm{kg}) \mathrm{ug} / \mathrm{L} \\
\end{array}$ & Q \\
\hline$==========$ & 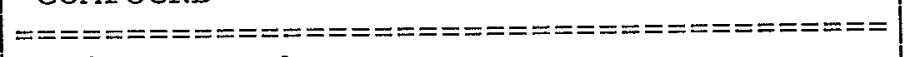 & 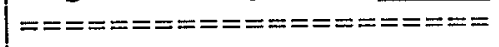 & $=======$ \\
\hline $79-01-6$ & Trichloroethene & 340 & $\mathrm{U}$ \\
\hline $108-87-2$ & Methylcyclohexane & 340 & $\mathrm{U}$ \\
\hline $78-87-5$ & 1,2-Dichloropropane & 340 & $\mathrm{U}$ \\
\hline $75-27-4$ & Bromodichloromethane & 340 & $\mathrm{U}$ \\
\hline $10061-01-5$ & cis-1,3-Dichloropropene & 340 & $\mathrm{U}$ \\
\hline $108-10-1$ & 4 -Methyl-2-pentanone & 3400 & $\mathrm{U}$ \\
\hline $108-88-3$ & Toluene & 9400 & $\mathrm{D}$ \\
\hline $10061-02-6$ & trans-1,3-Dichloropropene & 340 & U \\
\hline $79-00-5$ & $1,1,2$-Trichloroethane & 340 & $\mathrm{U}$ \\
\hline $127-18-4$ & Tetrachloroethene & 340 & $\mathrm{U}$ \\
\hline $591-78-6$ & 2 -Hexanone & 3400 & $\mathrm{U}$ \\
\hline $124-48-1$ & Dibromochloromethane & 340 & $\mathrm{U}$ \\
\hline $106-93-4$ & 1,2-Dibromoethane & 340 & $\mathrm{U}$ \\
\hline $108-90-7$ & Chlorobenzene & 340 & $\mathrm{U}$ \\
\hline $100-41-4$ & Ethylbenzene & 340 & $\mathrm{U}$ \\
\hline $95-47-6$ & o-Xylene & 340 & U \\
\hline $179601-23-1$ & $\mathrm{~m}, \mathrm{p}$-Xylene & 340 & $\mathrm{U}$ \\
\hline $100-42-5$ & Styrene & 340 & $\mathrm{U}$ \\
\hline $75-25-2$ & Bromoform & 340 & $\mathrm{U}$ \\
\hline $98-82-8$ & Isopropylbenzene & 340 & $\mathrm{U}$ \\
\hline $79-34-5$ & $1,1,2,2$-Tetrachloroethane & 340 & $\mathrm{U}$ \\
\hline $541-73-1$ & 1,3 -Dichlorobenzene & 340 & $\mathrm{U}$ \\
\hline $106-46-7$ & 1,4-Dichlorobenzene & 340 & $\mathrm{U}$ \\
\hline $95-50-1$ & 1,2-Dichlorobenzene & 340 & $\mathrm{U}$ \\
\hline $96-12-8$ & 1,2-Dibromo-3-chloropropane & 340 & $\mathrm{U}$ \\
\hline $120-82-1$ & $1,2,4$-Trichlorobenzene & 340 & $\mathrm{U}$ \\
\hline $87-61-6$ & $1,2,3$-Trichlorobenzene & 340 & $\mathrm{U}$ \\
\hline
\end{tabular}


Lab Name: TESTAMERICA BURLINGTON

Lab Code: STLV Case No.: CENTRLIA Mod. Ref No.:
SDG No.: 131359

\section{Matrix: (SOIL/SED/WATER) Water}

Sample wt/vol: 25.0 $(\mathrm{g} / \mathrm{mL}) \mathrm{mL}$

Level : (TRACE/LOW/MED) TRACE

\% Moisture: not dec.

GC Column: DB-624

Soil Extract Volume:

Purge Volume: 25.0
Lab Sample ID: 793269

Lab File ID: 793269

Date Received: 04/23/2009

Date Analyzed: 04/27/2009

Dilution Factor: 1.0

Soil Aliquot Volume:

$(\mathrm{mL})$

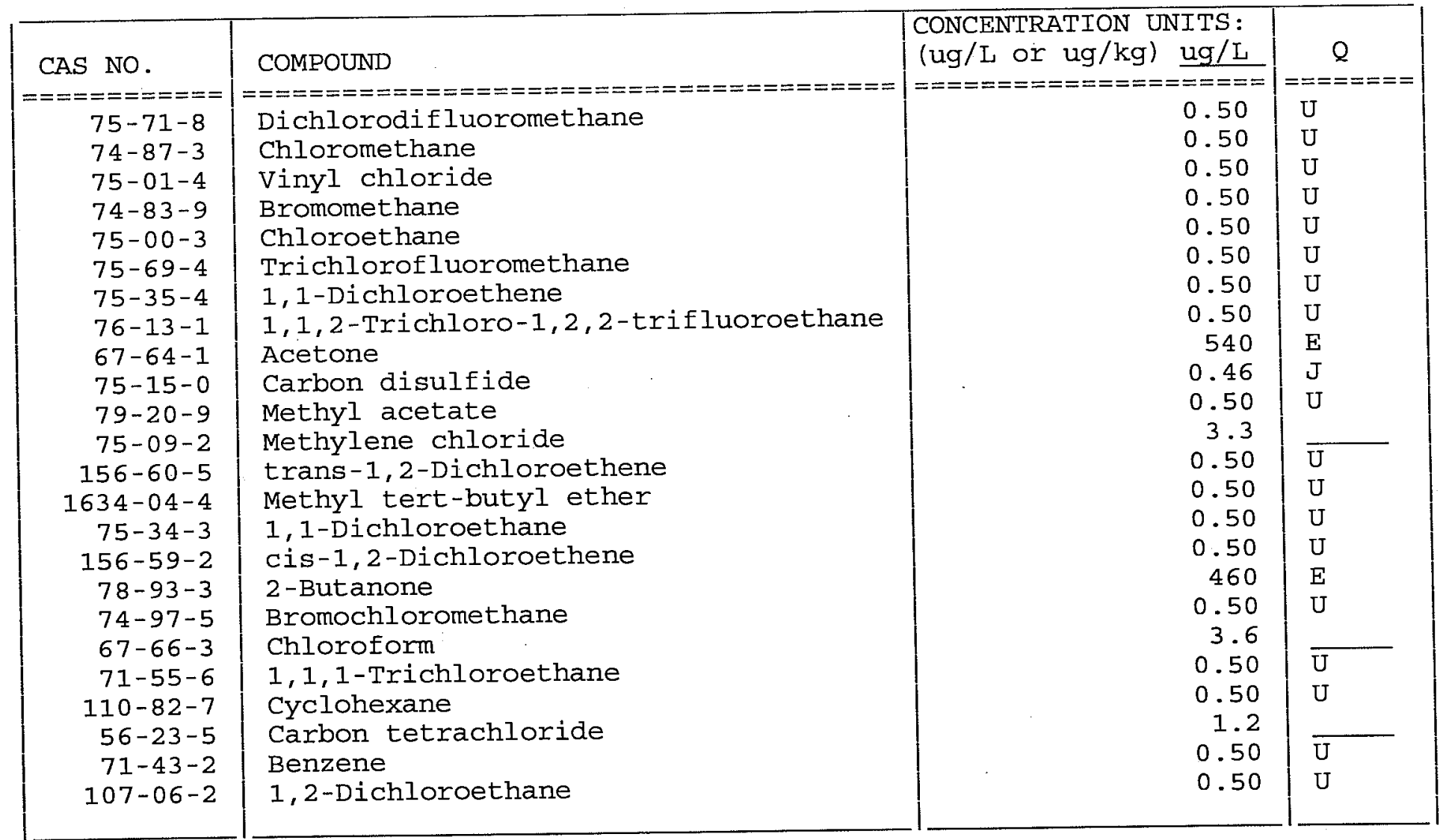

Report 1,4-Dioxane for Low-Medium VOA analysis only 
Lab Name: TESTAMERICA BURLINGTON

Lab Code: STLV Case No.: CENTRLIA Mod. Ref No.:
Contract: 8E-00302
Matrix: (SOIL/SED/WATER) Water

Sample wt/vol: 25.0

$(\mathrm{g} / \mathrm{mL}) \mathrm{mL}$

Level: (TRACE/LOW/MED) TRACE

\% Moisture: not dec.

GC Column: DB-624

Soil Extract Volume:

ID $: 0.53$

$(\mathrm{mm})$

(uL)

(mL)

Purge Volume: 25.0
Lab Sample ID: 793269

Lab File ID: 793269

Date Received: 04/23/2009

Date Analyzed: 04/27/2009

Dilution. Factor: 1.0

Soil Aliquot Volume:

(uL)
SDG No.: 131359

\begin{tabular}{|c|c|c|c|}
\hline CAS NO. & COMPOUND & $\begin{array}{l}\text { CONCENTRATION UNITS: } \\
(\mathrm{ug} / \mathrm{L} \text { or } \mathrm{ug} / \mathrm{kg}) \mathrm{ug} / \mathrm{L}\end{array}$ & Q \\
\hline$==========$ & 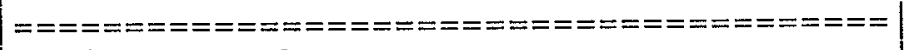 & 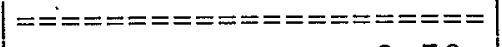 & $=======$ \\
\hline $79-01-6$ & Trichloroethene & 0.50 & $\mathrm{U}$ \\
\hline $108-87-2$ & Methylcyclohexane & 0.50 & $\mathrm{U}$ \\
\hline $78-87-5$ & 1,2-Dichloropropane & 0.50 & $\mathrm{U}$ \\
\hline $75-27-4$ & Bromodichloromethane & 0.50 & $\mathrm{U}$ \\
\hline $10061-01-5$ & cis-1,3-Dichloropropene & 0.50 & $\mathrm{U}$ \\
\hline $108-10-1$ & 4-Methyl-2-pentanone & 5.0 & U \\
\hline $108-88-3$ & Toluene & 0.92 & \\
\hline $10061-02-6$ & trans-1,3-Dichloropropene & 0.50 & $\overline{\mathrm{U}}$ \\
\hline $79-00-5$ & $1,1,2$-Trichloroethane & 0.50 & $\mathrm{U}$ \\
\hline $127-18-4$ & Tetrachloroethene & 0.50 & $\mathrm{U}$ \\
\hline $591-78-6$ & 2 -Hexanone & 5.0 & $\mathrm{U}$ \\
\hline $124-48-1$ & Dibromochloromethane & 0.50 & $\mathrm{U}$ \\
\hline $106-93-4$ & 1,2-Dibromoethane & 0.50 & $\mathrm{U}$ \\
\hline $108-90-7$ & Chlorobenzene & 0.50 & $\mathrm{U}$ \\
\hline $100-41-4$ & Ethylbenzene & 0.50 & $\mathrm{U}$ \\
\hline $95-47-6$ & o-Xylene & 0.50 & $\mathrm{U}$ \\
\hline $179601-23-1$ & $\mathrm{~m}, \mathrm{p}$-Xylene & 0.44 & $\mathrm{~J}$ \\
\hline $100-42-5$ & styrene & 0.50 & $\mathrm{U}$ \\
\hline $75-25-2$ & Bromoform & 0.50 & $\mathrm{U}$ \\
\hline $98-82-8$ & Isopropylbenzene & 0.50 & $\mathrm{U}$ \\
\hline $79-34-5$ & $1,1,2,2$-Tetrachloroethane & 0.50 & $\mathrm{U}$ \\
\hline $541-73-1$ & 1,3-Dichlorobenzene & 0.50 & $\mathrm{U}$ \\
\hline $106-46-7$ & 1,4 -Dichlorobenzene & 0.50 & $\mathrm{U}$ \\
\hline $95-50-1$ & 1,2-Dichlorobenzene & 0.50 & U \\
\hline $96-12-8$ & 1,2-Dibromo-3-chloropropane & 0.50 & U \\
\hline $120-82-1$ & $1,2,4$-Trichlorobenzene & 0.50 & $\mathrm{U}$ \\
\hline $87-61-6$ & $1,2,3$-Trichlorobenzene & 0.50 & $\mathrm{U}$ \\
\hline
\end{tabular}


1A - FORM I VOA-1

VOLATILE ORGANICS ANALYSIS DATA SHEET

Lab Name: TESTAMERICA BURLINGTON

Lab Code: STLV Case No.: CENTRIIA Mod. Ref No.:
Contract: $8 \mathrm{E}-00302$

SDG No.: 131359
Matrix: (SOIL/SED/WATER) Water

Sample wt/vol: 25.0

$(\mathrm{g} / \mathrm{mL}) \mathrm{mL}$

Level: (TRACE/LOW/MED) TRACE

응 Moisture: not dec.

GC Column: DB-624

ID $: 0.53$

Soil Extract Volume:

Purge Volume: 25.0
Lab Sample ID: 793269D1

Lab File ID: $793269 \mathrm{D}$

Date Received: 04/23/2009

Date Analyzed: 04/27/2009

Dilution Factor: 6.3

Soil Aliquot Volume:

(mL)

\begin{tabular}{|c|c|c|c|}
\hline $\begin{array}{c}\text { CAS NO. } \\
========= \\
75-71-8 \\
74-87-3 \\
75-01-4 \\
74-83-9 \\
75-00-3 \\
75-69-4 \\
75-35-4 \\
76-13-1 \\
67-64-1 \\
75-15-0 \\
79-20-9 \\
75-09-2 \\
156-60-5 \\
1634-04-4 \\
75-34-3 \\
156-59-2 \\
78-93-3 \\
74-97-5 \\
67-66-3 \\
71-55-6 \\
110-82-7 \\
56-23-5 \\
71-43-2 \\
107-06-2\end{array}$ & $\begin{array}{l}\text { COMPOUND } \\
\text { Dichlorodifluoromethane } \\
\text { Chloromethane } \\
\text { Vinyl chloride } \\
\text { Bromomethane } \\
\text { Chloroethane } \\
\text { Trichlorofluoromethane } \\
1,1-D i c h l o r o e t h e n e \\
1,1,2-\text { Trichloro-1,2,2-trifluoroethane } \\
\text { Acetone } \\
\text { Carbon disulfide } \\
\text { Methyl acetate } \\
\text { Methylene chloride } \\
\text { trans-1,2-Dichloroethene } \\
\text { Methyl tert-butyl ether } \\
1,1-D i c h l o r o e t h a n e \\
\text { cis-1,2-Dichloroethene } \\
2-\text { Butanone } \\
\text { Bromochloromethane } \\
\text { Chloroform } \\
1,1,1-\text { Trichloroethane } \\
\text { Cyclohexane } \\
\text { Carbon tetrachloride } \\
\text { Benzene } \\
1,2-D i c h l o r o e t h a n e\end{array}$ & \begin{tabular}{|cc} 
CONCENTRATION UNITS : \\
(ug $/ \mathrm{L}$ or ug $/ \mathrm{kg}$ ) \\
ug $/ \mathrm{L}$ \\
$===============$ \\
3.2 \\
3.2 \\
3.2 \\
3.2 \\
3.2 \\
3.2 \\
3.2 \\
3.2 \\
3.2 \\
570 \\
3.2 \\
3.2 \\
2.5 \\
3.2 \\
3.2 \\
3.2 \\
3.2 \\
460 \\
3.2 \\
4.9 \\
3.2 \\
3.2 \\
1.9 \\
3.2 \\
3.2
\end{tabular} & $\begin{array}{l}\text { Q }======= \\
\mathrm{U} \\
\mathrm{U} \\
\mathrm{U} \\
\mathrm{U} \\
\mathrm{U} \\
\mathrm{U} \\
\mathrm{U} \\
\mathrm{U} \\
\mathrm{D} \\
\mathrm{U} \\
\mathrm{U} \\
\mathrm{DJ} \\
\mathrm{U} \\
\mathrm{U} \\
\mathrm{U} \\
\mathrm{U} \\
\mathrm{D} \\
\mathrm{U} \\
\mathrm{D} \\
\mathrm{U} \\
\mathrm{U} \\
\mathrm{DJ} \\
\mathrm{U} \\
\mathrm{U}\end{array}$ \\
\hline
\end{tabular}

Report 1,4-Dioxane for Low-Medium VOA analysis only 
Lab Name: TESTAMERICA BURLINGTON

Lab Code: STLV Case No.: CENTRLIA Mod. Ref No.:
Contract : $8 \mathrm{E}-00302$

SDG No.: 131359
Matrix: (SOIL/SED/WATER) water

Sample wt/vol: 25.0

$(\mathrm{g} / \mathrm{mL}) \mathrm{mL}$

Level: (TRACE/LOW/MED) TRACE

\% Moisture: not dec.

GC Column: DB-624

ID $: 0.53$

Soil Extract Volume:

Purge Volume: 25.0
Lab Sample ID: 793269D1

Lab File ID: $793269 D$

Date Received: 04/23/2009

Date Analyzed: 04/27/2009

Dilution Factor: 6.3

Soil Aliquot Volume:

(mL)

\begin{tabular}{|c|c|c|c|}
\hline \begin{tabular}{|r} 
CAS NO. \\
$==========$ \\
$79-01-6$ \\
$108-87-2$ \\
$78-87-5$ \\
$75-27-4$ \\
$10061-01-5$ \\
$108-10-1$ \\
$108-88-3$ \\
$10061-02-6$ \\
$79-00-5$ \\
$127-18-4$ \\
$591-78-6$ \\
$124-48-1$ \\
$106-93-4$ \\
$108-90-7$ \\
$100-41-4$ \\
$95-47-6$ \\
$179601-23-1$ \\
$100-42-5$ \\
$75-25-2$ \\
$98-82-8$ \\
$79-34-5$ \\
$541-73-1$ \\
$106-46-7$ \\
$95-50-1$ \\
$96-12-8$ \\
$120-82-1$ \\
$87-61-6$
\end{tabular} & 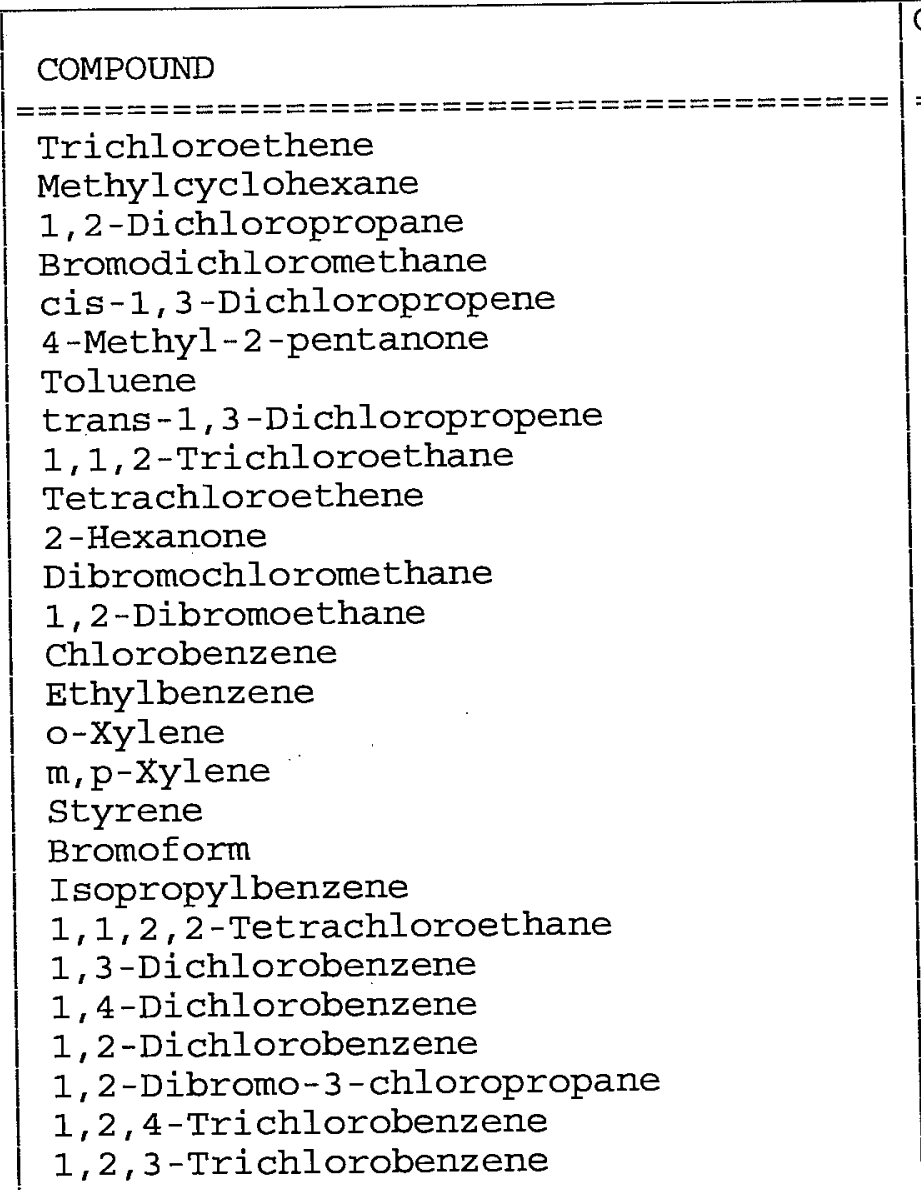 & \begin{tabular}{|c|} 
CONCENTRATION UNITS : \\
$==================$ \\
ug $/ \mathrm{L}$ \\
3.2 \\
3.2 \\
3.2 \\
3.2 \\
3.2 \\
32 \\
3.2 \\
3.2 \\
3.2 \\
3.2 \\
32 \\
3.2 \\
3.2 \\
3.2 \\
3.2 \\
3.2 \\
3.2 \\
3.2 \\
3.2 \\
3.2 \\
3.2 \\
3.2 \\
3.2 \\
3.2 \\
3.2 \\
3.2 \\
3.2
\end{tabular} & $\begin{array}{l}========= \\
U \\
U \\
U \\
U \\
U \\
U \\
U \\
U \\
U \\
U \\
U \\
U \\
U \\
U \\
U \\
U \\
U \\
U \\
U \\
U \\
U \\
U \\
U \\
U \\
U \\
U \\
U\end{array}$ \\
\hline
\end{tabular}


$1 A$ - FORM I VOA-I

VOLATILE ORGANICS ANALYSIS DATA SHEET
EPA SAMPLE NO.

QCTBW2 7148
Lab Name: TESTAMERICA BURLINGTON

Lab Code: STLV Case No.: CENTRLIA Mod. Ref No.:
Contract : $8 \mathrm{E}-00302$

SDG No.: 131359

\section{Matrix: (SOIL/SED/WATER) Water}

Sample wt/vol: 25.0

$(\mathrm{g} / \mathrm{mL}) \mathrm{mL}$

Level: (TRACE/LOW/MED) TRACE

\% Moisture: not dec.

GC Column: DB-624

ID : 0.53

Soil Extract Volume:

Purge Volume: 25.0
Lab Sample ID: 793270

Lab File ID: 793270

Date Received: 04/23/2009

Date Analyzed: 04/27/2009

Dilution Factor: 1.0

Soil Aliquot Volume:

(uL)

\begin{tabular}{|c|c|c|c|}
\hline $\begin{array}{c}\text { CAS NO. } \\
========== \\
75-71-8 \\
74-87-3 \\
75-01-4 \\
74-83-9 \\
75-00-3 \\
75-69-4 \\
75-35-4 \\
76-13-1 \\
67-64-1 \\
75-15-0 \\
79-20-9 \\
75-09-2 \\
156-60-5 \\
1634-04-4 \\
75-34-3 \\
156-59-2 \\
78-93-3 \\
74-97-5 \\
67-66-3 \\
71-55-6 \\
110-82-7 \\
56-23-5 \\
71-43-2 \\
107-06-2\end{array}$ & $\begin{array}{l}\text { COMPOUND } \\
=========================== \\
\text { Dichlorodifluoromethane } \\
\text { Chloromethane } \\
\text { Vinyl chloride } \\
\text { Bromomethane } \\
\text { Chloroethane } \\
\text { Trichlorofluoromethane } \\
\text { 1,1-Dichloroethene } \\
1,1,2-\text { Trichloro-1, } 2,2-\text { trifluoroethane } \\
\text { Acetone } \\
\text { Carbon disulfide } \\
\text { Methyl acetate } \\
\text { Methylene chloride } \\
\text { trans-1,2-Dichloroethene } \\
\text { Methyl tert-butyl ether } \\
1,1-D i c h l o r o e t h a n e \\
\text { cis-1,2-Dichloroethene } \\
2-\text { Butanone } \\
\text { Bromochloromethane } \\
\text { Chloroform } \\
1,1,1-T r i c h l o r o e t h a n e \\
\text { Cyclohexane } \\
\text { Carbon tetrachloride } \\
\text { Benzene } \\
1,2-D i c h l o r o e t h a n e\end{array}$ & 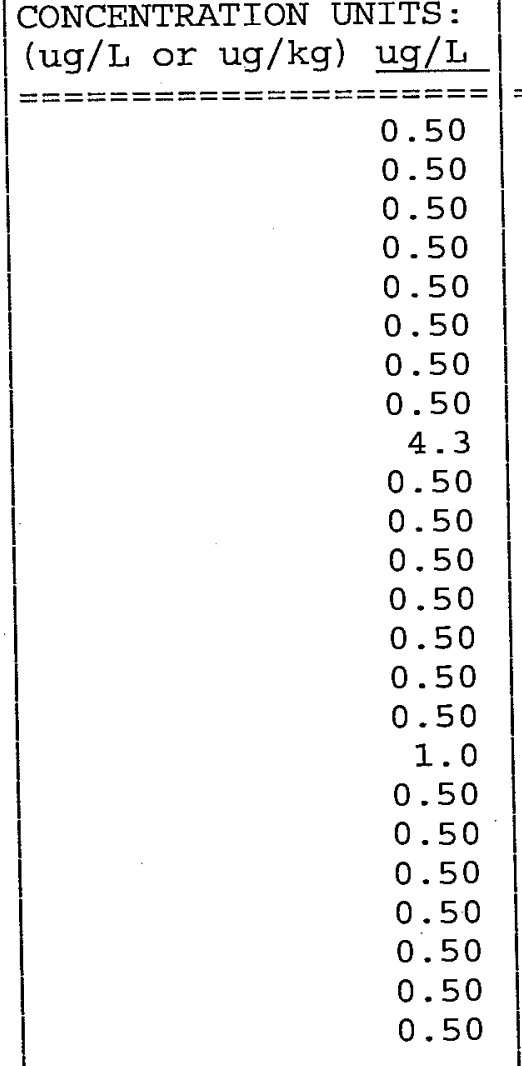 & $\begin{array}{l}========= \\
\mathrm{U} \\
\mathrm{U} \\
\mathrm{U} \\
\mathrm{U} \\
\mathrm{U} \\
\mathrm{U} \\
\mathrm{U} \\
\mathrm{U} \\
\mathrm{J} \\
\mathrm{U} \\
\mathrm{U} \\
\mathrm{U} \\
\mathrm{U} \\
\mathrm{U} \\
\mathrm{U} \\
\mathrm{U} \\
\mathrm{J} \\
\mathrm{U} \\
\mathrm{U} \\
\mathrm{U} \\
\mathrm{U} \\
\mathrm{U} \\
\mathrm{U} \\
\mathrm{U}\end{array}$ \\
\hline
\end{tabular}

Report 1,4-Dioxane for Low-Medium VOA analysis only 
Lab Name: TESTAMERICA BURLINGTON

Lab Code: STLV Case No.: CENTRLIA Mod. Ref No.:
Contract: $8 \mathrm{E}-00302$

SDG No.: 131359
Matrix: (SOIL/SED/WATER) Water

Sample wt/vol: 25.0

$(\mathrm{g} / \mathrm{mL}) \mathrm{mL}$

Level: (TRACE/LOW/MED) TRACE

\% Moisture: not dec.

GC Column: $\mathrm{DB}-624$

Soil Extract Volume:

Purge Volume: 25.0
Lab Sample ID: 793270

Lab File ID: 793270

Date Received: 04/23/2009

Date Analyzed: 04/27/2009

Dilution Factor: 1.0

Soil Aliquot Volume:

$(\mathrm{mL})$

\begin{tabular}{|c|c|c|c|}
\hline CAS NO. & COMPOUND & $\begin{array}{l}\text { CONCENTRATION UNITS: } \\
(\mathrm{ug} / \mathrm{L} \text { or } \mathrm{ug} / \mathrm{kg}) \mathrm{ug} / \mathrm{L}\end{array}$ & Q \\
\hline$===========$ & 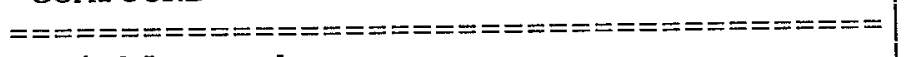 & 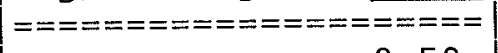 & $=======$ \\
\hline $79-01-6$ & Trichloroethene & 0.50 & $\mathrm{U}$ \\
\hline $108-87-2$ & Methylcyclohexane & 0.50 & $\mathrm{U}$ \\
\hline $78-87-5$ & 1,2-Dichloropropane & 0.50 & $\mathrm{U}$ \\
\hline $75-27-4$ & Bromodichloromethane & 0.50 & $\mathrm{U}$ \\
\hline $10061-01-5$ & cis-1,3-Dichloropropene & 0.50 & $\mathrm{U}$ \\
\hline $108-10-1$ & 4-Methyl-2-pentanone & 5.0 & $\mathrm{U}$ \\
\hline $108-88-3$ & Toluene & 0.50 & $\mathrm{U}$ \\
\hline $10061-02-6$ & trans-1,3-Dichloropropene & 0.50 & $\mathrm{U}$ \\
\hline $79-00-5$ & $1,1,2$-Trichloroethane & 0.50 & $\mathrm{U}$ \\
\hline $127-18-4$ & Tetrachloroethene & 0.50 & $\mathrm{U}$ \\
\hline $591-78-6$ & 2 -Hexanone & 5.0 & U \\
\hline $124-48-1$ & Dibromochloromethane & 0.50 & $\mathrm{U}$ \\
\hline $106-93-4$ & 1,2-Dibromoethane & 0.50 & $\mathrm{U}$ \\
\hline $108-90-7$ & Chlorobenzene. & 0.50 & $\mathrm{U}$ \\
\hline $100-41-4$ & Ethylbenzene & 0.50 & $\mathrm{U}$ \\
\hline $95-47-6$ & o-xylene & 0.50 & $\mathrm{U}$ \\
\hline $179601-23-1$ & $\mathrm{~m}, \mathrm{p}$-Xylene & 0.50 & $\mathrm{U}$ \\
\hline $100-42-5$ & Styrene & 0.50 & $\mathrm{U}$ \\
\hline $75-25-2$ & Bromoform & 0.50 & $\mathrm{U}$ \\
\hline $98-82-8$ & Isopropylbenzene & 0.50 & $\mathrm{U}$ \\
\hline $79-34-5$ & $1,1,2,2$-Tetrachloroethane & 0.50 & $\mathrm{U}$ \\
\hline $541-73-1$ & 1,3-Dichlorobenzene & 0.50 & U \\
\hline $106-46-7$ & 1,4-Dichlorobenzene & 0.50 & $\mathrm{U}$ \\
\hline $95-50-1$ & 1,2-Dichlorobenzene & 0.50 & $\mathrm{U}$ \\
\hline $96-12-8$ & 1,2-Dibromo-3-chloropropane & 0.50 & $\mathrm{U}$ \\
\hline $120-82-1$ & $1,2,4$-Trichlorobenzene & 0.50 & $\mathrm{U}$ \\
\hline $87-61-6$ & $1,2,3$-Trichlorobenzene & 0.50 & $\mathrm{U}$ \\
\hline
\end{tabular}


$1 A$ - FORM I VOA-1

VOLATILE ORGANICS ANALYSIS DATA SHEET
EPA SAMPLE NO.

VHBLK01
Lab Name: TESTAMERICA BURLINGTON

Lab Code: STLV Case No.: CENTRLIA Mod. Ref No.:
Contract: $8 E-00302$

SDG No. : 131359
Matrix: (SOIL/SED/WATER) Water

Sample wt/vol: $25.0 \quad(\mathrm{~g} / \mathrm{mL}) \mathrm{mL}$

Level: (TRACE/LOW/MED) TRACE

\% Moisture: not dec.

GC Column: DB-624

Soil Extract Volume:

Purge Volume: 25.0
Lab Sample ID: 793271

Lab File ID: 793271

Date Received:

Date Analyzed: 04/27/2009

Dilution Factor: 1.0

Soil Aliquot Volume:

(uI)

\begin{tabular}{|c|c|c|c|}
\hline \begin{tabular}{|c|} 
CAS NO. \\
$==========$ \\
$75-71-8$ \\
$74-87-3$ \\
$75-01-4$ \\
$74-83-9$ \\
$75-00-3$ \\
$75-69-4$ \\
$75-35-4$ \\
$76-13-1$ \\
$67-64-1$ \\
$75-15-0$ \\
$79-20-9$ \\
$75-09-2$ \\
$156-60-5$ \\
$1634-04-4$ \\
$75-34-3$ \\
$156-59-2$ \\
$78-93-3$ \\
$74-97-5$ \\
$67-66-3$ \\
$71-55-6$ \\
$110-82-7$ \\
$56-23-5$ \\
$71-43-2$ \\
$107-06-2$
\end{tabular} & $\begin{array}{l}\text { COMPOUND } \\
============================== \\
\text { Dichlorodifluoromethane } \\
\text { Chloromethane } \\
\text { Vinyl chloride } \\
\text { Bromomethane } \\
\text { Chloroethane } \\
\text { Trichlorofluoromethane } \\
\text { 1,1-Dichloroethene } \\
\text { 1,1,2-Trichloro-1,2,2-trifluoroethane } \\
\text { Acetone } \\
\text { Carbon disulfide } \\
\text { Methyl acetate } \\
\text { Methylene chloride } \\
\text { trans-1,2-Dichloroethene } \\
\text { Methyl tert-butyl ether } \\
\text { 1,1-Dichloroethane } \\
\text { Cis-1,2-Dichloroethene } \\
2-\text {-Butanone } \\
\text { Bromochloromethane } \\
\text { Chloroform } \\
\text { 1,1,1-Trichloroethane } \\
\text { Cyclohexane } \\
\text { Carbon tetrachloride } \\
\text { Benzene } \\
1,2-D i c h l o r o e t h a n e\end{array}$ & 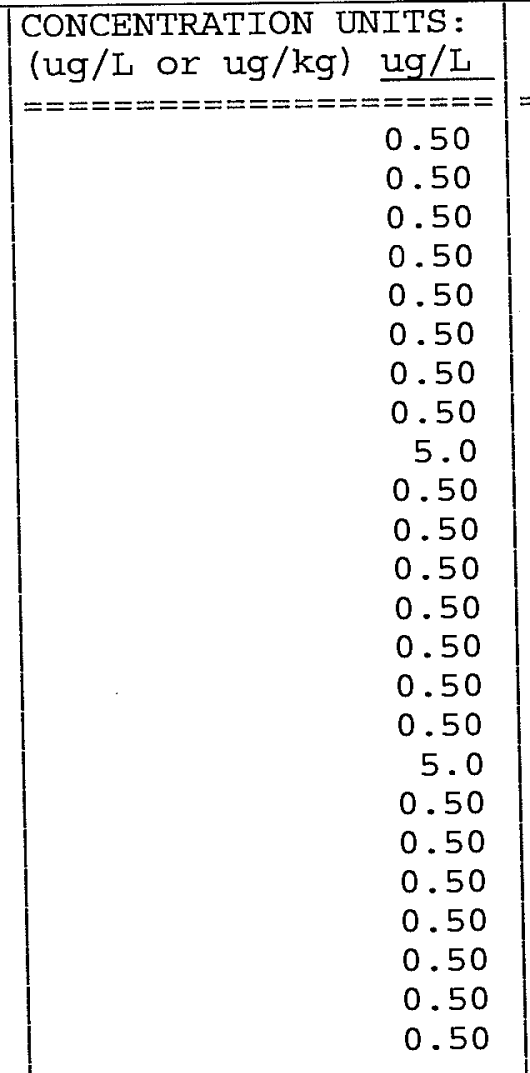 & $\begin{array}{l}\text { Q } \\
========= \\
U \\
U \\
U \\
U \\
U \\
U \\
U \\
U \\
U \\
U \\
U \\
U \\
U \\
U \\
U \\
U \\
U \\
U \\
U \\
U \\
U \\
U \\
U \\
U\end{array}$ \\
\hline
\end{tabular}

Report 1,4-Dioxane for Low-Medium VOA analysis only 
Lab Name: TESTAMERICA BURLINGTON

Lab Code: STLV Case No.: CENTRLIA Mod. Ref No.:
Contract: $8 \mathrm{E}-00302$

SDG No.: 131359
Matrix: (SOIL/SED/WATER) Water

Sample wt/vol: 25.0

$(\mathrm{g} / \mathrm{mL}) \mathrm{mL}$

Level: (TRACE/LOW/MED) TRACE

$\%$ Moisture: not dec.

GC Column: DB-624

ID : 0.53

Soil Extract Volume:

Purge Volume: 25.0
Lab Sample ID: 793271

Lab File ID: 793271

Date Received:

Date Analyzed: 04/27/2009

Dilution Factor: 1.0

Soil Aliquot Volume:

(uL)

\begin{tabular}{|c|c|c|c|}
\hline $\begin{array}{l}\text { CAS NO. } \\
========= \\
79-01-6 \\
108-87-2 \\
78-87-5 \\
75-27-4 \\
10061-01-5 \\
108-10-1 \\
108-88-3 \\
10061-02-6 \\
79-00-5 \\
127-18-4 \\
591-78-6 \\
124-48-1 \\
106-93-4 \\
108-90-7 \\
100-41-4 \\
95-47-6 \\
19601-23-1 \\
100-42-5 \\
75-25-2 \\
98-82-8 \\
79-34-5 \\
541-73-1 \\
106-46-7 \\
95-50-1 \\
96-12-8 \\
120-82-1 \\
87-61-6\end{array}$ & 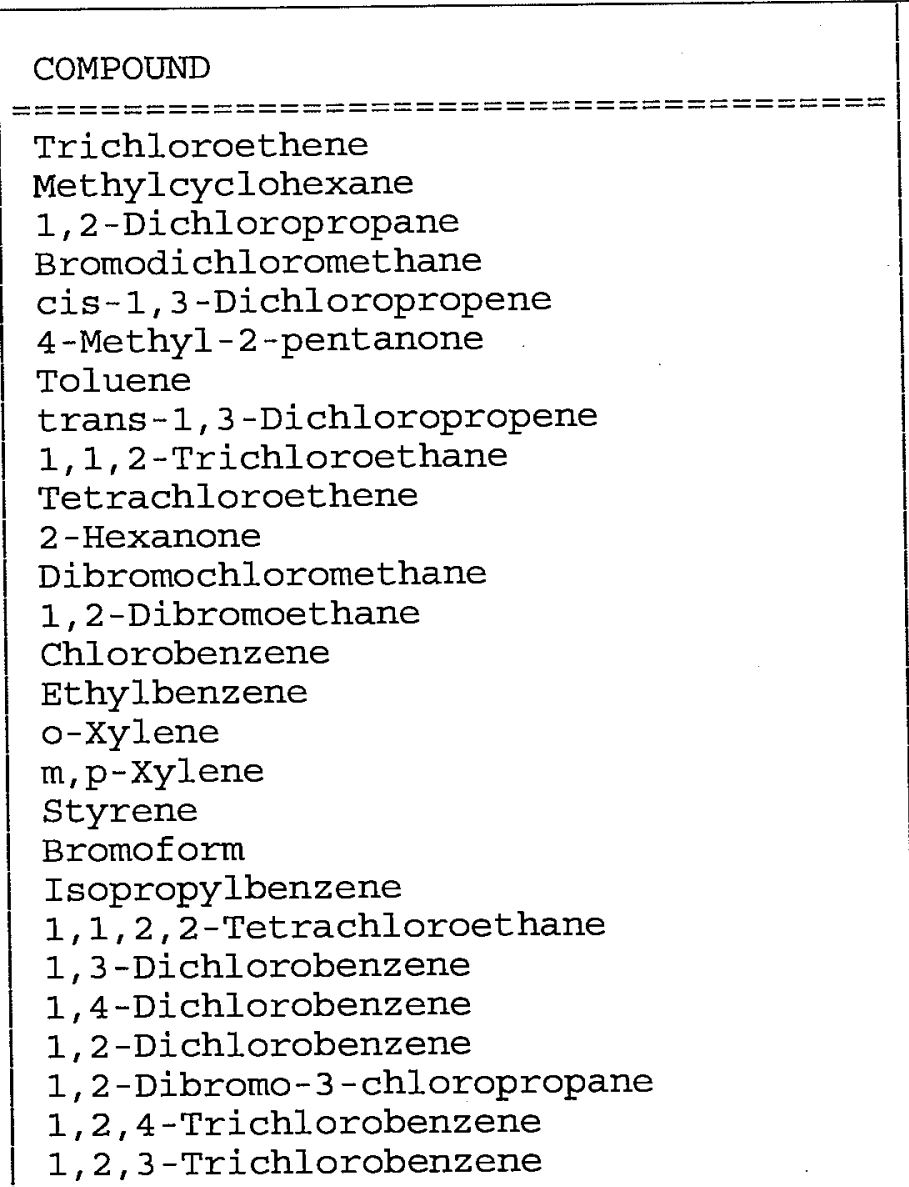 & 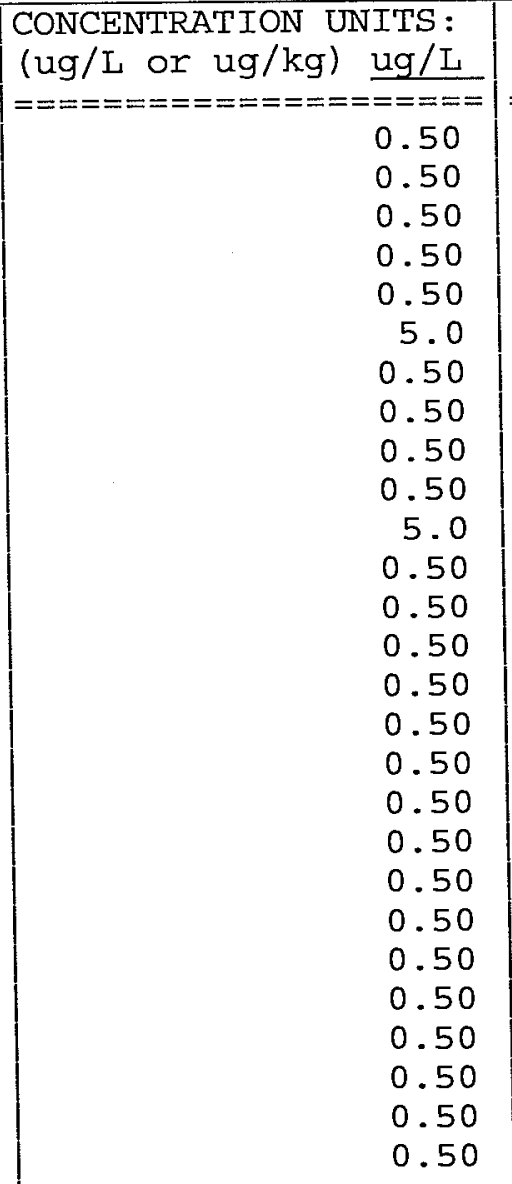 & \begin{tabular}{|l}
$======$ \\
$\mathrm{U}$ \\
$\mathrm{U}$ \\
$\mathrm{U}$ \\
$\mathrm{U}$ \\
$\mathrm{U}$ \\
$\mathrm{U}$ \\
$\mathrm{U}$ \\
$\mathrm{U}$ \\
$\mathrm{U}$ \\
$\mathrm{U}$ \\
$\mathrm{U}$ \\
$\mathrm{U}$ \\
$\mathrm{U}$ \\
$\mathrm{U}$ \\
$\mathrm{U}$ \\
$\mathrm{U}$ \\
$\mathrm{U}$ \\
$\mathrm{U}$ \\
$\mathrm{U}$ \\
$\mathrm{U}$ \\
$\mathrm{U}$ \\
$\mathrm{U}$ \\
$\mathrm{U}$ \\
$\mathrm{U}$ \\
$\mathrm{U}$ \\
$\mathrm{U}$ \\
$\mathrm{U}$
\end{tabular} \\
\hline
\end{tabular}




\section{TestAmerica}

THE LEADER IN ENYIRONMENTAL TESTING

TestAmerica Laboratories, Inc.

November 2, 2009

Mr. Clyde Dennis

Argonne National Laboratory

9700 S. Cass Avenue

Bldg. 203, Office B149

Argonne, IL 60439

Re: Laboratory Project No. 21005

Case: CENTRLIA; SDG: 134016

Dear Mr. Dennis:

Enclosed are analytical results for samples that were received by TestAmerica Burlington on

October $8^{\text {th }}, 2009$. Laboratory identification numbers were assigned, and designated as follows:

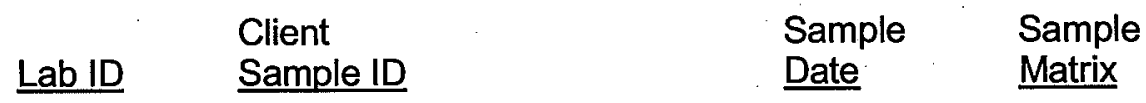

Received: 10/08/09 ETR No: 134016

$\begin{array}{llll}809271 & \text { CNMW10-W-27158 } & 10 / 06 / 09 & \text { WATER } \\ 809272 & \text { CNMW05-W-27153 } & 10 / 06 / 09 & \text { WATER } \\ 809273 & \text { CNPMP8-W-27172 } & 10 / 07 / 09 & \text { WATER } \\ 809274 & \text { CNQCTB-W-27178 } & 10 / 07 / 09 & \text { WATER } \\ 809275 & \text { VHBLK01 } & 10 / 09 / 09 & \text { WATER }\end{array}$

Documentation of the condition of the samples at the time of their receipt and any exception to the laboratory's Sample Acceptance Policy is documented in the Sample Handling section of this submittal. The samples, as received, were not acid preserved. On that basis, the laboratory attempted to provide for the analytical work to be performed within seven days of sample collection. The analysis of sample CNMW10-W-27158 did occur on the eighth day from the date that the sample was collected, and the analysis of sample CNMW05-W-27153 and did occur on the ninth day from the date that the sample was collected.

In order to accommodate field length limitations in processing the data summary forms, the laboratory did, in certain instances, abbreviate the sample identifier. The electronically formatted data provides for the full sample identifier.

\section{SOM01.2 Volatile Organics (Trace Level Water)}

A storage blank was prepared for volatile organics analysis, and stored in association with the storage of the samples. That storage blank, identified as VHBLK01, was carried through the 


\section{TestAmerica}

THE LEADER IN ENVIRONMENTAL TESTING

holding period with the samples, and analyzed.

Each of the analyses associated with the sample set exhibited an acceptable internal standard performance. There was an acceptable recovery of each deuterated monitoring compound (DMC) in the analysis of the method blank associated with the analytical work, and in the analysis of the storage blank associated with the sample set. The analysis of the samples in this sample set did meet the technical acceptance criteria specific to DMC recoveries, although not all DMC recoveries were within the control range in each analysis. The technical acceptance criteria does provide for the recovery of up to three DMCs to fall outside of the control range in the analysis of field samples. With the exception of that performed on sample CNMW05-W27153 , the analysis of each field sample did yield elevated recoveries of 2-butanone- $\mathrm{d}_{5}$ and 2 -hexanone- $d_{5}$. Matrix spike and matrix spike duplicate analyses were not performed on samples in this sample set. The analysis of each method blank associated with the analytical work was free of contamination, as was the analysis of the storage blank. Present in the method blank and storage blank analyses was a non-target constituent that represented a compound that is related to the DMC formulation. The fact that the presence of this compound is not within the laboratory's control is at issue. The derived results for that compound have been qualified with an "X" qualifier to reflect the source of the contamination.

The reported result for acetone from the analysis of sample CNPMP8-W-27172 was derived from a response that exceeded the range of calibrated instrument response. The derived concentration of acetone in that analysis was $220 \mathrm{ug} / \mathrm{L}$. The concentration of acetone in the high concentration standard in the initial calibration is $200 \mathrm{ug} / \mathrm{L}$. Given the compound at issue, and the fact that the derived concentration was within 10 percent of that in the high concentration standard, a secondary analysis of the sample was not performed.

With the exception of those for bromomethane in the initial calibration identified as "MZT", the responses for each of the target analytes met the relative standard deviation criterion in each initial calibration. The relative standard deviation of the responses for bromomethane in the referenced initial calibration was 35.2 percent. Although above the 30.0 percent relative standard deviation criterion established for that compound, the technical acceptance criteria for a compliant initial calibration were met. The response for each target analyte met the percent difference criterion in each continuing calibration check acquisition. The response for each target analyte met the 50.0 percent difference criterion in each closing calibration check acquisition.

The primary quantitation mass for methylcyclohexane that is specified in the Statement of Work is mass 83 . The laboratory did identify a contribution to mass 83 from 1,2-dichloropropane- $d_{6}$; one of the deuterated monitoring compounds (DMCs). The laboratory did change the primary quantitation mass assignment to mass 55 for the quantification of methylcyclohexane.

Manual integration was employed in deriving certain of the analytical results. The values that have been derived from manual integration are qualified on the quantitation reports. Extracted ion current profiles for each manual integration are included in the data package, and further documented in the Sample Preparation section of this submittal.

Any reference within this report to Severn Trent Laboratories, Inc. or STL, should be understood to refer to TestAmerica Laboratories, Inc. (formerly known as Severn Trent Laboratories, Inc.) The analytical results associated with the samples presented in this test report were generated 


\section{TestAmerica \\ THE LEADER: IN ENVIRONMENTAL TESTING}

under a quality system that adheres to requirements specified in the NELAC standard. Release of the data in this test report and any associated electronic deliverables is authorized by the Laboratory Director's. designee as verified by the following signature.

If there are any questions regarding this submittal, please contact me at 802 660-1990.

Sincerely,

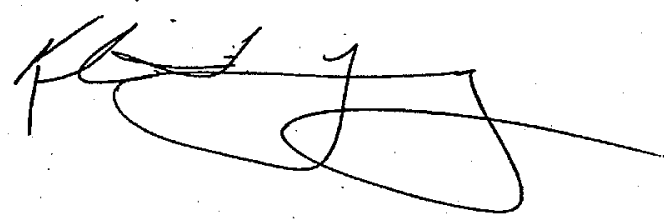

Kirk F. Young

Project Manager

$\mathrm{KFY/hsf}$

Enclosure 


\section{TestAmerica Burlington Data Qualifier Definitions}

\section{Organic}

$\mathrm{U}$ : Compound analyzed but not detected at a concentration above the reporting limit.

$\mathrm{J}: \quad$ Estimated value.

$\mathrm{N}$ : Indicates presumptive evidence of a compound. This flag is used only for tentatively identified compounds (TICs) where the identification of a compound is based on a mass spectral library search.

P: $\quad$ SW-846: The relative percent difference for detected concentrations between two GC columns is greater than $40 \%$. Unless otherwise specified the higher of the two values is reported on the Form I.

CLP SOW: Greater than 25\% difference for detected concentrations between two GC columns. Unless otherwise specified the lower of the two values is reported on the Form I.

C: Pesticide result whose identification has been confirmed by GC/MS.

B: Analyte is found in the sample and the associated method blank. The flag is used for tentatively identified compounds as well as positively identified compounds.

E: Compounds whose concentrations exceed the upper limit of the calibration range of the instrument for that specific analysis.

D: Concentrations identified from analysis of the sample at a secondary dilution.

A: Tentatively identified compound is a suspected aldol condensation product.

$X, Y, Z$ : Laboratory defined flags that may be used alone or combined, as needed. If used, the description of the flag is defined in the project narrative.

\section{Inorganic/Metals}

E: $\quad$ Reported value is estimated due to the presence of interference.

$\mathrm{N}: \quad$ Matrix spike sample recovery is not within control limits.

* Duplicate sample analysis is not within control limits.

B: The result reported is less than the reporting limit but greater than the instrument detection limit.

U: $\quad$ Analyte was analyzed for but not detected above the reporting limit.

Method Codes:

P ICP-AES

MS ICP-MS

CV Cold Vapor AA

AS Semi-Automated Spectrophotometric 


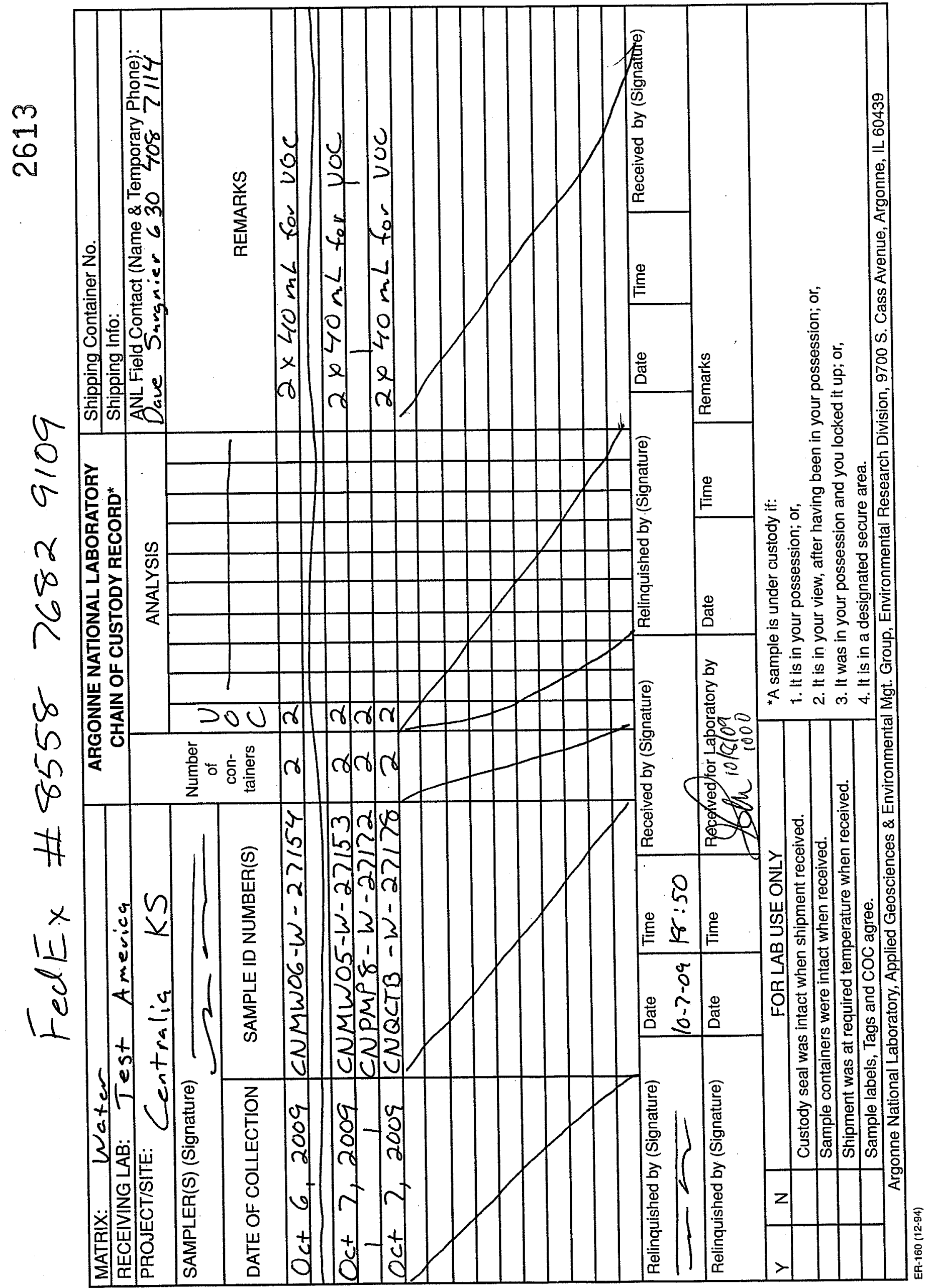




\section{TestAmerica \\ THE LEADER IN ENVIRONMENTAL. TESTING}

\section{Sample Data Summary - SOM01.2 Volatiles - Trace}


Lab Name: TESTAMERICA BURLINGTON Contract: $8 \mathrm{E}-00302$

Lab Code: STLV Case No.: CENTRLIA Mod. Ref No.:

SDG NO.: 134016

Matrix: (SOIL/SED/WATER) Water

Sample wt/vol: $25.0 \quad(\mathrm{~g} / \mathrm{mL}) \mathrm{mL}$

Level: (TRACE/LOW/MED) TRACE

$\%$ Moisture: not dec.

GC Column: DB-624

Soil Extract Volume:

ID : 0.53

Lab Sample ID: 809272

Purge Volume: 25.0 $(\mathrm{mm})$

(uL)

Lab File ID: 809272

Date Received: 10/08/2009

Date Analyzed: 10/15/2009

Dilution Factor: 1.0

Soil Aliquot Volume:

(uL)

(mL)

\begin{tabular}{|c|c|c|c|}
\hline CAS NO. & COMPOUND & $\begin{array}{l}\text { CONCENTRATION UNITS: } \\
(\mathrm{ug} / \mathrm{L} \text { or } \mathrm{ug} / \mathrm{kg}) \mathrm{ug} / \mathrm{L}\end{array}$ & $Q$ \\
\hline$===========1$ & 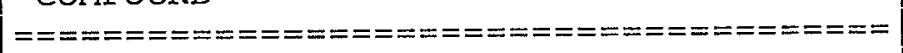 & $=================== \pm=$ & $==\tilde{=}====$ \\
\hline $75-71-8$ & Dichlorodifluoromethane & 0.50 & $\mathrm{U}$ \\
\hline $74-87-3$ & Chloromethane & 0.50 & $\mathrm{U}$ \\
\hline $75-01-4$ & Vinyl chloride & 0.50 & $\mathrm{U}$ \\
\hline $74-83-9$ & Bromomethane & 0.50 & $\mathrm{U}$ \\
\hline $75-00-3$ & Chloroethane & 0.50 & $\mathrm{U}$ \\
\hline $75-69-4$ & Trichlorofluoromethane & 0.50 & $\mathrm{U}$ \\
\hline $75-35-4$ & 1,1-Dichloroethene & 0.50 & $\mathrm{U}$ \\
\hline $76-13-1$ & $1,1,2$-Trichloro-1,2,2-trifluoroethane & 0.50 & $\mathrm{U}$ \\
\hline $67-64-1$ & Acetone & 5.0 & $\mathrm{U}$ \\
\hline $75-15-0$ & Carbon disulfide & 0.50 & $\mathrm{U}$ \\
\hline $79-20-9$ & Methyl acetate & 0.50 & $\mathrm{U}$ \\
\hline $75-09-2$ & Methylene chloride & 0.50 & $\mathrm{U}$ \\
\hline $156-60-5$ & trans-1,2-Dichloroethene & 0.50 & $\mathrm{U}$ \\
\hline $1634-04-4$ & Methyl tert-butyl ether & 0.50 & $\mathrm{U}$ \\
\hline $75-34-3$ & 1,1-Dichloroethane & 0.50 & $\mathrm{U}$ \\
\hline $156-59-2$ & cis-1,2-Dichloroethene & 0.50 & $\mathrm{U}$ \\
\hline $78-93-3$ & 2-Butanone & 5.0 & $\mathrm{U}$ \\
\hline $74-97-5$ & Bromochloromethane & 0.50 & $\mathrm{U}$ \\
\hline $67-66-3$ & Chloroform & 1.1 & \\
\hline $71-55-6$ & $1,1,1$-Trichloroethane & 0.50 & $\overline{\mathrm{U}}$ \\
\hline $110-82-7$ & Cyclohexane & 0.50 & $\mathrm{U}$ \\
\hline $56-23-5$ & Carbon tetrachloride & 14 & \\
\hline $71-43-2$ & Benzene & 0.50 & $\overline{\mathrm{U}}$ \\
\hline $107-06-2$ & 1,2-Dichloroethane & 0.50 & $\mathrm{U}$ \\
\hline
\end{tabular}

Report 1,4-Dioxane for Low-Medium VOA analysis only 
Lab Name: TESTAMERICA BURLINGTON

Contract: $8 \mathrm{E}-00302$

Lab Code: STLV Case No.: CENTRLIA Mod. Ref No.:

SDG No. : 134016

Matrix: (SOIL/SED/WATER) water

Sample wt/vol: 25.0

$(\mathrm{g} / \mathrm{mL}) \mathrm{mL}$

Level: (TRACE/LOW/MED) TRACE

\% Moisture: not dec.

GC Column: DB-624

$I D: 0.53$

Soil Extract Volume:

Purge Volume: 25.0
Lab Sample ID: 809272

Lab File ID: 809272

Date Received: 10/08/2009

Date Analyzed: 10/15/2009

Dilution Factor: 1.0

Soil Aliquot Volume:

(mL)

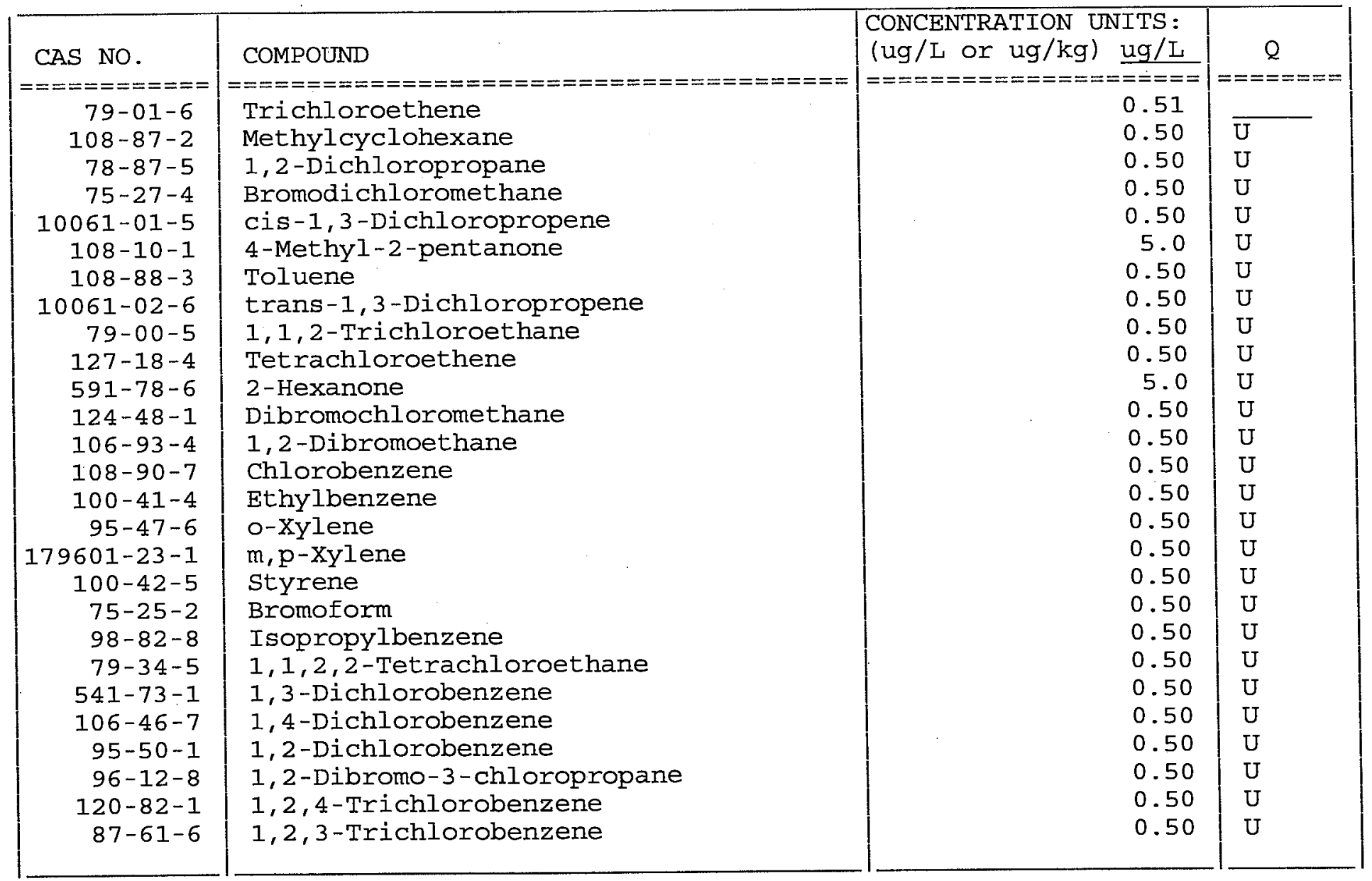


Lab Name: TESTAMERICA BURLINGTON

Contract: $8 \mathrm{E}-00302$

Lab Code: STLV Case No.: CENTRLIA Mod. Ref No.:

SDG No.: 134016

Matrix: (SOIL/SED/WATER) Water

Sample wt/vol: 25.0

$(\mathrm{g} / \mathrm{mL}) \mathrm{mL}$

Level: (TRACE/LOW/MED) TRACE

\% Moisture: not dec.

GC Column: DB-624

Soil Extract Volume:

ID $: 0.53$

(mm)

(UL)

(mL)
Lab Sample ID: 809271

Lab File ID: 809271

Date Received: 10/08/2009

Date Analyzed: 10/14/2009

Dilution Factor: 1.0

Soil Aliquot Volume:

(uL)

Purge Volume: 25.0

\begin{tabular}{|c|c|c|c|}
\hline CAS NO. & COMPOUND & $\begin{array}{l}\text { CONCENTRATION UNITS: } \\
\text { (ug/L or ug/kg) } \mathrm{ug} / \mathrm{L}\end{array}$ & Q \\
\hline$==========$ & 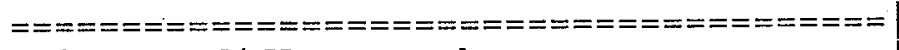 & 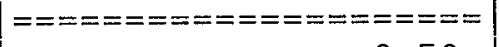 & $======$ \\
\hline $75-71-8$ & Dichlorodifluoromethane & 0.50 & U \\
\hline $74-87-3$ & Chloromethane & 0.50 & $\mathrm{U}$ \\
\hline $75-01-4$ & Vinyl chloride & 0.50 & $\mathrm{U}$ \\
\hline $74-83-9$ & Bromomethane & 0.50 & $\mathrm{U}$ \\
\hline $75-00-3$ & Chloroethane & 0.50 & $\mathrm{U}$ \\
\hline $75-69-4$ & Trichlorofluoromethane & 0.50 & $\mathrm{U}$ \\
\hline $75-35-4$ & 1,1-Dichloroethene & 0.50 & $\mathrm{U}$ \\
\hline $76-13-1$ & $1,1,2$-Trichloro-1,2,2-trifluoroethane & 0.50 & $\mathrm{U}$ \\
\hline $67-64-1$ & Acetone & 5.0 & $\mathrm{U}$ \\
\hline $75-15-0$ & Carbon disulfide & 0.50 & $\mathrm{U}$ \\
\hline $79-20-9$ & Methyl acetate & 0.50 & $\mathrm{U}$ \\
\hline $75-09-2$ & Methylene chloride & 0.50 & $\mathrm{U}$ \\
\hline $156-60-5$ & trans-1,2-Dichloroethene & 0.50 & $\mathrm{U}$ \\
\hline $1634-04-4$ & Methyl tert-butyl ether & 0.50 & $\mathrm{U}$ \\
\hline $75-34-3$ & 1,1-Dichloroethane & 0.50 & $\mathrm{U}$ \\
\hline $156-59-2$ & cis-1,2-Dichloroethene & 0.50 & $\mathrm{U}$ \\
\hline $78-93-3$ & 2-Butanone & 5.0 & $\mathrm{U}$ \\
\hline $74-97-5$ & Bromochloromethane & 0.50 & $\mathrm{U}$ \\
\hline $67-66-3$ & Chloroform & 0.50 & $\mathrm{U}$ \\
\hline $71-55-6$ & $1,1,1$-Trichloroethane & 0.50 & $\mathrm{U}$ \\
\hline $110-82-7$ & Cyclohexane & 0.50 & $\mathrm{U}$ \\
\hline $56-23-5$ & Carbon tetrachloride & 0.50 & $\mathrm{U}$ \\
\hline $71-43-2$ & Benzene & 0.50 & $\mathrm{U}$ \\
\hline $107-06-2$ & 1,2-Dichloroethane & 0.50 & $\mathrm{U}$ \\
\hline
\end{tabular}

Report 1,4-Dioxane for Low-Medium VOA analysis only 
Lab Name: TESTAMERICA BURLINGTON

Lab Code: STLV Case No.: CENTRLIA Mod. Ref No.:
Contract: 8E-00302

SDG NO.: 134016
Matrix: (SOIL/SED/WATER) Water

Sample wt/vol: 25.0

$(\mathrm{g} / \mathrm{mL}) \mathrm{mL}$

Level: (TRACE/LOW/MED) TRACE

\% Moisture: not dec.

GC Column: DB-624

Soil Extract Volume:

ID $: 0.53$

$(\mathrm{mm})$

(uL)

Lab Sample ID: 809271

Purge Volume: 25.0

(mL)
Lab File ID: 809271

Date Received: 10/08/2009

Date Analyzed: 10/14/2009

Dilution Factor: 1.0

Soil Aliquot Volume:

(uL)

\begin{tabular}{|c|c|c|c|}
\hline CAS NO. & COMPOUND & $\begin{array}{l}\text { CONCENTRATION UNITS: } \\
(\mathrm{ug} / \mathrm{L} \text { or } \mathrm{ug} / \mathrm{kg}) \mathrm{ug} / \mathrm{L}\end{array}$ & $Q$ \\
\hline$==========$ & 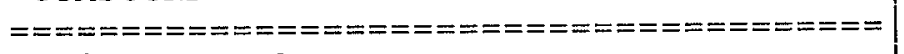 & $===================0$ & $======$ \\
\hline $79-01-6$ & Trichloroethene & 0.50 & $\mathrm{U}$ \\
\hline $108-87-2$ & Methylcyclohexane & 0.50 & $\mathrm{U}$ \\
\hline $78-87-5$ & 1,2-Dichloropropane & 0.50 & $\mathrm{U}$ \\
\hline $75-27-4$ & Bromodichloromethane & 0.50 & $\mathrm{U}$ \\
\hline $10061-01-5$ & cis-1,3-Dichloropropene & 0.50 & $\mathrm{U}$ \\
\hline $108-10-1$ & 4-Methyl-2-pentanone & 5.0 & $\mathrm{U}$ \\
\hline $108-88-3$ & Toluene & 0.50 & $\mathrm{U}$ \\
\hline $10061-02-6$ & trans-1,3-Dichloropropene & 0.50 & $\mathrm{U}$ \\
\hline $79-00-5$ & $1,1,2$-Trichloroethane & 0.50 & $\mathrm{U}$ \\
\hline $127-18-4$ & Tetrachloroethene & 0.50 & $\mathrm{U}$ \\
\hline $591-78-6$ & 2-Hexanone & 5.0 & $\mathrm{U}$ \\
\hline $124-48-1$ & Dibromochloromethane & 0.50 & $\mathrm{U}$ \\
\hline $106-93-4$ & 1,2-Dibromoethane & 0.50 & $\mathrm{U}$ \\
\hline $108-90-7$ & Chlorobenzene & 0.50 & $\mathrm{U}$ \\
\hline $100-41-4$ & Ethylbenzene & 0.50 & $\mathrm{U}$ \\
\hline $95-47-6$ & o-xylene & 0.50 & $\mathrm{U}$ \\
\hline $179601-23-1$ & $\mathrm{~m}, \mathrm{p}$-Xylene & 0.50 & $\mathrm{U}$ \\
\hline $100-42-5$ & styrene & 0.50 & $\mathrm{U}$ \\
\hline $75-25-2$ & Bromoform & 0.50 & $\mathrm{U}$ \\
\hline $98-82-8$ & Isopropylbenzene & 0.50 & $\mathrm{U}$ \\
\hline $79-34-5$ & $1,1,2,2$-Tetrachloroethane & 0.50 & $\mathrm{U}$ \\
\hline $541-73-1$ & 1,3-Dichlorobenzene & 0.50 & $\mathrm{U}$ \\
\hline $106-46-7$ & 1,4 -Dichlorobenzene & 0.50 & $\mathrm{U}$ \\
\hline $95-50-1$ & 1,2 -Dichlorobenzene & 0.50 & $\mathrm{U}$ \\
\hline $96-12-8$ & 1,2-Dibromo-3-chloropropane & 0.50 & $\mathrm{U}$ \\
\hline $120-82-1$ & $1,2,4$-Trichlorobenzene & 0.50 & $\mathrm{U}$ \\
\hline $87-61-6$ & 1,2,3-Trichlorobenzene & 0.50 & $\mathrm{U}$ \\
\hline
\end{tabular}


$1 A$ - FORM I VOA-1

VOLATILE ORGANICS ANALYSIS DATA SHEET
EPA SAMPLE NO.
Lab Name: TESTAMERICA BURLINGTON

Lab Code: STLV Case No.: CENTRLIA Mod. Ref No.:
Contract: $8 E-00302$

SDG NO.: 134016
Matrix: (SOIL/SED/WATER) Water

Sample wt/vol: 25.0

$(\mathrm{g} / \mathrm{mL}) \mathrm{mL}$

Level: (TRACE/LOW/MED) TRACE

\% Moisture: not dec.

GC Column: DB-624

ID $: 0.53$

Soil Extract Volume:

Purge Volume: 25.0
Lab Sample ID: 809273

Lab File ID: 809273

Date Received: 10/08/2009

Date Analyzed: 10/14/2009

Dilution Factor: 1.0

Soil Aliquot Volume:

$(\mathrm{mLi})$

\begin{tabular}{|c|c|c|c|}
\hline CAS NO. & COMPOUND & $\begin{array}{l}\text { CONCENTRATION UNITS: } \\
(\mathrm{ug} / \mathrm{L} \text { or } \mathrm{ug} / \mathrm{kg}) \mathrm{ug} / \mathrm{L}\end{array}$ & Q \\
\hline$===========$ & $=0==$ & $====================$ & $=======$ \\
\hline $75-71-8$ & Dichlorodifluoromethane & 0.50 & U \\
\hline $74-87-3$ & Chloromethane & 0.50 & $\mathrm{U}$ \\
\hline $75-01-4$ & Vinyl chloride & 0.50 & U \\
\hline $74-83-9$ & Bromomethane & 0.50 & U \\
\hline $75-00-3$ & Chloroethane & 0.50 & U \\
\hline $75-69-4$ & Trichlorofluoromethane & 0.50 & $\mathrm{U}$ \\
\hline $75-35-4$ & 1,1-Dichloroethene & 0.50 & $\mathrm{U}$ \\
\hline $76-13-1$ & $1,1,2$-Trichloro-1,2,2-trifluoroethane & 0.50 & $\mathrm{U}$ \\
\hline $67-64-1$ & Acetone & 220 & $E$ \\
\hline $75-15-0$ & Carbon disulfide & 0.56 & \\
\hline $79-20-9$ & Methyl acetate & 0.50 & $\mathrm{U}$ \\
\hline $75-09-2$ & Methylene chloride & 0.98 & \\
\hline $156-60-5$ & trans-1,2-Dichloroethene & 0.50 & $\overline{\mathrm{U}}$ \\
\hline $1634-04-4$ & Methyl tert-butyl ether & 0.50 & $\mathrm{U}$ \\
\hline $75-34-3$ & 1,1-Dichloroethane & 0.50 & U \\
\hline $156-59-2$ & cis-1,2-Dichloroethene & 0.50 & $\mathrm{U}$ \\
\hline $78-93-3$ & 2-Butanone & 120 & \\
\hline $74-97-5$ & Bromochloromethane & 0.50 & U \\
\hline $67-66-3$ & Chloroform & 18 & \\
\hline $71-55-6$ & $1,1,1$-Trichloroethane & 0.50 & $\bar{U}$ \\
\hline $110-82-7$ & Cyclohexane & 0.50 & U \\
\hline $56-23-5$ & Carbon tetrachloride & 18 & \\
\hline $71-43-2$ & Benzene & 0.50 & $\overline{\mathrm{U}}$ \\
\hline $107-06-2$ & 1,2-Dichloroethane & 0.50 & $\mathrm{U}$ \\
\hline
\end{tabular}

Report 1,4-Dioxane for Low-Medium VOA analysis only 
Lab Name: TESTAMERICA BURLINGTON

Lab Code: STLV Case No.: CENTRLIA Mod. Ref No.:
Contract: 8E-00302

SDG No.: 134016
Matrix: (SOIL/SED/WATER) Water

Sample wt/vol: 25.0

$(\mathrm{g} / \mathrm{mL}) \mathrm{mL}$

Level: (TRACE/LOW/MED) TRACE

\% Moisture: not dec.

GC Column: DB-624

Soil Extract Volume:

ID $: 0.53$

(mm)

(uL)

$(\mathrm{mL})$
Lab Sample ID: 809273

Lab File ID: 809273

Date Received: 10/08/2009

Date Analyzed: 10/14/2009

Dilution Factor: 1.0

Soil Aliquot Volume:

(uL)

\begin{tabular}{|c|c|c|c|}
\hline CAS NO. & COMPOUND & $\begin{array}{l}\text { CONCENTRATION UNITS: } \\
(\mathrm{ug} / \mathrm{L} \text { or } \mathrm{ug} / \mathrm{kg}) \mathrm{ug} / \mathrm{L}\end{array}$ & Q \\
\hline$===========$ & 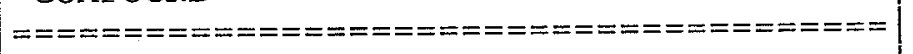 & $===\dot{=}========= \pm===== \pm$ & $========$ \\
\hline $79-01-6$ & Trichloroethene & 0.50 & $\mathrm{U}$ \\
\hline $108-87-2$ & Methylcyclohexane & 0.50 & U \\
\hline $78-87-5$ & 1,2-Dichloropropane & 0.50 & U \\
\hline $75-27-4$ & Bromodichloromethane & 0.50 & $\mathrm{U}$ \\
\hline $10061-01-5$ & cis-1,3-Dichloropropene & 0.50 & $\mathrm{U}$ \\
\hline $108-10-1$ & 4-Methyl-2-pentanone & 5.0 & $\mathrm{U}$ \\
\hline $108-88-3$ & Toluene & 2.6 & \\
\hline $10061-02-6$ & trans-1,3-Dichloropropene & 0.50 & $\overline{\mathrm{U}}$ \\
\hline $79-00-5$ & $1,1,2$-Trichloroethane & 0.50 & U \\
\hline $127-18-4$ & Tetrachloroethene & 0.50 & U \\
\hline $591-78-6$ & 2 -Hexanone & 5.0 & U \\
\hline $124-48-1$ & Dibromochloromethane & 0.50 & U \\
\hline $106-93-4$ & 1,2-Dibromoethane & 0.50 & U \\
\hline $108-90-7$ & Chlorobenzene & 0.50 & $\mathrm{U}$ \\
\hline $100-41-4$ & Ethylbenzene & 0.50 & $\mathrm{U}$ \\
\hline $95-47-6$ & o-Xylene & 0.50 & $\mathrm{U}$ \\
\hline $179601-23-1$ & $\mathrm{~m}, \mathrm{p}-\mathrm{Xy}$ lene & 0.50 & U \\
\hline $100-42-5$ & Styrene & 0.50 & $\mathrm{U}$ \\
\hline $75-25-2$ & Bromoform & 0.50 & U \\
\hline $98-82-8$ & Isopropylbenzene & 0.50 & $\mathrm{U}$ \\
\hline $79-34-5$ & $1,1,2,2$-Tetrachloroethane & 0.50 & $\mathrm{U}$ \\
\hline $541-73-1$ & 1,3-Dichlorobenzene & 0.50 & $\mathrm{U}$ \\
\hline $106-46-7$ & 1,4-Dichlorobenzene & 0.50 & U \\
\hline $95-50-1$ & 1,2-Dichlorobenzene & 0.50 & $\mathrm{U}$ \\
\hline $96-12-8$ & 1,2-Dibromo-3-chloropropane & 0.50 & $\mathrm{U}$ \\
\hline $120-82-1$ & $1,2,4$-Trichlorobenzene & 0.50 & $\mathrm{U}$ \\
\hline $87-61-6$ & $1,2,3$-Trichlorobenzene & 0.50 & $\mathrm{U}$ \\
\hline
\end{tabular}


Lab Name: TESTAMERICA BURLINGTON

Lab Code: STLV Case No.: CENTRLIA Mod. Ref No.:
Contract: $8 E-00302$

SDG No.: 134016

\section{Matrix: (SOIL/SED/WATER) Water}

Sample wt/vol: 25.0

$$
(\mathrm{g} / \mathrm{mL}) \mathrm{mL}
$$

Level: (TRACE/LOW/MED) TRACE

\% Moisture: not dec.

GC Column: DB-624

ID : 0.53

(mm)

(uL)

(mL)

Purge Volume: 25.0
Lab Sample ID: 809274

Lab File ID: 809274

Date Received: 10/08/2009

Date Analyzed: 10/14/2009

Dilution Factor: 1.0

Soil Aliquot Volume:

$(\mathrm{mL})$

\begin{tabular}{|c|c|c|c|}
\hline $\begin{array}{l}\text { CAS NO. } \\
========= \\
75-71-8 \\
74-87-3 \\
75-01-4 \\
74-83-9 \\
75-00-3 \\
75-69-4 \\
75-35-4 \\
76-13-1 \\
67-64-1 \\
75-15-0 \\
79-20-9 \\
75-09-2 \\
156-60-5 \\
1634-04-4 \\
75-34-3 \\
156-59-2 \\
78-93-3 \\
74-97-5 \\
67-66-3 \\
71-55-6 \\
110-82-7 \\
56-23-5 \\
71-43-2 \\
107-06-2\end{array}$ & $\begin{array}{l}\text { COMPOUND } \\
=========================== \\
\text { Dichlorodifluoromethane } \\
\text { Chloromethane } \\
\text { Vinyl chloride } \\
\text { Bromomethane } \\
\text { Chloroethane } \\
\text { Trichlorofluoromethane } \\
1,1-D i c h l o r o e t h e n e \\
1,1,2-\text { Trichloro-1, } 2,2-\text { trifluoroethane } \\
\text { Acetone } \\
\text { Carbon disulfide } \\
\text { Methyl acetate } \\
\text { Methylene chloride } \\
\text { trans-1,2-Dichloroethene } \\
\text { Methyl tert-butyl ether } \\
1,1-D i c h l o r o e t h a n e \\
\text { cis-1,2-Dichloroethene } \\
2-\text { Butanone } \\
\text { Bromochloromethane } \\
\text { Chloroform } \\
1,1,1-\text { Trichloroethane } \\
\text { Cyclohexane } \\
\text { Carbon tetrachloride } \\
\text { Benzene } \\
1,2-D i c h l o r o e t h a n e\end{array}$ & 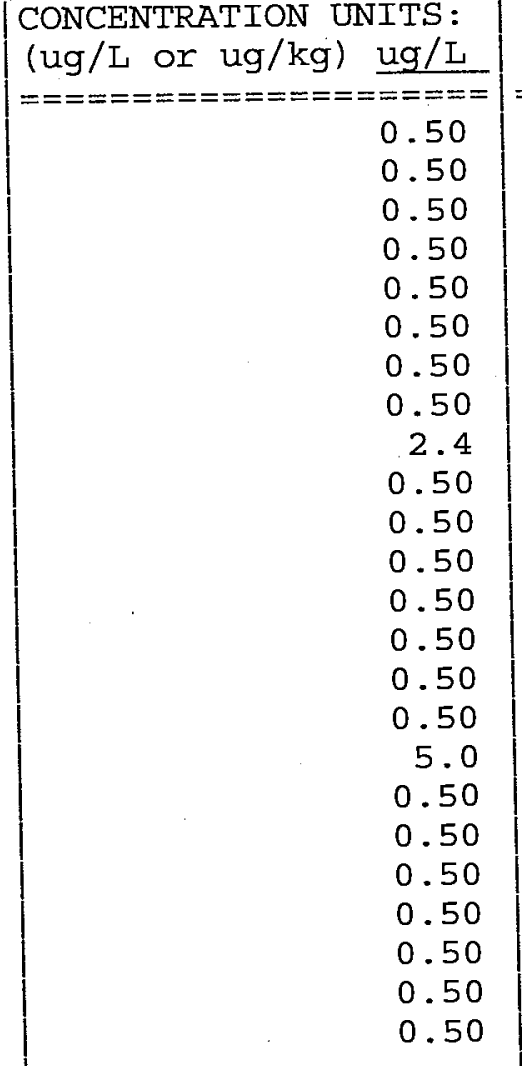 & $\begin{array}{l}========== \\
U \\
U \\
U \\
U \\
U \\
U \\
U \\
U \\
J \\
U \\
U \\
U \\
U \\
U \\
U \\
U \\
U \\
U \\
U \\
U \\
U \\
U \\
U \\
U\end{array}$ \\
\hline
\end{tabular}

Report 1,4-Dioxane for Low-Medium VOA analysis only 
Lab Name: TESTAMERICA BURLINGTON

Lab Code: STLV Case No.: CENTRLIA Mod. Ref No.:
Contract : $8 \mathrm{E}-00302$

\section{Matrix: (SOIL/SED/WATER) Water}

Sample wt/vol: 25.0

$(\mathrm{g} / \mathrm{mL}) \mathrm{mL}$

Level: (TRACE/LOW/MED) TRACE

\% Moisture: not dec.

GC Column: DB-624

$I D: 0.53$

Soil Extract Volume:

Purge Volume: 25.0
Lab Sample ID: 809274

Lab File ID: 809274

Date Received: 10/08/2009

Date Analyzed: 10/14/2009

Dilution Factor: 1.0

Soil Aliquot Volume:

(mL)

\begin{tabular}{|c|c|c|c|}
\hline CAS NO. & COMPOUND & $\begin{array}{l}\text { CONCENTRATION UNITS: } \\
\text { (ug/L or } \mathrm{ug} / \mathrm{kg}) \mathrm{ug} / \mathrm{L}\end{array}$ & $Q$ \\
\hline$===========$ & 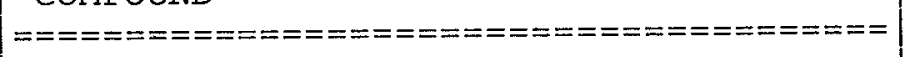 & $====================$ & $========$ \\
\hline $79-01-6$ & Trichloroethene & 0.50 & $\mathrm{U}$ \\
\hline $108-87-2$ & Methylcyclohexane & 0.50 & $\mathrm{U}$ \\
\hline $78-87-5$ & 1,2-Dichloropropane & 0.50 & U \\
\hline $75-27-4$ & Bromodichloromethane & 0.50 & $\mathrm{U}$ \\
\hline $10061-01-5$ & cis-1,3-Dichloropropene & 0.50 & $\mathrm{U}$ \\
\hline $108-10-1$ & 4-Methyl-2-pentanone & 5.0 & $\mathrm{U}$ \\
\hline $108-88-3$ & Toluene & 0.30 & J \\
\hline $10061-02-6$ & trans-1,3-Dichloropropene & 0.50 & $\mathrm{U}$ \\
\hline $79-00-5$ & $1,1,2$-Trichloroethane & 0.50 & $\mathrm{U}$ \\
\hline $127-18-4$ & Tetrachloroethene & 0.50 & $\mathrm{U}$ \\
\hline $591-78-6$ & 2 -Hexanone & 5.0 & $\mathrm{U}$ \\
\hline $124-48-1$ & Dibromochloromethane & 0.50 & $\mathrm{U}$ \\
\hline $106-93-4$ & 1,2-Dibromoethane & 0.50 & $\mathrm{U}$ \\
\hline $108-90-7$ & Chlorobenzene & 0.50 & $\mathrm{U}$ \\
\hline $100-41-4$ & Ethylbenzene & 0.50 & $\mathrm{U}:$ \\
\hline $95-47-6$ & o-Xylene & 0.50 & $\mathrm{U}$ \\
\hline $179601-23-1$ & $\mathrm{~m}, \mathrm{p}$-Xylene & 0.50 & $\mathrm{U}$ \\
\hline $100-42-5$ & styrene & 0.50 & $\mathrm{U}$ \\
\hline $75-25-2$ & Bromoform & 0.50 & $\mathrm{U}$ \\
\hline $98-82-8$ & Isopropylbenzene & 0.50 & $\mathrm{U}$ \\
\hline $79-34-5$ & $1,1,2,2$-Tetrachloroethane & 0.50 & $\mathrm{U}$ \\
\hline $541-73-1$ & 1,3-Dichlorobenzene & 0.50 & $\mathrm{U}$ \\
\hline $106-46-7$ & 1,4-Dichlorobenzene & 0.50 & $\mathrm{U}$ \\
\hline $95-50-1$ & 1,2-Dichlorobenzene & 0.50 & $\mathrm{U}$ \\
\hline $96-12-8$ & 1,2-Dibromo-3-chloropropane & 0.50 & $\mathrm{U}$ \\
\hline $120-82-1$ & $1,2,4$-Trichlorobenzene & 0.50 & $\mathrm{U}$ \\
\hline $87-61-6$ & $1,2,3$-Trichlorobenzene & 0.50 & $\mathrm{U}$ \\
\hline
\end{tabular}


$1 A$ - FORM I VOA-I

VOLATILE ORGANICS ANALYSIS DATA SHEET

Lab Name: TESTAMERICA BURLINGTON

Lab Code: STLV Case No.: CENTRLIA Mod. Ref No.:
Contract : $8 \mathrm{E}-00302$
Matrix: (SOIL/SED/WATER) Water

Sample wt/vol: 25.0

$(\mathrm{g} / \mathrm{mL}) \mathrm{mL}$

Level: (TRACE/LOW/MED) TRACE

\% Moisture: not dec.

GC Column: DB-624

ID $: 0.53$

Soil Extract Volume:

Purge Volume: 25.0
Lab Sample ID: 809275

Lab File ID: 809275

Date Received:

Date Analyzed: 10/17/2009

Dilution Factor: 1.0

(uL) Soil Aliquot Volume:

(uL)

\begin{tabular}{|c|c|c|c|}
\hline \begin{tabular}{|c|} 
CAS NO. \\
$==========$ \\
$75-71-8$ \\
$74-87-3$ \\
$75-01-4$ \\
$74-83-9$ \\
$75-00-3$ \\
$75-69-4$ \\
$75-35-4$ \\
$76-13-1$ \\
$67-64-1$ \\
$75-15-0$ \\
$79-20-9$ \\
$75-09-2$ \\
$156-60-5$ \\
$1634-04-4$ \\
$75-34-3$ \\
$156-59-2$ \\
$78-93-3$ \\
$74-97-5$ \\
$67-66-3$ \\
$71-55-6$ \\
$110-82-7$ \\
$56-23-5$ \\
$71-43-2$ \\
$107-06-2$
\end{tabular} & 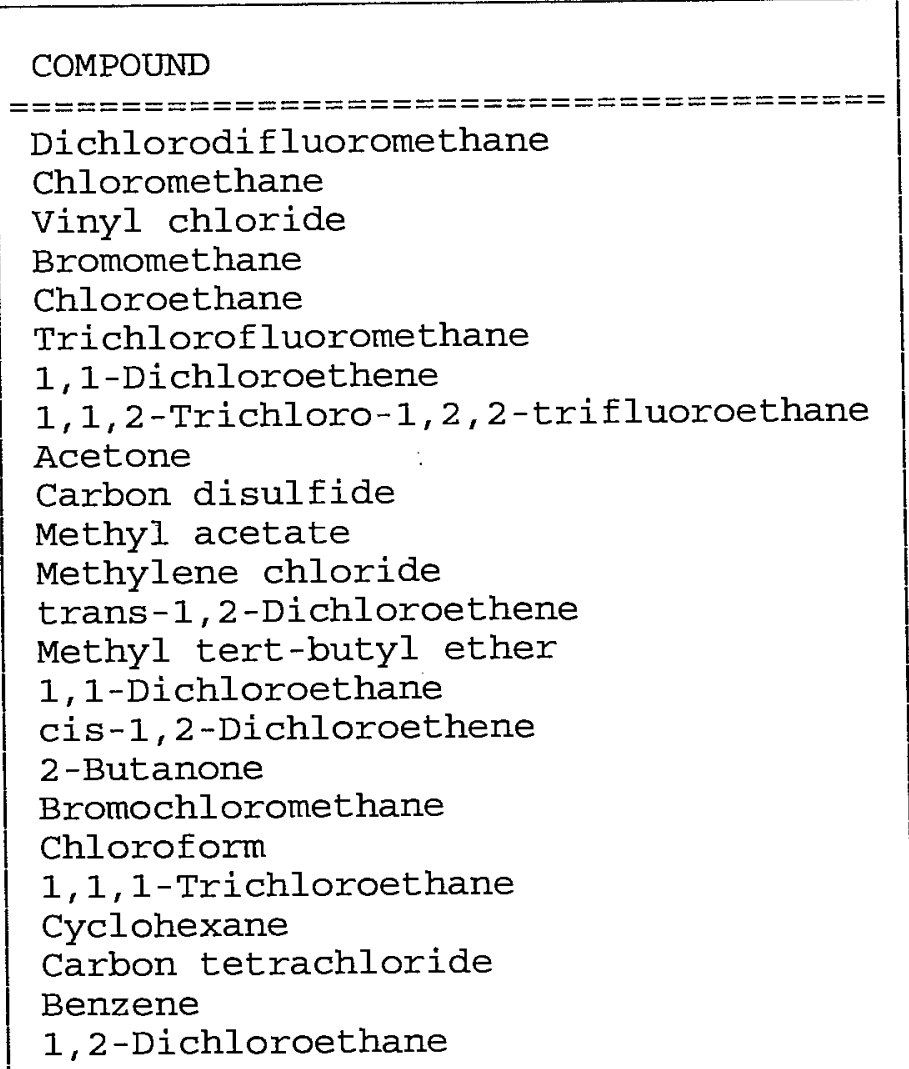 & $\begin{array}{|cr|}\text { CONCENTRATION UNITS : } \\
\text { (ug/L or ug/kg) } & \text { ug/L } \\
================== \\
0.50 \\
0.50 \\
0.50 \\
0.50 \\
0.50 \\
0.50 \\
0.50 \\
0.50 \\
5.0 \\
0.50 \\
0.50 \\
0.50 \\
0.50 \\
0.50 \\
0.50 \\
0.50 \\
5.0 \\
0.50 \\
0.50 \\
0.50 \\
0.50 \\
0.50 \\
0.50 \\
0.50\end{array}$ & $\begin{array}{l}======= \\
U \\
U \\
U \\
U \\
U \\
U \\
U \\
U \\
U \\
U \\
U \\
U \\
U \\
U \\
U \\
U . \\
U \\
U \\
U \\
U \\
U \\
U \\
U \\
U\end{array}$ \\
\hline
\end{tabular}

Report 1,4-Dioxane for Low-Medium VOA analysis only 
Lab Name: TESTAMERICA BURLINGTON

Contract: $8 \mathrm{E}-00302$

Lab Code: STLV Case No.: CENTRLIA Mod. Ref No.:

SDG No.: 134016

Matrix: (SOIL/SED/WATER) water

Sample wt/vol: $25.0 \quad(\mathrm{~g} / \mathrm{mL}) \mathrm{mL}$

Level: (TRACE/LOW/MED) TRACE

\% Moisture: not dec.

GC Column: DB-624 ID: 0.53 (mm) Dilution Factor: 1.0

Soil Extract Volume:

Purge Volume: 25.0
(uL) Soil Aliquot Volume:

Lab Sample ID: 809275

Lab File ID: 809275

Date Received:

Date Analyzed: 10/17/2009

(mL)

\begin{tabular}{|c|c|c|c|}
\hline CAS NO. & COMPOUND & $\begin{array}{l}\text { CONCENTRATION UNITS: } \\
(\mathrm{ug} / \mathrm{L} \text { or } \mathrm{ug} / \mathrm{kg} \text { ) } \mathrm{ug} / \mathrm{L}\end{array}$ & $Q$ \\
\hline$===========$ & 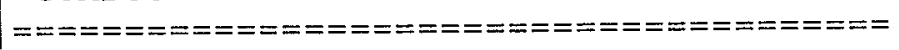 & $====================$ & $== \pm====0$ \\
\hline $79-01-6$ & Trichloroethene & 0.50 & $\mathrm{U}$ \\
\hline $108-87-2$ & Methylcyclohexane & 0.50 & $\mathrm{U}$ \\
\hline $78-87-5$ & 1,2-Dichloropropane & 0.50 & $\mathrm{U}$ \\
\hline $75-27-4$ & Bromodichloromethane & 0.50 & $\mathrm{U}$ \\
\hline $10061-01-5$ & cis-1,3-Dichloropropene & 0.50 & $\mathrm{U}$ \\
\hline $108-10-1$ & 4-Methyl-2-pentanone & 5.0 & $\mathrm{U}$ \\
\hline $108-88-3$ & Toluene & 0.50 & $\mathrm{U}$ \\
\hline $10061-02-6$ & trans-1,3-Dichloropropene & 0.50 & $\mathrm{U}$ \\
\hline $79-00-5$ & $1,1,2$-Trichloroethane & 0.50 & $\mathrm{U}$ \\
\hline $127-18-4$ & Tetrachloroethene & 0.50 & $\mathrm{U}$ \\
\hline $591-78-6$ & 2-Hexanone & 5.0 & $\mathrm{U}$ \\
\hline $124-48-1$ & Dibromochloromethane & 0.50 & $\mathrm{U}$ \\
\hline $106-93-4$ & 1,2-Dibromoethane & 0.50 & $\mathrm{U}$ \\
\hline $108-90-7$ & Chlorobenzene & 0.50 & $\mathrm{U}$ \\
\hline $100-41-4$ & Ethylbenzene & 0.50 & $\mathrm{U}$ \\
\hline $95-47-6$ & o-Xylene & 0.50 & $\mathrm{U}$ \\
\hline $179601-23-1$ & $\mathrm{~m}, \mathrm{p}$-Xylene & 0.50 & $\mathrm{U}$ \\
\hline $100-42-5$ & styrene & 0.50 & $\mathrm{U}$ \\
\hline $75-25-2$ & Bromoform & 0.50 & $\mathrm{U}$ \\
\hline $98-82-8$ & Isopropylbenzene & 0.50 & $\mathrm{U}$ \\
\hline $79-34-5$ & $1,1,2,2$-Tetrachloroethane & 0.50 & $\mathrm{U}$ \\
\hline $541-73-1$ & 1,3-Dichlorobenzene & 0.50 & $\mathrm{U}$ \\
\hline $106-46-7$ & 1,4 -Dichlorobenzene & 0.50 & $\mathrm{U}$ \\
\hline $95-50-1$ & 1,2-Dichlorobenzene & 0.50 & $\mathrm{U}$ \\
\hline $96-12-8$ & 1,2-Dibromo-3-chloropropane & 0.50 & $\mathrm{U}$ \\
\hline $120-82-1$ & $1,2,4$-Trichlorobenzene & 0.50 & $\mathrm{U}$ \\
\hline $87-61-6$ & $1,2,3$-Trichlorobenzene & 0.50 & $\mathrm{U}$ \\
\hline
\end{tabular}


Appendix D:

Time Series Diagrams for Selected Parameters at IM Monitoring Points 

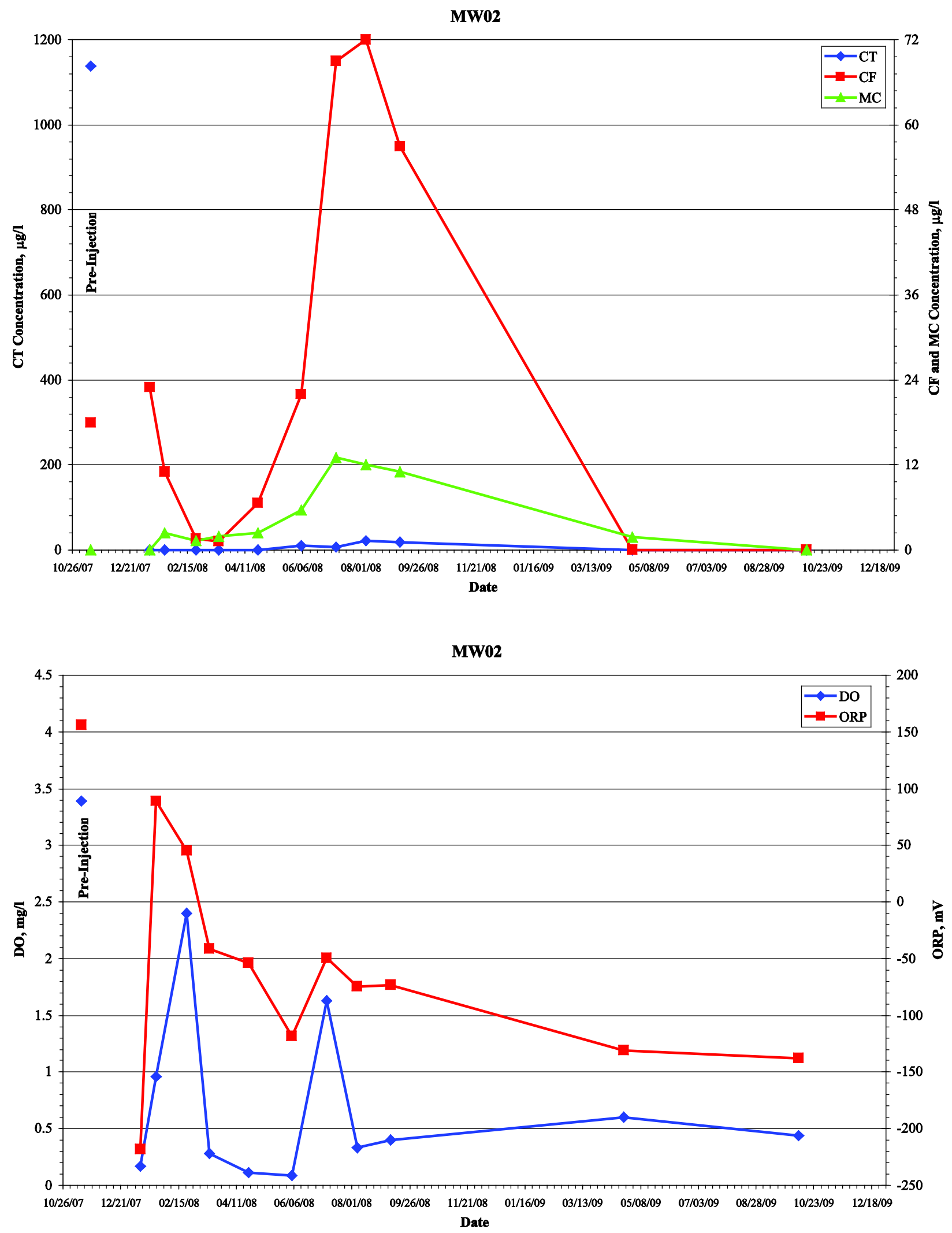

FIGURE D.1 Analytical results for VOCs, DO, and ORP in groundwater samples collected at location MW02, November 2007 to October 2009. 

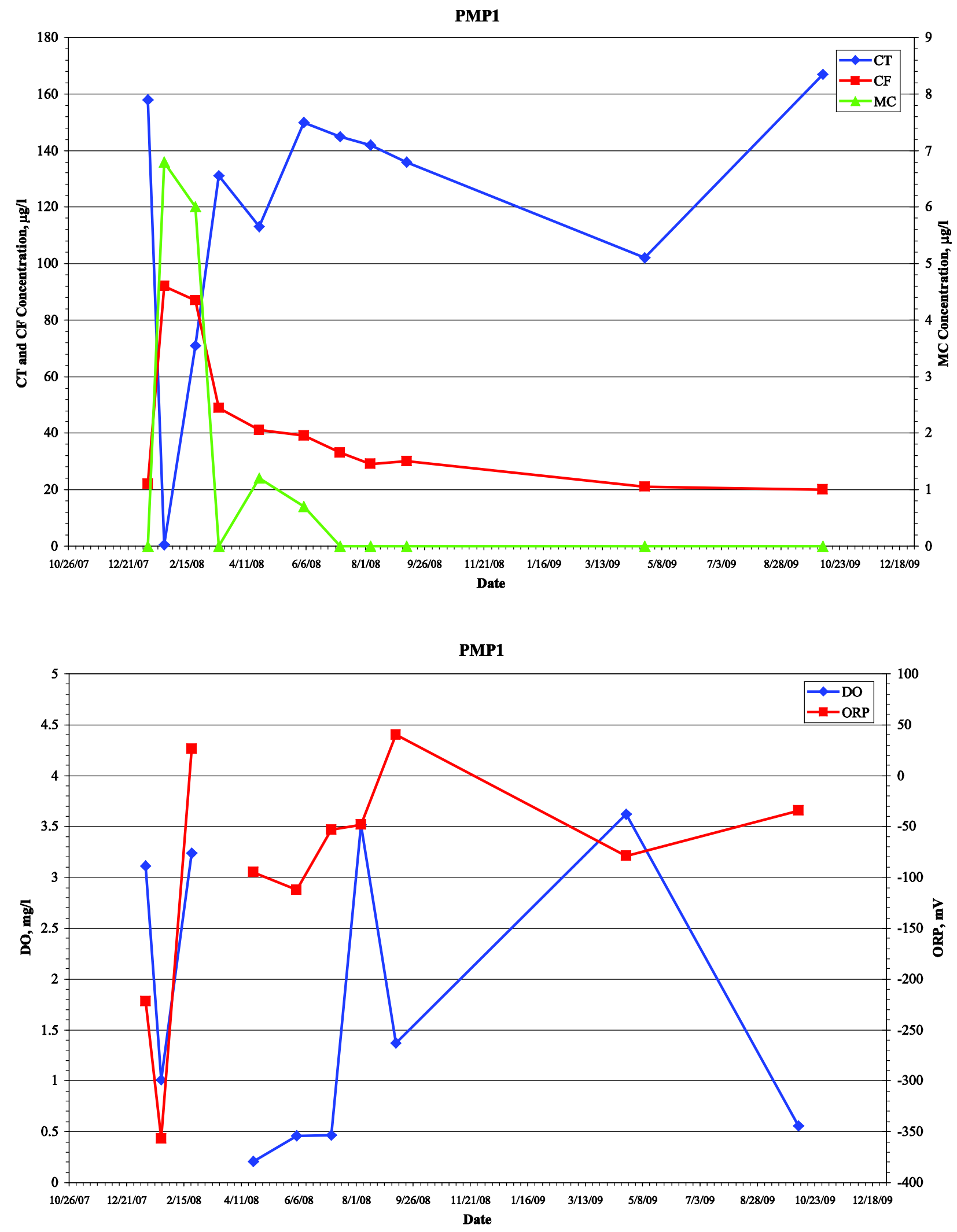

FIGURE D.2 Analytical results for VOCs, DO, and ORP in groundwater samples collected at location PMP1, January 2008 to October 2009. 
PSB2-PMP2

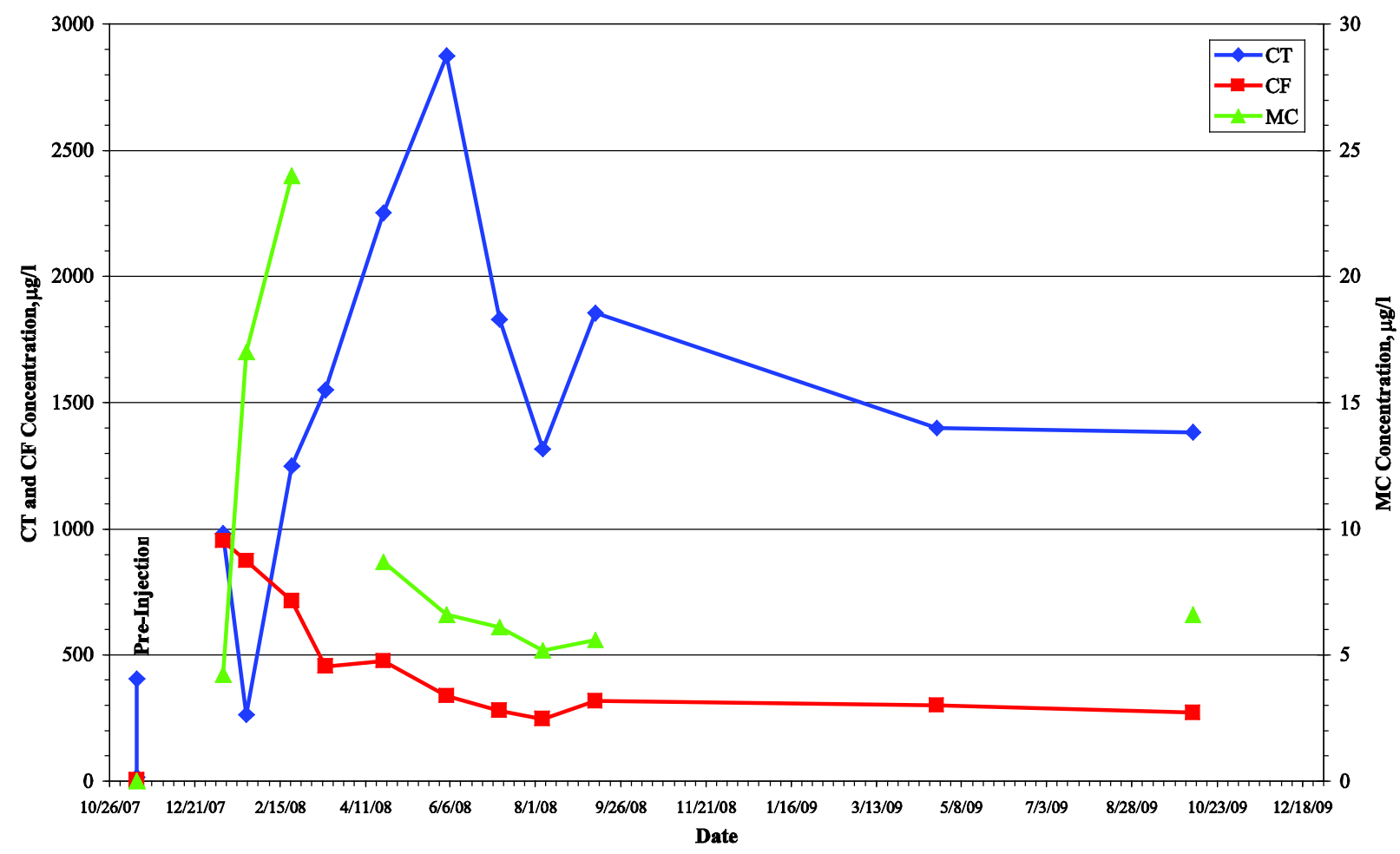

PSB2-PMP2

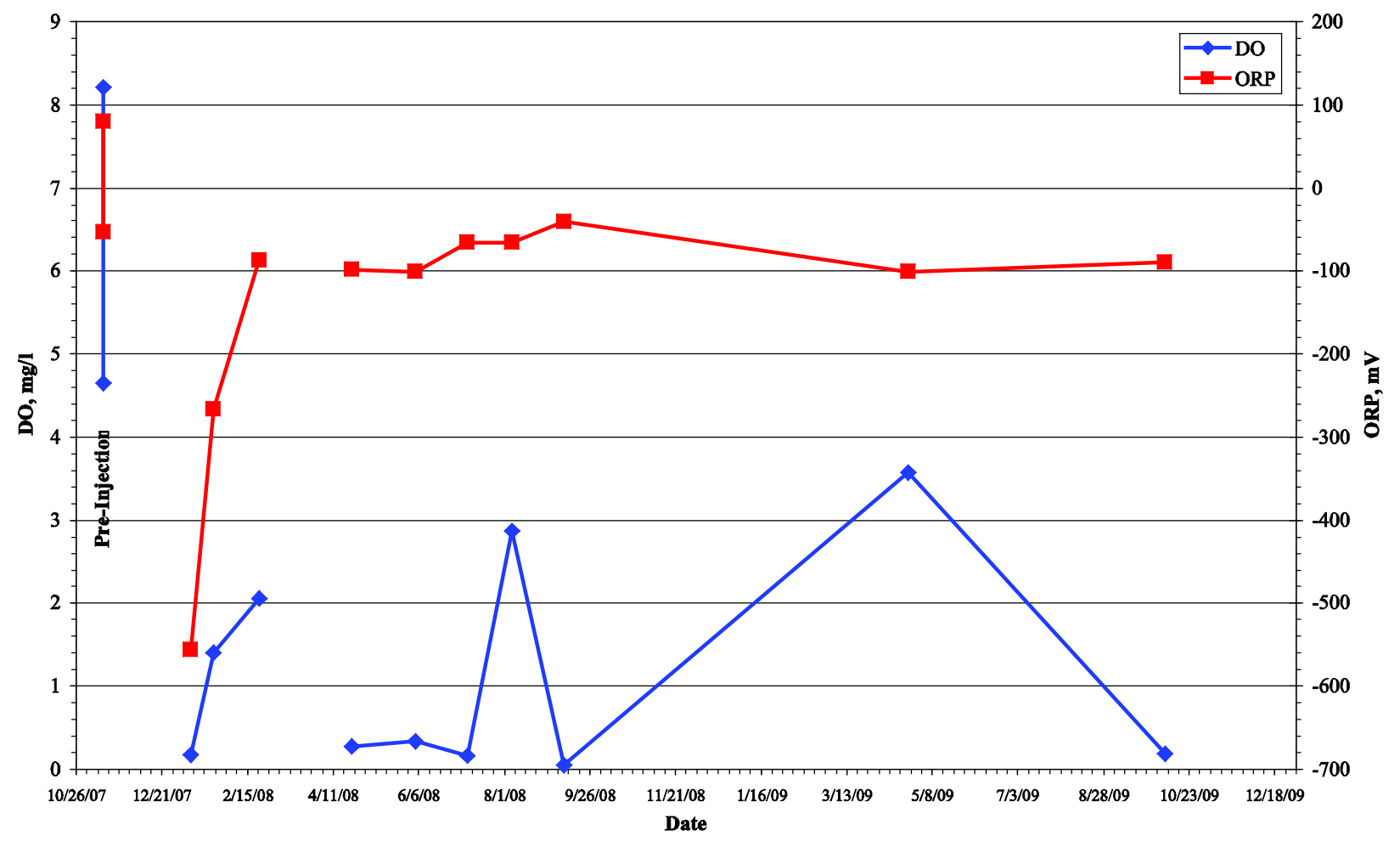

FIGURE D.3 Analytical results for VOCs, DO, and ORP in groundwater samples collected at locations PSB2 and PMP2, November 2007 to October 2009. 
PSB3-PMP3

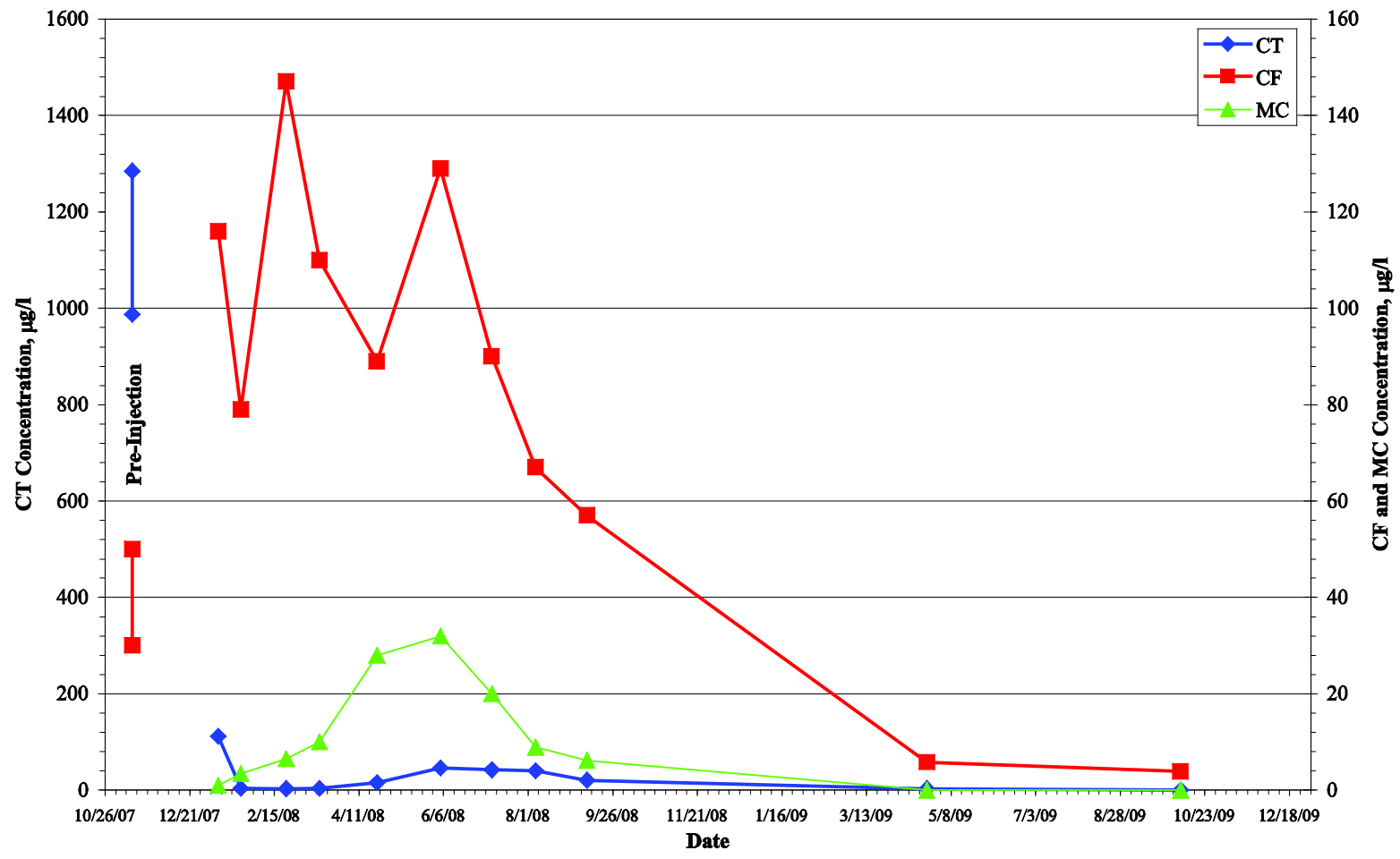

PSB3-PMP3

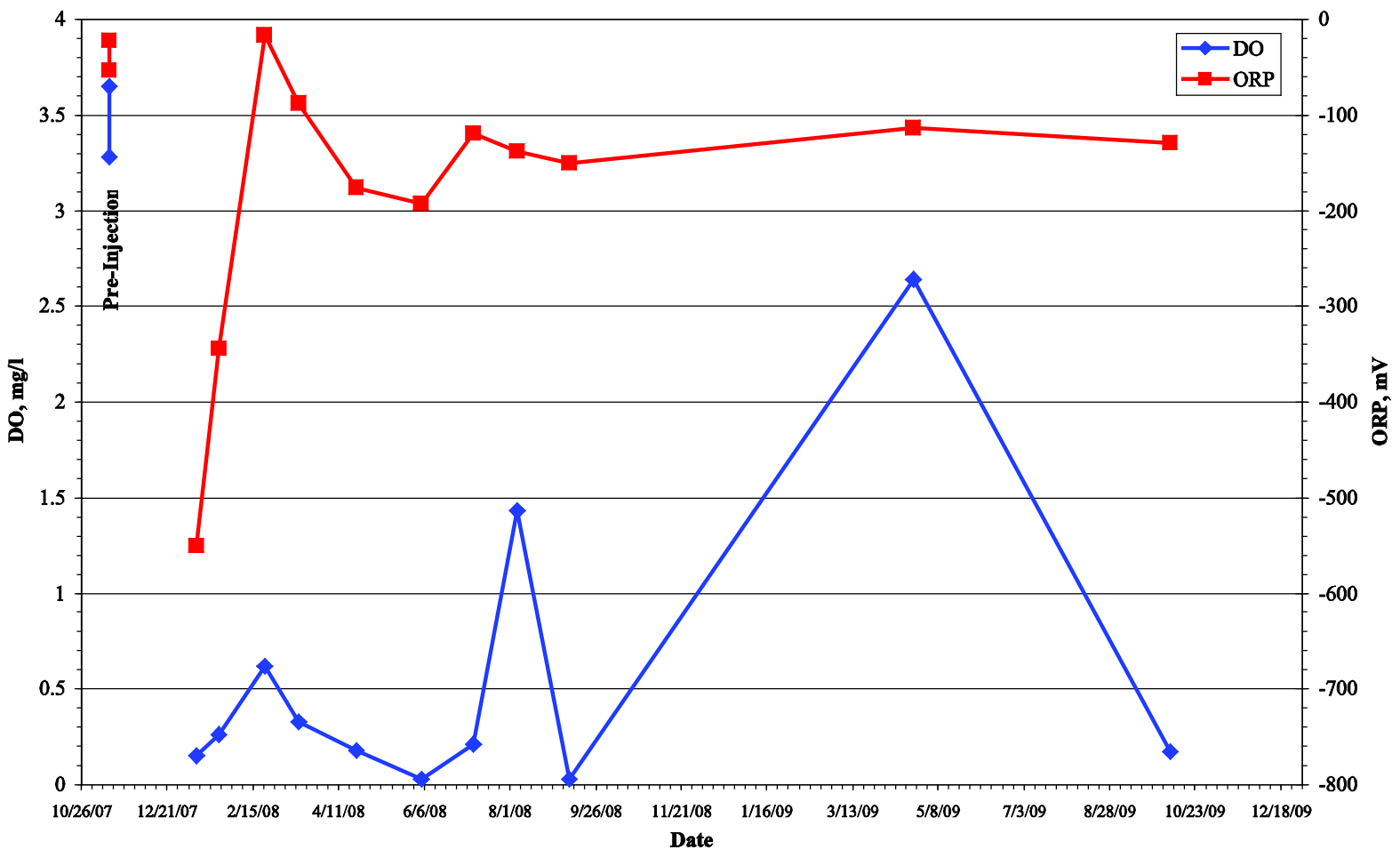

FIGURE D.4 Analytical results for VOCs, DO, and ORP in groundwater samples collected at locations PSB3 and PMP3, November 2007 to October 2009. 
PMP4

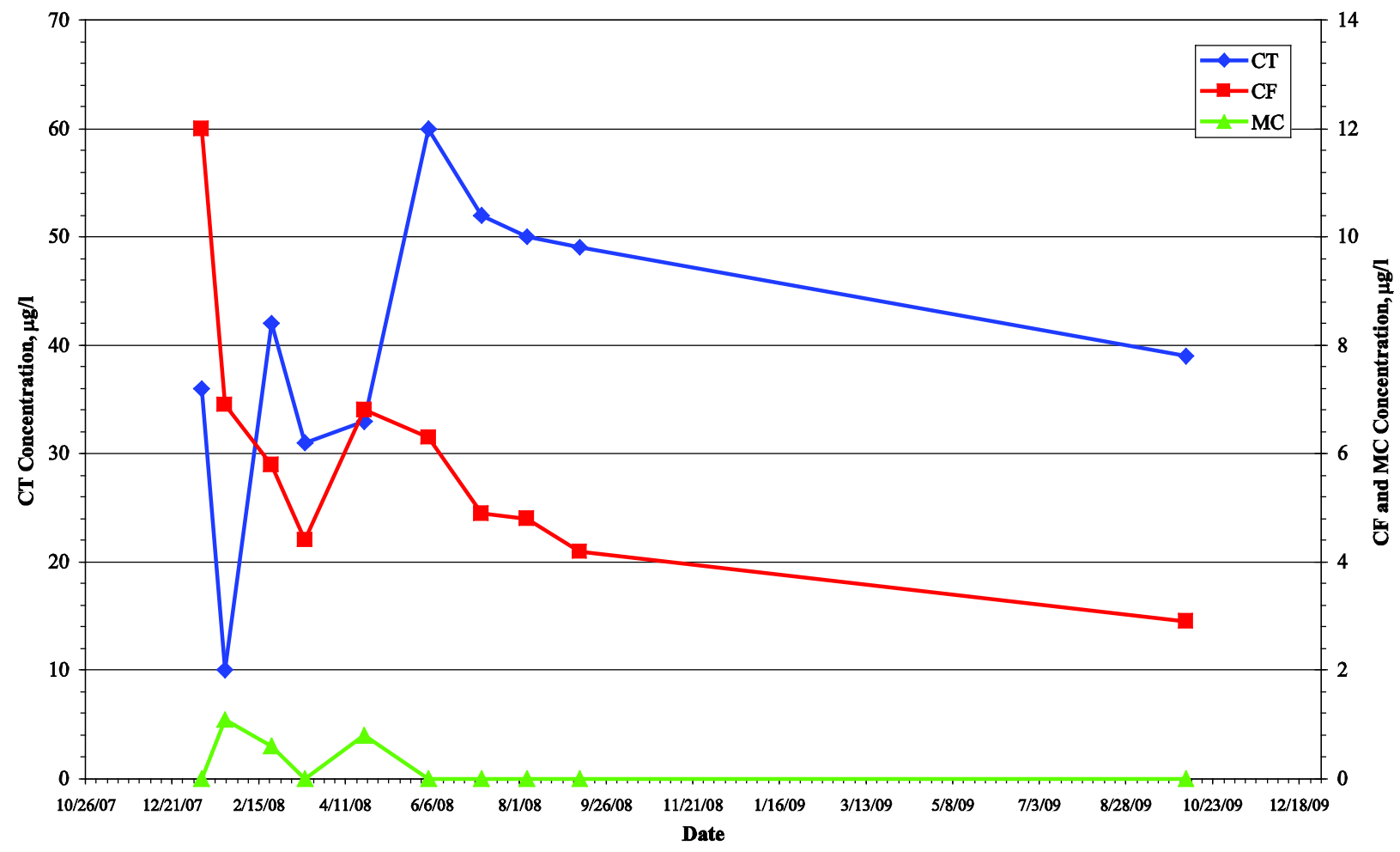

PMP4

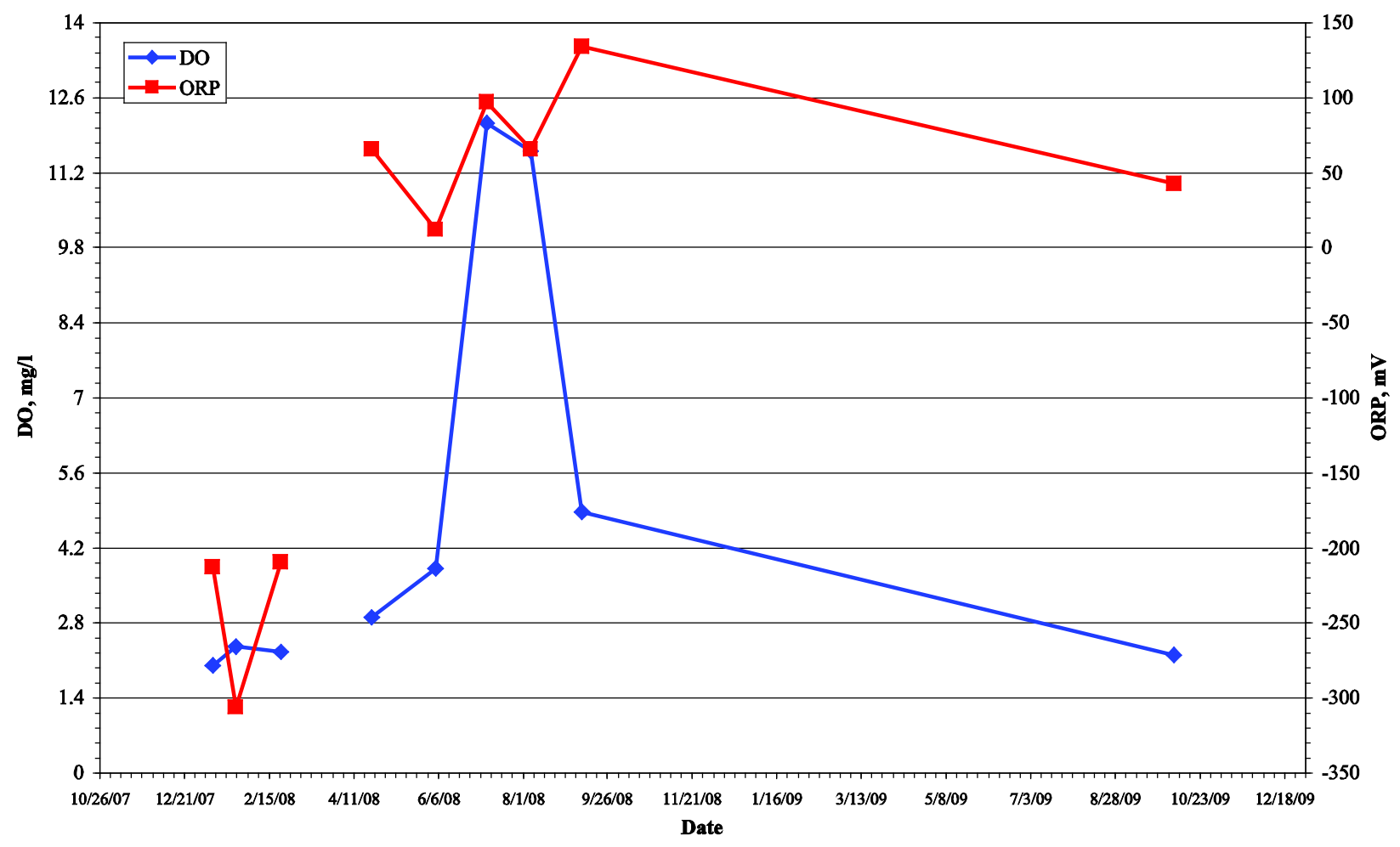

FIGURE D.5 Analytical results for VOCs, DO, and ORP in groundwater samples collected at location PMP4, January 2008 to October 2009. 
PSB5-PMP5

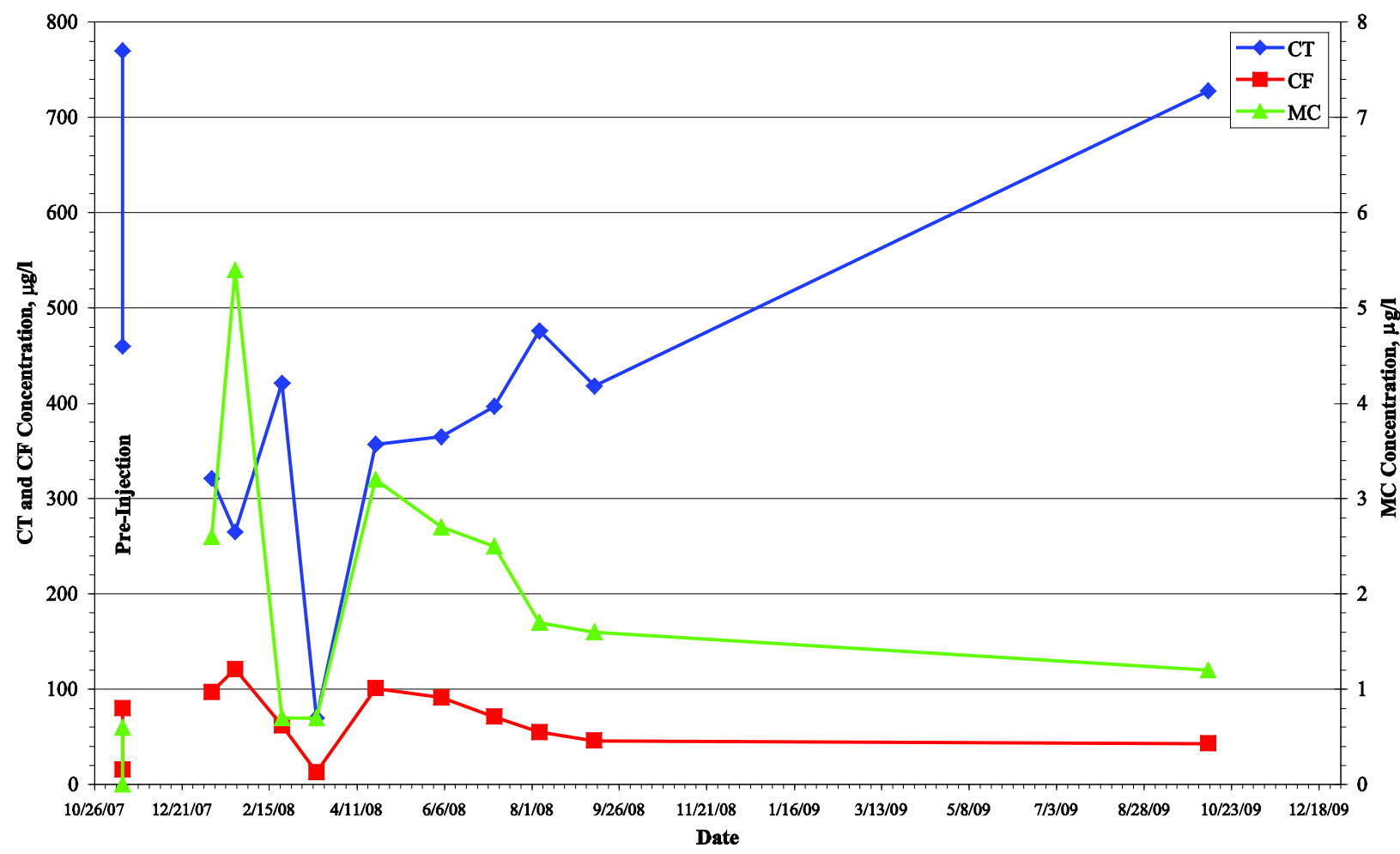

PSB5-PMP5

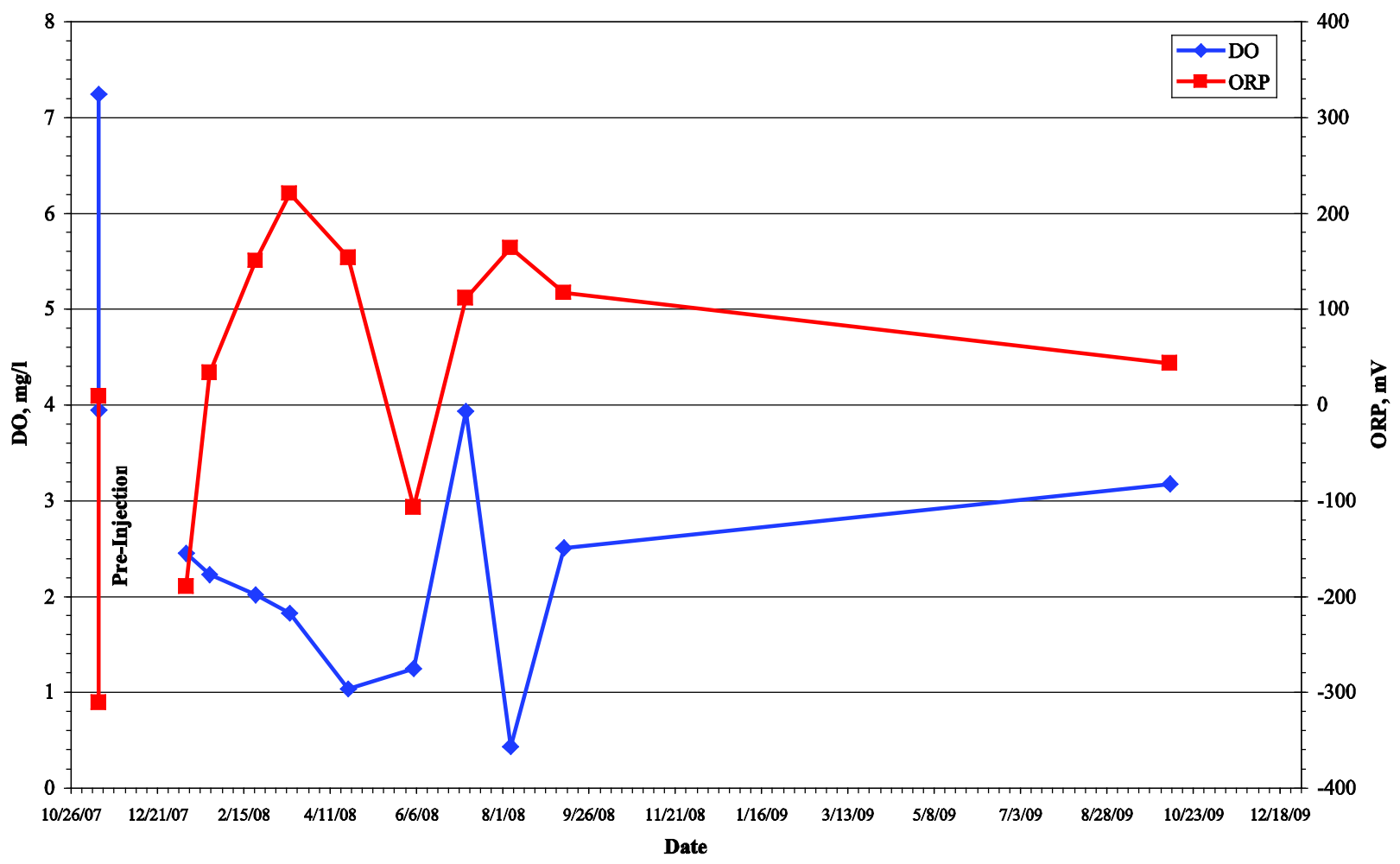

FIGURE D.6 Analytical results for VOCs, DO, and ORP in groundwater samples collected at locations PSB5 and PMP5, November 2007 to October 2009. 
PSB6-PMP6

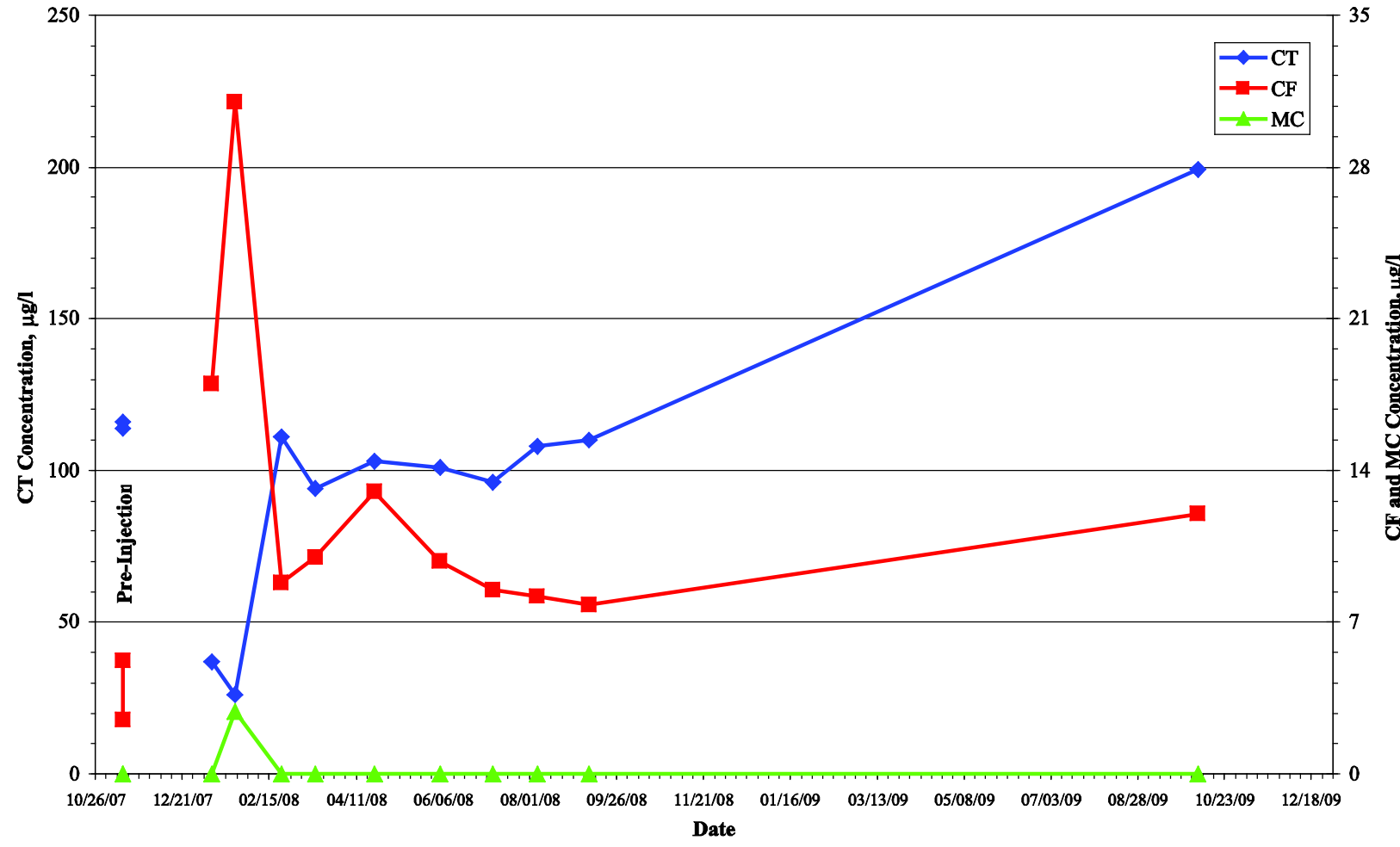

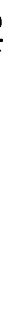

PSB6-PMP6

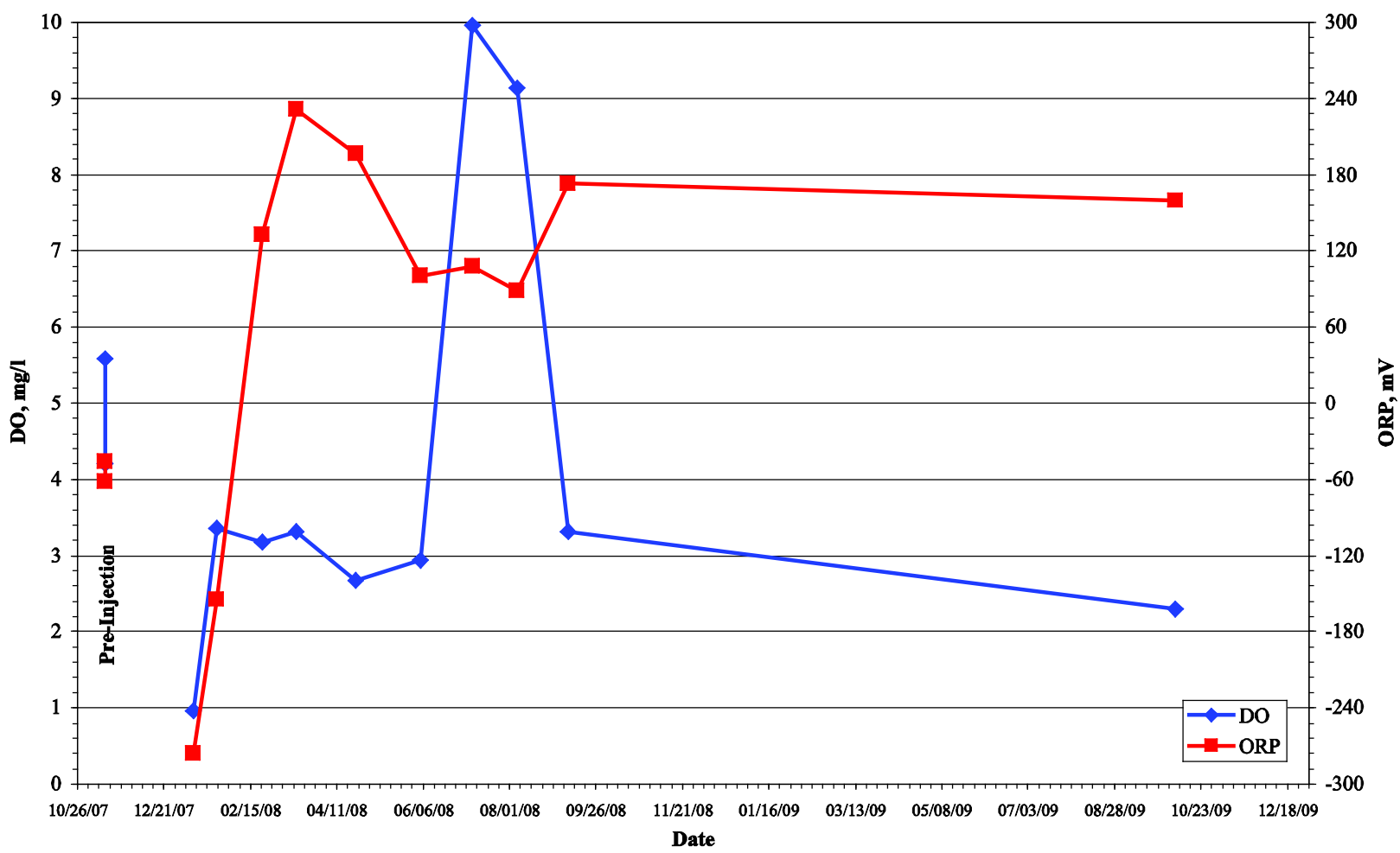

FIGURE D.7 Analytical results for VOCs, DO, and ORP in groundwater samples collected at locations PSB6 and PMP6, November 2007 to October 2009. 
PSB7-PMP7

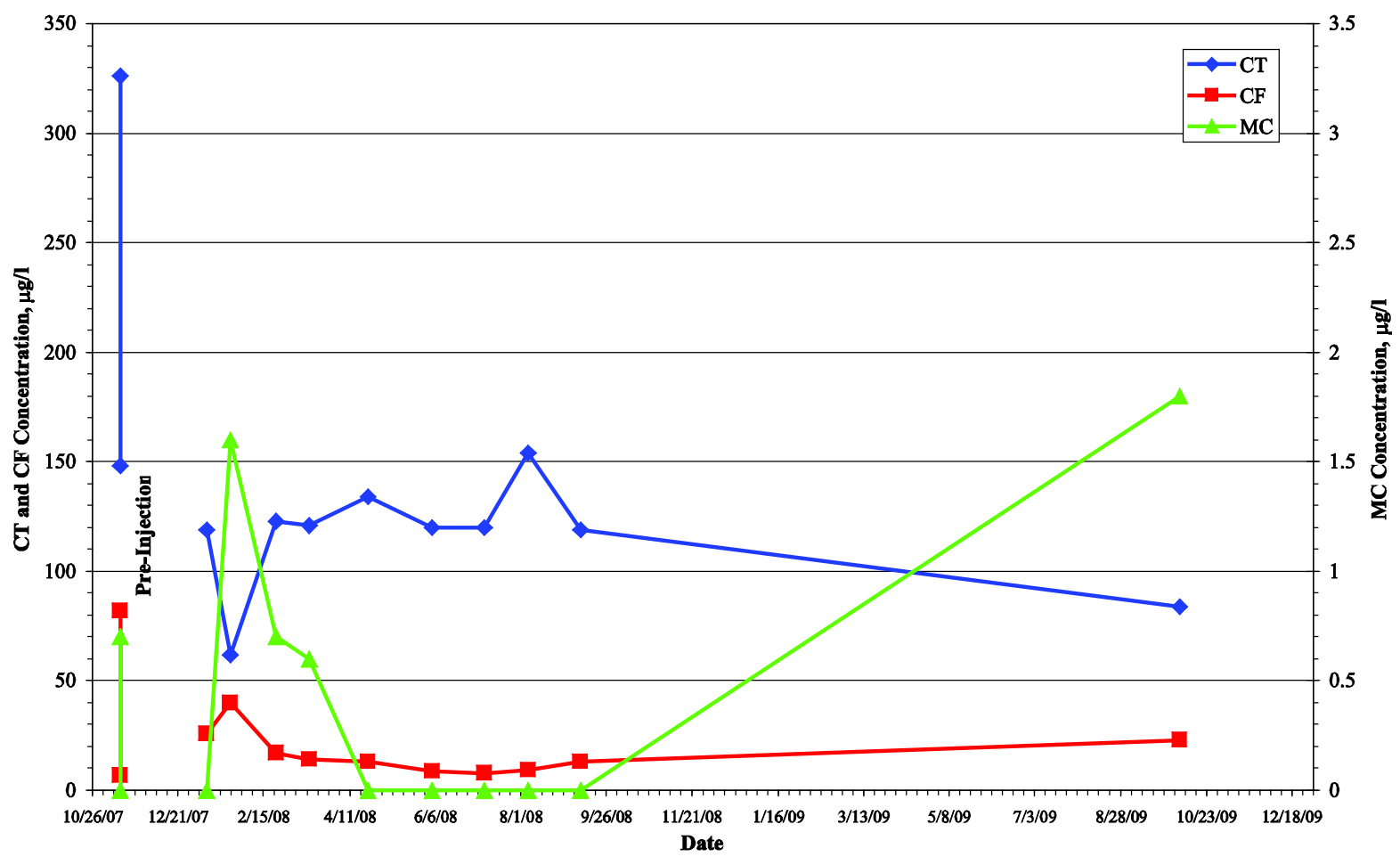

PSB7-PMP7

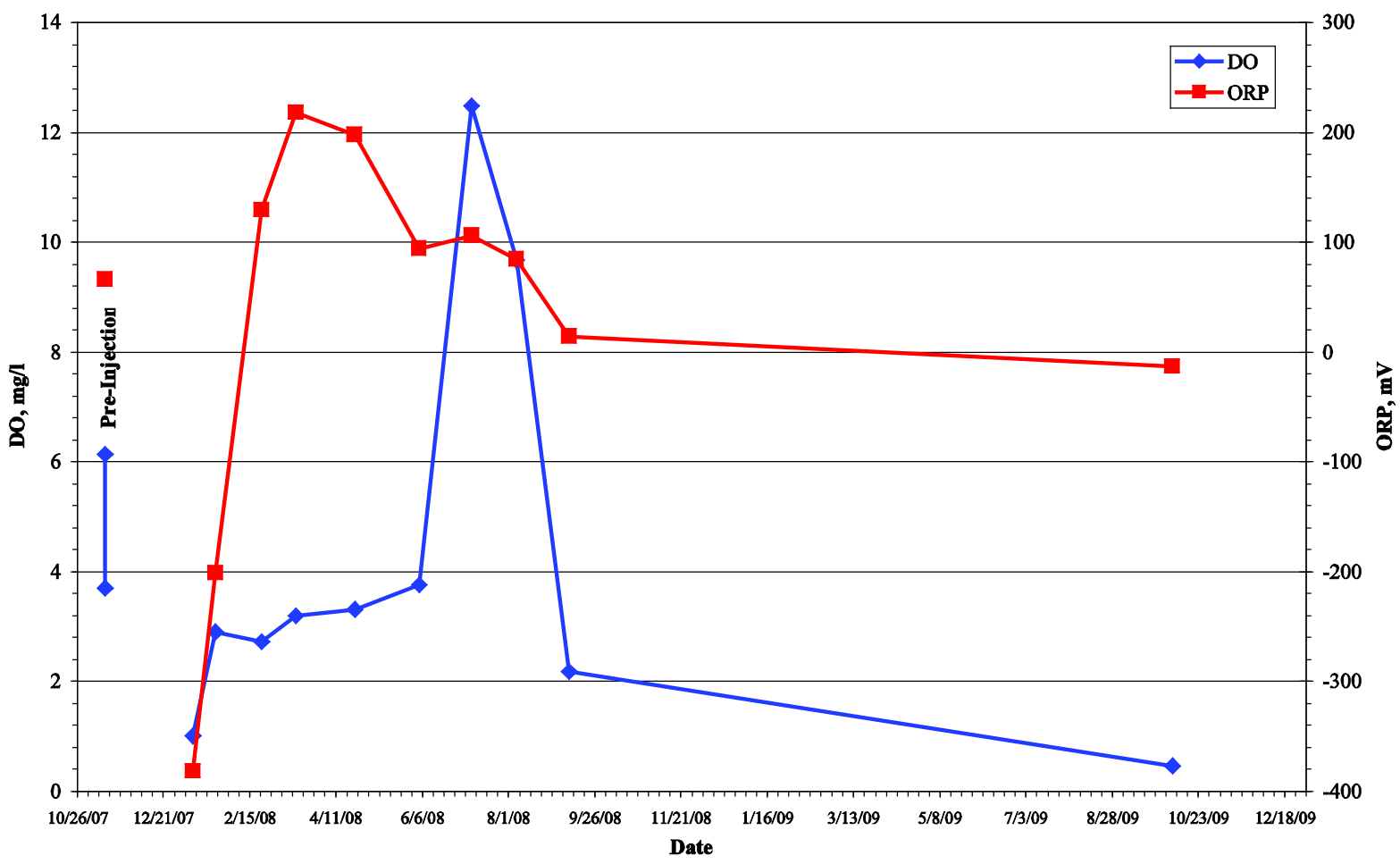

FIGURE D.8 Analytical results for VOCs, DO, and ORP in groundwater samples collected at locations PSB7 and PMP7, November 2007 to October 2009. 
PSB8-PMP8
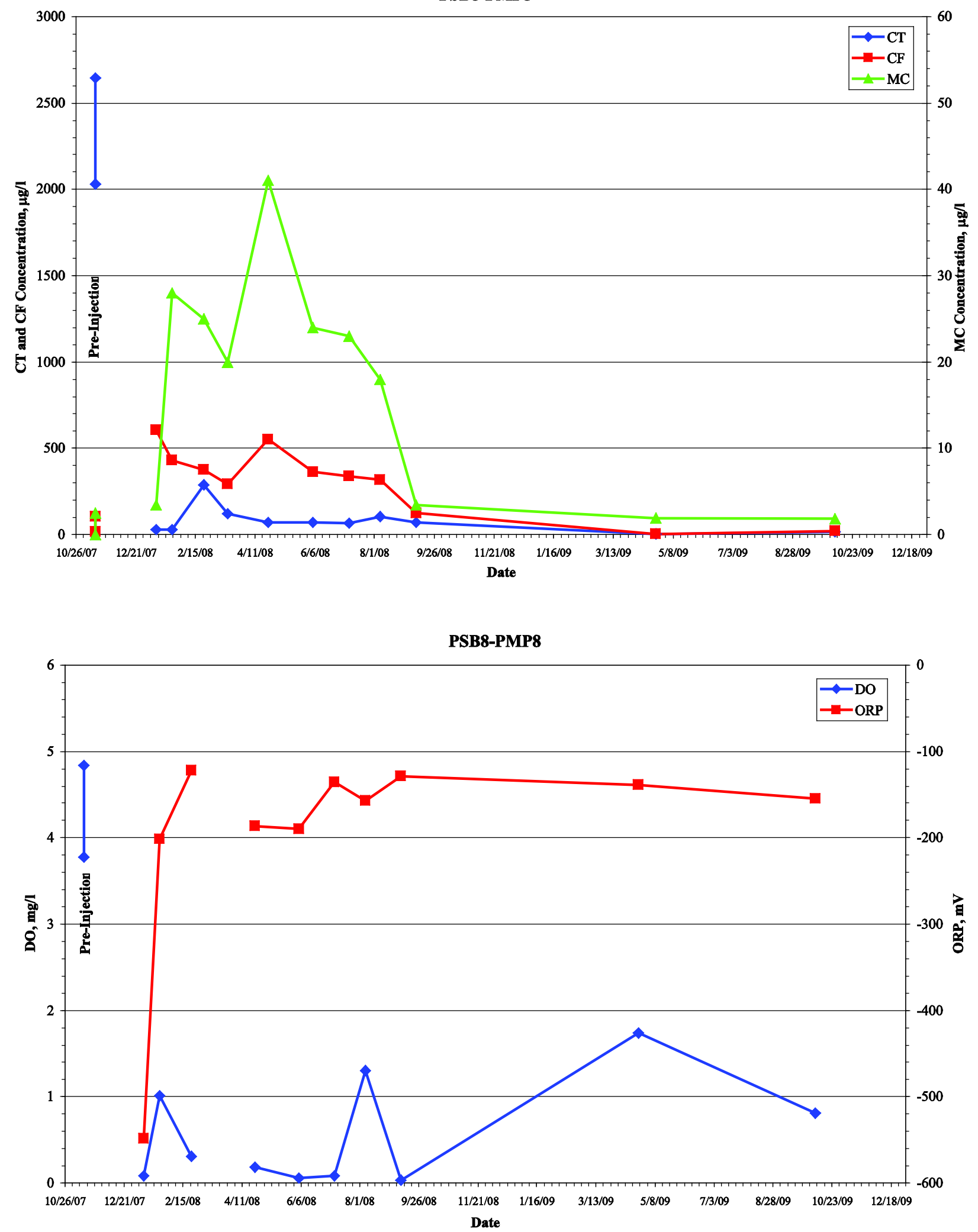

FIGURE D.9 Analytical results for VOCs, DO, and ORP in groundwater samples collected at locations PSB8 and PMP8, November 2007 to October 2009. 
PSB9-PMP9

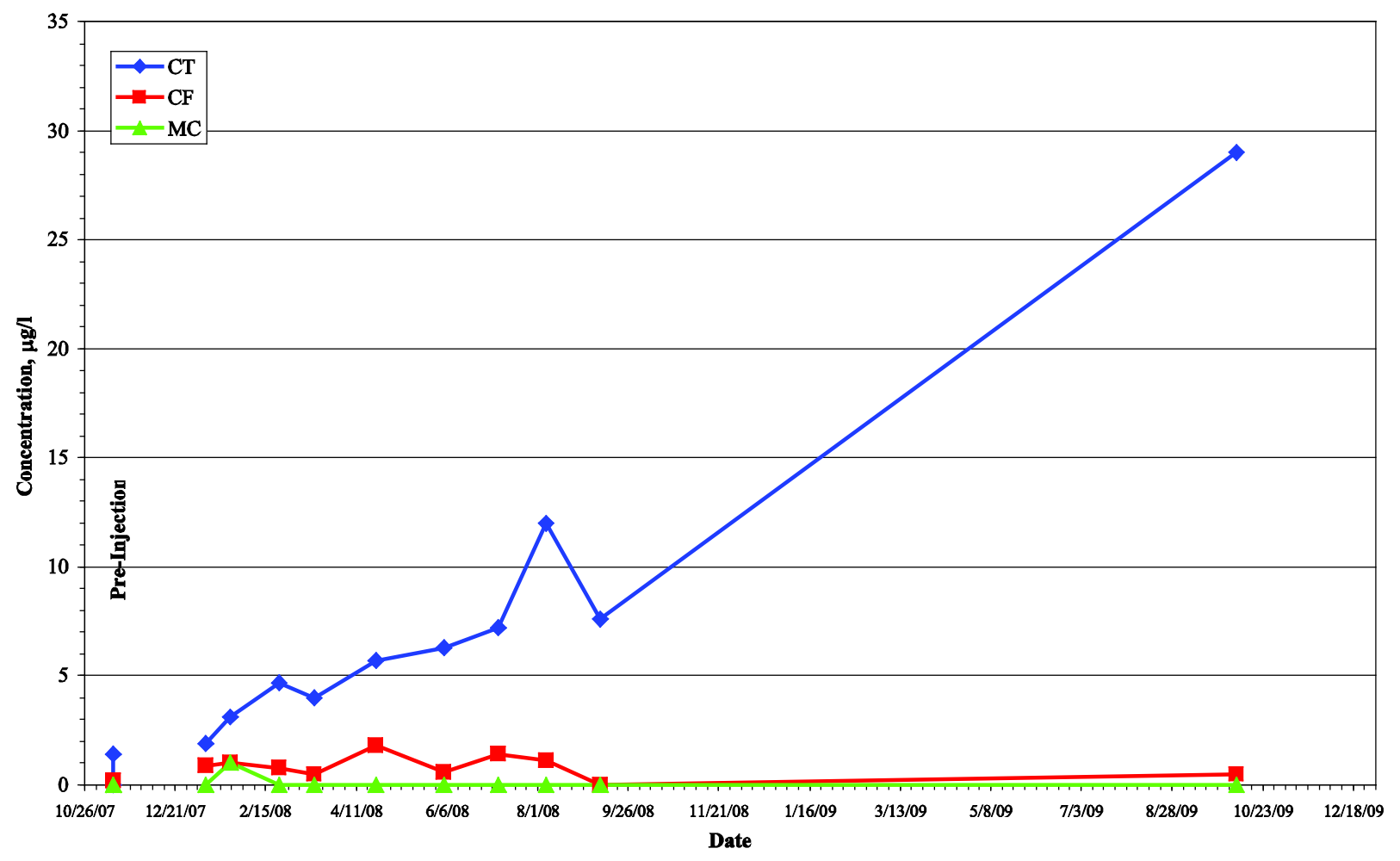

PSB9-PMP9

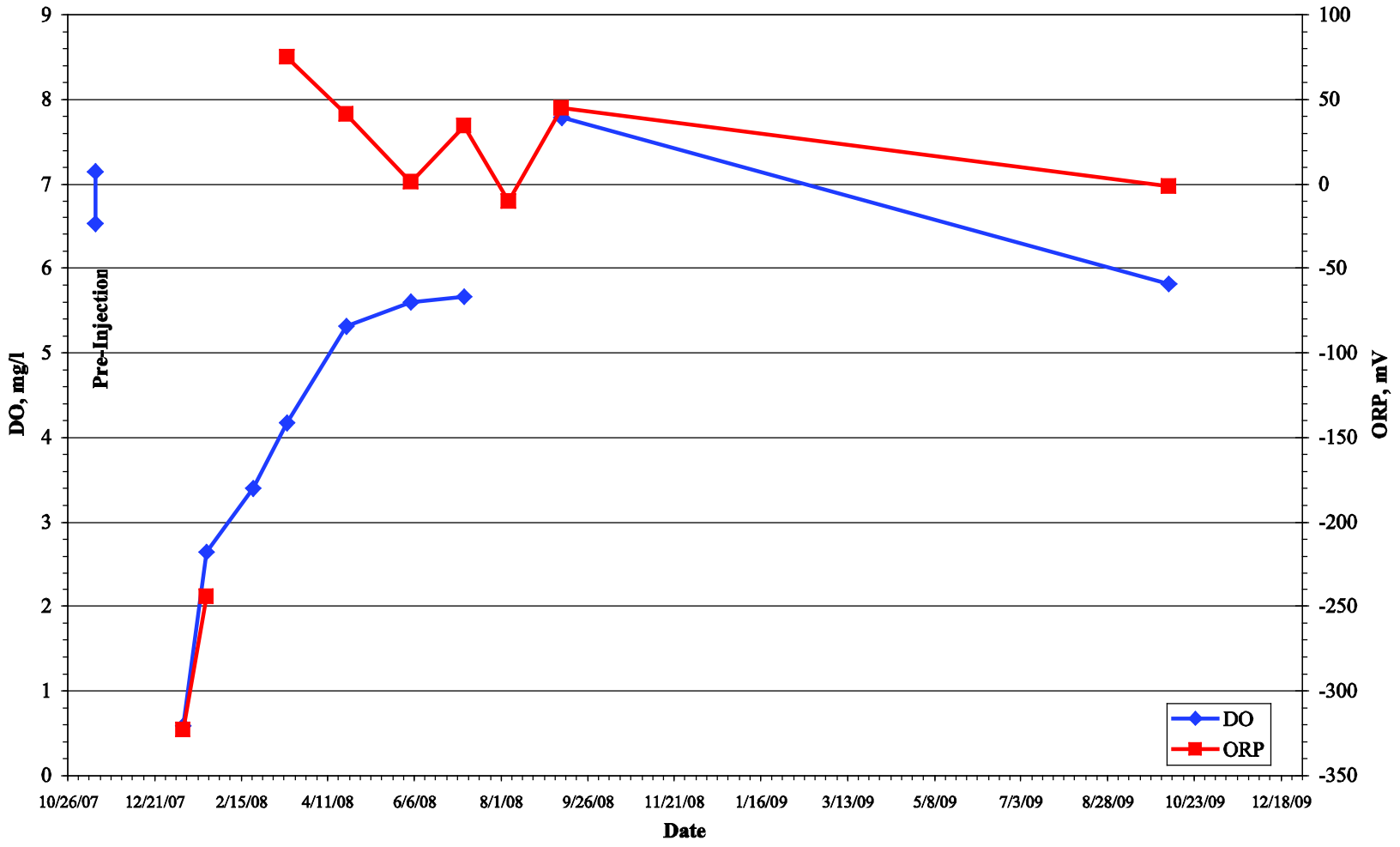

FIGURE D.10 Analytical results for VOCs, DO, and ORP in groundwater samples collected at locations PSB9 and PMP9, November 2007 to October 2009. 
Argonne

\section{Environmental Science Division}

Argonne National Laboratory

9700 South Cass Avenue, Bldg. 203

Argonne, IL 60439-4843

www.anl.gov 